\author{
UNIVERSIDADE DE SÃO PAULO \\ FACULDADE DE FILOSOFIA, LETRAS E CIÊNCIAS HUMANAS \\ DEPARTAMENTO DE HISTÓRIA \\ PROGRAMA DE PÓS-GRADUAÇÃO EM HISTÓRIA SOCIAL
}

História e ressignificação: Joana d'Arc e a historiografia francesa da primeira metade do século XIX

FLÁVIA APARECIDA AMARAL

São Paulo

2012 


\author{
UNIVERSIDADE DE SÃO PAULO \\ FACULDADE DE FILOSOFIA, LETRAS E CIÊNCIAS HUMANAS \\ DEPARTAMENTO DE HISTÓRIA \\ PROGRAMA DE PÓS-GRADUAÇÃO EM HISTÓRIA SOCIAL
}

\title{
História e ressignificação: Joana d'Arc e a historiografia francesa da primeira metade do século XIX
}

Tese apresentada ao Programa de PósGraduação do Departamento de História da Faculdade de Filosofia, Letras e Ciências Humanas da Universidade de São Paulo, como parte dos requisitos necessários à obtenção do título de Doutora em História.

\footnotetext{
Área de concentração: História Social

Orientador: Prof. Dr. Marcelo Cândido da Silva
}

São Paulo 
À Shri Mataji Nirmala Devi À Shri Durga Mata Jagadamba 


\section{AGRADECIMENTOS}

Professor Doutor Marcelo Cândido da Silva, meu orientador, por todos os anos de confiança, apoio e por todas as oportunidades acadêmicas que me ofereceu.

Professora Françoise Michaud-Fréjaville e M. Olivier Bouzy, diretor do Centre Jeanne d'Arc em Orléans. Agradeço a receptividade, atenção e generosidade que me proporcionaram não apenas acesso às fontes, mas momentos de intenso aprendizado e de agradável convivência acadêmica.

Centro Federal de Educação Tecnológica de Minas Gerais, em particular ao campus de Divinópolis. Agradeço aos diretores e coordenadores que ao longo dos três anos em que estou nessa instituição deram-me o suporte necessário para o andamento desse trabalho. Obrigada pela compreensão e o apoio.

Aos amigos pelo incentivo, em especial àqueles que colaboraram com suas leituras e ideias como Laura Nogueira, Norma Leles e Ítalo Esteves.

À minha família paulistana Maíra, Maurício, Gaudí e Joana cuja hospitalidade, amor e carinho foram de importância fundamental na concretização desse trabalho.

Aos meus pais por todo sacrifício e prioridade absoluta em relação os meus estudos; agradeço o apoio e base familiar sem os quais esse trabalho não teria sido concluído. 


\section{RESUMO}

A vida da moça, que ainda criança começara a ouvir vozes lhe revelando a missão de libertar a França dos invasores ingleses, que liderou um exército, coroou o seu rei e teve um destino trágico, sendo queimada viva como herege, parece saída de uma obra literária, mas como bem lembra Colette Beaune "Joana d'Arc é provavelmente, a figura de mulher mais documentada de toda a História." Atualmente contam-se 20.000 estátuas públicas, centenas de biografias e peças de teatro, dezenas de filmes, óperas e músicas. Seria possível desvendar as razões para tamanho sucesso? Essa popularidade foi alcançada ao longo de um processo contínuo e homogêneo, ou houve rupturas, sobressaltos e novas atribuições à heroína que possam ser verificados ao longo do tempo? Essa tese discute a importância da primeira metade do século XIX para esse fenômeno. Nesse período a historiografia francesa se esforçou para enquadrar Joana d'Arc, heroína há muito honrada pelo reino da França, nos padrões da sociedade pósrevolucionária. Longe de desqualificá-la como figura incompatível com a modernidade pretendida por aquele país, tal como proposto no contexto revolucionário, Joana foi alçada ao panteão dos heróis nacionais tendo sua imagem amalgamada aos ideais de 1789. Buscamos desvendar o processo que tornou possível a popularização de uma nova Joana d'Arc naquele período, processo intimamente ligado aos valores burgueses então difundidos: a nação, o povo, a pátria, o indivíduo. As novas características atribuídas à Joana correspondiam às expectativas burguesas a partir de um discurso ligado a uma nova visão da História que passou a ser considerada como potencial produtora de verdades e justificativas que embasassem a configuração social que se anunciava.

Palavras-chave: Joana d'Arc; historiografia francesa; século XIX; nacionalismo 


\begin{abstract}
The life of the young lady whose childhood was haunted by the hearing of voices which revealed to her a mission to free France from English invaders, who led an army, crowned her king had a tragic fate and was burned at the stake as a heretic seems to be taken from a literature work. But as Colette Beaune has rightly pointed out "Joan of Arc is probably the most documented woman figure in all World History." It can be numbered about 20,000 public statues, hundreds of biographies and plays, dozens of films, operas and other pieces of music. Would it be possible to unfold the reasons for such an interest in her? The question lies, however, in how quite high popularity was gained. Was it the result of a continuous and homogeneous process or were there interruptions, surprises and new attributions assigned to the heroine that can be verified over time? This thesis discusses the importance of the former half of the nineteenth century to this phenomenon. Throughout this period French historiography struggled to fit Joan of Arc, the heroine overly honored by the kingdom of France, in the patterns of a post-revolutionary society. Far from discrediting her reputation as a figure incompatible with modernity desired by that country, as proposed in the revolutionary context, Joan was elevated to the national pantheon of heroes and had her image amalgamated to the ideals of 1789. It's sought to disclose the process that led to a substantial popularization of a new Joan of Arc at that time, and is intimately connected to bourgeois values disseminated then: nation, people, homeland and individual. New features attributed to Joan met the bourgeoisie expectations through a discourse on a new way of looking at History that turned out to be regarded as a potential producer of truths and justifications to support the social setting that was being announced.
\end{abstract}

Keywords: Joan of Arc; French historiography; nineteenth century; nationalism. 


\section{CONTEÚDO}

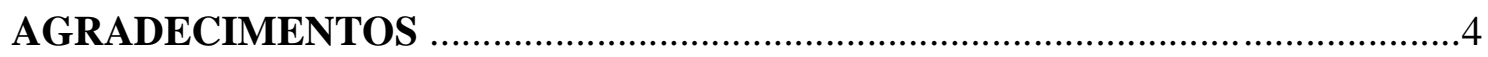

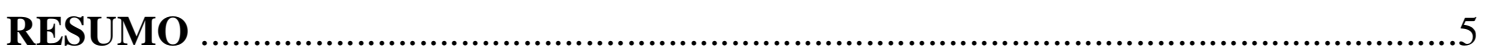

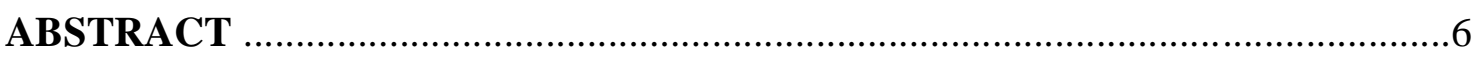

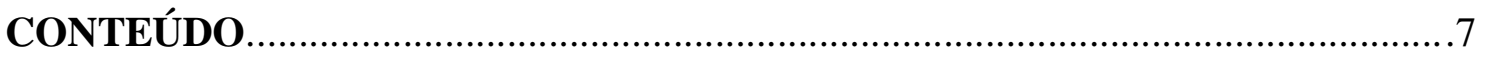

INTRODUÇÃ

CAPÍTULO I - História, Revolução e Ressignificação

1.1 - A História e a Revolução Francesa ........................................................................ 33

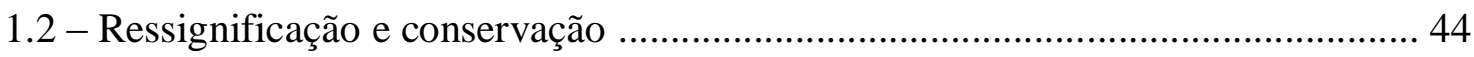

CAPÍTULO II - Entre a biografia e a História Nacional, a epopeia de Joana d'Arc

2.1 - Da necessidade da História da França na vida de Joana d'Arc ............................62

2.2 - Da necessidade da vida de Joana d'Arc na História da França .............................73

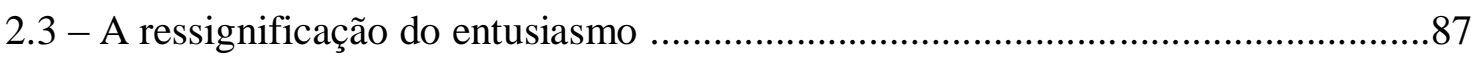

2.3.1 - A origem iluminista da discussão sobre o entusiasmo .................................... 108

CAPÍTULO III - Os elementos da ressignificação: o povo e a nação

3.1 - Temas centrais de uma historiografia "liberal" e "romântica" .......................... 126

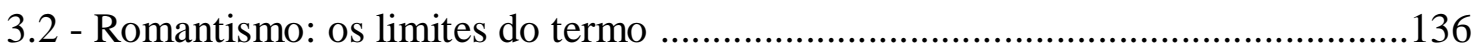

3.3 - Identificando e construindo o povo e a nação ....................................................141

3.3.1 - Domrémy - a fronteira como local de peregrinação nacional ...........................151 
CAPÍTULO IV - A História científica e a "verdade" sobre Joana d'Arc

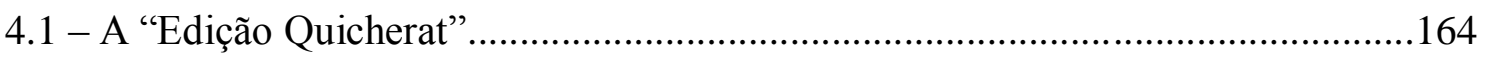

4.2 - O século XIX e a originalidade da História Científica ......................................172

4.3 - A construção de uma verdade nacional e política ............................................175

4.4 - A História Científica a serviço da Nação .............................................................178

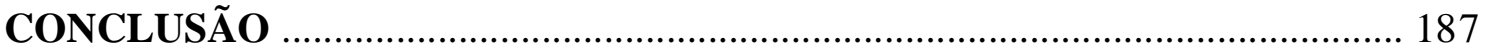

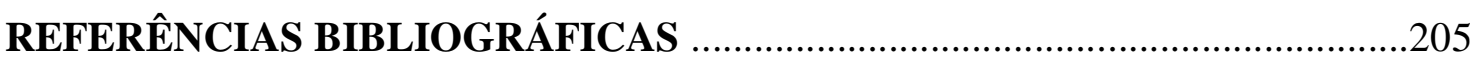




\section{INTRODUÇÃO}

Sexta-feira, seis de janeiro de 2012, Domrémy-la-Pucelle. Pela primeira vez em seu mandato, o presidente da França Nicolas Sarkozy preside uma cerimônia oficial em homenagem à Joana d'Arc. Ele se dirigiu a essa pequena cidade para festejar o aniversário da heroína na própria casa em que ela nasceu. O fato causou espanto, uma vez que o presidente nunca havia participado, como seus antecessores - Giscard d'Estaing, François Mitterrand e Jacques Chirac - nem ao menos das tradicionais "Festas Joânicas" que acontecem todos os anos no mês de maio em Orléans para comemorar a libertação da cidade por Joana d'Arc em 1429.

Sábado, sete de janeiro de 2012, Paris. A "Frente Nacional" lota a Place des Pyramides em comemoração ao $600^{\circ}$ aniversário de Joana d'Arc. Decidiram fazer a festa um dia depois da data do nascimento de Joana, certamente para não haver concorrência com a cerimônia presidencial em Domrémy. Jean-Marie le Pen discursa diante da estátua da Donzela ${ }^{1}$ reafirmando os ideais do seu partido e criticando a inédita homenagem de Sarcozy à heroína francesa.

E assim, por no mínimo três semanas, Joana d'Arc se tornou personagem frequente na campanha presidencial francesa de 2012. A troca de farpas entre os presidenciáveis, Marine le Pen e Nicolas Sarkozy, estampavam as chamadas dos

\footnotetext{
${ }^{1}$ A própria Joana, em sua vida pública, adota para si a denominação La Pucelle, forma que aparecerá em inúmeros documentos desde então. Nas fontes contemporâneas e nos processos seu nome aparece simplesmente como "Jehanne", "Jehanne, la Pucelle" ou "Jehanne Darc". O uso do apóstrofo em seu nome conforme ficou consagrado - "d'Arc" - é considerado anacrônico por vários autores, pois como observou Marina Warner esse caractere só aparece nos nomes das famílias francesas a partir do Renascimento. No entanto, optamos por manter em nosso texto a forma mais adotada em português, Joana d'Arc, usando de forma intercambiante o epíteto "Donzela". Cf. WARNER, Marina. Joan of Arc. The image of female heroism. New York: Alfred A. Knopf, 1981.
} 
principais veículos de comunicação franceses na mídia escrita e eletrônica. Acusações de oportunismo e uso indevido da imagem de Joana partiam de todas as partes provocando reações em ambos os candidatos.

É de espantosa atualidade a mobilização em torno de Joana d'Arc, o personagem feminino mais conhecido da História Francesa. A vida da moça, que ainda criança começara a ouvir vozes lhe revelando a missão de libertar a França dos invasores ingleses, que liderou um exército, coroou o seu rei e teve um destino trágico, sendo queimada viva como herege, parece saída de uma obra literária, mas como bem lembra Colette Beaune "Joana d'Arc é provavelmente, a figura de mulher mais documentada de toda a História ${ }^{2}$." Toda essa improvável trajetória chamou a atenção ainda antes de sua morte.

Já em 1429 Christine de Pisan toma partido da Donzela ao compor Ditié de Jeanne d'Arc, obra em que a caracteriza como "Donzela enviada por Deus." ${ }^{3}$ Durante sua vida ela aparece também em obras que questionam sua boa fé e conduta como testemunha o Journal d'un Bourgeois de Paris à la fin de la Guerre de Cent Ans ${ }^{4}$. Após sua morte surgiram falsas "Joanas" e rumores de que, na verdade, a Donzela era uma filha bastarda do rei. Sua história vai ser narrada em muitas obras dos séculos XVI, XVII e XVIII sendo no século XIX o ápice do sucesso editorial de Joana d'Arc. Nesse

\footnotetext{
${ }^{2}$ BEAUNE, Colette. Joana d'Arc. Trad. Marcos Flamínio Peres. São Paulo: Globo, 2006. p. 15.

3 "Tu, Johanne, de bonne heure née,

Benoist soit cil qui te créa!

Pucelle de Dieu ordonnée,

En qui le Saint-Esprit réa

Sa grant grâce et qui ot et a

Toute largesse de hault don,

N'onc requeste ne te véa

Que te rendront assez guerdon ?"

PISAN, C. Ditié de Jehanne d'Arc. Ed. Angus J. Kennedy and KennethVarty.Oxford: Society for the Study of Mediaeval Languages and Literature, 1977. 22a estrofe. Grifo nosso.

4 "La dame Jeanne [...] a trompé le peuple, a fait idolâtrer le simple peuple, car par sa fausse hypocrisie, ils la suivaient comme sainte pucelle”. Journal d'un bourgeois de Paris. Editado por Colette Beaune, Paris, 1990, p. 292.
} 
período ela se torna figura essencial nas Histoires de France e na segunda metade desse século a ideia de canonização ganha grande fôlego a partir da atuação do Monsenhor Dupanloup, Bispo de Orléans. Seus esforços foram bem sucedidos; Joana é declarada "Beata" em 1909, "Santa" em 1920 e em 1922 ela é canonizada como a "Segunda Padroeira da França."

Durante a Segunda Guerra Mundial o governo de Vichy tenta associar Joana d'Arc aos ideais que o sustentavam e em fins do século XX e início do XXI a extrema direita francesa reclama seus "direitos" sobre a heroína.

Atualmente contam-se aproximadamente 20.000 estátuas públicas, 800 biografias históricas, 52 filmes ${ }^{5}$, centenas de peças de teatro, romances, músicas, uma ópera composta por Verdi "Giovana d'Arco", além das obras inacabadas de Tchaikovski e Ravel. Trata-se de um personagem cuja trajetória interessou às mais diversas áreas, desde a própria História, passando pela Psicologia e Dramaturgia. Sua vida suscitou a curiosidade não apenas das mais variadas áreas do conhecimento, como também de estudos ditos espiritualistas ${ }^{6}$.

Seria possível desvendar as razões para tamanho sucesso? Essa popularidade foi alcançada ao longo de um processo contínuo e homogêneo, ou houve rupturas, sobressaltos e novas atribuições à heroína que possam ser verificados ao longo do tempo? Em meio às mais diversas e pertinentes questões que podem ser colocadas um

\footnotetext{
${ }^{5}$ O primeiro filme sobre Joana d'Arc foi feito em 1898 por Georges Hatot e se chama "Jeanne d'Arc". Cf. BOUZY, Olivier, CONTAMINE, Philippe. \& HÉLARY, Xavier. Jeanne d'Arc: Histoire et dictionnaire. Bouquins, 2012.

${ }^{6}$ Dentre as inúmeras obras que contemplam esses diferentes temas, citamos algumas. No teatro: "Die Jungfrau von Orléans", de Schiller (1801); O mistério da caridade de Joana d'Arc (1910), de Charles Péguy. Dentre os escritos espíritas, destacam-se: Joana D'arc, por ela mesma (livro psicografado em 1855 pela médium Ermance Dufaux); Joana d'Arc - Judas Iscariotes, de Marcelo de Barros (1996 e 2000). No Brasil, o nome de Joana d'Arc é usado para nomear escolas e universidades (Faculdade Joana $d^{\prime} A r c$ ) e até um Centro de Convivência de pessoas HIV positivo (CeCon Joana D’Arc).
} 
fato chama a atenção. Como dissemos houve um interesse especial do século XIX por Joana d'Arc. Foi a sociedade oitocentista francesa que a aproximou dos ideais e demandas do Terceiro Estado e aí encontramos um elemento original associado a uma heroína até então monarquista por excelência, marcando uma mudança fundamental naquilo que o personagem significava para a história francesa até então.

Ao nos depararmos com uma nova imagem atribuída à Joana d'Arc no século XIX uma questão fundamental se coloca: que fenômeno poderia ter deflagrado esse processo? Teria a Revolução Francesa alguma influência nesse contexto? Essas questões motivaram o nosso trabalho. Assim propomos uma análise sobre a atribuição de um novo significado à história de Joana d'Arc no século XIX, partindo da constatação do aumento numérico de obras dedicadas a ela nesse período e tendo em vista que:

1- tais textos foram produzidos em um ambiente intelectual politicamente influenciado por discussões sobre o significado e o alcance da Revolução Francesa e sobre o papel do Terceiro Estado;

2- essas obras foram escritas, em sua maioria, por autores considerados como representantes tanto da chamada "Revolução Historiográfica" da década de 1820, quanto do "movimento romântico";

3- os biógrafos de Joana d'Arc foram, na maior parte dos casos, homens de posição política clara, que muitas vezes tiveram não apenas funções de liderança em institutos de pesquisa e ensino da França naquele período, como também ocuparam postos políticos importantes; 
4- e, finalmente, esses textos foram produzidos no momento em que se costuma localizar o nascimento da História como um campo de conhecimento autônomo, que se queria científico, enfim, no momento que Hyden White define como o de "profissionalização da história"7.

Não sendo possível afirmar o caráter apenas coincidente desses fatos, pretendese levá-los em conta para acessar a teia de relações que os ligam à constituição de Joana d'Arc como símbolo nacional da França. Optamos por privilegiar a primeira metade do século XIX por entender que foi esse o momento em que se lançaram as bases para uma nova interpretação da história de Joana d'Arc, momento esse que tem sido negligenciado pela historiografia joânica de um modo geral.

A história de Joana d'Arc é estudada pelos medievalistas sobretudo a partir de seu processo de condenação, do processo de anulação da condenação e das crônicas históricas nas quais ela é mencionada ${ }^{8}$. Se comparados à quantidade de obras dedicadas à Joana que a estudam em seu contexto, poucas são as análises que se referem à constituição dessa personagem como símbolo da história nacional francesa, não somente a partir de uma constatação desse fato, mas buscando perceber seus efeitos na própria ideia e análise do período medieval que se forjou no século $\mathrm{XIX}^{9}$. Na recente obra organizada por Philippe Contamine e Olivier Bouzy, Jeanne d'Arc - Histoire et Dictionaire, há um capítulo informativo acerca dos estudos joânicos que foram divididos temática e cronologicamente ${ }^{10}$. Quando garimpamos análises sobre a primeira

\footnotetext{
${ }^{7}$ WHITE, Hyden. Meta-história. A imaginação histórica do século XIX. São Paulo: Edusp: 1995.

${ }^{8}$ Como os livros de Régine Pernoud: Vie et mort de Jeanne D'Arc: les témoignes du procès de réhabilitation 1450-1456. Paris: Hachette, 1953. La liberation d'Orléans: 8 mai 1429. Paris: Gallimard, 1969. Jeanne D'Arc. Paris: Fayard, 1986. Réhabilitation de Jeanne D'Arc, reconquête de la France. Monaco: Rocher, 1995. Cf. também a biografia escrita por Collete Beaune: Joana d'Arc. op. cit.

${ }^{9}$ Uma das obras mais importantes que revelam tal esforço é o livro de Gerd Krumeich, Jeanne d'Arc à travers l'histoire. Albin Michel, 1993.

${ }^{10}$ BOUZY, Olivier, CONTAMINE, Philippe \& HÉLARY, Xavier. Op. cit. p. 1112-1122.
} 
metade do século XIX, encontramos apenas quatro trabalhos ${ }^{11}$ enquanto que ao contabilizarmos os estudos que se dedicam à contemporaneidade de Joana - do seu nascimento à fogueira - encontramos 72 análises!

$\mathrm{O}$ momento que se segue às publicações dos processos de condenação e anulação $^{12}$ - década de 50 do século XIX - muitas vezes é visto como o ponto de partida para análises dessa nova atribuição conferida à Joana ${ }^{13}$. Da mesma forma, muito se fala sobre sua retomada pelos católicos a partir da década de $1850^{14}$ ou no contexto da Terceira República e/ou após a perda da Alsácia-Lorena. ${ }^{15}$ Em outros casos, privilegiase o momento de sua canonização e os conflitos que lhe deram origem de acordo com a agenda política anterior à Primeira Grande Guerra. ${ }^{16}$

A nosso ver, apesar de todas essas discussões se constituírem em pontos importantíssimos para a análise da crescente popularização da Donzela no XIX e no

\footnotetext{
${ }^{11}$ CONTAMINE, Philippe. "Jules Quicherat historien de Jeanne d'Arc". In: De Jeanne d'Ac aux guerres d'Italie. Figures, images et problèmes du XVe siécle. Orléans: Paradigme, 1994. P. 179-191; GURY, Jacques. "L'historien et les mythes de Jeanne d'Arc des Lumières au Romantisme". In: Jeanne d'Arc. Une époque, un rayonnement. Colloque d'histoire médiévale. Orléans, 1979; MILLET, Claude. La Jeanne d'Arc de Michelet: histoire d'un seuil. In: Images de Jeanne d'Arc. Actes du colloque de Rouen. Presses Universitaires de France: Paris, 2000. P. 197-206. VIALLANEIX, Paul. "La Jeanne d'Arc de Jules Michelet, légende romantique". In: Travaux de linguistique et de litérature, t. XVII, no 2 , Études littéraires. Strasbourg. 1979, p. 05-114.

Duas recentes pesquisas de doutorado abordam temáticas que não se detêm à primeira metade do século XIX, apesar de passarem por ela. A tese de Julie Déramond "Jeanne d'Arc en accords parfaits. Musiques johanniques en France entre 1800 et 1939 " defendida em 2009 na Université de Toulouse-le-Mirail, e o trabalho de Yann Rigolet em andamento na Université d'Orléans que aborda a comparação entre Joana d'Arc e Marianne entre os séculos XIX e XX.

12 A historiografia joânica mais recente denomina "Processo de Anulação" aquele que invalida a condenação de Joana em 1431. Cabe ressaltar, conforme notou Colette Beaune, que é um erro histórico denominá-lo "Processo de Reabilitação", pois seu objetivo não era reabilitar Joana, mas apenas anular a condenação. No entanto esse processo foi publicado no século XIX por Jules Quicherat com o nome de Processo de Reabilitação, como veremos no $4^{\circ}$ capítulo. BEAUNE, C. o. cit.

${ }^{13}$ Cf. CLUZEL, J. Jeanne d'Arc. La politique par d'autres moyens. Economica, 2006.

14 BOUDON, J-O. "La figure de Jeanne d'Arc chez les catholiques français du XIXe siècle". In: MAURICE, J. \& COUTY, D. Images de Jeanne d'Arc. Actes du colloque de Rouen. Presses Universitaires de France: Paris, 2000.

${ }^{15}$ CLUZEL, J. "Wallon, Jeanne d'Arc et la République". [on line] Séance en hommage à AlexandreHenri Wallon. Académie des sciences morales et politiques. Paris, 2004. Disponível em: http://www.asmp.fr/travaux/exceptionnelles/cluzel_wallon.pdf. Consultado em 25/03/2008.

${ }^{16}$ SNIPES-HOYT ,Carolyn. "Jeanne d'Arc Visits Paris in 1912: Dramatis personae and Personification". In: The French Review, Vol. 73, No. 6. (May, 2000), pp. 1141-1154.
} 
$\mathrm{XX}$, há que se preencher uma lacuna nesse processo. Essa lacuna corresponde ao momento inicial desse fenômeno que ocorre no contexto pós-revolucionário no qual a historiografia via-se envolvida em debates que visavam responder a preocupações de seu próprio tempo. Nas atas do colóquio Imagens de Joana d'Arc, realizado em maio de 1999 em Rouen, observamos que, apesar da maioria dos expositores terem se preocupado com imagens de Joana em períodos variados, não há nenhum texto que priorize o período inicial da renovação dessa imagem no século $\mathrm{XIX}^{17}$.

Longe de representar uma busca orientada pelo mito das origens, essa pesquisa pretende privilegiar os momentos iniciais dessa mudança, negligenciado até então pela historiografia, como forma de compreender como os elementos se arranjaram nessas narrativas e como essa combinação foi de tal forma convincente a ponto de ultrapassar os debates historiográficos e acadêmicos, transformando Joana em um ícone que não se conteve em fronteiras partidárias, religiosas (como prova a ideia de Joana como prefiguração de Lutero e Calvino por parte dos protestantes) ou sociais. Sua história interessou ao cinema, do cult ao hollywoodiano, à literatura, e mereceu centenas de biografias escritas por autores variados, de Marc Twain a Érico Veríssimo. Uma imagem construída, popularizada e, por fim, universalizada. A nosso ver esse processo teve um momento inicial fundamental no qual a historiografia associou à história de Joana d'Arc algo que poderia responder a seus anseios e preocupações.

A seleção dos autores que serão aqui analisados partiu dessas considerações. A pesquisa revelou que o limite cronológico estabelecido - primeira metade do século XIX - deve ser flexibilizado. O pressuposto de uma ruptura em relação à forma como Joana

\footnotetext{
${ }^{17}$ MAURICE, J. \& COUTY, D. Images de Jeanne d'Arc. Actes du colloque de Rouen. Presses Universitaires de France: Paris, 2000.
} 
d'Arc era vista até então - que correspondesse à virada do século, ou mesmo ao advento da Revolução Francesa - não se sustentou no trabalho com as fontes. Dessa forma incluiremos em nosso corpus documental duas obras escritas no final do século XVIII por Clément de L'Averdy que são de suma importância para compreender as temáticas que pretendemos abordar nesse trabalho.

Nossa seleção buscou ultrapassar denominações como "historiografia romântica" e "historiografia liberal" e não pretendeu separar os autores de acordo com sua filiação político/ideológica, o que os limitaria como "monarquistas" ou "republicanos". Não tentamos encaixar os autores escolhidos dentro de uma perspectiva que pudesse limitar a compreensão a seu respeito, mas antes considerar os principais temas que interessavam à historiografia da época tentando compreender em que medida elas influenciam a visão desses autores sobre Joana d'Arc.

A edição dos Processos de Condenação e de Reabilitação de Joana d'Arc a cargo de Jules Quicherat sob a tutela da então jovem Sociedade de História da França, publicada nos anos 40 do século XIX, fecha o período da análise que aqui se propõe, uma vez que posteriormente terá início uma apropriação progressiva dos católicos conformando um período distinto de debates sobre Joana d'Arc.

Será seguido um caminho original uma vez que as análises anteriores, como vimos, contemplaram esse tema em ambientes nos quais a polarização política se fez em termos mais contundentes, como no contexto do conflito político (e por Joana d'Arc) entre republicanos e católicos na segunda metade do século XIX. Além disso, autores como Berriat Saint-Prix, Lebrun des Charmettes e Sismonde de Sismondi são negligenciados como biógrafos de Joana d'Arc, que é sempre vista, na maior parte dos casos, como a heroína micheletiana por excelência. Longe de negar a importância 
angular da interpretação de Michelet, pretende-se alargar a discussão colocando esses autores em certa tradição historiográfica, para observar como se deu a evolução das problemáticas em torno da Donzela.

A obra de Michelet entra em nossa análise por trazer pistas importantes a respeito desse processo que denominamos "a ressignificação de Joana d'Arc no século XIX”. Considerado um marco para a historiografia joânica, ela é abordada muitas vezes tendo em vista sua originalidade, conforme argumentam vários autores. Para Winock, Michelet foi o grande responsável por transformar a imagem de Joana d'Arc fazendo dela o paradigma do heroísmo e do bom senso popular e, sobretudo, a iniciadora do sentimento nacional ${ }^{18}$. Seguindo a mesma linha interpretativa, Krumeich afirma que "Nenhum outro escritor e historiador teve um papel tão determinante na popularização e no desenvolvimento da imagem de Joana no século XIX - e até nossos dias - como Michelet."19

Consideramos que se deve ter cautela ao interpretar a obra de Michelet a respeito de Joana d'Arc, pois em geral ela não é analisada em sua especificidade, mas tendo como perspectiva os demais trabalhos desse autor. Assim se eclipsa a importância de outras obras da historiografia joânica, reificando as ideias de quebra, ruptura e mudança que não permitem grande avanço no problema da ressignificação de Joana d'Arc no século XIX. Não se trata de desconsiderar a importância da obra de Michelet, mas de dar a ela o seu devido lugar nesse processo mais amplo no qual ela é apenas mais um testemunho. Mesmo Krumeich diz que a estrutura da Jeanne d'Arc de Michelet é a mesma de Barante e Sismondi, lembrando que sua originalidade consiste em servir-se

\footnotetext{
${ }^{18}$ WINOCK, M. "Jeanne d'Arc”. In: NORA, Pierre. Les lieux de mémoire. Paris: Galimard. 1984. p. 4427-4544. v. 3.

${ }^{19}$ KRUMEICH, G. op. cit. p. 71.
} 
da noção de povo que, apesar de criada antes dele, teve seu sentido alargado em suas obras.

O próprio Michelet tentou se destacar em relação aos outros historiadores que escreveram sobre Joana d'Arc. Segundo ele o que separava sua obra da tradição retórico-literária foi o fato de ele ter sido o primeiro a escrever a história da Donzela em contato permanente com as fontes e os arquivos ${ }^{20}$. Mas sabe-se que a maior parte dos autores antes de Michelet fizeram isso, e de forma sistemática, desde l'Averdy. Gustave Rudler $^{21}$ chega a dizer que Michelet parafraseou Lebrun des Charmettes. Vemos, portanto, que é necessário questionar a obra de Michelet como a encarnação de uma nova Joana d'Arc que teria sido a causa da popularização extrema pela qual passou sua figura posteriormente. Na verdade ele não deu início a esse processo, em nossa opinião sua obra é fruto de um processo iniciado no início do século XIX.

Cabe esclarecer que não farão parte de nosso corpus documental as obras literárias produzidas no período em questão por termos optado pela visão historiográfica em relação à Donzela. Por essa mesma razão, não serão alvo de nossa análise as os quadros, vitrais, estátuas e demais monumentos erguidos em homenagem à Joana d'Arc. O que nos ocupa é investigar a relação entre a construção do campo histórico como saber científico na França do século XIX atrelada à ressignificação do passado em sentido amplo, à Idade Média em particular e à Joana d'Arc em sentido específico. Apesar disso, ao longo do trabalho iremos nos valer de algumas obras artísticas que apresentam Joana d'Arc que, como sabemos, conta com riquíssimo arsenal

\footnotetext{
${ }^{20}$ MICHELET, J. Jeanne d'Arc. Avec une introd. et un répertoire explicatif des notes de Michelet par Émile Bourgeois. Paris: Librairie Hachette. 1909.

${ }^{21}$ RUDLER, G. Michelet: historien de Jeanne d'Arc. Paris : Puf, 1925.
} 
iconográfico. São reproduções de estátuas, quadros e fotos que serão incluídos no trabalho na medida em que forem pertinentes à discussão em questão.

Em seguida, apresentaremos os autores e obras que serão analisados nessa tese.

\begin{tabular}{|c|c|c|}
\hline Autores & Obras analisadas & Justificativa da escolha \\
\hline $\begin{array}{l}\text { Clément de } \\
\text { L'Averdy }\end{array}$ & $\begin{array}{l}\text { Mémorial lu au comité des } \\
\text { manuscrits concernant la } \\
\text { recherche à faire des minutes } \\
\text { originales des différentes affaires } \\
\text { qui ont eu lieu par rapport à } \\
\text { Jeanne d'Arc, appelée } \\
\text { communément lar Pucelle } \\
\text { d'Orléans. Paris, Imprimerie } \\
\text { Royale, 1787. } \\
\text { Notices et extraits des manuscrits } \\
\text { de la Bibliothèque du roi, lus au } \\
\text { comité établi par sa Majesté dans } \\
\text { l'Académie royale des } \\
\text { Inscriptions et Belles Lettres, } \\
\text { Paris, Imprimerie Royale, } 1790 .\end{array}$ & $\begin{array}{l}\text { As publicações de L'Averdy } \\
\text { foram uma tentativa } \\
\text { criteriosa de recolher, editar } \\
\text { e esclarecer o Processo de } \\
\text { Condenação além de várias } \\
\text { outras fontes em relação à } \\
\text { Joana d'Arc. A partir desses } \\
\text { trabalhos poderemos } \\
\text { verificar em que medida a } \\
\text { ideia de originalidade do } \\
\text { século XIX em relação às } \\
\text { fontes joânicas é ou não } \\
\text { válida. }\end{array}$ \\
\hline Berriat Saint-Prix & $\begin{array}{l}\text { Jeanne d'Arc ou coup d'oeil sur } \\
\text { les révolutions en France au } \\
\text { temps de Charles VII et surtout de } \\
\text { La Pucelle d'Orléans - } 1817 \text {. }\end{array}$ & $\begin{array}{l}\text { Essa obra muitas vezes } \\
\text { negligenciada pela posição } \\
\text { política do autor, que à época } \\
\text { da Restauração marca sua } \\
\text { posição monarquista e em } \\
\text { defesa da Igreja Católica, } \\
\text { nunca mereceu o espaço } \\
\text { merecido na construção de } \\
\text { uma tradição historiográfica } \\
\text { joânica do século XIX. }\end{array}$ \\
\hline $\begin{array}{l}\text { Lebrun des } \\
\text { Charmettes }\end{array}$ & $\begin{array}{l}\text { Histoire de Jeanne d'Arc, } \\
\text { surnommée la Pucelle d'Orléans, } \\
\text { tirée de ses propres déclarations, } \\
\text { de cent quarante-quatre } \\
\text { dépositions de témoins oculaires, } \\
\text { et des manuscrits de la } \\
\text { Bibliothèque du roi et de la la } \\
\text { Tour de Londres. } 1819.4 \\
\text { volumes. }\end{array}$ & $\begin{array}{l}\text { Da mesma forma que a obra } \\
\text { de Saint-Prix, o trabalho de } \\
\text { Charmettes sofreu } \\
\text { preconceito pelas suas } \\
\text { posições políticas, tanto pelo } \\
\text { fato de o autor ter tido } \\
\text { importantes postos políticos } \\
\text { durante a Restauração como } \\
\text { por suas obras posteriores } \\
\text { marcadas pas pelo } \\
\text { antiliberalismo, como as } \\
\text { Épitres politiques sur nos } \\
\text { extravagances de } 1831 .\end{array}$ \\
\hline
\end{tabular}




\begin{tabular}{|c|c|c|}
\hline $\begin{array}{l}\text { Sismonde de } \\
\text { Sismondi }\end{array}$ & $\begin{array}{l}\text { Começa a publicar em } 1821 \text { sua } \\
\text { Histoire des français e Joana } \\
\text { d'Arc aparece no } 13^{\circ} \text { volume de } \\
\text { sua obra, publicado em } 1831 \text {, no } \\
\text { qual ele lhe dedica } 100 \text { páginas. }\end{array}$ & $\begin{array}{l}\text { Será importante investigar } \\
\text { como esse suiço, considerado } \\
\text { por Michelet o iniciador das } \\
\text { pesquisas históricas na } \\
\text { França, pôde contribuir para } \\
\text { a renovação da imagem } \\
\text { Joana d'Arc. Além disso, } \\
\text { Sismondi caiu no } \\
\text { esquecimento, sendo } \\
\text { raramente citado, tanto em } \\
\text { relação à sua contribuição à } \\
\text { historiografia francesa, } \\
\text { quanto em relação à sua } \\
\text { interpretação de Joana d'Arc. }\end{array}$ \\
\hline Jules Michelet & $\begin{array}{l}\text { Em 1841, ele escreve o capítulo X } \\
\text { no tomo V da Histoire de France } \\
\text { de título "Charles VII - a Donzela } \\
\text { de Orléans". Esse capítulo será } \\
\text { publicado posteriormente, em } \\
\text { 1853, somente com o título } \\
\text { Jeanne d'Arc. }\end{array}$ & $\begin{array}{l}\text { Michelet é o mais conhecido } \\
\text { dos biógrafos de Joana } \\
\text { d'Arc, além de ser } \\
\text { considerado um dos maiores } \\
\text { historiadores franceses do } \\
\text { século XIX. Pretendemos } \\
\text { analisar em que medida sua } \\
\text { obra a respeito da Donzela é } \\
\text { parte de uma tradição da qual } \\
\text { ele foi tributário. Esse } \\
\text { pertencimento, no entanto, } \\
\text { não o impediu de reelaborar } \\
\text { certos elementos } \\
\text { fundamentais para o novo } \\
\text { significado atribuído à Joana } \\
\text { d'Arc no século XIX. }\end{array}$ \\
\hline
\end{tabular}




\begin{tabular}{|c|c|c|}
\hline Jules Quicherat & $\begin{array}{l}\text { Entre } \mathbf{1 8 4 1} \mathbf{1 8 4 9} \text { Jules } \\
\text { Quicherat publica, em nome da } \\
\text { Societé d'Histoire de France, o } \\
\text { Procès de condamnation et de } \\
\text { réhabilitation de Jeanne d'Arc, } \\
\text { dite la Pucelle, publiés pour la } \\
\text { première fois d'après les } \\
\text { manuscrits de la Bibliothèque } \\
\text { nationale, suivis de tous les } \\
\text { documents historiques qu'on a pu } \\
\text { réunir, et accompagnés de notes } \\
\text { et d'éclaircissements em } 5 \text { tomos. } \\
\text { Em } \mathbf{1 8 5 0} \text { ele publica Aperçus } \\
\text { nouveaux sur l'histoire de Jeanne } \\
\text { d'Arc no qual ele expõe suas } \\
\text { impressões em relação à Donzela. }\end{array}$ & $\begin{array}{l}\text { Pela primeira vez houve uma } \\
\text { edição integral dos processos } \\
\text { de Joana d'Arc. Por mais de } \\
\text { um século essa edição se } \\
\text { manteve como base para as } \\
\text { pesquisas sobre Joana. } \\
\text { Além da edição crítica e } \\
\text { comentada dos processos, } \\
\text { Quicherat também publicou } \\
\text { crônicas, cartas, documentos } \\
\text { diversos obre Joana, vários } \\
\text { deles inéditos. } \\
\text { - Quicherat teve seu projeto } \\
\text { de edição financiado pela } \\
\text { Sociedade de História da } \\
\text { França que, antes, já havia } \\
\text { recusado esse mesmo projeto } \\
\text { feito por Guido Görres, já } \\
\text { que ele era alemão. }\end{array}$ \\
\hline
\end{tabular}

O presente trabalho foi organizado em quatro capítulos. O primeiro capítulo permitirá introduzir o elemento norteador do trabalho: a ideia de ressignificação. Pretendemos relacioná-lo com as discussões que envolveram a Revolução Francesa em função de sua relação com o passado e com Joana d'Arc. Sem dúvida, Joana foi ressignificada dentro de um movimento geral de interesse pela Idade Média pensada como infância nacional francesa. Mas percebemos que a imagem da Donzela de Orléans moldada no século XIX é parte de um fenômeno mais amplo que envolveu uma necessidade de se posicionar diante do problema destruição versus conservação.

No segundo capítulo vamos apresentar os gêneros que mais influenciaram os escritores que se dedicaram à Joana d'Arc na primeira metade do século XIX: a 
biografia e a História Nacional. Pretendemos ver em que medida a presença de elementos desses dois tipos de textos é sintoma de uma relação estabelecida entre o particular e o geral, o individual e o coletivo. Um dos elementos de destaque nessa tensão é a ressignificação da ideia do entusiasmo de Joana d'Arc, ora visto como elemento individual que se expande à coletividade, ora como característica do povo encarnado em Joana d'Arc. Pretendemos demonstrar que esse é o ponto fundamental na mudança em relação às histórias de Joana d'Arc: foi a partir da ressignificação do entusiasmo que ela pôde ser vista como propositora da liberdade civil.

O terceiro capítulo tem como objetivo analisar como as ideias de "povo" e "nação" foram importantes no processo de ressignificação de Joana d'Arc. Tais conceitos teriam recebido a influência do chamado "movimento romântico" termo que pretendemos testar em função de sua aplicabilidade em relação à historiografia joânica. Iremos discutir também a importância da projeção do culto à Joana para toda a França como tentativa de estabelecer uma identidade nacional almejada, porém muito distante naquele momento.

No quarto capítulo iremos abordar a forma como o passado foi ressignificado como Ciência a partir da noção de História Científica. Em relação à Joana d'Arc os seus processos de condenação e anulação da condenação foram sendo analisados, mediante um método dito histórico, de forma sistemática a partir do século XIX. Pretendemos, no entanto, demonstrar a importância do século XVIII para a crítica e análise dessas fontes, pois consideramos que a historiografia do XIX foi antes uma continuadora desse processo a partir de um novo significado que a História assume na sociedade oitocentista, do que a responsável por iniciar uma historiografia de Joana d'Arc atrelada às fontes. Por fim discutiremos a noção de uma verdade histórica atribuída à trajetória 
de Joana d'Arc que foi construída de acordo com um discurso conveniente ao contexto político de então, validado pela Ciência e fomentado pelo Estado.

\section{Seleção de imagens - Joana d'Arc: uma heroína, várias faces}

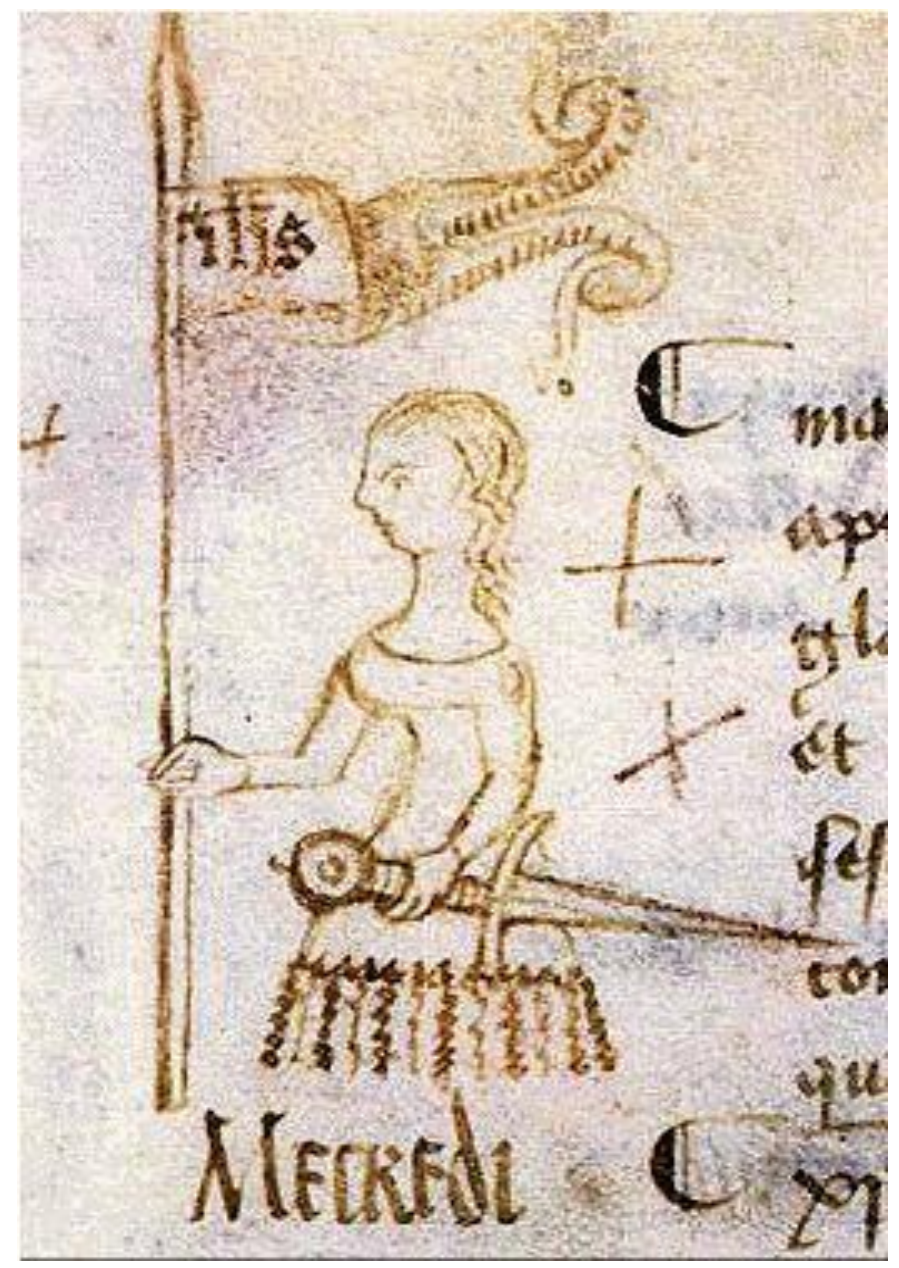

Figura 1 - A mais antiga representação iconográfica de Joana d'Arc que se tem notícia. Clément de Fauquembergue, desenho feito à margem de um registro do Parlamento de Paris, 10 de maio1429.

http://clioweb.canalblog.com/tag/colettebeaune. Acesso em abril de 2012. 


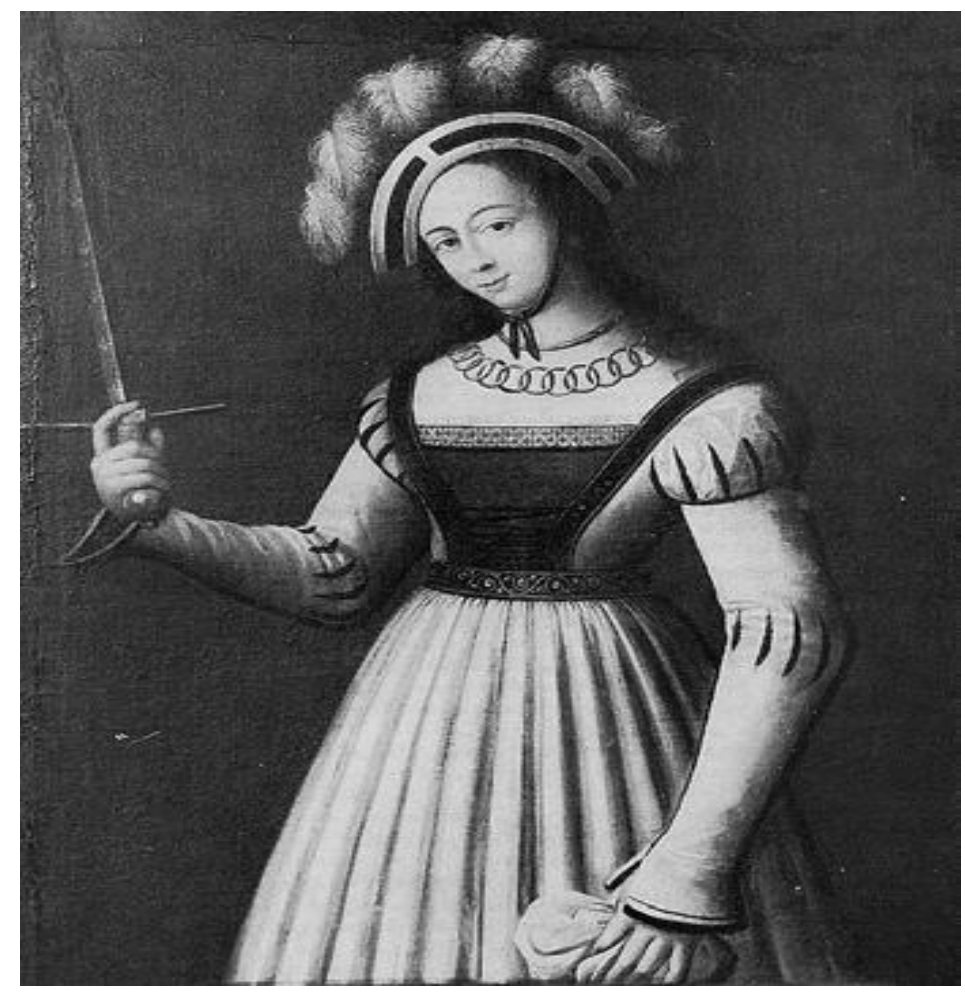

Figura 2 - Retrato de Joana conhecido como "dos Échevins." Autor desconhecido, 1581.

Fonte: MICHAUD-FRÉJAVILLE, F. Jeanne d'Arc aux panaches romantiques" , dans Bulletin de la Société archéologique et historique de l'Orléanais, n.s., 16/131, 2002, p. 4.

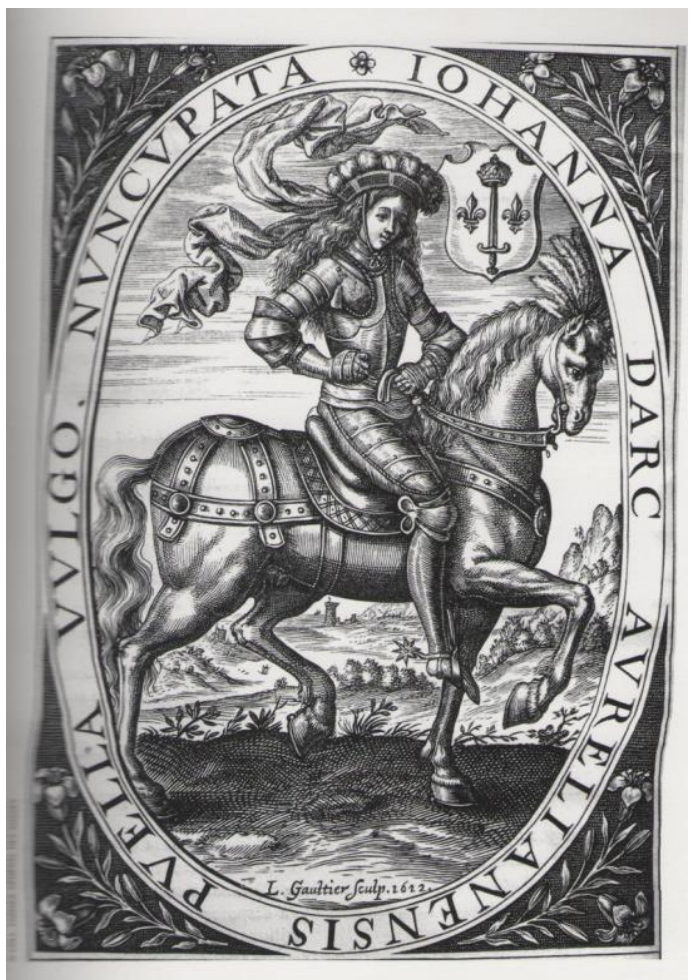

Figura 3 - Gravura de L. Gautier na obra de Jean Hordal, Heroinae nobilissimae Joannae D'Arc Lotharingae vulgo Aurelianensis puellae historia...Pont-à-Mousson, Melchior Bernard, 1612.

Fonte: MARTIN, Philippe (org). Jeanne d'Arc: les métamorphoses d'une hérö̈ne. Place Stanislas, 2009. P. 29. 

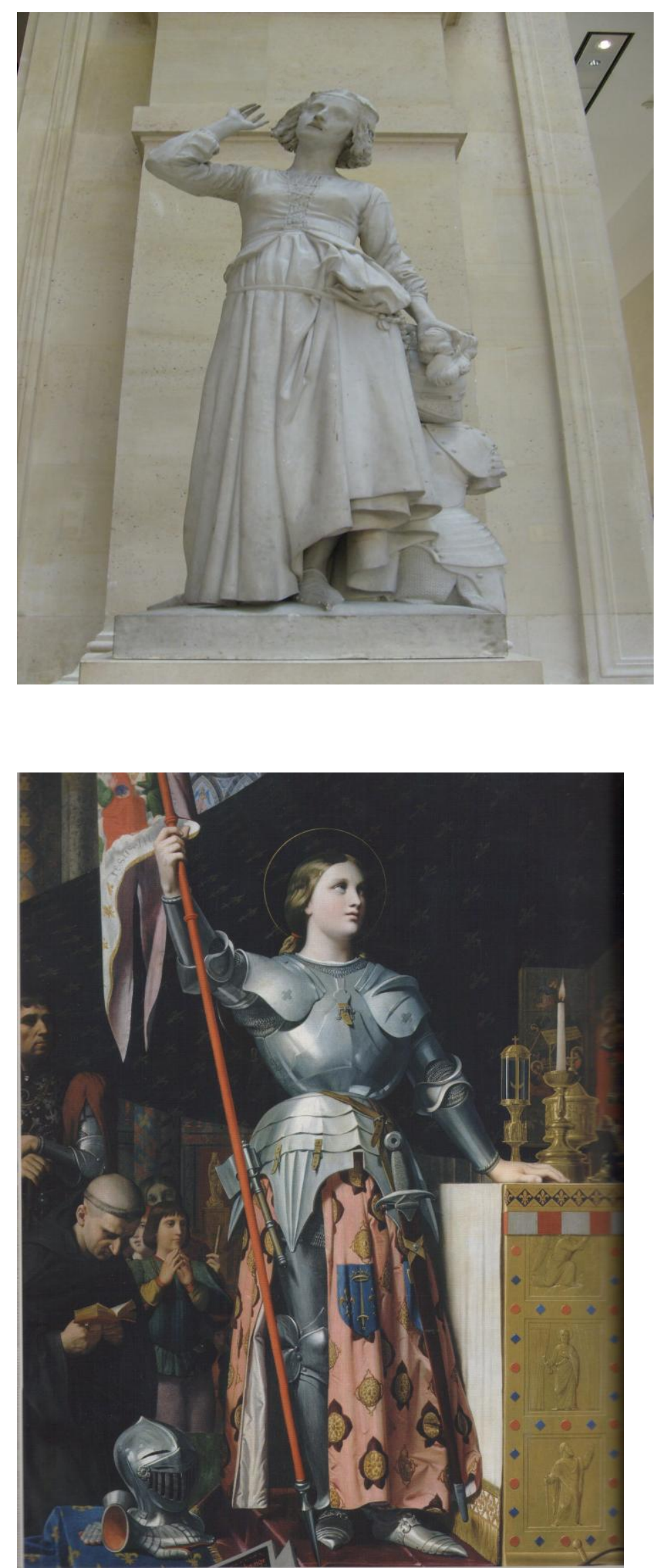

Figura 4: Joana d'Arc ouvindo suas vozes. François Rudé, 1852. Museu do Louvre.

Fonte: Foto, arquivo pessoal, 2009.

Figura 5: Joana d'Arc na coroação de Charles VII, na catedral de Reims. JeanDominique Ingrés. 1854. Museu do Louvre.

Fonte: MARTIN, Philippe (org) op. cit. p. 46. 

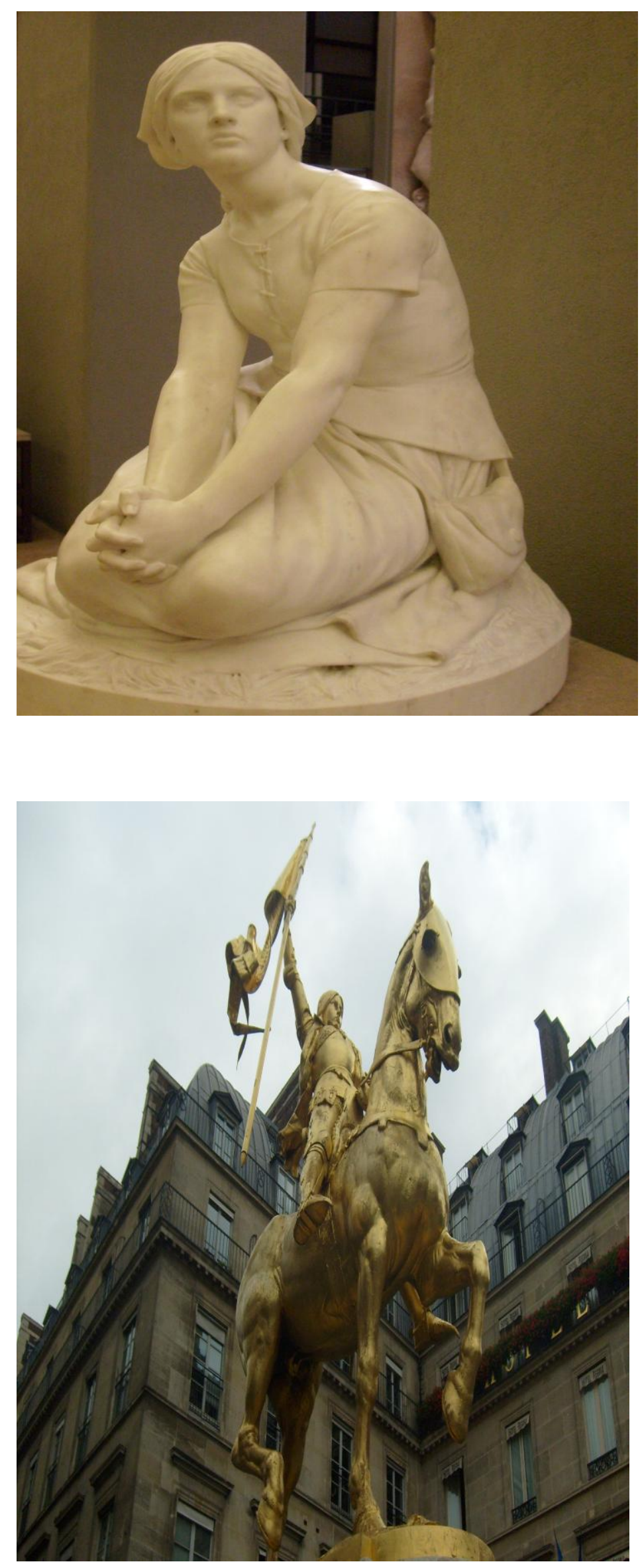

Figura 6: Joana d'Arc en Domrémy. Henri Chapu 1872. Museu d'Orsay.

Foto, arquivo pessoal, 2009.
Figura 7: Jeanne d'Arc. Émannuel Frémiet, 1899. Paris, Place des Pyramides.

Foto. Arquivo pessoal, 2009. 


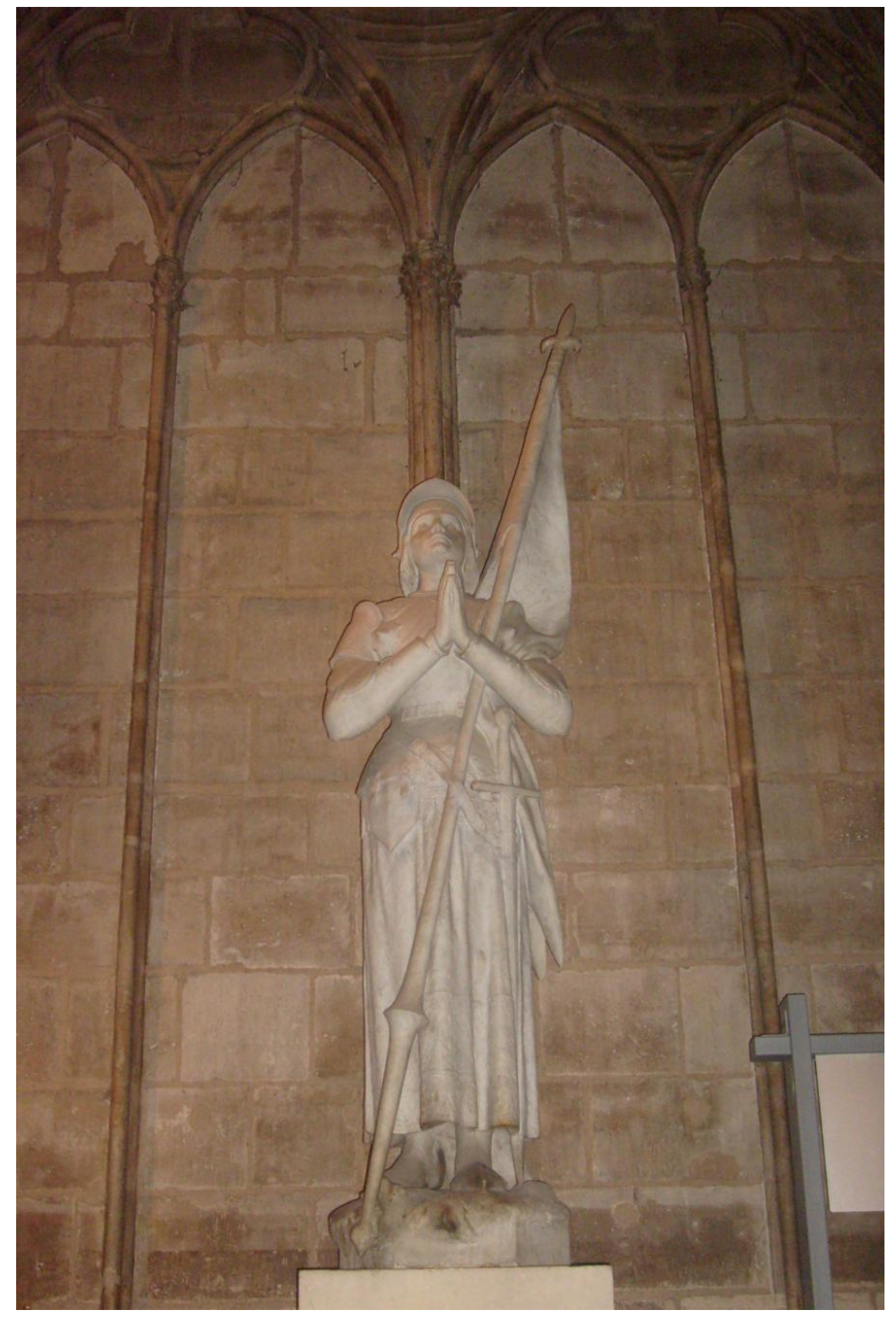

Figura 8: Estátua de Joana d'Arc na Notre Dame de Paris. Charles Desvergnes, 1920.

Foto. Arquivo pessoal, 2009. 


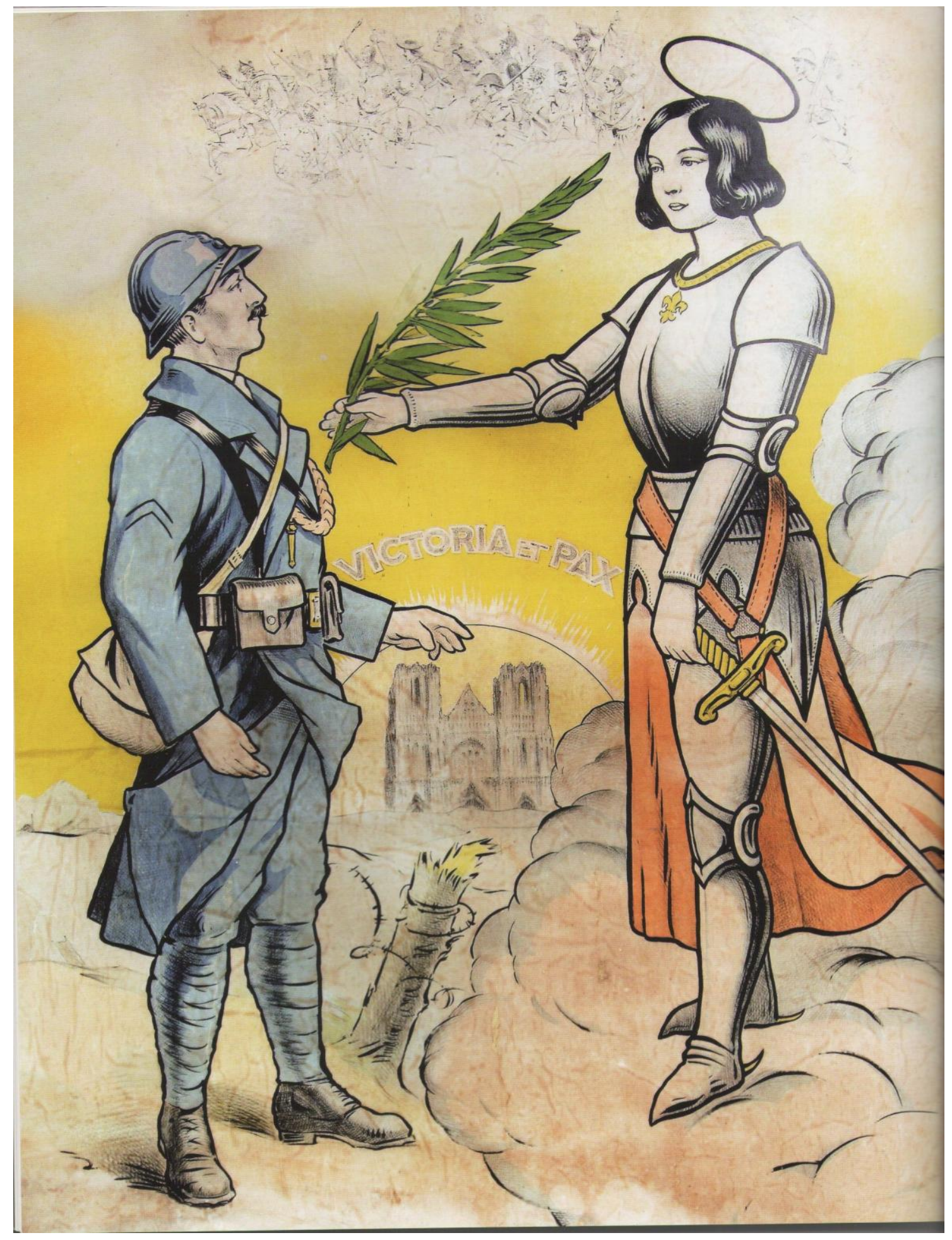

Figura 9: Joana saudando um poilu vitorioso. Cartaz, 1918.

Fonte: MARTIN, Philippe (org). op. cit. p. 166. 

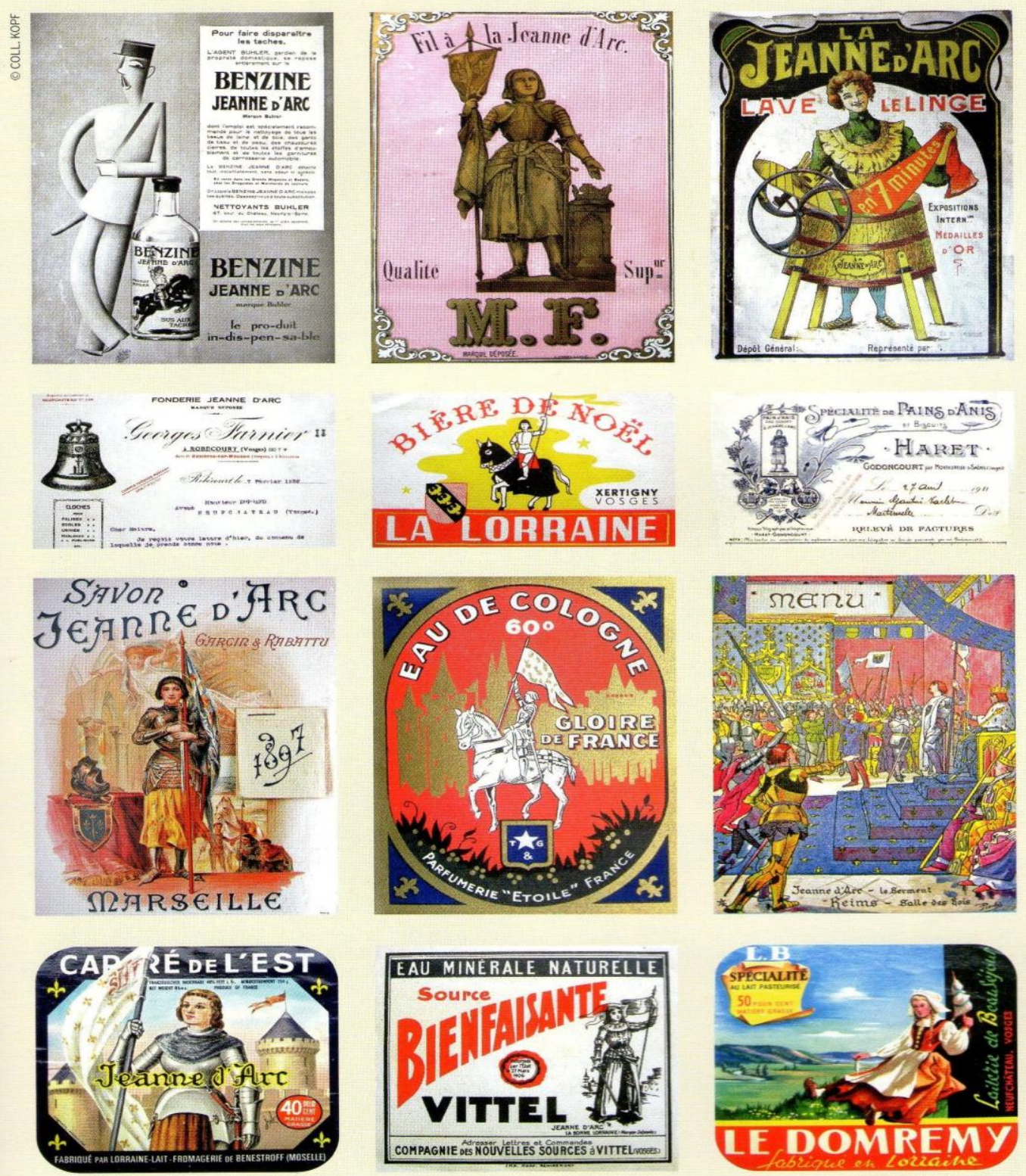

Figura 10: Joana d'Arc e a publicidade - um fenômeno que passa a ser cada vez mais comum a partir do final do século XIX.

Fonte: MARTIN, Philippe (org). op. cit. 2009. p. 153.

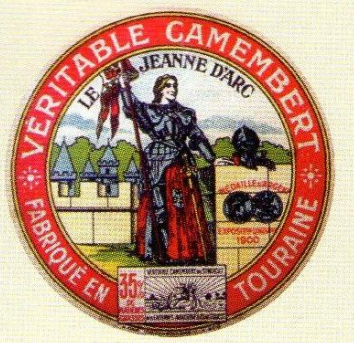




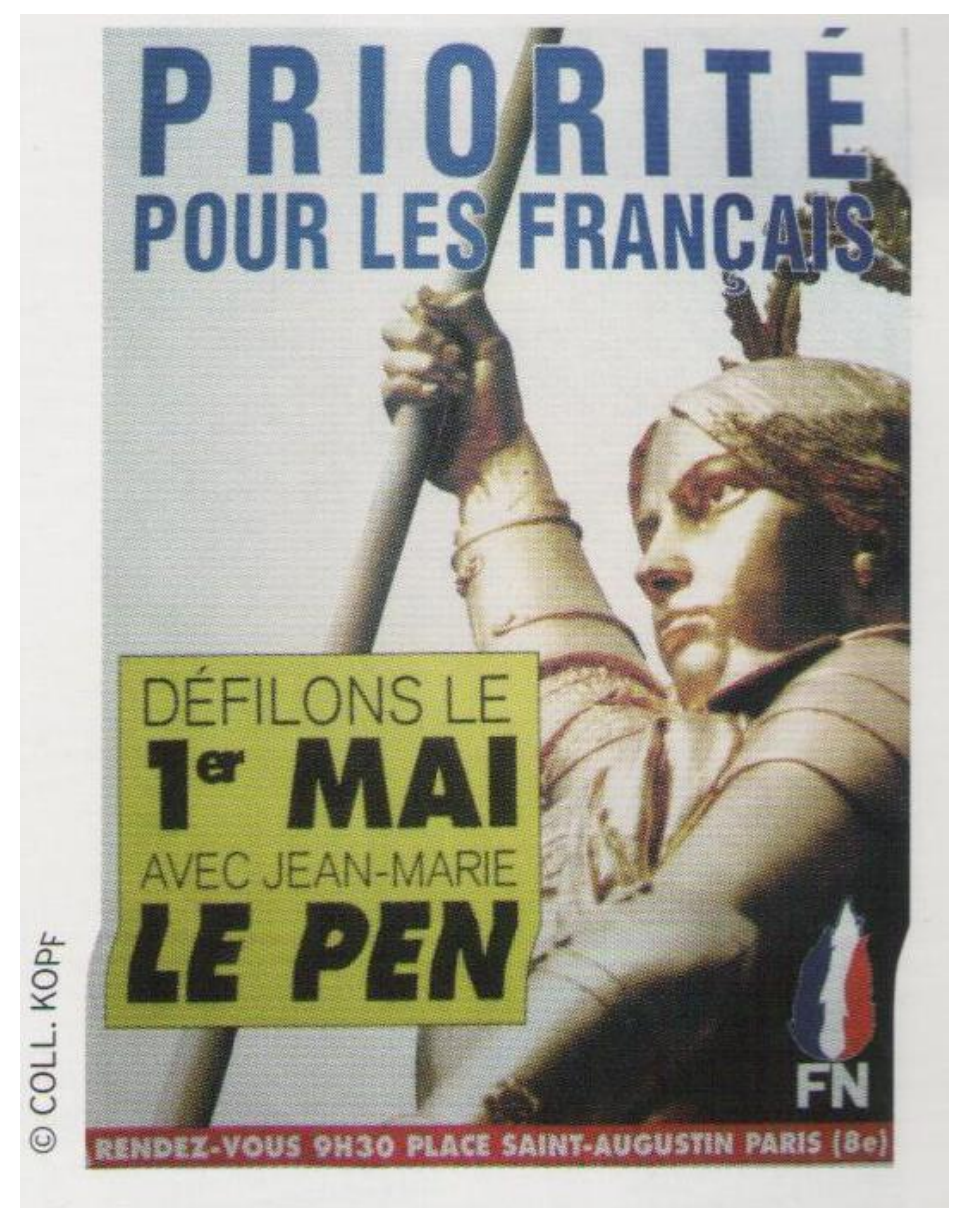

Figura 11: Cartaz da Frente Nacional. Convite para a comemoração do $1^{\circ}$ de maio com Jean Marie Le Pen: a extrema direita francesa escolhe festejar o dia do trabalho com Joana d'Arc para combater o significado internacional da data.

Fonte: MARTIN, Philippe (org). op. cit. p. 175.

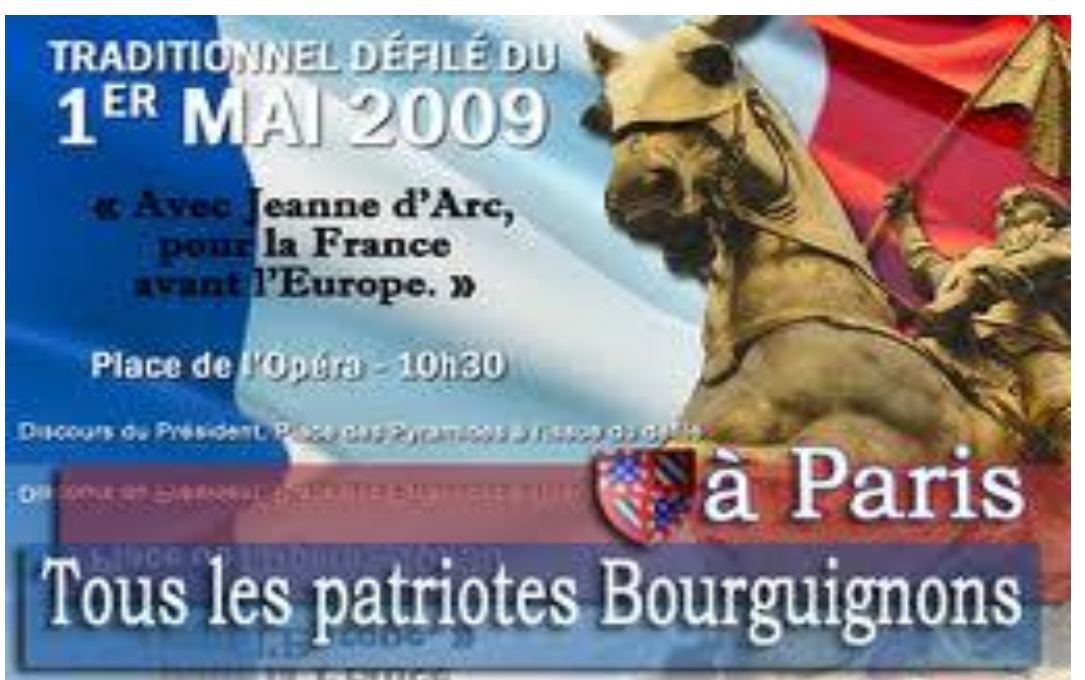

Figura 12: Cartaz da Frente Nacional. Ironia do destino: o cartaz convida os borguinhões que na Guerra dos Cem Anos venderam Joana d'Arc aos ingleses - a se unirem à causa da Donzela pela França!

\section{Fonte:}

http://fnbourgogne.hautetfort.com/tag/ front\%20national. Acesso: 20/04/12 

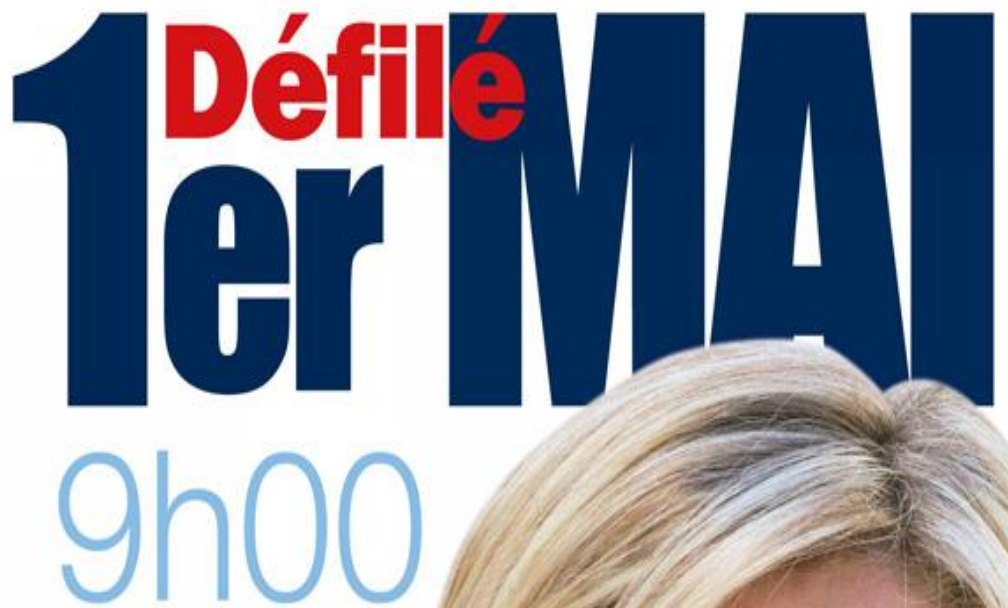

Rendez-vous angle rue de Rivoli Place du Palais Royal

Discours de MARINE

\section{LE PEN}

à l'issue du défilé

Place de l'opjéra

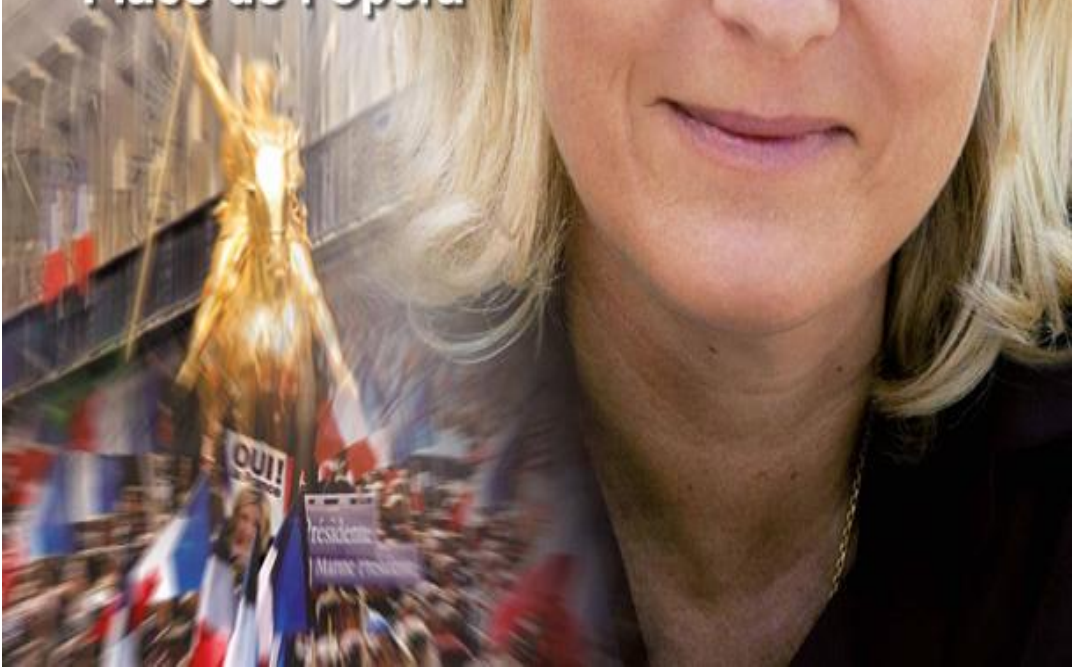

Figura 13: Cartaz da Frente Nacional. Convite para comemorar o $1^{\circ}$ de maio de 2012 com a recém-derrotada no pleito de 22 de abril. Com a frase "Sim! A França", Marine fez de sua campanha eleitoral uma batalha contra a islamização do seu país. Em muitos cartazes ela aparece ao lado de Joana d'Arc. Ao longo da campanha essa associação foi satirizada: Marine seria uma donzela que também ouvia vozes dizendo que deveria colocar os estrangeiros fora da França!

Fonte:

http://www.frontnational.com/2 


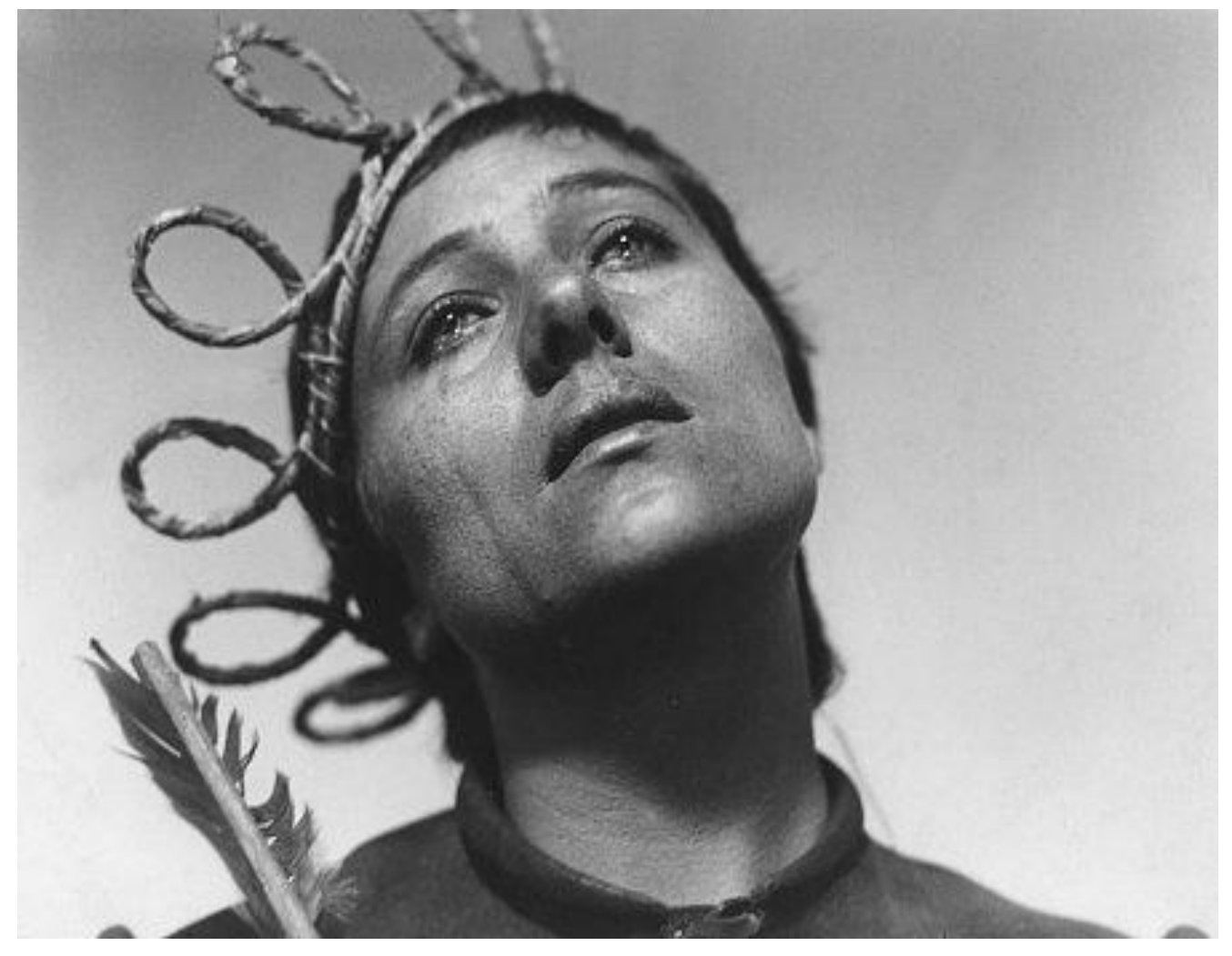

Figura 14: Renée Falconetti, a mais marcante Joana d'Arc do cinema. $L a$ Passion de Jeanne d'Arc, de Carl Theodor Dreyer de 1927.

Fonte:

http://www.listal.com/v iewimage/864399 Acesso: 02/12

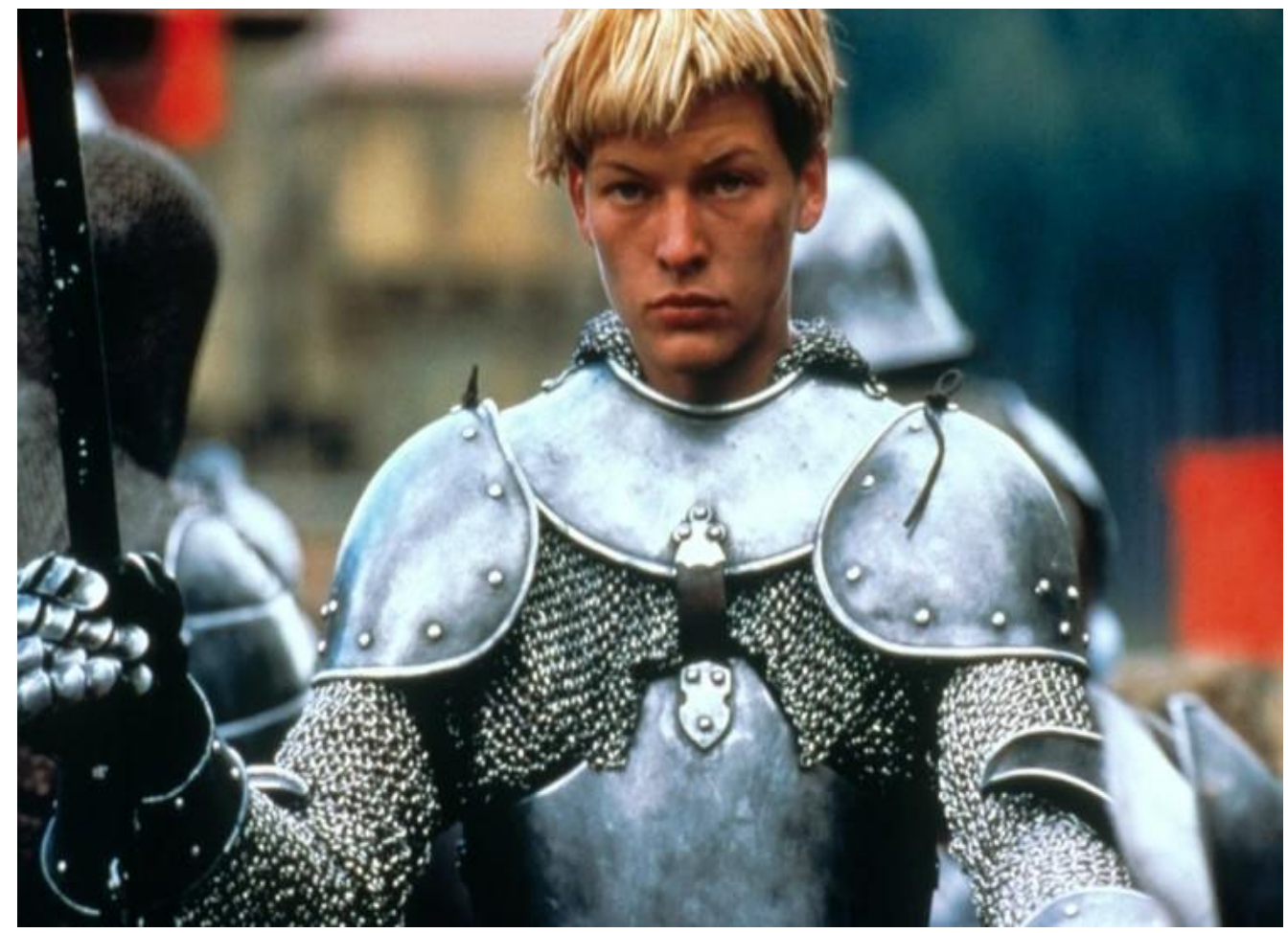

Figura 15: Milla Jovovich, a Joana d'Arc de Luc Besson. The Messenger: The Story of Joan of Arc. 1999.

Fonte: http://sul21.com.br/jornal/2011/09/ccmq-comemora-21-anos-com-atividades-gratuitas/ Acesso: 02/12 


\section{CAPÍTULO I - História, Revolução e Ressignificação}

"A História é filha da Revolução."

Febvre, 1942, p. 74.

"A Revolução cria os arquivos."

Garcia, 2005, p. 18

“A Revolução Francesa foi um evento decisivo para a reputação de Joana d'Arc." Lightbody, 1961, p. 157.

\section{1 - Joana d'Arc e a Revolução francesa}

Tradicionalmente as pesquisas afirmam que Joana d'Arc foi esquecida entre os séculos XVI, XVII e XVIII para ser retomada após a Revolução Francesa, sendo transformada após esse episódio em heroína nacional. Seguindo essa tradição historiográfica Winock, em relação à memória de Joana d'Arc, classifica os séculos XVI, XVII e XVIII como "séculos de inadequação ou esquecimento" e os séculos XIX e XX como "séculos de rememoração ativa",22. Essa ideia, porém tem sido questionada. ${ }^{23}$ Olivier Bouzy traz números que mostram um grande interesse daqueles séculos por Joana, contabilizando um total de 472 obras entre manuscritos dos processos, edições e reedições de crônicas a respeito da Donzela. Em comparação com os dias atuais, Bouzy detecta que, no século XVII, o número de publicações sobra Joana indica que aquele período se interessava dez vezes mais por ela do que o nosso ${ }^{24}$. Para esse autor, a insistência sobre o "esquecimento de Joana" viria de certa miopia dos

\footnotetext{
${ }^{22}$ WINOCK, M. "Jeanne d'Arc”. In: P. NORA, Pierre. Les lieux de mémoire. Paris: Galimard. 1984. p. 4427-4544. V. 3.

${ }^{23}$ BOUZY, Olivier. "Manuscrits inutiles et auteurs inconnus: la transmission du souvenir de Jeanne d'Arc du XVe au XVIIIe siècle", Bulletin des Amis du Centre Jeanne d'Arc, n 26, 2002, p. 23-52 ; MICHAUDFRÉJAVILLE, Françoise. "Personne, personnage : Jeanne d'Arc en France au XVIIe siècle." In: Jeanne d'Arc en garde à vue, sous la direction de Dominique Goy-Blanquet, Bruxelles, 1999, p. 55-77.

${ }^{24}$ Comparação entre o número total de publicação de livros na França entre 1629 e 1630 (1263) com o número de obras escritas sobre Joana d'Arc naquele período, duas. Comparação entre o número total de publicação de livros na França nos primeiros seis meses de 2005 (29670) e o número de obras escritas sobre Joana d'Arc, duas sobre ela propriamente dita e duas sobre sua época.
} 
autores que a partir do século XVIII, desejando uma interpretação diferente em relação à história da Donzela não se identificavam com a imagem de Joana veiculada pelos séculos anteriores. Ele conclui: “É então falso dizer que Joana d'Arc foi esquecida nos séculos XVI e XVII: é a imagem que esses dois séculos veicularam que foi abandonada pelos autores do século XVIII." ${ }^{, 25}$

Também Jeroom Vercruysse dedicou-se a demonstrar o grande interesse do século das Luzes por Joana d'Arc, ressaltando que não foi apenas Voltaire que se lembrou da Donzela em seu irônico poema La Pucelle d'Orléans, de 1762 . O autor estima que mais de cem obras relacionadas a Joana foram produzidas apenas na França, o que demonstra que aquele século se ocupou muito de sua história ${ }^{26}$.

Mas se Joana não foi esquecida pelos séculos anteriores, não há como negar o grande aumento do número de obras dedicadas a ela após a Revolução Francesa. Na famosa obra de Pierre Lanery d'Arc, Le livre d'or de Jeanne d'Arc, de 1894, o autor inventaria em torno de 2700 obras a respeito de Joana d'Arc no século XIX. Em comparação a outros personagens da Idade Média, ela ocupa um lugar de grande destaque nos séculos XIX e XX, como vemos no gráfico a seguir:

\footnotetext{
${ }^{25}$ BOUZY, op. cit., p. 37. Tradução nossa.

${ }^{26}$ VERCRUYSSE, Jeroom. Jeanne d'Arc au Siècle des Lumières. In: Studies on Voltaire and the Eighteenth Century. 90. 1972. P. 1659-1729.
} 
O sucesso editorial das celebridades medievais de 1790 a 1990, de acordo com o catálogo de História da França da Biblioteca Nacional

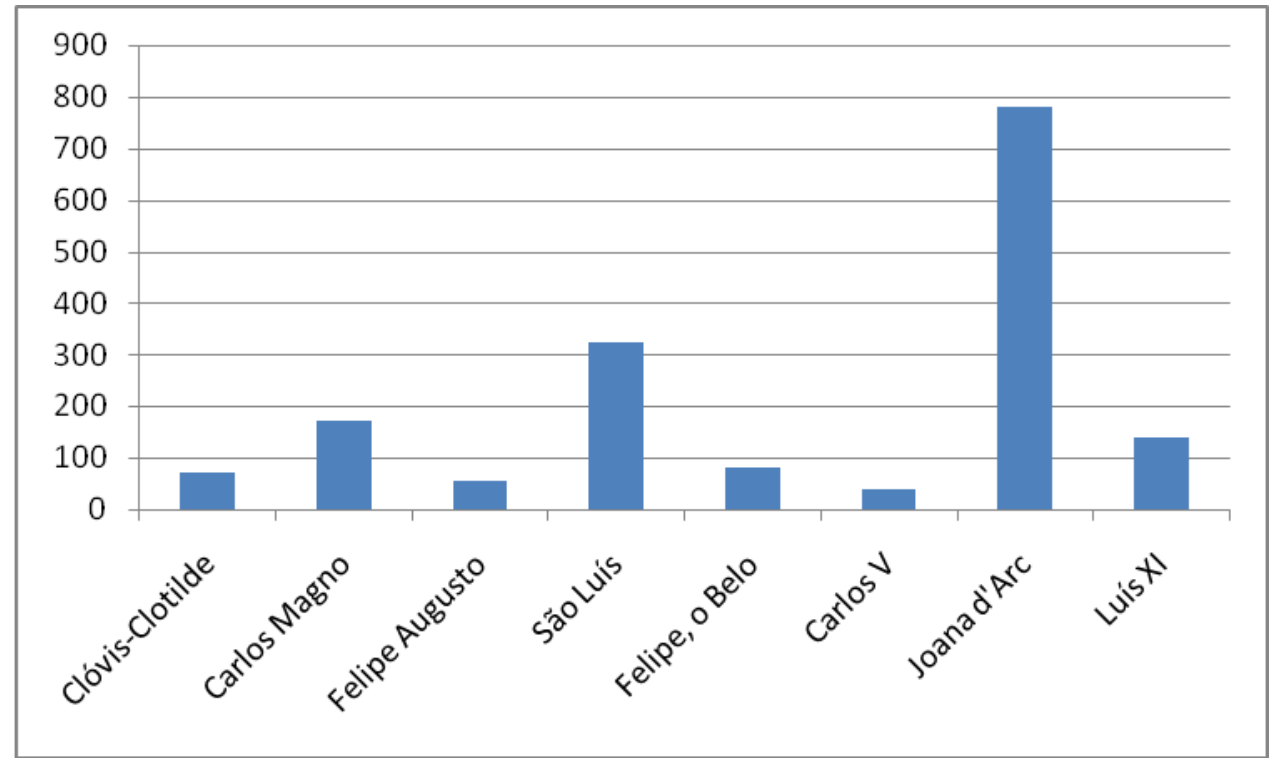

Clóvis-Clotilde 70

Felipe, o Belo

80

Carlos Magno

170

Carlos V

40

Felipe Augusto

55

Joana d'Arc

780

São Luís

325

Luís XI

140

Figura: 16. Fonte: AMALVI, C. Le goût du Moyen Âge. P. 290. Note-se que Amalvi construiu seu gráfico tendo em vista apenas o catálogo da Biblioteca Nacional Francesa, o qual não contempla todas as publicações sobre Joana d'Arc no XIX.

Além disso, a maior parte dos autores aponta para uma mudança da forma como Joana d'Arc é vista pelos escritores oitocentistas, já que ela deixa de ser lembrada como defensora da monarquia e começa a ser vista como uma representante do povo que luta 
contra a tirania absolutista. ${ }^{27}$ Partindo desses dados qualitativos e quantitativos tais autores chegam à seguinte conclusão: a Revolução foi um divisor de águas, existe uma Joana d'Arc antes e outra depois dos acontecimentos de 1789. Para Michelet "Joana é irmã de Danton" ${ }^{\text {28 }}$, e em sua descrição da tomada da Bastilha o ambiente da ação de Joana é revivido:

\begin{abstract}
"Após séculos de distância, os parisienses que assaltam a Bastilha encontram a temeridade dos soldados da Donzela. Uma ideia surge em Paris com o dia e todos veem a mesma luz. Uma luz nos espíritos e em cada coração uma voz: Vá, e tu tomarás a $\operatorname{Bastilha(...),29}$
\end{abstract}

Quicherat, aluno de Michelet e responsável pela edição dos processos de Joana no século XIX, também compartilha da ideia de que só a Revolução enquanto patrocinadora da emancipação do povo pôde transformar a história de uma simples camponesa em uma tradição. Para ele só "a experiência das revoluções permitiram captar a beleza de tal história." ${ }^{30}$

Mas sabemos que a Revolução Francesa não é vista como um momento chave para se compreender apenas a historiografia de Joana d'Arc. Deparamo-nos frequentemente com essa concepção "prometeniana"31 da Revolução, que é interpretada como momento fundador e propagador de ideias, instituições e conceitos políticos tais como liberalismo, conservadorismo, esquerda, direita, etc. A Revolução, lembrando a interpretação clássica de François Furet, pensa a si mesma como evento fundador, um

\footnotetext{
${ }^{27}$ KRUMEICH, G. Jeanne d'Arc à travers l'histoire. Albin Michel, 1993.; GAUCHET, M. "Les Lettres sur l'histoire de France" d'Augustin Thierry. L'alliance austere du patriotism et de la science". In: NORA, Pierre. Les lieux de mémoire. Paris: Galimard. 1984. P. 787-850. BEAUNE, C. Jeanne d'Arc. Paris: Perrin, 2004.

${ }^{28}$ MICHELET, J. Histoire de la Révolution française. Ch. VI. Gallimard, 1952. p. 148. Tradução nossa.

${ }^{29}$ Idem, Ch. VII.

${ }^{30}$ QUICHERAT, J. Aperçus nouveaux sur l'histoire de Jeanne d'Arc. Paris, 1850. p. 165. Tradução nossa.

${ }^{31}$ GARCIA, P. "La naissance de l'histoire contemporaine". In: Les courants hitoriques en France. XIXeXXe siècles. Paris: Armand Colin, 2005.
} 
momento oportuno para se criar o melhor dos homens no melhor dos mundos, permeado pelos valores da igualdade, liberdade e fraternidade. ${ }^{32}$

A própria História, nas palavras de Lucien Febvre, nasceu da Revolução que levou o povo a ser seu agente e sujeito ${ }^{33}$. A importância da Revolução Francesa para o momento que viria ser chamado "revolução historiográfica" da década de 1820 , responsável por lançar as bases do que seria a história-ciência centrada na pesquisa arquivística e na análise das fontes, também é colocada por muitos autores ${ }^{34}$. A História moderna teria nascido então para construir um passado comum que explicasse o advento e o significado da ruptura revolucionária.

"a construção de uma memória coletiva aparece como uma necessidade prioritária, um contra-poder às inércias das diferenças, um contraponto aos mosaicos de modos de viver e de morrer; a obrigação absoluta de compilar as memórias locais no fundo comum de uma cultura nacional e de fazer de todos os 'filhos de 89'." 35

A História e o historiador assumem então um posto fundamental, uma vez que se tornam os responsáveis por atender às demandas identitárias da sociedade:

"A precocidade da constituição de um Estado-Nação, confrontada com o caráter radical da ruptura revolucionária de 1789, constitui o húmus sobre o qual essa autoridade [da história] pôde ser exercida. A nação pôde então beneficiar-se de uma verdadeira transferência de sacralidade, e o historiador encarregou-se de enraizar o sentimento nacional da população."36

\footnotetext{
${ }^{32}$ FURET, F. Pensar a Revolução Francesa. Lisboa: Edições 70, 1998. A Revolução Francesa em debate. Bauru: Edusc, 2001. e "Ancien Régime”. In: NORA, Pierre. Les lieux de mémoire. Paris: Galimard. 1984.

${ }^{33}$ FEBVRE, Lucien. Michelet e a Renascença. São Paulo: Scritta, 1995.

${ }^{34}$ DOSSE, F. A história à prova do tempo: da história em migalhas ao resgate do sentido. São Paulo : Editora da Unesp, 2001. GARCIA, P. op. cit. GAUCHET, M. op. cit. HARTOG, F. Le XIXe siècle et l'histoire. Le cas Fustel de Coulanges, Paris: Presses Universitaires de France, 1988.

${ }^{35}$ NORA, P. "De la nation à la République". In: NORA, P. op. cit. p. 560. Tradução nossa.

${ }^{36}$ DOSSE, F. op. cit. p. 11.
} 
Tais afirmações, porém, não podem ser feitas sem questionamentos e sem atentar para o fato de ser apenas aparente a coincidência da construção de uma nova imagem de Joana d'Arc e o nascimento da historiografia moderna. Mas o que dizer sobre as flagrantes contradições do período revolucionário em relação a ambos os fenômenos?

Voltemos ao caso da Donzela de Orléans. Durante a Revolução, Joana era vista com desconfiança e certos episódios demonstram uma falta de consenso em relação ao que ela representava. Em 1792 os revolucionários exigem do conselho Municipal de Orléans a destruição da estátua de Joana, vendo nela um símbolo do feudalismo e da tirania monárquica. $\mathrm{O}$ conselho se recusa a acatar essa ideia, mas a administração departamental ratifica a ordem e exige a fundição da estátua para a produção de canhões. Curiosamente, junto com essa ordem é exigido que "para se conservar a memória do monumento da Donzela, um dos canhões terá o nome de Joana d'Arc, chamada Donzela de Orléans." ${ }^{37}$ Na cidade de Rouen, onde Joana foi morta, a fonte do mercado que era decorada com seu retrato, foi salva da destruição devido à intervenção do Conselho Municipal daquela cidade. Eles ordenaram apenas que se apagassem as inscrições monarquistas da fonte. Já a tradicional "Festa da Donzela", celebrada em Orléans quase sem interrupção desde 1432, foi suprimida em 1793 não tendo sido retomada durante todo o período revolucionário ${ }^{38}$.

A relação História e Revolução também não poderia ter sido mais controversa. A formação do conceito de Antigo Regime se deu nesse momento como uma condenação do passado em bloco, com o desejo de fazer "tábula rasa do passado". "Desde setembro

\footnotetext{
${ }^{37}$ QUICHERAT, J. Procès de condamnation et de réhabilitation de Jeanne d'Arc. França: Jules Renouard et Cie, 5v., 1861.t. V, p. 243. Tradução nossa.

38 KRUMEICH, op. cit.
} 
de 1789 a denominação Antigo Regime se espalha e o termo significa que o passado está definitivamente abolido." 39 A opção por um novo calendário talvez seja um dos exemplos mais claros de como o passado havia sido rejeitado pela Revolução Francesa. Essa rejeição se exprime ainda na nova referência temporal: Ano I da Lberdade, Ano I da República, etc.

Reconhecer o desejo de rejeição do passado por parte dos revolucionários, não sinifica negar suas referências a outros períodos, em especial o da Antiguidade. Entretanto, tal época é relembrada tendo em vista a qualidade atemporal atribuída às suas instituições políticas que teriam promovido uma liberdade arquetípica na Atenas democrática e na Roma republicana. Afirmar a superioridade desses dois períodos históricos, no entanto não impedia a condenação do passado, uma vez que tais eras foram valorizadas exatamente por aquilo que tinham de sincrônico com o que a França desejava se tornar.

De fato a tradição Iluminista à qual pertencem os princípios norteadores da Revolução Francesa rejeita a História como categoria referencial e explicativa da sociedade. Conhecemos a máxima de Rousseau no início de seu Discurso sobre as Origens da Desigualdade entre os Homens: "Comecemos, pois, por descartar todos os fatos" ${ }^{\natural 0}$. Essa noção está presente no contexto revolucionário e se expressa através de conhecidas lideranças do período, como na seguinte fala do convencional Rabaut de Saint-Étienne: "A História não é nosso código"41.

Existia, porém, todo um aporte material remanescente do período anterior pressionando os contemporâneos da Revolução como se esperasse deles uma resposta.

\footnotetext{
${ }^{39}$ GARCIA, P. op. cit. p. 17. Tradução nossa.

${ }^{40}$ ROUSSEAU, J-J. A origem da Desigualdade entre os homens. São Paulo: Escala, 2007. p.28

${ }^{41}$ Citado em GARCIA, P. op. cit, p. 20. Tradução nossa.
} 
Obviamente temos nesse período a destruição de monumentos, igrejas, palácios que, muitas vezes, era patrocinada pelo próprio governo. Desde 14 de agosto de 1792 , o legislativo decreta que os monumentos "restos da feudalidade deveriam ser, sem demora, destruídos". Tinha-se como objetivo apagar tudo aquilo que trazia a assustadora lembrança dos reis. Tal gesto era, como nos lembra Garcia, fruto de "tendências iconoclastas que consideravam a destruição como um gesto de purificação." ${ }^{42}$

Nesse clima de se apagar os vestígios do passado, parece contraditório que em 1790 a constituinte tenha criado os Arquivos Nacionais e departamentais. A ideia que norteou essa decisão, no entanto, era bem prática, pois em tais arquivos são colocados os títulos das propriedades que se tornaram bens nacionais. Ao mesmo tempo, a massa de documentos herdada dos antigos arquivos e bibliotecas dos nobres se transformaram em um problema: aquele amontoado de papéis merecia a atenção daqueles que começavam a criar um mundo novo, a partir do zero?

Condorcet, em discurso de 10 de junho de 1792, disse:

"É hoje o aniversário desse dia memorável em que a Assembleia Constituinte ao destruir a nobreza colocou a última pedra para a construção do edifício da igualdade política. É hoje que, na capital, a Razão queima aos pés da estátua de Luís XIV esses imensos volumes que atestavam a vanidade dessa casta. Outros vestígios subsistem ainda nas bibliotecas públicas, nas câmaras de contas, nos capítulos e nas casas dos genealogistas. Deve-se unir o conteúdo desses depósitos para uma destruição comum. Não guardeis às custas da nação essa ridícula esperança que parece ameaçar a igualdade."43

A lei de 7 do messidor do ano II (25/06/1794) tenta resolver essa questão. Ela amplia a competência dos arquivos e institui uma comissão encarregada de separar os

\footnotetext{
${ }^{42}$ GARCIA, P. op. cit., p. 21.

${ }^{43}$ Disponível em: http://www.assemblee-nationale.fr/histoire/7ed.asp. Acesso: maio, 2010. Tradução nossa.
} 
documentos recolhidos e destruir tudo o que não pertencesse à classe dos monumentos históricos, daquilo que tinha a marca da servidão. Contudo se manifesta nesse momento uma atitude de conservação e há a necessidade de se definir quais documentos tem um valor histórico. Essa lei, ao definir os princípios fundamentais da organização dos arquivos, determina ainda que o acesso a eles será livre para todos os cidadãos.

É também durante Revolução que se cria o termo vandalismo pelo abade Grégoire, em 1793. Afinal, só um bárbaro poderia atentar contra o patrimônio comum. Além disso, ele dirá que é imprescindível a preservação do patrimônio, isto é, dos bens herdados coletivamente do passado.

\begin{abstract}
"A convenção nacional sabiamente ordenou a destruição de tudo aquilo que tem o sinal da monarquia e da feudalidade (...). A essa medida, ela deve juntar outras, para assegurar a conservação das inscrições antigas as quais o tempo respeitou a existência. Os decretos referentes a essa questão parecem insuficientes e não inspiram ao cidadão tanto horror em relação a esse vandalismo que só conhece a destruição. Os monumentos antigos são medalhas sob outra forma, eles devem ser conservados em sua totalidade; e que homem sensível não estremece ao ver bater o martelo sobre as antiguidades de Orange ou de Nîmes? Quanto àquelas da Idade Média e dos tempos modernos, cujas inscrições não apresentam nada contrário aos princípios da liberdade e da igualdade, devem ser igualmente conservadas; elas completam sempre os fatos dos quais os arquivos são depositários; elas fixam as épocas da História; destruí-las seria uma perda (...) Reprimireis sem dúvida a barbárie contra-revolucionária que desejava nos apavorar e desonrar. "44
\end{abstract}

Após constatar a relação conturbada dos revolucionários com a história, como insistir na ideia de filiação? Como um movimento embebido nos valores iluministas questionadores do valor da história como forma de conhecimento pôde conceber as bases para que se criasse um lugar de autoridade para o discurso histórico? Tal

\footnotetext{
${ }^{44}$ GRÉGOIRE. Rapport sur les inscriptions des monuments publics. 22 Nivôse an II. (10/01/1794.) Disponível em: http://gallica.bnf.fr/ark:/12148/bpt6k484940/f3.image. Acesso: 10/09. Tradução nossa.
} 
questionamento se liga imediatamente a nosso objeto de estudo, uma vez que o século das Luzes foi extremamente crítico e irônico também em relação à Joana d'Arc, sendo o maior exemplo a opinião de Voltaire, para quem ela era uma "infeliz idiota" então continuar, sem um exame mais acurado, relacionando tão definitivamente Revolução Francesa e Joana d'Arc?

Vejamos, em primeiro lugar, como a historiografia explica o nascimento da História após um longo período de rejeição do passado.

Ceri Crossley ${ }^{46}$ esclarece que no período da Restauração havia, por parte daqueles que defendiam os pressupostos revolucionários, a necessidade de se provar que a Revolução não era uma aberração. Assim, essa discussão no campo político era levada para o campo da História. Os chamados ultra-realistas queriam mostrar que a Revolução era um acontecimento satânico, defendendo assim o restabelecimento "do trono e do altar”. Já os liberais, tentavam distinguir 1789 de 1793, colocando a fase do Terror em xeque, procurando provar que esse período não foi um desdobramento necessário de 1789. Sendo assim o interesse pela história nacional viria para responder à questão: por que ocorreu a Revolução ${ }^{47}$

Garcia, da mesma forma, percebe que após a queda de Napoleão, a interpretação da Revolução Francesa torna-se central:

"Como, com efeito, integrar na história da França essa ruptura reivindicada que repentinamente revogou instituições centenárias? Ela é um acidente, um parêntese que se podia

\footnotetext{
45 "Et une malheureuse idiote, qui avait eu assez de courage pour rendre de très grands services au roi et à la patrie, fut condamnée à être brûlée par quarante-quatre prêtres français qui l'immolaient à la faction de l'Angleterre". VOLTAIRE. "Jeanne d'Arc, dit la Pucelle". In: Dictionaire Philosophique. Cosse et Gaultier-Laguionie, 1838. p.133

${ }^{46}$ CROSSLEY, Ceri. French historians and romanticism : Thierry, Guizot, the Saint-Simonians, Quinet, Michelet. London; New York : Routledge, 1993.

${ }^{47}$ GAUCHET, op. cit.
} 
fechar, como defendem os ultras, ou o produto do movimento da sociedade, a consequência de uma evolução necessária e irreversível que todo governo deve levar em conta, como pensam seus adversários liberais?"48

Isso só poderia ser explicado se esses fatos fossem colocados em perspectiva com o passado. Augustin Thierry confessa que, em 1817, quando queria contribuir para o triunfo das opiniões constitucionais, vai procurar nos livros de história os argumentos para apoiar suas crenças políticas ${ }^{49}$. Em análises posteriores, Thierry dirá que “as revoluções municipais na Idade Média" prefiguram as "revoluções constitucionais dos tempos modernos."

Gauchet também afirma que essa nova consciência do passado veio de um exercício de se pensar a ruptura de 89 à luz de sua reinserção na continuidade de uma longa sucessão de séculos. Partindo dessas afirmações, inserimos nesse mesmo processo a construção de uma nova imagem de Joana d'Arc que também irá se pautar por uma necessidade da construção de uma memória nacional, a partir de uma História que busca em alguns personagens históricos (Vercigentorix, Carlos Magno, Étienne Marcel, além dela mesma) elementos com os quais pudesse identificar um momento primordial de nascimento e/ou luta pela liberdade. O que resta, no entanto é compreender como e por que se saiu de uma situação de renegação do passado para sua supervalorização. Acreditamos que só a partir dessa resposta teremos uma maior clareza para compreender a nova imagem criada para Joana d'Arc no século XIX.

\footnotetext{
${ }^{48}$ GARCIA, op. cit. p. 11. Tradução nossa.

${ }^{49}$ GAUCHET, op. cit, p. 789.

${ }^{50}$ HARTOG, op. cit., p. 234. Tradução nossa.
} 


\section{2- Ressignificação e conservação}

O seguinte lamento de Dacier pode nos ajudar a encontrar pistas para pensamos esses problemas:

"A história da Idade Média e a diplomacia são, de todos os ramos da literatura, os que mais devem sofrer as devastações da Revolução. A supressão das ordens monásticas e das academias colocou em sono os dois centros vivos em torno dos quais se concentravam os estudos: os estudos das antigas chartes e dos manuscritos de diferentes séculos." 51

Esse autor, como helenista, expressa sua preocupação com as consequências da ideia de ruptura total com o passado. A nosso ver, essa tendência de conservação, presente na obra de Dacier, reflete a necessidade de se posicionar diante de um problema evidente: tudo o que pertencia ao passado, chamado genericamente de Antigo Regime, deveria realmente ser destruído? O desejo de se fundar uma sociedade baseada na ideia de ruptura radical a partir da qual seria criado um mundo de liberdade teria que estar necessariamente atrelado à destruição de toda referência temporal?

Como se pode observar sem levar em conta o impasse destruição versus conservação é impossível compreender de que forma o discurso político, principalmente a partir da Restauração, tem na História seus principais argumentos propiciando a elevação dessa área do conhecimento à categoria de ciência, tal como desejavam os historiadores metódicos do século XIX. É ainda a partir desse problema que devemos procurar o lugar ocupado pela Idade Média que será alvo de interesse progressivo

\footnotetext{
${ }^{51}$ Apud GARCIA, op. cit., p. 37. Tradução nossa.
} 
também a partir da queda do Império e mais especificamente é esse questionamento que nos permite desvendar as novas atribuições que receberá Joana d'Arc no século XIX.

Joana, enquanto parte desse passado em relação ao qual se reivindicava uma ruptura, também sofrera os ataques da Revolução que se configuraram claramente nas tendências iconoclastas em relação às suas estátuas. Entretanto, ela receberá uma atenção progressiva e será usada por esse mesmo discurso político que vai reivindicar a História como autoridade para seus argumentos. A propósito dos percalços que envolveram o processo que foi da destruição da abadia de Saint-Denis no contexto revolucionário à sua posterior reconstrução, Jean-Michel Leniaud questiona: “(...) como é que um patrimônio ferido da mesma condenação de instituições que até então o haviam detido, pôde progressivamente ser recuperado por novas instituições que lhe eram totalmente estranhas?"52 Dessa forma, percebe-se que o mesmo processo que originou a valorização da história, a criação do patrimônio nacional e a necessidade de sua preservação propiciou tal interesse por Joana d'Arc e levou a epopeia da Donzela de Orléans a ser considerada uma prefiguração da Revolução Francesa. Mas que processo fundamenta ambos os fenômenos?

Em 1803, a Municipalidade de Orléans pede ao então Primeiro Cônsul, Napoleão Bonaparte, que permita a construção de uma nova estátua de Joana d'Arc naquela cidade para substituir a que fora destruída em 1792. Bonaparte se mostra muito aberto a essa proposta e declara:

"A deliberação do Conselho de Orléans me agrada muito. A ilustre Joana d'Arc provou que não há milagre que o espírito do povo francês não possa operar quando a independência nacional está ameaçada. Unida, a nação francesa jamais foi vencida, mas

\footnotetext{
${ }^{52}$ LENIAUD, J. M. “O patrimônio recuperado. O exemplo de Saint-Denis.” In: RIOUX, J- P e SIRINELLI, J-F. Para uma história cultural. Lisboa: Estampa, 1998. p. 335-348. p. 336.
} 
nossos vizinhos abusando da franqueza e da lealdade de nossa personalidade, semeiam frequentemente entre nós conflitos dos quais nascem as calamidades da época em que venceu a heroína e todos os desastres que se relacionam à nossa história" ${ }^{\text {. }}$.

Ainda nesse mesmo ano, Napoleão aprova o pedido do bispo de Orléans para que se voltasse a celebrar a data da libertação da cidade por Joana d'Arc, dizendo que era louvável a tentativa do bispo de fazer com que a religião colaborasse com tudo o que pudesse trazer honra à nação francesa.

Porém não foi só em relação à Joana d'Arc que Napoleão tomou um posicionamento que poderia ser questionável do ponto de vista dos revolucionários mais radicais. Sabemos que ao contrário de determinar a destruição de prédios, monumentos ou outras construções que pudessem relembrar o execrado Antigo Regime, Napoleão faz de muitos deles sua moradia e/ou locais de exercício do poder como quando em 1800 instala-se no Palácio de Tulleries. Depois de se tornar imperador, ele frequentemente fez reuniões, se hospedou por longos períodos e instalou seus familiares no Palácio de Versailles. Bonaparte atacava as ondas de destruição aos palácios e fazia questão de mostrar seu descontentamento em relação a alguns eventos, como o ataque de 1792 ao Palácio de Tulleries durante o qual até mesmo mulheres mutilavam cadáveres. Para Napoleão, isso fazia parte dos excessos da Revolução que podiam ter levado a França à anarquia. Sabemos que foi também Napoleão o responsável por tornar as relações entre Estado e Igreja mais amenas nesse período ao anistiar muitos membros do clero e tomar outras medidas conciliadoras como consta na Concordata de 1801. Na restauração da abadia de Saint-Denis, Napoleão teve papel fundamental, não apenas por ter lançado a ideia de sua recuperação material em 1806, mas por promover uma espécie

\footnotetext{
${ }^{53}$ Citado em QUICHERAT, J. Procés de condenation ... p. 244. Tradução nossa.
} 
de restauração, pois desejou ser enterrado naquela que sabidamente era a necrópole das dinastias reais francesas e ordenou que seu túmulo fosse construído ali.

Tais características do período napoleônico nos permitem afirmar que aquela visão da ruptura total com o passado, já questionada no período inicial da Revolução, mas vista antes como uma necessidade para a construção dos ideais revolucionários, se transforma em uma necessidade de ressignificar o passado ao invés de renegá-lo totalmente. Isso nos permite afirmar que se trata, sobretudo, de uma atitude conservadora já presente em opiniões como a do abade Grégoire, que passa a questionar a validade de uma ruptura total devido ao receio de uma perda de referências.

Essa postura de ressignificação do passado estará presente, sem dúvida, na literatura romântica. Em Notre Dame de Paris, de 1831, a catedral gótica, que para o século das Luzes representava o obscurantismo e o misticismo medievais, torna-se não apenas o cenário principal da narrativa, mas o fundamento da obra. Quasímodo, aparentemente um monstro, é o personagem da história que possui os melhores sentimentos. Mas não deixa de ser uma força bruta, incapaz de se orientar e conhecer seus próprios desejos. Christian Amalvi constata que Victor Hugo vê nesse personagem um símbolo do homem medieval, um representante do povo que marchava rumo à sua libertação. "Mas paciência, ainda alguns séculos de amadurecimento e esse povo ao invés de se manter de maneira estéril na catedral, vai se voltar decididamente contra o símbolo do poder real, a Bastilha." ${ }^{, 54}$

Nesse romance, os processos de ressignificação se dão ainda de outra forma. Prédios como a Bastilha aparecem com descrição de detalhes, assim como lugares de poder dos tempos de Louis XI:

${ }^{54}$ AMALVI, C. op. cit. p. 27. Tradução nossa. 
"Se pudéssemos, nós, homens de 1830, nos envolvermos no pensamento desses parisienses do século XV e entrar com eles aos safanões, acotovelados, repelidos nessa imensa sala do Palácio [de justiça destruído no incêndio de 1618], tão acanhada em 6 de janeiro de 1492, o espetáculo não seria sem interesse, nem sem charme, e apenas teríamos diante de nós, coisas tão velhas, que nos parecem totalmente novas." 55

É sintomático o fato de Victor Hugo ter se expressado de maneira tão veemente contra o vandalismo em Guerre aux démolisseurs $!^{56}$. Condenando a destruição da torre Louis d' Outremer na cidade de Charleville ele denuncia:

"Assim, para derrubar a torre de Louis de Outremer, quase contemporânea das torres romanas da antiga Bibrax, para fazer o que não fizeram nem carneiros, nem escorpiões, nem catapultas, nem machados, nem engrenagens, nem bombardeios, (...) nem trovões, nem tempestade, nem batalhas, nem o fogo dos homens, nem o fogo do céu, foi suficiente o século XIX. Maravilhoso progresso! Uma pena desfilou quase aleatoriamente em uma folha de papel (...). Pena perversa de um conselho municipal de vigésima categoria que formula defeituosamente as decisões imbecis de um grupo de camponeses! (...) Pena que comete erros em francês! Pena que, certamente, traçou mais cruzes do que assinaturas abaixo da ordem inepta! $" 57^{\circ}$

A conservação desses monumentos torna-se um imperativo moral a partir de uma nova consciência patrimonial. Temos nesse momento a ampliação da ideia de patrimônio nacional ao mesmo tempo em que se criam na França instituições de cunho patrimonial que visavam a preservação de documentos históricos. Desde a década de 20, essa preocupação se faz presente. A École des Chartes é criada em 1821. Em 1833 nasce a Sociedade de História da França "dedicada a publicar os documentos originais relativos à nossa história nacional e a difundir [...] o conhecimento dos trabalhos dispersos e ignorados." Presidida até 1866 por Barante, um dos mais conhecidos

\footnotetext{
${ }^{55}$ HUGO, V. Nossa Senhora de Paris. Porto: Lelo, 1952. P. 4.

${ }^{56}$ HUGO, V. Guerre aux démolisseurs! Artigo inicialmente publicado em 1829 na Revue de Paris e republicado em 1832 na Revue des deux mondes, t. V. Tradução nossa ${ }^{57}$ Idem, p. 3.
} 
biógrafos de Joana d'Arc, em 25 anos de existência publica 71 volumes (dentre os quais os cinco volumes dos processos de Joana, que se tornam uma de suas maiores realizações). Em 1844 a Societé é a mais importante sociedade de intelectuais da França, com 400 membros. Em 1834 é criado o Comitê dos trabalhos históricos e científicos. Nesse período, conhecido como a Monarquia de Julho, estabelecida após a Revolução de 1830, os historiadores são convocados ao trabalho. Guizot é feito Ministro do interior em 1830 e, mais tarde, em 1836, Ministro da Instrução Pública. Thierry, em 1835, é encarregado de recolher os monumentos inéditos do terceiro estado com a ajuda dos chartistas, sendo que o primeiro dos três volumes dos Monumentos inéditos foi publicado em 1850. Em 1830, cria-se o cargo de "Inspetor dos monumentos históricos”, que em 1834 é assumido por Proper Merimée. Em 1837, o ministério do interior passa a contar com uma comissão dos monumentos históricos encarregada de preservar os monumentos e os restaurar. O Museu Thermes de Cluny também é fundado nesse período e recebe as coleções medievais.

Ao mesmo tempo em que se criam essas instituições de memória, nasce uma preocupação com a forma como os documentos e monumentos devem ser tratados e analisados. Como se deve escrever essa história nacional? Como trabalhar esses documentos? A partir de que critérios? Quais os métodos? Como analisá-los? Tais questões levam ao nascimento de críticas dentre os próprios historiadores que questionam os métodos com os quais esses documentos são trabalhados. Em 1829, Benjamim Guérard critica a produção histórica nascente:

"Depois dos trabalhos dos beneditinos (...) não houve nenhuma obra verdadeiramente progressiva para a história de nosso país. Abandonando a rota penosa e segura que esses sábios religiosos seguiram, os historiadores que vieram depois deles, ao invés de avançarem, se movem à esquerda e à direita, ou ficam atrás e não descobriram nada, nada conquistaram do passado: eles se 
contentaram com as riquezas que acumularam durante um século e meio, as ilustres congregações de Saint Maur e de Saint Vanné e, sem pretender lhes suceder na tarefa imensa à qual se impuseram e que deixaram imperfeita, eles só fizeram remoer e retornar aos antigos materiais." 58

Tais contradições entre os objetivos a serem atingidos e os meios empregados levam a afirmações como a de Thierry: "nós ainda não temos História da França. (...) nós somos os primeiros a compreender o passado" ${ }^{\text {.59 }}$. Na verdade essas questões que envolvem o período são notadamente marcadas pela ideia de ressignificação, ou seja, nas palavras de Guérard percebe-se que, sem dar um novo sentido a essa massa documental, sem transformá-los em uma base para a construção de uma identidade nacional, eles não tinham razão de ser.

Thierry via a mesma necessidade de ressignificar o passado uma vez que as abordagens dos eruditos do XVII e XVIII não faziam mais sentido para ele. Essa necessidade era defendida com base na ruptura revolucionária. Para ele foram as convulsões políticas revolucionárias que levaram os historiadores de sua geração

“(...) a ver o fundo das coisas sob as crônicas, a tirar dos escritos dos beneditinos o que esses homens sábios não puderam ver, ou que viam de forma parcial e incompleta, sem nada concluir, sem medir seu tamanho. Faltava-lhes inteligência e o sentimento das grandes transformações sociais. Eles estudaram cuidadosamente as leis, os atos públicos, as fórmulas judiciais, os contratos privados, eles discutiram, classificaram, analisaram os textos, fizeram uma separação do verdadeiro e do falso com uma enorme sagacidade; mas o sentido político de tudo isso, o que há de vivo para a imaginação sobre essa escrita morta, a própria vida da sociedade e de seus elementos diversos (...) lhes escapa e disso resultam os vazios e a insuficiência de seus trabalhos."

\footnotetext{
58 Artigo publicado no Universel, 15-19 de dez. de 1829 citado em: LE POTTIER, Jean. Histoire et erudition. Recherches et documents sur l'histoire et le rôle de l'érudition médiévale dans la historiographie française au XIXe siècle. Tese. École des Chartres, 1979. p. 797. Tradução nossa.

${ }^{59}$ APUD GAUCHET, M. op. cit. p. 787. Tradução nossa.

${ }^{60}$ THIERRY, A. Lettres sur l'histoire de France. Paris, 1852. Tradução nossa.
} 
Thierry expressa o desejo de continuar os trabalhos desses eruditos a partir de novos parâmetros dados pelas mudanças sociais e pela tomada de consciência em relação a elas, promovida pelos acontecimentos revolucionários. Em suas análises documentais ele via nos movimentos de resistência dos oprimidos em relação à arbitrariedade feudal um anúncio e preparação da emergência do $3^{\circ}$ estado.

"Nós somos filhos do terceiro estado; o terceiro estado saiu das comunas, as comunas foram o asilo dos servos, os servos foram os derrotados pela conquista. Assim de fórmula em fórmula, através do intervalo de quinze séculos, nós somos conduzidos ao termo extremo da conquista.",61

De fato a massa documental herdada do Antigo Regime, antes lixo, “(...) uma massa enorme de papéis do Estado sem valor" ${ }^{20}$, merecedora da fogueira, numa atitude de purificação que se manifestava na rejeição pelos documentos que teriam testemunhado a opressão do povo francês no contexto feudal e absolutista, passa a ser considerada uma fonte de possibilidades múltiplas para se localizar o nascimento do povo e da nação francesa e para identificar o momento em que os dois se aproximaram, como por exemplo, na Guerra dos Cem Anos a partir das ações de Joana d'Arc, e em que momentos foram afastados não por seus próprios esforços, mas devido ao império da tirania. Assim, passa-se a afirmar que foram os eruditos do Antigo Regime que não souberam de fato analisar essa documentação. Mas a verdade é que essa nova produção de conhecimento esperada deve diferir do conhecimento dos antiquários, para ressignificar aquilo que a França não teve a coragem de destruir. Trata-se da grande contradição, apontada por François Furet, entre o discurso da ruptura revolucionária e

\footnotetext{
${ }^{61}$ THIERRY, A. "Dix ans d'études historiques". In: Oeuvres complétes. Paris: Garnier: 1867. p. 505. Tradução nossa.

${ }^{62}$ FUETER, E. Histoire de l'historiographie moderne. 1919. Tradução nossa.
} 
aquilo com o que de fato se rompeu. Na década de 1820 aprofundam-se as discussões sobre a tese das "duas revoluções" que opunha os movimentos de 1789 e de 1793 . A partir de então se assiste a uma condenação progressiva do período do Terror e a propagação de sua imagem como um período sombrio da Revolução, algo como um interlúdio de anarquia e violência, ideia predominante nos discursos até 1848. Há uma tentativa de dissociar os anos de governo do Comitê de Salvação Pública dos nobres ideais, verdadeiros responsáveis pelo movimento revolucionário. O discurso histórico sem dúvida será o responsável por alimentar essa imagem, renegando o Terror como consequência lógica e inevitável dos acontecimentos de 1789. Ou seja, o período que mais manifestou a condenação do passado com atitudes práticas em relação a isso passa a sofrer um ataque, já que a opção posterior de tornar a história uma referência para a identidade nacional foi adotada como política de estado numa atitude conservadora.

As seguintes palavras de Musset exprimem a relação conflituosa do homem francês oitocentista com a noção de tempo que, a nosso ver, pode ser identificada nas questões que envolviam a História, Joana d'Arc e sua ressignificação:

"Três elementos dividem então a vida que se oferece aos jovens: atrás deles um passado destruído para sempre se agitando ainda em suas ruínas, com todos os fósseis dos séculos de absolutismo; diante deles a aurora de um imenso horizonte, os primeiros clarões do futuro; e entre esses dois mundos... alguma coisa comparável ao Oceano que separa o velho continente da jovem América, alguma coisa vaga e flutuante, um mar agitado e cheio de naufrágios, atravessado de tempos em tempos por uma vela branca distante ou por algum navio soprando um forte vapor; o século presente, em uma palavra, que separa o passado do futuro, que não é nenhum nem outro e que é os dois ao mesmo tempo e em que não se sabe, a cada passo que se dá, se anda-se sobre uma semente ou sobre uma sucata. "63

\footnotetext{
${ }^{63}$ MUSSET, A. La confession d'un enfant du siècle. Paris: Charpentier, 1867. p. 7. Romance publicado originalmente em 1836. Tradução nossa.
} 
A escolha da sociedade não foi renegar tais sucatas, mas dar um novo sentido a elas tentando, sobretudo, relacioná-las aos ideais revolucionários. Nessa busca de ressignificação do passado, descobre-se, por exemplo, que o povo não é tão novo assim. Encontram-se então Joana d'Arc e Étienne Marcel que, por exemplo, é qualificado como o "Danton do século XIV"64. O camponês medieval Jacques Bonhomme passa a ser tido como o símbolo da revolta campesina e Barante chega a propor parentesco entre ele e Joana d'Arc: "Bonhomme e sua família eram bons e verdadeiros franceses detestando até a morte os ingleses e os borguinhões, exterminando-os tanto quanto era possível. (...) Joana d'Arc, a Donzela de Orléans, era prima de Jacques Bonhomme.” 65.

"Coisas tão velhas, que nos parecem totalmente novas.” A sentença de Victor Hugo sintetiza muito bem o processo de ressignificação ao qual o passado na França foi submetido após o discurso revolucionário insistir na ideia de ruptura e inauguração de um mundo novo. Para Leniaud ${ }^{66}$ se tratava de um posicionamento diante do seguinte dilema: como restaurar sem Restaurar? A nosso ver o grande interesse pela figura de Joana d'Arc no século XIX, nascido nesse momento crucial, relaciona-se intimamente a esse processo mais abrangente e de tal forma marcante que definiu o grande sucesso desse personagem a partir de então.

Uma das grandes realizações do século XIX em relação às pesquisas sobre Joana d'Arc foi, sem dúvida, a edição de seus processos de condenação e de anulação da condenação por Jules Quicherat entre 1841 e 1849. Como vimos, pela primeira vez os processos têm sua publicação integral e em conjunto com outras fontes concernentes à história da Donzela, como crônicas e poesias. Mas a insistência na originalidade do

\footnotetext{
${ }^{64}$ AMALVI, C. op. cit.

${ }^{65}$ BARANTE, P. "Jacques Bonhomme". In: 290.Tradução nossa. Mélanges historiques et litterares II. 1835. p.

${ }^{66}$ LENIAUD, J. M. op. cit.
} 
século XIX baseada na ideia da ruptura trazida pela Revolução Francesa merece ser questionada quando nos voltamos às evidências. Clément de L'Averdy (1724-1793), antigo conselheiro do Parlamento de Paris, após sua aposentadoria em 1768, dedica-se à erudição, torna-se membro da Academia de Inscrições e começa a trabalhar com os processos de Joana d'Arc. Ele privilegia em suas pesquisas os manuscritos originais e atas dos processos, fazendo uma verdadeira exumação da documentação concernente à Joana que origina duas publicações: o Mémorial lu au comité des manuscrits concernant la recherche à faire des minutes originales des différentes affaires qui ont eu lieu par rapport à Jeanne d'Arc, appelée communément la Pucelle d'Orléans de 1787, e o Notices et extraits des manuscrits de la Bibliothèque du roi, lus au comité établi par sa Majesté dans l'Académie royale des Inscriptions et Belles Lettres, em 1790. Em ambas as obras seu objetivo principal é divulgar a localização desses documentos, além de apresentar genericamente seu conteúdo. É interessante notar que, mesmo antes da chamada "revolução historiográfica" da década de 1820, L’Averdy faz um trabalho primoroso de inventariamento e comparação dos diversos manuscritos, além de se preocupar em demonstrar seus métodos para garantir a autenticidade das fontes. O Notices et extraits, por exemplo, é acompanhado de questões e problemas através dos quais o autor tenta compreender a condenação de Joana d'Arc, analisando o procedimento do tribunal inquisitorial como a escolha dos juízes, a atuação de Cauchon, a influência dos ingleses, tudo, segundo ele, dentro das normas da imparcialidade crítica. Pode-se dizer que com os trabalhos de L'Averdy os processos de Joana puderam ocupar um destaque progressivo, uma vez que, até então, não existia nenhum trabalho que tinha se ocupado em noticiar, como o próprio nome já diz, a localização desses manuscritos, seu conteúdo, seus problemas, sua acessibilidade. Quicherat não deixou de reconhecer a importância de L'Averdy para a historiografia joânica em matéria de 
fontes: "Nosso século lhe deve o fato de ter recebido pronta toda a matéria para tratar da história da Donzela." 67

A verdade é que, no lugar de proporcionar um avanço dos trabalhos com uma possível edição e publicação dos processos como tudo indicava, a Revolução impediu sua continuidade já que l'Averdy, como muitos políticos que participaram dos governos de Luís XVI, foi guilhotinado em 1793. Além disso, a própria obra de L'Averdy levanos a relativizar a importância do momento pós-revolucionário para essa valorização dos processos de Joana d'Arc como base principal para narrar sua história. Sua preocupação em encontrar manuscritos dispersos era inegável e no Notices ele relata vários episódios em que se vê um esforço, não apenas seu como também de muitos outros nobres, para identificar e localizar com precisão todos os manuscritos existentes relacionados aos processos de Joana. O barão de Breteüil, por exemplo, pediu ao rei que ordenasse pesquisas com o objetivo de encontrar as minutas francesas e latinas dos dois processos, fontes essenciais a serem comparadas a eles.

Essa atividade, depois da Revolução, da mesma forma que muitos prédios administrativos, foi parar nas mãos do novo governo que transformou muitos palácios em museus, abriu vários jardins de nobres à visitação pública, ampliando o acesso da população àquilo que antes era exclusivo de um grupo específico. Os museus nacionais se tornaram espaços “destinados a colocar disponíveis o equivalente das coleções privadas dos príncipes" ${ }^{\text {68 }}$. Ou seja, após um período de tentativa de tornar coerente o discurso da ruptura com ações de ruptura (mudança do calendário, destruição de

\footnotetext{
${ }^{67}$ QUICHERAT, J. Aperçus nouveaux sur l'histoire de Jeanne d'Arc. Paris: Jules Renouard, 1850. 1850. p. 165. Tradução nossa.

${ }^{68}$ THIESSE, A. M. La création des identités nationales. Editions du Seuil, 2001. p. 145. Tradução nossa.
} 
monumentos e documentos), o governo passa a ressignificar toda essa herança do passado em uma atitude conservadora.

Em relação à Joana d'Arc, não podemos dizer que foi esquecida para ser relembrada após a Revolução Francesa pelos historiadores do século XIX. Como afirmam Bouzy e Vercruysse, sua epopeia sempre esteve presente na produção de livros do Antigo Regime. Em relação às fontes vemos em L'Averdy uma preocupação em torná-las a principal base de informações sobre Joana, mas em relação à documentação, aos processos, o reconhecimento vai para o século XIX uma vez que Joana e suas fontes serão ressignificadas tendo em vista os novos padrões advindos do discurso de ruptura revolucionária.

O fato de ter sido escrito, em 1795, do outro lado da Mancha o poema Joana of Arc, an epic poem por um republicano e francófilo poderia fortalecer o argumento de que o momento da Revolução fora propício para a associação dos ideais de Joana e da liberdade defendida pelos revolucionários. Robert Southey diz que no momento da coroação de Charles VII em Reims, Joana havia profetizado a Declaração dos Direitos do Homem e do Cidadão. No entanto, o olhar estrangeiro, em especial o inglês, para quem até então o significado da palavra revolução representava mais um retorno à origem de um momento fundamental de liberdade do que uma ruptura com o passado ${ }^{69}$ deve ser relativizado. No contexto francês vemos que o desejo de romper com o passado trouxe inúmeros questionamentos sobre a figura de Joana d'Arc que teve que passar por um processo de ressignificação que a definiu como heroína nacional.

69 Cf. verbete "Revolução" em: WILlIAMS, R. Palavras-Chave. Um Vocabulário de Cultura e Sociedade. São Paulo: Boitempo Editorial, 2007. Cf. também: GARCIA, P. op. cit. Esse autor lembra que até então o termo revolução tinha conotação astronômica, transmitindo uma ideia de retorno e não de ruptura. Nesse sentido, as revoluções inglesa e americana são lidas na chave de retorno a uma condição inicial de liberdade para se restaurar os direitos adquiridos em um momento primordial. 
Retomando a afirmativa de Lightbody, vemos que a Revolução Francesa só foi um evento decisivo para a reputação de Joana d'Arc porque desenvolveu um ambiente tão ambíguo e contraditório em relação a ela que a posteridade buscou ressignificá-la de forma definitiva, relacionando-a aos ideais eternizados pelos liberais do século XIX que tiveram à sua disposição os mecanismos do nascente nacionalismo, a partir do qual a imagem da Donzela pôde ser reestruturada. Joana foi ressignificada no contexto da “criação do nacional” fenômeno que não era exclusivo da França ${ }^{70}$. Os conflitos de sua ressignificação têm que ser analisados tendo em vista esse período caracterizado pela escolha dos ancestrais, a criação do patrimônio, a coleta do chamado "material folclórico", e o surgimento das histórias nacionais com seus heróis e momentos fundadores numa nacionalização retroativa dos eventos do passado.

Nesse mesmo ambiente em que temos a retomada da Idade Média, os historiadores vão reivindicar a posição da história como ciência. A ideia de ruptura revolucionária interfere também de forma definitiva na compreensão do surgimento dessa ideia.

"O princípio de descontinuidade introduzido no cisma revolucionário seria expresso sobre um modo poético, na falta de outros meios antes que o recuso sistemático de ida às fontes e a crítica aos documentos viesse fundar uma real matiz cognitiva da distância do passado."71

Para Gauchet, o Romantismo foi a única expressão possível da ruptura de 89 até surgir a história-ciência, o que só teria acontecido após a Revolução de 1830. Trata-se ainda da visão da "cisão de 89" como patrocinadora do surgimento da História, a

\footnotetext{
${ }^{70}$ Note-se que nesse momento o estilo gótico torna-se a arquitetura nacional de vários países.

${ }^{71}$ GAUCHET, M. "Les Lettres sur l'histoire de France d'Augustin Thierry. L'alliance austère du patriotism et de la science". In: NORA, P. Op. Cit.. p. 787-850. p. 791. Tradução nossa.
} 
mesma visão de ruptura, como se antes não houvesse a ida às fontes e a crítica documental que no caso de Joana d'Arc deve ser relativizado, como vimos em relação aos trabalhos de L'Averdy.

A partir da valorização da História e da criação de órgãos de memória, pesquisa e preservação, os historiadores tomam como sua responsabilidade estabelecer a verdade sobre o passado nacional considerando-se originais em vários pontos. Na historiografia joânica não foi diferente. Exaltando seu amor incondicional pela verdade, vinda da crítica às fontes, Quicherat anuncia que desejava narrar a história de Joana d'Arc sem misticismo ou ocultismo ${ }^{72}$. O amparo racional-científico para o processo de construção da identidade nacional a partir de uma ressignificação do passado se configurou no desenvolvimento do método histórico.

Garcia afirma que a tarefa primordial da História era conceber um discurso que explicasse a ruptura revolucionária e que pudesse articular as partes desagregadas da história da França. Entre 1815 e 1830, em especial, o desafio era a legitimidade das elites burguesas na sua participação do governo francês e a validade do compromisso constitucional iniciado pela Carta de 1815. Nossa hipótese é que isso vai ser feito através de uma valorização do passado a partir de elementos de ressignificação. Havia uma fragilidade dos governos e das instituições políticas no que se refere à participação da burguesia nos novos quadros governamentais da Restauração. Dessa forma, passa a existir a necessidade de se produzir um discurso poderoso e convincente. O historiador assume essa tarefa como um profeta que tinha como missão dizer a verdade sobre a história da França.

${ }^{72}$ QUICHERAT, J. "Prefácio". In: Aperçus nouveaux sur l'histoire de Jeanne d'Arc. Paris: Jules Renouard, 1850. 
Após a revolução de 1830 a imagem produzida acerca da Idade Média ainda não deixa de se relacionar aos temores da burguesia francesa, como percebe Christian Amalvi:

\begin{abstract}
"A geração culta de 1830 descreve a Idade Média como uma esplêndida catedral gótica cercada por uma inquietante "Corte dos milagres" cheia de mendigos e envolta pela fumaça de sinistras fogueiras acesas por inquisidores fanáticos. Essas duas imagens fortes traduzem duas obsessões da burguesia liberal do século XIX: as ameaças que a ordem social sofria (em relação a seus privilégios) pelas classes trabalhadoras julgadas a priori perigosas (Louis Chevalier) e, em outro domínio, o perigo clerical e ultra-montano contestando os fundamentos laicos e racionalistas de uma sociedade secularizada e que sonha com um retorno inquietante à Cristandade medieval. "73
\end{abstract}

Sem dúvida, todos esses fatores explicam as novas atribuições recebidas por Joana d'Arc nesse período. Tentando explicar o fato do século XIX ser considerado o "século de Joana", Winock identifica quatro processos que favoreceram esse fenômeno: o movimento romântico com seu gosto pelas aparições históricas relacionadas à alma do povo; o avanço do patriotismo; a renovação do catolicismo após Napoleão e o surgimento de um conhecimento histórico que privilegia as fontes. Vemos, no entanto, a necessidade de se inserir todos esses processos em um ambiente mais amplo, o de uma ressignificação do passado.

A ideia de ressignificação impedirá que incorramos em certas análises, já cristalizadas na historiografia joânica, que tendem a separar os autores como pertencentes a diferentes tradições historiográficas e acabam criando grupos definidos, tanto pela proximidade cronológica quanto pela afinidade político-partidária. Sem ignorar a influência desses fatores, a análise buscará ver os autores da primeira metade

${ }^{73}$ AMALVI, op. cit. p. 261. 
do século XIX além das definições clássicas de restauradores, monarquistas, republicanos ou liberais. Objetiva-se captar a formação de uma certa tradição historiográfica que se pautará principalmente pela ideia de ressignificação e conservação. A divisão entre historiadores liberais versus monarquistas empobreceria o debate em relação às fontes. A tese de Krumeich, por exemplo, vai na direção de uma polarização de historiadores liberais e republicanos em oposição aos católicos monarquistas que poderia ser identificada de forma embrionária desde o início do século XIX e que teria se acentuado ao longo desse século. Dessa forma, ele identifica no trabalho dos historiadores monarquistas estereótipos vindos do Antigo Regime e segundo suas próprias palavras seria necessária uma "revolução copernicana" para que houvesse outra visão. Essa ideia nos impede de verificar uma tradição mais ampla no que se refere à construção de uma nova imagem para Joana d'Arc no século XIX, pois não permite a percepção de que muitas vezes os autores liberais usaram temas desenvolvidos pelos monarquistas - embora não assumidamente -, fato que só podemos compreender quando nos damos conta de que foi o próprio discurso dos liberais que criou essa divisão pela qual eles buscavam se mostrar originais e desqualificar o trabalho dos monarquistas. A ideia de ressignificação nos poupará ainda do que poderia nos levar a encarar a questão da importância das fontes para a história de Joana d'Arc como obra da história-ciência do século XIX e não como a ressignificação de um processo iniciado em um período anterior.

Além do mais, o poema Joan of Arc escrito pelo republicano Southey durante o próprio curso da Revolução, como vimos, nos ajuda mais uma vez a questionar essa estrutura rígida segundo a qual podemos identificar apenas no século XIX, e após o período da Restauração, um interesse dos republicanos por Joana d'Arc. 
O processo de ressignificação encontra seu ambiente fértil e necessário na primeira metade do século XIX. A nosso ver, tudo o que marca o "fenômeno Joana d'Arc" posteriormente se relaciona a esse momento crucial. Esse marco cronológico orientará, portanto, nossa investigação uma vez que o entendemos como de suma importância para a popularização e para as novas atribuições recebidas por Joana d'Arc na segunda metade do século XIX e no século XX.

Para chergarmos ao ponto central do processo de ressignificação será necessário atentarmos para o problema do gênero narrativo que orientou a composição das obras que tratam de Joana d'Arc. Por meio do estilo próprio tanto às histórias nacionais quanto às biografias, os autores conseguirão relacionar a epopeia de Joana d'Arc a discussões muito pertinentes do período pós-revolucionário, em especial, aos debates sobre como ultrapassar a individualidade em prol do benefício coletivo e como mobilizar o poder revolucionário das massas. 


\section{CAPÍTULO II - Entre a biografia e a História Nacional, a epopeia de Joana d'Arc}

As obras que tratam de Joana d'Arc na primeira metade do século XIX nem sempre falam exclusivamente de sua história. Muitas vezes os autores dedicavam um momento dentro de narrativas mais abrangentes para explicar o advento da Donzela e falar sobre suas realizações. No entanto, não há como ignorar o aspecto biográfico que as obras assumem no momento em que Joana aparece no cenário nacional. De fato, os autores sentiram a necessidade de expor a trajetória de vida da Donzela valendo-se, muitas vezes, de tópicas próprias ao gênero biográfico. Mas esses escritores não irão separar as ações de Joana, por mais particulares que pareçam, de seu efeito geral. Veremos que parte da ressignificação pela qual passa a imagem de Joana d'Arc no século XIX se relaciona a essa tensão particular versus geral, advinda da associação de características das biografias com as das histórias nacionais, sendo tal tensão um dos elementos que sedimentaram sua imagem de heroína nacional.

\section{1 - Da necessidade da história da França na vida de Joana d'Arc}

Em Jeanne d'Arc ou coup d'oeil sur les révolutions en France au temps de Charles VII et surtout de La Pucelle d'Orléans, escrito por Berriat Saint-Prix e publicado em 1817, encontramos uma estrutura já recorrente em narrativas sobre Joana d'Arc anteriores ao século XIX, na qual para introduzir sua história o autor volta ao final do século XIV momento em que localiza um período favorável para a França sob o governo de Carlos V.

O próprio autor explica essa necessidade: 
"O título precedente mostra o objetivo que se propõe ao compor esse ensaio histórico e o sistema segundo o qual se redigiram as notas. Sem negligenciar os eventos anteriores a Carlos VII, limitou-se a indicar ou constatar aqueles de seu reino que têm relação com a revolução ocorrida no tempo de Joana d'Arc." 74

Para entender o significado do advento da Donzela esses autores precisam explicar o contexto de sua aparição, esclarecendo que ao reinado justo e equilibrado de Carlos V sucede o desastroso momento do governo de Carlos VI que, frequentemente afetado por suas crises de loucura, tinha que se afastar do trono francês deixando-o sob o cuidado dos regentes, seus tios. Nesse ponto é localizada a semente da crise gerada na nobreza francesa que levou ao assassinato do duque de Orléans por João sem Medo em 1407 e, dessa forma, à formação de grupos antagônicos na nobreza francesa ligada à família real: a famosa disputa entre borguinhões e armagnacs. A aproximação do ramo borguinhão com os ingleses traz novos contornos às disputas da Guerra dos Cem Anos e torna extremamente complicada a sucessão de Carlos VI. Após sua morte, o Delfim não pode assumir o trono devido às determinações do Tratado de Troyes, assinado em 1420 e muito influenciado pela vitória inglesa na batalha de Azincourt, que definia como herdeiro para o trono da França o rei da Inglaterra e passava para ele o direito sobre vários territórios franceses. De acordo com Saint-Prix após a morte de Carlos V "maus ventos invadem a França." ${ }^{75}$ É um momento em que muitos autores monarquistas, como Berriat Saint-Prix, aproveitam para criticar a ideia de regência e os males consequentes de uma administração provisória e dividida entre várias pessoas que se movem a partir de interesses pessoais. A ideia que se sustenta é a de que o reino vai bem enquanto o rei legítimo está guiando seu povo. Os regentes trazem problemas e

\footnotetext{
${ }^{74}$ SAINT-PRIX, Berriat. Jeanne d'Arc ou coup d'oeil sur les révolutions en France au temps de Charles VII et surtourt de La Pucelle d'Orléans. Paris: Chez Pillet, 1817, p. 97. Tradução nossa.

${ }^{75}$ SAINT-PRIX, B. op. cit. p. 10. Tradução nossa.
} 
naquele fim de século XIV suas extravagâncias levaram à extorsão do povo. Carlos VI teria deixado o reino aos predadores, ministros e cortesãos sem aplicação, cheios de caprichos e fantasias. Nesse momento, o autor compara Isabel da Baviera à Fredegonda e Carlos VI aos merovíngios. Dessa forma, vai traçando todas as intrigas da nobreza e Casa Real francesas que culminaram no assassinato de João sem Medo em 1417 e o massacre sofrido pelos armagnacs em 1418, aproveitando para nesse momento isentar o Delfim, futuro Carlos VII da culpa pela morte de João sem Medo.

Para explicar o contínuo caos do reino que se manteve após esses acontecimentos, Saint-Prix fala da personalidade de Carlos VII que preferia se ocupar de festas, deixando as províncias às pilhagens de seus ministros, dizendo que ironicamente "É esse o príncipe ao qual os historiadores deram o epíteto de Vitorioso. Se ele triunfa é graças ao desenvolvimento de seus guerreiros e de seus povos e a eventos fortuitos e jamais a seus trabalhos ou a seus esforços." ${ }^{, 76}$

Antes de escrever sobre o aparecimento de Joana propriamente dito, o autor trata de dar tons sombrios à sua interpretação do momento político e social que a França vivia em 1428: "Chegamos enfim a um ponto em que a França parecia sucumbir. Ela tinha, com efeito, um inimigo formidável, e estava praticamente desprovida de meios de defesa."77

Após traçar essa situação de caos o autor se pergunta como a situação havia chegado àquele ponto se na época da morte de Carlos $\mathrm{V}$ havia um momento de relativa paz e prosperidade. Segundo ele deixar essa questão sem reposta seria “(...) autorizar a pensar que a libertação da pátria, cuja narrativa é, sobretudo o objeto dessa obra, foi um

\footnotetext{
${ }^{76}$ Idem, p. 36.

${ }^{77}$ Idem, p. 45.
} 
evento muito pouco extraordinário para merecer qualquer atenção." ${ }^{, 78}$ Sem dúvida SaintPrix busca um efeito de contraste entre esses tempos sombrios e o advento de Joana d'Arc como estratégia para enaltecer seu objeto de estudo, o que está presente de forma insistente na historiografia joânica. Quanto mais se entende o momento desesperador pelo qual a França passava, mais se compreende o alcance das ações de Joana. Trata-se de reforçar a argumentação de que o momento da aparição da Donzela significou uma revolução naquele momento da história da França.

Le Brun des Charmettes tem uma estratégia parecida para introduzir a história de Joana d'Arc. Em sua Histoire de Jeanne d'Arc, surnommée la Pucelle d'Orléans, tirée de ses propres déclarations, de cent quarante-quatre dépositions de témoins oculaires, et des manuscrits de la Bibliothèque du roi et de la Tour de Londres, de 1819, ele reforça a ideia de desolação que a França vivia naquele período da Guerra dos Cem Anos. Porém, segundo seu método, para entender a história de Joana d'Arc deve-se voltar à origem do conflito no qual ela apareceu: as guerras entre Pepino e os saxões:

“(...) Lendo as páginas sangrentas em que a história traçou a narrativa dessas guerras, pode-se reconhecer nos franceses e nos saxões do século VII os franceses e os ingleses do século XIV: a mesma antipatia, a mesma fúria, o mesmo heroísmo em meio à barbárie, animando essas duas grandes raças em combates separados por um intervalo de sete séculos." ${ }^{, 7}$

A epopeia de Joana é inscrita por ele em um conflito de longa duração, como se os humores, oposições e animosidades de outrora acompanhassem aqueles povos de forma quase atemporal. Um artifício para engrandecer o advento da Donzela que teria vindo para promover a resolução de um conflito centenário.

\footnotetext{
${ }^{78}$ Idem, p. 46.

${ }^{79}$ DES CHARMETTES, Lebrun. Histoire de Jeanne d'Arc, surnommée la Pucelle d'Orléans, tirée de ses propres déclarations, de cent quarante-quatre dépositions de témoins oculaires, et des manuscrits de la Bibliothèque du roi et de la Tour de Londres, 4 vol., 1817. p. VII. Tradução nossa. op. cit. p. 6.
} 
Assim como Saint-Prix, Charmettes caracteriza a regência dos tios de Carlos VI como um momento de tirania, insinuando que a primeira crise de loucura dele foi ocasionada por uma armação de seus tios. A partir dessa crise Carlos VI "entra num estado de estupor e distração mais deplorável que a morte." 80

Em meio às considerações gerais, elementos do gênero biográfico se fazem presentes. No momento em que narra o alinhamento dos borguinhões com os ingleses Saint-Prix aproveita para esclarecer o modo como vê a tarefa do historiador, nesse caso mais específico visto como um biógrafo que julga a memória dos antepassados:

"Chegamos em um momento em que somos tentados a abandonar nossa tarefa, para nos isentarmos de lembrar a infâmia com a qual se cobriam nossos antepassados. O historiador é, isso é certo, tolerante com seus erros, mas também sem piedade e mesmo sem indulgência com seus vícios e crimes. Mais lamentavelmente do que o juiz, ele não é livre como este para recusar a se pronunciar sobre a causa de seus parentes e das pessoas às quais ele tem algum interesse: longe disso, ele é obrigado a fechar seu coração a todos os sentimentos ternos para desonrar sem consideração a todos aqueles que faltaram com a lei da virtude. (...) Ricos, guerreiros, escritores sábios, magistrados, administradores, pontífices, ministros, potentados, todos são desejosos de deixar uma memória honrada e todos sabem que, cedo ou tarde, ela será traduzida e julgada sem apelo por esse tribunal inflexível e sem dúvida o receio da pena vingadora de algum Tácito abafaram os projetos de mais de um jovem Nero. "

Expor as motivações que levaram o autor a escrever sobre determinado personagem é um topos da biografia ${ }^{82}$. Em geral escrever sobre Joana d'Arc assume um aspecto de fazer justiça à sua memória, dar a ela um lugar merecido entre os maiores franceses, um sentimento de que ela nunca foi lembrada como deveria. Essa justiça se

\footnotetext{
${ }^{80}$ Idem, p. 36. Tradução nossa.

${ }^{81}$ SAINT-PRIX,B. op. cit. p. 19-20. Tradução nossa.

${ }^{82}$ DOSSE, F. O desafio biográfico - escrever uma vida. São Paulo: Edusp, 2009.
} 
faz, sobretudo em reação ao polêmico poema de Voltaire no qual o autor usa de muita ironia e sarcasmo para falar de Joana d'Arc.

\begin{abstract}
"Que suas mãos se tranqüilizem, contudo! A voz da justiça aparece cedo ou tarde; e quanto mais ela foi abafada pelo ódio ou pela prevenção, mais ela se faz compreender com esplendor. Já equilibrada apreciadora dos tempos e circunstâncias, ela proclama alto que se Joana pôde se deixar fascinar pela ideia de ter sido enviada pelo Eterno, essa ilusão enobrecida por outro lado pelo civismo que foi sua fonte, foi favorecida pelas opiniões de seus contemporâneos, enquanto que suas virtudes foram as virtudes de todos os séculos. Enquanto o pudor, a piedade, a bravura, a generosidade, a devoção à pátria forem honrados pelos franceses sua lembrança viverá entre eles e eles a apresentarão a seus filhos como um modelo mais fácil a imitar do que a esperar. " 83
\end{abstract}

Le Brun des Charmettes quer também fazer justiça à memória de Joana lamentando-se do espaço ainda tímido que a personagem ocupa no rol dos heróis franceses. Segundo ele se ela tivesse nascido na Grécia ou Itália todas as circunstâncias de sua vida teriam sido recolhidas por grandes escritores como Xenofonte, Plutarco ou Tito-Lívio e a ela teriam sido dedicados monumentos de bronze às margens do Egeu e do Tibre. Ele faz um histórico dos monumentos feitos à Joana d'Arc desde sua época enumerando os vários episódios em que foram destruídos e reconstruídos. O autor lamenta ainda que não exista até aquele momento nenhuma narrativa que traga a história completa, exata e regular de Joana que trate com rigor os documentos:

"Será que não é hora de um francês se levantar? Que procure, reúna, que tire do esquecimento os títulos de glória de uma desafortunada, vítima de sua devoção pela França; que apresente esses títulos à nação muito tempo indiferente ou abusada que a acorde e lhe diga: ' $O$ evento mais extraordinário que jamais figurou nos anais dos povos é, ao mesmo tempo por

${ }^{83}$ SAINT-PRIX, B. op. cit. p. 10. Tradução nossa. 
circunstancia única, aquele que repousa sobre as provas mais numerosas, mais irrefragáveis'?"84

Aí residia a completa originalidade do advento de Joana d'Arc. Em que se funda a convicção sobre os feitos de Pausânias, Aristides e Temístocles contra os persas ou os de Alexandre? Sobre o testemunho dos historiadores que na maior parte das vezes eram de épocas posteriores, que escreveram de acordo com a tradição ou memórias das quais ninguém garante a fidelidade. "Compare agora esse testemunho com os 144 depoimentos recebidos na revisão do processo da Donzela" ${ }^{\natural 5}$. A superioridade de Joana está na possibilidade de se fazer uma história a seu respeito baseada em documentos legítimos. Daí resulta também uma hierarquia entre as fontes. O processo de condenação é superior para narrar a história da Donzela, pois é ela quem fala diante de seus juízes: “(...) é Joana que parece recontar hoje sua própria vida e pleitear ela mesma sua causa diante do tribunal da posteridade." ${ }^{\prime 86}$

Ao insistir no fato de que deixou os documentos falarem por si, de ter deixado as próprias fontes contarem a história, Charmettes indica a superioridade de Joana em relação a todos os heróis. Ela era uma heroína histórica e não literária. Sua epopeia é verdadeira e verificável. Aí encontramos o que, para ele, seria uma biografia histórica. Ele usa elementos do gênero biográfico para justificar sua narrativa - a suposta falta de obras que engrandecem seu personagem - e fortalece tal elemento ao acrescentar a ideia de prova documental.

\footnotetext{
${ }^{84}$ DES CHARMETTES, Lebrun. Histoire de Jeanne d'Arc, surnommée la Pucelle d'Orléans, tirée de ses propres déclarations, de cent quarante-quatre dépositions de témoins oculaires, et des manuscrits de la Bibliothèque du roi et de la Tour de Londres, 4 vol., 1817. P. VII. Tradução nossa.

${ }^{85}$ Idem, p. VIII. Tradução nossa.

${ }^{86}$ Idem, p. X. Tradução nossa.
} 
Para traçar o perfil de Joana d'Arc, Charmettes esclarece que em outras histórias a abundância de detalhes seria ruim, pois causaria fadiga. Mas na história de Joana a ausência de detalhes seria inconveniente ${ }^{87}$, pois poderia levar o leitor à desconfiança e o impossibilitaria de emitir uma opinião. Para se julgar um indivíduo não é suficiente vêlo em sua vida pública; ele deve ser visto fora de cena, na vida privada: "imagina como esse exercício é necessário quando tal indivíduo se anuncia como encarregado de uma missão divina e cujas realizações parecem justificar sua fala?" ${ }^{88}$ Assim, os menores detalhes são importantes, como a aparência, o modo de viver, os gostos, aversões, modos de expressão, sendo que o nível privado poderia explicar por causas naturais fatos que se fossem vistos de forma isolada excitariam mais desconfiança do que admiração.

Tal tendência se insere em uma tradição mais ampla. As biografias desse período estavam muitas vezes influenciadas por estruturas presentes em autores da Antiguidade, com destaque para Plutarco. A trajetória de Vidas Paralelas em que o autor narra as vidas de Teseu, Rômulo, Aristides, Alexandre e César dentre outros, mostra-nos a aceitação e recepção dessa obra pelo público de diferentes períodos. Muito citada na Renascença, momento da exumação do heroísmo à moda antiga, lida por Luís XIV e Rousseau, torna-se um modelo para Napoleão, tendo influência até a Restauração. Em nosso caso vemos a importância do modelo fornecido por Plutarco em muitas ocasiões. Na vida de Alexandre, o autor coloca que:

"De resto, nem sempre são as ações espetaculares que mostram melhor a virtude ou o vício: um fato insignificante, uma palavra, uma pilhéria, às vezes, revelam com mais clareza o caráter que

\footnotetext{
${ }^{87}$ Isso levou Lebrun a escrever sua obra em 4 tomos de aproximadamente 500 páginas cada um!

${ }^{88}$ CAHRMETTES, L. op. cit. p. XIV. Tradução nossa.
} 
combates sangrentos, batalhas acirradas ou assédios portentosos." 89

Françoise Frazier diz que as biografias morais de Plutarco conciliavam o princípio biográfico (emprego de lugares comuns que seguem etapas da vida humana) e o princípio ético (os topoi que correspondem à divisão entre bens do corpo e da alma ${ }^{90}$. A repetição de certos fatos nas biografias que tratam de um mesmo personagem é a correta aplicação de modelos para esse gênero. Plutarco fixara "os ditos, os feitos e os gestos que, aparentemente banais, ofereciam pistas sobre a personalidade." $" 91$

A obra de Plutarco vai se manter como um modelo para o gênero biográfico com a integração entre o perfil físico e moral dos personagens. Além disso, em Plutarco, os heróis tem traços em comum: uma personalidade forte aliada a um ideal ao qual se consagram por completo. Um ponto de interesse era a tensão entre a virtude e o trágico, sobre como um humano se sujeita à prova da ação.

A necessidade de narrar os detalhes do biografado que percebemos em Lebrun des Charmettes se parece com a estrutura difundida pelas obras de Plutarco a partir das Vidas paralelas. Além disso, é notório em Charmettes o impacto homero-virgiliano, também visível em Aurelia ou Orléans delivrée ${ }^{92}$ de Jean Roussy, de 1738, uma vez que Charmettes tem em mente os épicos clássicos: sobre o cerco de Montargis ele afirma: “(...) a descrição corresponde exatamente àquela que fez Homero dos barcos gregos diante de Troia." 93

\footnotetext{
${ }^{89}$ PLUTARCO. "Vie d'Alexandre". In: Vies Paralèles. I. Garnier-Flamarion, 1995. P. 9. Tradução nossa.

${ }^{90}$ FRAZIER, F. Histoire et morale dans le 'Vies Paralèles' de Plutarque. Paris: Les Belles Lettres, 1996.

${ }^{91}$ Idem, p. 45. Tradução nossa.

${ }^{92}$ Poema dedicado ao Cerco de Orléans.

${ }^{93}$ CHARMETTES, op. cit. p. 97. Tradução nossa.
} 
Ao destacar as qualidades da família de Joana, Charmettes apresenta características típicas ligadas ao heroísmo: piedade, simplicidade, honestidade, castidade em sua linguagem. Para confirmar essas características usa as notas dos processo de condenação e de anulação da condenação. Ele compara a casa onde Joana nasceu com a casa de Filêmon e Baucis, camponeses pobres (personagens de Ovídio) que recebem em sua casa os deuses Júpiter e Mercúrio. Casa hospitaleira, humilde e casta "onde todas as virtudes habitavam, segundo a fábula."94

Assim como o casal pobre que, por suas virtudes, foi digno de receber os deuses, os pais de Joana puderem recebê-la. Aqui a condição de humilde é exaltada não do ponto de vista social, mas moral. Não se deve imaginar que exista uma associação entre Joana d'Arc e o povo nesse sentido. A pobreza de Joana não é um dado econômico, mas um ingrediente a mais que revela o caráter heroico de sua personalidade que não conheceu barreiras. Assim entende-se a singularidade de Joana do ponto de vista de Charmettes: sua história contém todos os elementos das fábulas, mas tudo era verdadeiro no sentido de que há uma materialidade a ser comprovada, sua casa ainda está lá, em Domrémy! A casa humilde da qual Ovídio fala existe objetivamente, não está no plano divino, mas no humano. Esse argumento embasa sua ideia de que o governo deveria fazer de tudo para preservar aquela casa como um patrimônio nacional. "Nesse sapê rústico nasceu a libertadora da França, a heroína do século XV."95

"boa moça, simples, casta, modesta, moderada, paciente, prudente, muito doce, trabalhadora, temente a Deus, gostava de fazer caridade e servir aos doentes. (...) Tinha bons modos, uma fala honesta, nunca jurava, obedecia aos pais e procurava a companhia das mulheres e moças mais virtuosas. Cedia seu

\footnotetext{
${ }^{94}$ CHARMETTES, op. cit. p. 243. Tradução nossa.

95 Idem, p. 245. Tradução nossa.
} 
próprio leito, tinha pouco gosto pelo canto e pela dança, era tímida." $" 96$

Todos os adjetivos vêm acompanhados de notas que especificam no processo de anulação qual testemunha atribuiu essa qualidade à Joana. Nesse trecho vemos a influência da tradição filosófica da antiguidade que atribui quatro virtudes cardeais aos herois ${ }^{97}$. A justiça seria a virtude suprema que coordena o funcionamento das três partes da alma, cada qual com sua virtude correspondente: a parte racional cuja virtude é a prudência; a parte irascível, cuja virtude á a coragem; e a parte concupiscível cuja virtude é a abstinência. Joana d'Arc era a heroína perfeita para França porque tinha todos os elementos dos heróis pagãos, mas era cristã. Como Charmettes era católico, defendia com base na documentação o reconhecimento dela como tal.

Charmettes sente também a necessidade de dar descrições físicas de Joana. Aqui nota-se seu desejo de colocar sua obra como pertencente a uma tradição clássica de louvor aos heróis ou, no mínimo, evocar uma vida que poderia ter sido escrita por Plutarco, uma vez que sua obra parece ter sido influenciada por ele em vários momentos. A partir dos depoimentos do processo de anulação, ele tenta traçar as características físicas de Joana, que sendo aparentemente frívolas, explicam a facilidade que Joana teve para convencer os personagens do reino a ouvirem uma simples pastora. Por várias razões ele imagina que ela era alta, forte, de membros proporcionais, bela e bem formada, de cabelos claros, olhos grandes entre o verde e o marrom, melancólicos e doces, de boca pequena, com mãos bem feitas, dedos longos e afilados, a voz doce. "A candura, a inocência virginal, a pureza angelical, com alguma coisa de sonhadora e uma

\footnotetext{
${ }^{96}$ Idem, p. 253. Tradução nossa.

${ }^{97}$ FRAZIER, F. op. cit.
} 
ponta de tristeza formavam a característica geral de sua fisionomia."98 São características físicas que em verdade refletem seu perfil moral, fonte de explicação do sucesso de seus empreendimentos.

A questão do heroísmo feminino se coloca no momento em que descreve suas características físicas. Para se adequar ainda mais a seu modelo de herói, Charmettes atribui uma característica peculiar à Donzela em relação às outras mulheres:

"Enfim, uma particularidade muito notável parecia manifestar os desejos de Deus em relação a ela. Mulher pela doçura, o pudor e a modéstia, mas isenta da maior parte das fraquezas associadas ao seu sexo, ela também não estava sujeita a esse tributo regular e incômodo que, mais do que as leis e os costumes, interdita em geral às mulheres as funções as quais são atribuídas aos homens." 99

Embora não seja um argumento novo ${ }^{100}$ - o fato de Joana estar isenta do ciclo menstrual - ele usa um atributo do âmbito privado para explicar suas ações públicas, no caso a perfeição com que assumia os diversos papéis. De fato, não será apenas nesse autor que as atribuições individuais da Donzela são evocadas para explicar as circunstâncias e resultados impressionantes de suas ações, como veremos mais adiante. No caso da história de Joana d'Arc a presença de estruturas do gênero biográfico servirá também ao propósito daqueles que a encontraram a partir da História da França.

\section{2 - Da necessidade da vida de Joana d'Arc na história da França}

Sismonde de Sismondi, suíço membro de várias sociedades eruditas europeias como a Academia Imperial de São Petersburgo, Academia Real de Ciências da Prússia e correspondente do Instituto da França, se ocupou em escrever uma História dos

\footnotetext{
${ }^{98}$ CHARMETTES, L. op. cit. p. 369. Tradução nossa.

${ }^{99}$ CHARMETTES, L. op. cit. p. 320. Tradução nossa.

${ }^{100}$ Essa ideia aparece desde a Chronique de la Pucelle do século XV.
} 
Franceses desde os capetíngios. São 31 volumes publicados entre 1821 e 1844 e Joana d'Arc aparece no $13^{\circ}$ volume dessa obra, mais especificamente no capítulo III. Saindo de uma narrativa meramente biográfica por não apresentar sistematicamente os acontecimentos da vida de Joana desde seu nascimento, Sismondi dá uma interpretação mais geral em que relaciona a vida da Donzela não só ao contexto da Guerra dos Cem Anos, como também ao momento mais geral vivido pelos homens europeus, ainda que afirme no fim do capítulo II que Joana d'Arc mudou a sorte da França naquele momento.

"Um sentimento religioso de penitência, de amor e de esperança cobria todos os corações; era necessária apenas uma centelha para produzir uma explosão. Uma jovem camponesa de Domrémy nas fronteiras da Lorraine, Joana d'Arc, a Donzela de Orléans, acendeu essa centelha e a sorte dos franceses mudou. $" 101$

Para introduzir a história de Joana d'Arc, Sismondi volta ao contexto geral que envolvia toda a Europa: a ocorrência de um "Movimento literário e religioso dos espíritos". Dessa forma, ele vai elencando características da Renascença e enaltecendo o fato dos eruditos italianos estarem, naquele momento, tentando resgatar a civilização através da retomada dos textos latinos e gregos. O autor admira-se também do fato de que na Alemanha se produzia um movimento análogo nos espíritos, referindo-se ao conflito da Igreja Católica com os hussitas como uma prefiguração da Reforma Luterana. Sismondi busca encaixar todos os países europeus nesse mesmo "movimento". "Assim acontecia com lentidão, mas com uma marcha invariável, o progresso das luzes e a lenta reforma nos espíritos: a escravidão das consciências não era mais a mesma." 102

\footnotetext{
${ }^{101}$ SISMONDI, S. Histoire des Français. Paris. T. 13, p. 102.

${ }^{102}$ Idem, p. 108. Tradução nossa.
} 
Mas como se tratava de um período de transição, da era supersticiosa do medievo às luzes trazidas pelo movimento renascentista, ainda era possível perceber crenças, superstições e a falsa ideia de que tudo era obra da Providência. Os filósofos do período nada faziam para acabar com aquelas crenças. O povo estava mergulhado na superstição e na ignorância e isso era culpa dos próprios padres e sábios que deveriam instruí-lo, mas não o faziam.

O sofrimento do povo francês aumentava sua devoção e esse era um solo fértil para as crenças. Joana acaba sendo fruto desse meio supersticioso influenciado pelo desejo de expulsar o inimigo nas regiões dominadas pelos ingleses em que se espalhava um entusiasmo político e religioso. Em relação à vida privada de Joana - seu nascimento, infância, ambiente familiar - ele não oferece muitos detalhes, preferindo colocar sua aparição como fruto de um ambiente político, religioso e social mais amplo. Sismondi encontra Joana a partir da história francesa, e é esta quem dita o aparecimento da Donzela ao longo da narrativa, fato que explica a ausência do percurso de uma vida em destaque. Esse fato, no entanto, não significa que características específicas de Joana não tenham definido o fato de ela ser a condutora do processo de libertação da França, questão que discutiremos mais à frente. O que queremos ressaltar nesse ponto é que os autores que se lançavam à história da França no período da Guerra dos Cem Anos precisaram encontrar um lugar e uma forma de abordar o advento da Donzela, aliando-o aos acontecimentos gerais. A peculiaridade de Sismondi se dá na medida em que ele pretende analisar um contexto que ultrapassa a França, "a lenta reforma nos espíritos", para explicar o fenômeno específico representado pela aparição e aceitação de Joana d'Arc. 
Nessa mesma linha interpretativa, ao longo da década de 20 do século XIX, vários autores irão se preocupar em encontrar o nascimento da modernidade francesa. Guizot, em uma das aulas do seu Curso de História Moderna de 1828, conclui que o século XIV foi responsável por fazer a Europa entrar em vias de centralização ${ }^{103}$. A Guerra dos Cem Anos, que ele denominou "Guerras Nacionais da França”, seria a causa desse fenômeno e Joana d'Arc aparece em sua análise como um exemplo de que o evento fora popular, tendo unido a todos no repúdio à ocupação estrangeira.

Antes de apresentar a participação de Joana nas "Guerras Nacionais", Guizot previne o leitor de que nesse período o homem realiza uma obra que só entenderá mais tarde. No destino de um indivíduo define-se o futuro de todo um povo. Guizot considerava que a "parte morta da vida" era a esfera privada, enquanto a "parte viva" era a esfera coletiva. De acordo com ele alguns indivíduos parecem representar o espírito geral de seu tempo, mas esses homens só são grandes por encarnar a singularidade das civilizações. Isso explica o fato de Guizot não ter se dedicado a biografias e é por esse motivo que Joana d'Arc aparece em suas aulas sobre história da França apenas como sintoma geral de um momento.

Segundo Guizot, com a epopeia de Joana ocorre a formação da nacionalidade francesa. Esse fato, porém, não deixa de revelar em sua origem uma diferença entre os grupos sociais, um conflito entre eles. Tal conflito se expressa na atitude de cada grupo em relação à Joana, os pobres amavam-na tão logo a viam, reconheciam seus hábitos piedosos, sua conduta incorrupta. Os nobres tinham desconfianças, queriam provas de sua virtude a todo momento, temiam uma ação diabólica por trás de suas belas palavras.

\footnotetext{
${ }^{103}$ GUIZOT, François. Cours de Histoire Moderne. Paris: Pichon et Didier, 1828.
} 
"Ela foi vista com desconfiança, com ironia, com inimizade pelas pessoas da corte, pelos chefes do exército; ela tinha constantemente por ela os soldados, o povo" 104

Essa suposta discordância de opiniões de diferentes grupos franceses em relação à Joana d'Arc muitas vezes serviu como prova de que ela era uma legítima representante do Terceiro Estado cujo potencial revolucionário já se expressava na Guerra dos Cem Anos. A nobreza, percebendo esse perigo, se colocou contra ela ocasionando seu martírio em Rouen. Essa ideia de divisão e fragmentação por ocasião do avento de Joana d'Arc na história da França encontrou seu maior crítico em Michelet.

Entre os anos de 1833 e 1844 Michelet publica a primeira série de volumes da sua Histoire de France. No capítulo V do tomo X publicado em 1841 de título "Carlos VII - a Donzela de Orléans", Joana d'Arc aparece na história da pátria francesa, como alguém que foi capaz de redefinir rumos, tendo responsabilidade incomparável naquilo que a França viria a ser depois. Deve-se ressaltar aqui o papel proeminente que Michelet dedica à Joana, a quem ele vê não só como aquela que salvou a França das mãos inglesas, mas como a mártir supliciada em nome da liberdade: "Lembremo-nos sempre franceses, que a nossa Pátria nasceu do coração de uma mulher, de sua ternura e de suas lágrimas, do sangue que ela derramou por nós". ${ }^{105} \mathrm{E}$ ao longo dessa obra o autor tenta apresentar tudo o que comprova sua opinião: sem Joana d'Arc não haveria a Pátria francesa, foi necessário que uma virgem sofresse para que mais tarde todos pudessem desfrutar dos benefícios de pertencer à grande França.

\footnotetext{
${ }^{104}$ GUIZOT, F. Cours de Histoire Moderne. Paris: Pichon et Didier, 1828. Tradução nossa.

105 MICHELET, J. Jeanne d'Arc. Avec une introd. et un répertoire explicatif des notes de Michelet par Émile Bourgeois. Paris : Librairie Hachette, 1945. p. 8.
} 
Para enfatizar o advento de Joana d'Arc, ele também usa da estratégia de dar uma interpretação extremamente trágica aos eventos que antecederam a sua aparição gloriosa: "Tudo isso será melhor compreendido se descermos do ponto elevado em que sua lenda se situa, se observamos por um momento a sombria e tenebrosa época, o mundo de profundo lodo de onde surgiu a extraordinária aparição." 106

Sua História da França - escrita em 40 anos - é, na verdade, uma biografia da nação francesa, pois Michelet viu a França como uma pessoa, uma totalidade orgânica que não pode ser dividida. Seu objetivo ao falar de Joana d'Arc era fundir a história da Donzela à da França seu sentido último e verdadeiro. Sobre o volume de sua História da França dedicado a Joana d'Arc e Carlos VII ele diz:

"Espero, nesse volume que vai sair, ter decididamente despojado a minha primeira forma, dominando os pequenos detalhes, de modo a não aparecerem senão subordinados a uma geral harmonia. Vale dizer que creio haver encontrado, por concentração e reverberação, uma chama assaz intensa para fundir todas as nossas diversidades aparentes, para lhes dar na história a unidade que tiveram na vida."107

Michelet não escreveu propriamente biografias, mas o fato de sua tese de doutorado ter sido sobre Plutarco e As vidas paralelas o levou a discutir o lugar do heroísmo no decurso da história. Ele não abandona o papel dos indivíduos e dos percursos biográficos em sua História de França: como vimos, foi em um de seus tomos que ele escreveu sobre Joana. Mas os personagens de destaque entram na história como a encarnação do espírito geral:

"A esse respeito, o herói dos heróis de sua história é, sem contestação, Joana d'Arc. Além de encarnar o povo por sua

\footnotetext{
${ }^{106}$ Idem. p. 29.

${ }^{107}$ MICHELET, J. Lettres inédites. (1841-1871) Paul Sirvein, 1924. APUD FEBVRE, L. Michelet e a Renascença. São Paulo, 1995.
} 
origem, ela faz parte dos oprimidos na qualidade de mulher. $\mathrm{O}$ herói, segundo Michelet, não é um gigante entre anões, como bem mostra a lição de Joana: 'Ele a partir daí vê no herói uma criatura simples entre as criaturas simples, uma criança entre as crianças'. O grande homem de Michelet é, pois, essa mulher figura ideal de um gesto heróico mantido ao longo de um calvário que inclui certo número de lugares, desde a revelação das vozes que lhe falam na floresta até a paixão sofrida em Rouen. Símbolo do povo por ser camponesa inculta, símbolo de pureza por ser virgem, símbolo patriótico por ser mártir: o relato da vida de Joana vale por sua capacidade de encarnar a nação, eterna para Michelet, e não por resgatar um determinado percurso."108

A massa, porém, é quem realiza tudo, os grandes homens fazem muito pouco. $\mathrm{O}$ que os grandes fazem, o conseguem por estarem sobre os ombros do povo. No caso de Lebrun des Charmettes vemos que o fato de Joana ser camponesa, ter nascido em uma casa humilde reforça sua imagem heroica. Nesse caso ele exalta sua simplicidade como um topos recorrente em relação a heróis, pessoas que se destacam em meio à adversidade, o que revela um atributo moral. Mas em Michelet o fato de Joana ser camponesa transforma-se em um dado social uma vez que nesse momento ela se torna a representante, e mesmo a encarnação, do povo. Joana d'Arc é importante para Michelet porque depois da Guerra dos Cem Anos a França caminha para a unidade nacional. A partir disso ela é a representante do povo que coloca o legítimo rei no poder. O povo é a unidade francesa, não uma classe subalterna. A aparição de Joana representa uma França que escolhe seu próprio destino, é a França desejando ser a própria França.

Essa ideia de Michelet se estende à sua interpretação sobre a Revolução Francesa, que para ele é uma encarnação do espírito: todos estão lá, a revolução não pode ser subdividida. O povo é o herói da Revolução, é sua unidade. É por isso que Michelet consegue ver um paralelo entre a Revolução Francesa e o advento de Joana

${ }^{108}$ DOSSE, F. O desafio biográfico - escrever uma vida. São Paulo: Edusp, 2009. p. 178. 
d'Arc. Trata-se da unidade perfeita: antes de Joana, a França não era nada além de uma reunião de províncias, um vasto caos de feudos, um grande país de ideia vaga. "Mas desde o dia do martírio de Joana, pela força do coração, a França se transformou em Pátria. A história de Joana mostra como o amor imenso e puro de um jovem coração abraça todo o mundo, lhe dá esta segunda vida, a verdadeira vida que só o amor dá”. ${ }^{109}$

Portanto vemos que em Michelet há um novo significado da relação particular e geral expresso na sua forma de apresentar uma biografia de Joana d'Arc. É por isso que ele acreditava que só a Revolução Francesa poderia dar a noção exata de quem era Joana d'Arc, pois foi a primeira vez em que se sentiu o poder da coletividade de forma mais incisiva.

Mas não foi a partir do século XIX que Joana passou a figurar em meio às Histórias de França. Já entre 1643 e 1651 Mézeray publicou História da França de Pharamond até os nossos dias ${ }^{110}$ e nela dedicou uma parte à Joana. Sua obra foi muito citada nas Histórias de França do XIX. Há um ingrediente novo, uma vez que essas obras sofrem influência do Romantismo: "é um gênero literário tão jovem quanto a ideia de nação, o romance, que vai ao mesmo tempo servir de modelo narrativo para as primeiras elaborações eruditas de histórias nacionais e de formidável vetor de difusão de uma nova visão de passado."111

A influência das obras de Walter Scott é uma das características importantes das Histoires de France do século XIX, segundo Anne-Marie Thiesse. A partir dessa influência as histórias nacionais vão apresentar uma causalidade entre os fatos ligados

\footnotetext{
${ }^{109}$ MICHELET, op. cit., p. 7.

110 "Em suas diversas variantes, essas obras tinham uma grande influência sobre a sociedade, seja pela via a da historiografia científica depois da Idade Média, ou sob a forma condensada de narrativas (abregée) depois do fim do século XVI. Elas se tornaram uma instituição política oficial depois da criação de um governo monárquico absoluto.” KRUMEICH, G. op. cit. p. 121. Tradução nossa.

111 THIESSE, Anne-Marie. La création des identités nationales. Editions du Seuil, 2001. p. 134.
} 
em uma intriga romanesca, jogando com efeitos de tensão e resolução. O caráter muitas vezes didático desses romances também vai seduzir os historiadores. Com descrição de objetos roupas, em histórias que mesclam personagens históricos com fictícios eles serão admirados por historiadores como Thierry: “(...) é em um romance que se deve esclarecer esse grande ponto da história e se preservar viva e nua essa conquista normanda."112

Em relação à Joana d'Arc essas histórias nacionais têm papel de primeira importância. Segundo Winock foram as Histórias da França do século XIX que familiarizaram os franceses com a Donzela ${ }^{113}$. Existem, porém, elementos de biografia em meio a uma história nacional - apesar da forma como se escreve ter sido modificada - os topoi típicos dos modelos biográficos subsistem. Esses traços, no entanto, manifestam menos virtudes pessoais do que "o indefectível querer-ser da França." 114

Tanto nas Histórias da França quanto em obras de caráter mais específico em que se narrou a vida de Joana d'Arc, ela, como indivíduo de destaque, se manteve como uma heroína, que no século XIX se tornou nacional. Apesar de haver uma tradição em relação à figura do herói, esse século trouxe uma mudança em relação ao seu significado. Há um deslocamento semântico do termo herói que antes designava os semideuses da antiguidade e que, a partir do século XVIII, passa a identificar tão somente o personagem principal da narrativa. A novidade dos Oitocentos é que mais um ingrediente é acrescentado a essa ideia: “A Revolução que se apresentava como

\footnotetext{
112 THIERRY, A. Ouevres complétes. Paris: Garnier: 1867.

${ }^{113}$ WINOCK. M. op. cit.

114 FABRE, Daniel. L'atelier des héros. In: CENTILIVRES, Pierre; FABRE, Daniel; ZONABEND, Françoise (orgs.). La fabrique des héros. Paris: Éditions de la Mason des sciences de l'homme, 1998. P. 180
} 
prolongamento da vontade do povo não poderia renegar a si própria retomando o mito heróico tal qual ele era: precisava conferir-lhe um novo significado."115

Com o Romantismo, a ideia de heroísmo ganha novos contornos e tem uma grande influência na historiografia para qual o acontecimento individual passa a ter grande importância. Para Carlyle, por exemplo, a história tenta revogar o que chama de o "Edito do Destino." Segundo ele o historiador deveria dar voz aos mortos como uma forma de advertir os vivos. Além disso, na história vivida cada acontecimento singular é o resultado de outros que se recombinam para gerar novos: "é um Caos do Ser permanente."

\begin{abstract}
"Para Carlyle, então, adquiri-se o conhecimento histórico mediante a simples perquirição do 'Caos do Ser' a fim de determinar os pontos em que determinados indivíduos excepcionais apareceram e impuseram sua vontade a uma turba indolente e recalcitrante. $\mathrm{O}$ aparecimento do herói representa uma vitória do Livre Arbítrio humano sobre a necessidade. A tarefa do historiador é compor um hino em honra ao herói ." 116
\end{abstract}

Percebe-se que essa ideia se assemelha muito àquelas desenvolvidas por nossos autores em relação à Joana d'Arc. Encarnação de uma vontade geral, vinda em um momento sombrio da história, de verdadeiro caos, Joana é capaz de revogar a sentença de morte que havia se anunciado para a França e impõe a partir de sua vontade a verdade na qual acreditava, a de que Carlos VII deveria ser coroado rei e os ingleses deveriam ser expulsos da França.

Outras ideias desenvolvidas por Carlyle contribuem para compreendermos o progressivo interesse por Joana d'Arc nascido entre os historiadores da primeira metade século XIX e a forma como abordaram sua trajetória. O problema da função da história

\footnotetext{
${ }^{115}$ DOSSE, F. op. cit. p. 161

${ }^{116}$ WHITE, op. cit. o. 158-159.
} 
para a humanidade é uma delas: ela deve dar ao homem a consciência de seu heroísmo. Mas o herói é aquele que encarna o universal, e foge às injunções o tempo, segundo ele "a História do mundo nada mais é do que a biografia dos grandes homens" $" 117$. Seu herói é contra o egoísmo da individualidade, alguém que renuncia a si mesmo. Nesse sentido, Joana é a heroína perfeita, a história de sua vida é a história da França. Nos nossos autores isso aparece resolvendo a tensão que poderia se colocar entre as exigências de uma biografia que quase desaparece por acabar se fundindo à história de um país.

O século XIX conviveu ainda com a figura do "grande homem". O herói não desaparece e a identidade patriótica exalta os valores heróicos de determinadas figuras. Os valores são a temeridade, a coragem e a disposição ao sacrifício em prol da mensagem da República. Esse é o caso não só de Joana d'Arc, mas também de Du Guesclin, Bayard e Napoleão. Esse heroísmo não se distancia da ideia de grande homem, na medida em que ele se define por coincidir sua determinação pessoal com a vontade coletiva de uma época. O grande homem não é portador do Divino, mas da alma nacional.

A influência da filosofia de Victor Cousin se deu na medida em que ele definiu a ideia de grande homem relacionando-a ao povo, visto como uma unidade ideal. O grande homem harmoniza a particularidade e a generalidade. Essa dialética individual/geral cria o grande homem: “(...) a humanidade não tem tempo a perder com pessoas que são apenas indivíduos. Um grande homem, senhores, está distante ao mesmo tempo da criatura original e do tipo vulgar. É povo e ele mesmo, conjuntamente." $" 118$

\footnotetext{
${ }^{117}$ CARLYLE. Les héros.(1841) Maisnoneuve et Larose, 1998. p. 55. Tradução nossa.

${ }^{118}$ COUSIN, V. Introduction à l'histoire de la philosophie. 1828. p. 174. Tradução nossa.
} 
A influência de tais ideias na historiografia do período é flagrante. Thierry, por exemplo, muda o foco das elites em direção ao Terceiro Estado, o povo. Trata-se de um contraponto à glorificação dos heróis. Para Dosse é uma ânsia democrática de dar um lugar às massas. Mas em nossa opinião é um elemento de conservação, tentativa de caracterizar o Terceiro Estado com o grupo não radical da Revolução.

Em relação à Joana d'Arc vemos uma clara influência de todas as ideias apresentadas acima, muito importante para criar uma ideia de heroísmo que irá compor sua imagem no século XIX. Além disso, vários elementos tradicionais recorrentes ao heroísmo são associados a ela: a presunção de um nascimento ilegítimo com ascendência real, o rápido aprendizado do ofício das armas - o que levou Christine de Pisan a considerá-la melhor do que Aquiles e Heitor -, a existência de objetos miraculosos, no caso de Joana a espada encontrada em Sainte-Catherine-de-Fierbois e seu estandarte, e a existência de profecias que anunciaram seu surgimento. Uma das características atribuídas aos herois da Antiguidade que é muito explorado pelos biógrafos de Joana d'Arc seria a moderatio, característica fundamental de um líder cuja principal função seria zelar pela salvação do exército optando pela prudência defensiva. Embora fosse uma liderança guerreira, Joana sempre aparece nas obras buscando a pacificação, tentando negociar com os oponentes. Trata-se de um ponto importante na tradição retórica em relação às vidas de herois que mesmo guerreiros, agiam guiados pela prudentia colocando a paz acima de todas as coisas. Esse ponto foi muito explorado pelos autores que narraram a vida de Joana d'Arc sendo levado ao extremo, uma vez que a Donzela também se preocupava com a salvação da alma dos ingleses. Dessa forma compreendemos a importância angular da famosa "Carta aos ingleses" ditada por Joana em 22 de março de 1429, antes, portanto da batalha de Orléans. Nela a 
Donzela pede aos comanantes ingleses que voltem para sua terra, dando-lhes a oportunidade de partir sem derramamento de sangue ${ }^{119}$. Essa carta foi considerada um documetno fundamental para compreender as ações de Joana d'Arc, não só pelas informações e importantes referências nela contidas, mas porque confirmava historicamente um atributo moral fundamental para a identificação de um verdadeiro herói.

Mas o mais fundamental no heroísmo de Joana para nossos autores parece ter sido as consequências gerais de sua personalidade e atuação. O questionamento seguinte se insere de forma enriquecedora em nosso debate.

“A valorização do herói leva ao extremo a tensão entre o particular e o universal. Até que ponto o herói é a mera encarnação de suas qualidades específicas e de que maneira exprime uma dimensão mais geral, que o ultrapassa e transcende?"120

A dificuldade dos autores em resolver tal tensão se expressou no momento de se escrever a história de Joana, em que os autores optaram por trazer elementos biográficos na medida em que esses identificavam sua singularidade, que reside justamente na abnegação da Donzela em relação à sua vida particular em prol do benefício nacional.

François Dosse define a biografia como um gênero híbrido, uma vez que se coloca entre o real e vivido e o pólo imaginativo do biógrafo. Trata-se de uma tensão que não é exclusiva da biografia, mas que em seu caso é levado a um paradoxo. Considerar o aspecto biográfico da narrativa sobre Joana d'Arc em meio às "Histórias de França" nos leva a perceber essa necessidade de ficção e estética que se introduzia nessas obras comprometidas em narrar sua epopeia. Como uma regra geral da biografia,

${ }^{119}$ Todos os autores que analisamos nessa tese trazem uma reprodução da "Carta aos ingleses" de 1429.

${ }^{120}$ DOSSE, F. op. cit. p. 151 
André Maurois ${ }^{121}$ percebe que o herói nunca deve desaparecer no pano de fundo. Mas como lembra Dosse, algumas vezes evoca-se o desejo de fazer jus à memória do biografado, em outras ele é só um pretexto para resgatar um momento.

Algo que caracteriza a história de Joana d'Arc é o fato de sua vida pública só existir atrelada a fatos da história francesa. Além disso, essa vida pública, como bem lembra Colette Beaune, é muito bem documentada. Quando consideramos esse fato, tendo em vista o aspecto biográfico exigido quando se narra sua vida, vemos que os autores procuram atestar essa verdade, trata-se de uma biografia que não deve atender apenas à arte, ela necessita de um método histórico. Temos em relação à Joana um uso frequente de seus processos de condenação e de anulação da condenação como fonte para as principais passagens de sua vida, o que levou o próprio Lebrun des Charmettes a dar para sua obra o título: História de Joana d'Arc tirada de suas próprias declarações. Dessa forma o pacto de veracidade característico do gênero ${ }^{122}$ sofre, em relação às narrativas sobre a Donzela, a pressão da farta documentação ao mesmo tempo em que se fortalece em função do mesmo fato.

Maurois lembra que esse pacto de veracidade coloca o biógrafo numa posição menos livre do que o romancista, uma vez que esse tem liberdade para falar da vida interior de seu personagem. Lembremos que, em relação à Joana, mesmo essa farta documentação esbarra em um problema enfrentado pelos seus biógrafos: Joana realmente ouvia vozes? Essas vozes eram fruto de sua imaginação ou realmente divinas? Essa vida interior do personagem em se tratando de Joana d'Arc, além de não poder ser acessada pelos escritores, exigia deles uma habilidade não só para explicá-la

\footnotetext{
${ }^{121}$ MAUROIS, A. Aspects de la biographie. Grasset, 1932. Tradução nossa.

${ }^{122}$ DOSSE, F. op. cit. MAROIS, op. cit.
} 
como também para não permitir que esse mistério atrapalhasse a importância da história da Donzela de Orléans para a França.

Referindo-se às biografias, Dosse esclarece que "O desejo de definir com a máxima clareza os contornos do indivíduo fez a glória de uma escrita do minúsculo, do ínfimo, do aparentemente insignificante." ${ }^{123}$ Mas em relação à Joana d'Arc essa escrita do minúsculo é para enquadrá-la no geral, o detalhe é importante para um sentido maior. Suas biografias estão fatalmente marcadas não só por uma tensão entre o real e o imaginário, mas também entre o particular e o geral que, no século XIX, se configurou na sua presença nas Histórias da França. Sem dúvida a entrada de Joana com cada vez mais espaço nessas histórias é fruto da ressignificação de sua imagem que passa a ter caráter nacional, o que já se percebe em Lebrun des Charmettes.

Nesse sentido, temos um novo papel reconhecido pelas biografias no século XIX: a sua função pedagógica na tentativa de formar cidadãos a partir da ideia de unidade trazida pela vida do herói nacional. Essa ideia está sem dúvida muito presente nas obras que tratam de Joana d'Arc, sendo uma das formas de sua ressignificação a relação entre o individual e o coletivo. Nossa heroína se apresenta nessa tensão entre particular e o geral a partir de uma noção que não surgiu no século XIX, mas que foi ressignificada por ele: o entusiasmo.

\section{3 - A ressignificação do entusiasmo}

Analisando o processo de condenação de Joana d'Arc, L'Averdy considera que a firmeza de suas respostas indicava que a Donzela era movida por uma espécie de obstinação. Suas palavras pareciam estar animadas por "exaltações de espírito das quais

${ }^{123}$ DOSSE, F. op. cit. p. 69. 
é capaz uma imaginação tão suscetível como parece ter sido a sua." ${ }^{124}$ De fato, muitos autores se preocuparam em explicar de uma forma racional não só a firmeza e clareza com que Joana se portou diante dos juízes, mas também seu espírito de liderança.

Berriat Saint-Prix, por exemplo, tentou mostrar que as ações de Joana não tiveram causas maravilhosas, e sim naturais. Ela possuía algo que faltava ao rei e à sua corte: a coragem no coração. Por isso em sua contemporaneidade ela foi vista por muitos como feiticeira e maga, e os franceses realmente acreditavam em sua inspiração e missão divinas. No entanto, por mais que se deva considerar que tudo acontece por desígnio da Providência, não se deve buscar a explicação dos eventos através da maravilha quando é possível dar uma explicação natural para eles.

Sua interpretação vai na direção de contextualizar o evento:

"Não se deve levar em conta a época em que viveu? É justo transportar o século XVIII para o começo do XV e transformar em filósofos uma pobre camponesa e soldados grosseiros? (...) Naquele período a superstição era uma doença universal, nutrida pela ignorância. Nascida em meio às guerras civis e estrangeiras travadas em meio ao ódio pelos ingleses, testemunha das devastações contínuas de seu país, em meio a males que pareciam não ter fim é tão extraordinário que sua imaginação exaltada e ardente converteu muitas vezes durante o sono suas esperanças em realidade, e que por fim, dotada de muita coragem ela quisesse executar o que acreditava de boa fé ser uma inspiração da Providência? (...) Quanto à eloqüência, seus discursos rústicos sem correção e ornamento, só oferecem aquilo que há na natureza fortificado pela persuasão e pelo entusiasmo." 125

\footnotetext{
${ }^{124}$ L'AVERDY, op. cit. p.57. Tradução nossa.

${ }^{125}$ Idem, p. 60-61.
} 
O entusiasmo seria a crença absoluta de Joana em sua missão, o que a levava a dar respostas desconcertantes mediante os teólogos do Tribunal da Santa Inquisição. Da mesma forma que sua atitude entusiasta em Chinon a levou a reconhecer o Delfim disfarçado em meio a outros nobres, ela the garantia eloquência nas respostas ao longo do processo. Portanto frases como "Eu não sei A ou B; eu venho da parte do Rei do Céu para levantar o cerco de Orléans e levar o Rei a Reims" estavam embebidas em seu entusiasmo: " em cada resposta a mesma simplicidade, a mesma segurança, e às vezes essa eloquência que, se deve repetir, resulta do entusiasmo. "126

Esse entusiasmo não era retido por ela, mas era transmitido a todos: "Através de seu aspecto, de seus discursos o entusiasmo ia do exército à guarnição e aos habitantes; a cidade se torna então invencível.” Nas batalhas “(...) os soldados ficavam eletrizados pela audácia de Joana (...)" 127 Assim se define seu heroísmo, fundamental na vitória francesa em Orléans:

“(...) devido a rapidez dos eventos pelos prodígios acumulados sobre prodígios nós quase convertemos essa parte de nossa obra em uma simples descrição. Mas seguindo um outro método poderíamos ter melhor celebrado nossa heroína?" 128

Se Carlos VII triunfa é "graças ao desenvolvimento de seus guerreiros e de seu povo, a eventos fortuitos e jamais a seus trabalhos ou esforços." ${ }^{129}$ Saint-Prix afirma que em várias expedições Carlos VII não demonstrou liderança, não foi até os aliados e dessa forma antigos defensores de sua coroa deixaram de apoiá-lo. Carlos VII preferia dar festas a organizar uma batalha. Quando descreve o ataque a Orléans de 1428, SaintPrix questiona: “(...) homens, mulheres, vilões, crianças todos se juntaram ao exército.

\footnotetext{
${ }^{126}$ SAINT-PRIX, op. cit., p. 312. Tradução nossa.

${ }^{127}$ Idem. P. 64-65. Tradução nossa.

128 SAINT-PRIX, B. op. cit. p. 73. Tradução nossa.

${ }^{129}$ Idem, p. 36. Tradução nossa.
} 
Generosos cidadãos onde estava vosso príncipe?" 130 Sobre a atitude de Carlos por ocasião do Cerco de Orléans ele se incomoda:

“(...) a conduta de Carlos é que fornece ampla matéria se não se sentir uma espécie de aborrecimento e quase desgosto ao apresentar um príncipe que conserva tanta apatia entre indivíduos que se distinguem por tantas realizações. Tudo o que se obteve dele foi que viesse a Loches que se aproximasse alguns quilômetros de Orléans. Indigna-se diante de uma tal inércia logo que se examina a atividade de Joana d'Arc. "131

A inércia de Carlos se contrapõe à ação de Joana. Facilmente manipulável, Carlos VII é apresentado como um joguete nas mãos de La Trémoille. Mas a visão do autor em relação à monarquia é mais complexa. Ele apresenta várias críticas ao comportamento indolente desse rei, no entanto, após narrar a morte de Joana sua obra se dedica a um verdadeiro elogio à Carlos VII. As vitórias de Joana haviam servido para minimizar o poder do adversário, assim restava ao rei tão somente terminar o trabalho já começado por ela. Após a morte da Donzela ele se cerca de ministros esclarecidos e assim suas decisões passam a ser norteadas pela equanimidade: "Verdadeiro pai de seus súditos, o desejo de conservar sua linhagem e seu descanso o levava a não precipitar suas expedições."132

Suas medidas servirão para pacificar e reorganizar o reino:

"As exações são reprimidas, os problemas pacificados; os tribunais, cuja autoridade não era reconhecida há muito tempo, voltam a atuar. E ele não se limita a isso: colocando os olhos no futuro, ele ordena que se escrevam os incontáveis costumes que serviriam de leis, ou ainda de meios de regulação, a dois terços da França. Ele tem assim a glória de lançar os fundamentos de um edifício indispensável à nossa felicidade, mas tão difícil de se construir que por três séculos e meio se procura com

\footnotetext{
${ }^{130}$ Idem, p. 53. Tradução nossa.

${ }^{131}$ Idem, p. 73. Tradução nossa.

${ }^{132}$ Idem, p. 81. Tradução nossa.
} 
dificuldade acrescentar pequenas continuações ou restaurações e é necessário que aconteça nada menos do que a maior das revoluções para terminá-lo. "133

À margem direita desse parágrafo Saint-Prix lê-se: “Código Civil.” Sua defesa do absolutismo fica clara nesse trecho em que reforça a ideia de que o povo e o país nada são sem uma autoridade pública forte. Mas em relação à atitude de Carlos VII na ocasião da prisão de Joana em Compiègne e seu cativeiro em Rouen, Saint-Prix volta a criticá-lo:

"Durante essas longas e dolorosas angústias de Joana d'Arc o que fazia o príncipe que ela havia recolocado no trono? (...) Acaso ele usou todos os seus recursos para resgatar sua libertadora dos atentados aos quais estava ameaçada? (...) envergonho-me por não ter nada a responder em defesa de Carlos VII. "134

Apesar de apresentar os argumentos de l'Averdy que poderiam livrá-lo de uma culpabilidade, ele considera que Carlos VII abandonou Joana d'Arc, "mulher ilustre e desafortunada" ignorada pelo seu "ingrato soberano.",135

Para justificar suas afirmações sobre Carlos VII, ele cita uma fonte do século XIV, o "Elogio a Carlos VII", de autoria desconhecida. A partir de um cruzamento desse texto com outros documentos, como as atas da Assembleia dos Estados Gerais de 1484, Saint-Prix afirma ser possível concluir que as medidas de Carlos VII de fato trouxeram melhoria para a França.

Para compreender essa aparente contradição no raciocínio de Saint-Prix no que se refere à relação de Joana d'Arc com Carlos VII, temos que levar em conta que seu

\footnotetext{
${ }^{133}$ Idem, p. 84. Tradução nossa.

${ }^{134}$ Idem, p. 93. Tradução nossa.

${ }^{135}$ Idem. Tradução nossa.
} 
alvo não é o rei em si, mas a monarquia. Ao desenvolver o tema do entusiasmo, SaintPrix o associa irremediavelmente à defesa da Coroa. Mesmo na fogueira de Rouen, Joana defendia Carlos VII, ela não se dizia abandonada pelo rei: defendia a França acima de tudo e como a França era a própria monarquia, jamais teria se lamentado de abandono ou teria passado a criticar seu rei.

Poderíamos nos perguntar que lugar o povo ocupa nesse raciocínio. Qual seria o seu papel e potencial? Na verdade, em Saint-Prix, o povo só deseja um guia que tome as decisões corretas, ele não vai contra o seu rei: quando esse se mostra, quando está à frente, todos o apóiam. Melhoria nas leis, na economia, nas universidades. Para ele essa mudança pela qual passa a realeza francesa a partir das ações de Joana d'Arc prova que: "Nada é tão infeliz quanto o povo abandonado aos ministros e aos cortesãos! Nada tão feliz quanto um povo cujo bom rei governa por ele mesmo!" 136

No entanto, a grande responsável por isso foi Joana que, com seu entusiasmo, tinha o poder de aglutinar todos em torno de si. Não se trata de uma crítica à monarquia, mas sendo esse cargo ocupado por um homem fraco, a França e seu povo só têm a perder. As revoluções às quais ele se refere no título de sua obra - Jeanne d'Arc ou coup d'oeil sur le revolutions de France au temps de Charles VI et Charles VII et surtout de la Pucelle d'Orléans - acontecem quando o povo age de acordo com seu líder.

A luta de Joana, entretanto, e o entusiasmo que a impulsionou não devem ser confundidos com a violência das revoltas camponesas daquele período. Essas foram movidas por um espírito de ferocidade, que levava as pessoas a atacar os nobres e a queimar padres. Certamente essa não era a revolução por ele descrita. À essa reação de violência se opõe a ação de apoio irrestrito à monarquia tal como se configura em Joana 
d'Arc. A violência é consequência de um povo abandonado aos regentes, aos ministros, sem a autoridade real. A fonte de seu entusiasmo foi o civismo ${ }^{137}$, ou seja, a crença naquela forma de governo e a defesa em relação a ele.

L'Averdy também se referiu à ligação entre Joana e a monarquia para indicar uma relação ideal entre o povo e seu rei, “príncipe ao qual ela continuou ligada até seu último suspiro." 138 Ele busca justificar o fato de Carlos VII nada ter feito para libertar Joana d'Arc através de vários argumentos, dentre os quais o fato de que Carlos poderia ser visto como seu cúmplice e sendo aquela uma época de ignorância todos iam associálo a uma herege. Isso poderia "destruir o laço tão natural que liga os súditos, e principalmente os franceses ao seu legítimo soberano." 139

Já em Lebrun des Charmettes o tema do entusiasmo também está associado a uma interpretação da monarquia na época de Joana d'Arc. $\mathrm{O}$ alinhamento dos borguinhões ao lado dos ingleses é visto como prova da fragilidade dos franceses quando o rei perde sua autoridade, como aconteceu na época de Carlos VI: “(...) povo tão fácil de ser conduzido ao erro, mas que dificilmente perde seu amor por seus mestres legítimos." ${ }^{140}$ Ele defende sistematicamente o Delfim de várias acusações, inclusive pela morte de João sem Medo, citando principalmente a obra de David Hume para elogiar o rei ${ }^{141}$. Foram as circunstâncias que o tornaram escravo dos que o rodeavam já que era uma "alma naturalmente fácil de desencorajar"142.

\footnotetext{
137 “(...) se Joana pôde se deixar fascinar pela ideia de ter sido enviada pelo Eterno, essa ilusão [foi] enobrecida por outro lado pelo civismo que foi sua fonte.” SAINT-PRIX, B. Op. cit. p. 10. Tradução e grifo nossos.

${ }_{138}^{13}$ L'AVERDY. p. 168. Tradução nossa.

${ }^{139}$ Idem, p. 161. Tradução nossa.

${ }^{140}$ CHARMETTES, L.op. cit. p. 47. Tradução nossa.

${ }^{141}$ HUME, D. The History of England from the Invasion of Julius Caesar to the Revolution in 1688, Foreword by William B. Todd, 6 vols. (Indianapolis: Liberty Fund 1983). Vol. 2. Chapter: XX: HENRY VI. Accessed from http://oll.libertyfund.org/title/789/67294 on 2010-10-25.

${ }^{142}$ CHARMETTES, L. op. cit. p. 90. Tradução nossa.
} 
Para Charmettes, o entusiasmo vem do amor entre o rei e o povo e da fidelidade desse povo para com o soberano. Quando os ingleses ameaçam Orléans, ele diz que Salisbury pensava que ia encontrar apenas dois mil homens para combater. “(...) ele ignorava que perto ao perigo, quando se ama seu rei, todo francês é guerreiro." ${ }^{\prime 43}$ Ele se esforça, como vimos, para enquadrar a história em um modelo, o modelo da epopeia, e por isso faz a comparação das batalhas de Joana d'Arc com os combates gregos, buscando uma semelhança com os épicos, em especial as batalhas da Ilíada. Sua descrição do cerco de Orléans vai da página 115 à 220 do tomo I, expressando a ideia de que o grande número de páginas era comparável à grandiosidade da história.

Esse autor encara as ações de Joana como obra da Providência:

“(...) a sorte futura da Europa e do mundo poderia mudar se a Providência não tivesse levado em seus ombros um desses seres impressionantes por seu gênio, maravilhosos por seu destino, que ela escolhe de tempos em tempos para serem instrumentos dessas revoluções inesperadas que confundem o orgulho dos vencedores da terra, enganam todos os cálculos da sabedoria humana e levam o pensamento do rei e dos povos aos pés do único trono inabalável e do único poder eterno."144

Assim a ação de Joana viria de uma escolha da Providência que desejava recolocar a França em contato com o poder espiritual, o único verdadeiro e inabalável. Mas, por causa disso, deve-se considerar que as ações de Joana eram miraculosas? Quando lembra que os pássaros vinham até ela, como se a reconhecessem - passagem evocada em crônicas da época - Charmettes tira o foco do miraculoso explicando que isso pode ter acontecido por questões naturais. Se ele aceitasse o miraculoso, a heroína perderia o sentido: ela deveria ser humana para ser real. Em verdade ele quer ressaltar o caráter heroico de sua personalidade.

\footnotetext{
${ }^{143}$ Idem, p, 117. Tradução nossa.

${ }^{144}$ CHARMETTES, L. op. cit. p. 220. Tradução nossa.
} 
"Duas paixões soberanas, o amor por Deus e o amor pela França se confundiam no coração de Joana d'Arc. A exaltação produzida por essas paixões, no seio da solidão, fez com que nascessem em seu espírito imagens fantásticas (...) ou Deus, tocado pelas desgraças da França envia realmente a essa jovem virgem os ministros de sua vontade?"145

É visível sua dificuldade de posicionamento em torno do assunto. Além de frequentemente dizer que ela se acreditou inspirada, o autor se questiona se essas vozes poderiam ser da Santíssima Trindade, e se pergunta sobre a possibilidade dessas imagens serem causadas pelo espírito contemplativo. Mas ainda assim o autor se detém no debate em torno dessa questão levantando a possibilidade da santidade de Joana.

Quando ela foi ferida em Orléans o autor pensa que suas palavras mais se assemelharam às de uma santa desapegada das honras e dos bens dessa vida do que às de uma heroína desejosa da glória do mundo. Charmettes não defende com clareza a ideia de canonização, porém discute a argumentação daqueles que questionavam sua santidade. Aos que diziam que Joana não foi uma santa por ter sido dominada pela ira, ele responde que Deus a permite se foram usada contra a injustiça, conforme os exemplos de Moisés e do próprio Cristo. Aos que afirmam que ela dava más respostas ele questiona: “então a perfeição pertence à humanidade? E a santidade é incompatível com leves defeitos? Assim se poderia concluir que a santidade é incompatível com a humanidade e assim não haveria santos."

O autor foge de uma sentença definitiva em relação às vozes ouvidas por Joana, o que, no entanto não o impede de usar vários argumentos para não descartar o contexto divino dos acontecimentos na vida da Donzela. Sua narrativa está muito bem fundamentada na documentação, com crítica às crônicas e aos processos, mas no caso

\footnotetext{
${ }^{145}$ Idem, p. 289. Tradução nossa.

${ }^{146}$ CHARMETTES, L. op. cit. p. Tomo V. p. 462. Tradução nossa.
} 
das vozes e da inspiração de Joana ele se vê na impossibilidade de provar qualquer coisa e se limita a colocar suas convicções pessoais como suficientes para acreditar em sua inspiração divina:

"Percebo que refutando os sistemas que atribuem os feitos da Donzela à invenção humana, eu expus suficientemente o contrário, que consistem em reconhecer neles a mão de Deus. Em relação a isso não entrarei em grandes detalhes. Que se alguém agora perguntar ao autor dessa história qual é sua opinião particular sobre Joana d'Arc e as maravilhas de sua vinda, ele se contentará em responder, em toda simplicidade de seu coração: Eu sou francês, eu sou cristão."147

Ao insistir na autenticidade dos acontecimentos em torno da história de Joana d'Arc e no fato que suas ações não eram necessariamente sobrenaturais, ele busca provar que tudo é verdadeiro, apesar de inverossímil. Assim seu argumento de uma intervenção divina é reforçado. Além disso, falar de seu comportamento como boa e verdadeira cristã é reforçar a iniquidade de seu julgamento.

De fato, a eficácia em atribuir a glória de Joana à atuação do entusiasmo parece ter sido de tal forma reconhecida por esses autores que esse tema continuaria sendo um recurso comum em muitas obras, embasando diversas opiniões como veremos a seguir.

Sismondi, como vimos, parte de um contexto geral para explicar o advento de Joana. Vinda de um meio supersticioso, influenciado pelo desejo de expulsar o estrangeiro, o "zelo popular" brilhava através dela. Algumas de suas características como a coragem, a constância, a pureza e a sabedoria se unem à sua crença no sobrenatural e produzem uma personalidade capaz de dar à multidão o poder de fazer uma grande revolução. A partir de seu meio, podem-se explicar suas visões: como frequentemente tinha contato com os rituais na Igreja em homenagem aos santos, ela

${ }^{147}$ Idem, p. 466. Tradução nossa. 
acreditava vê-los e ouvir suas vozes. Essas visões teriam começado aos treze anos, idade em que ainda não menstruava: "as enfermidades de seu sexo não a haviam atingido nessa idade. E parece que disso ela foi sempre isenta sendo essa uma das causas que a dispuseram aos êxtases e às ilusões de seus órgãos."

O sonho contínuo em ver o Delfim coroado como Carlos VII produzia os êxtases nos quais ela acreditava ver o que desejava: São Miguel, Santa Margarida e Santa Catarina. Esse sonho era causado pelo desejo de defender sua casa, sua vila, seu país contra os borguinhões e ingleses.

O que fazia com que Joana obtivesse apoio era o fato de seu entusiasmo se estender a todos os que a rodeavam. Por outro lado, devido ao espírito do tempo, a corte francesa estava disposta a acreditar que haveria uma intervenção divina a seu favor. $\mathrm{O}$ poder de Joana vinha de uma conjugação entre sua virtude, a superstição universal e a impaciência do povo em esperar por socorro.

"Humilde, modesta e de boa fé em seu entusiasmo ela não duvidava da missão que suas vozes lhe deram: libertar Orléans e levar o rei a Reims; mas ela não se atribuía nenhum poder miraculoso. (...) Sua beleza, sua doçura, suas longas orações, seu hábito de começar todos os seus discursos pelas palavras em nome de Deus, confirmaram os orleanenses na crença de que ela era uma santa, e que ela tinha o poder de fazer milagres em seu favor." 149

No início desse trecho verificamos que o autor se vale de temas da retórica biográfica - humildade, modéstia, boa fé - com o objetivo de não desqualificar o personagem devido à sua peculiaridade: a suposta capacidade de ouvir os anjos e santos. Em seguida, Sismondi articula o contexto geral às situações particulares: havia uma disposição nos espíritos para acontecimentos desse tipo. Além de transmitir entusiasmo

\footnotetext{
148 SISMONDI, S. op. cit. p. 117. Tradução nossa.

${ }^{149}$ Idem, p. 123-127. Tradução nossa.
} 
aos moradores de Orléans e ao exército francês devido a sua inclinação para acreditar em superstições, Joana causava pavor no exército inglês que a via como bruxa e feiticeira. Mesmo antes da vitória, o sucesso do exército francês era alcançado apenas pelo terror que o nome da Donzela causava nos ingleses. Ao mesmo tempo, os capitães franceses tiravam o melhor proveito possível do entusiasmo que ela trazia ao exército. Nesses dois pontos se esclarece o sucesso das expedições francesas que tinham à frente a Donzela de Orléans: os franceses venciam por estarem persuadidos da missão de Joana e os ingleses eram derrotados pelo terror supersticioso que levava ao fracasso na batalha.

No plano geral as pessoas estavam inclinadas, por um lado, à crença no sobrenatural, e, por outro lado, a tomar partido de um determinado grupo em tempos de guerra. Do ponto de vista particular, a singularidade do personagem se dá na medida em que era movida pelo entusiasmo, mas isso só poderia ser detectado pelo observador distante, posição na qual Sismondi se coloca, o qual a partir do método racional pôde descobrir efetivamente as causas do sucesso da Donzela de Orléans.

Sismondi detecta que, após a coroação em Reims, Joana começa a perder as batalhas por ter deixado de acreditar em sua missão. Citando uma crônica do período ele pretende comprovar que Joana não desejava continuar lutando após a coroação de Carlos VII: "Eu cumpri o que o Senhor me ordenou, que era levantar o cerco de Orléans e fazer sagrar o gentil rei; eu gostaria que ele me mandasse de volta a meu pai e minha mãe para cuidar das suas ovelhas e novilhos e fazer o que quero fazer."150

Trata-se de um dos pontos mais polêmicos da história de Joana d'Arc ao longo do século XIX. Quando terminou a sua missão? Seria realmente em Reims com a

\footnotetext{
${ }^{150}$ Chronique de La Pucelle, p. 351. Citado por SISMONDI,S. op. cit. p. 144. Tradução nossa.
} 
coroação do rei, ou ela deveria libertar toda a França? A única fonte que relata o desejo de Joana em voltar para casa, encerrando as batalhas, é a Crônica da Donzela citada por Sismondi, pois a partir dos processos não se pode precisar o que Joana definia como sua missão. O fato é que esse ponto obscuro deu margem a diversas interpretações, sendo que os católicos se aproveitaram para explicar o fato de Deus tê-la abandonado por ela ter extrapolado suas ordens ${ }^{151}$. Alguns vão dizer que, após o rei ter conseguido seu objetivo, a coroação, ele e a nobreza abandonam a Donzela, lhe enviando cada vez menos dinheiro e tropas, sendo essa a causa de suas derrotas. Outros, como Sismondi, afirmam que ela foi obrigada pelo rei e pela nobreza a continuar lutando, mas contra sua vontade. Essa posição, no caso de Sismondi, ajuda a reforçar seu argumento sobre o entusiasmo, uma vez que Joana ao trair sua intuição, deixa de confiar em seus próprios atos. O rei e os nobres, sabendo que seu entusiasmo contagiava o exército, exigem que ela continue a reconquista da França. “(...) ela mostra a mesma coragem nos combates, a mesma constância nas dores, a mesma confiança no bom direito da França, mas não a mesma persuasão de sua missão divina, ou a mesma fé em suas inspirações. "152

Em Sismondi a noção de entusiasmo também está relacionada à ideia de liderança. Em lugares distintos do texto o autor destaca que, por inúmeras vezes, Joana d'Arc enviou mensagens ao rei para que ele fosse ao campo de batalha encorajar seu exército. Por ocasião da batalha de Paris, em que Joana foi ferida e o exército francês derrotado, Sismondi considera que só a indolência de Carlos VII o impediu de ir até lá para animar o exército. Em relação a antigos aliados que foram deixando o partido armagnac, o autor também coloca a responsabilidade sobre Carlos VII que não acompanhava o exército e não se dirigia às cidades para reforçar os laços com a

${ }^{151}$ Cf. KRUMEICH, Gerd. "Controverses historiographiques autour de la mission de Jeanne d'Arc au XIXe siècle", Bulletin des Amis du Centre Jeanne d'Arc, nº10, 1986, p. 33-40.

${ }^{152}$ SISMONDI, S. op. cit. p. 145. Tradução nossa. 
população local. A burguesia, dessa forma desencorajada, não via no rei nenhuma garantia, não querendo se comprometer em seu nome. Parte da nobreza também se desmotivava da luta em função do comportamento de Carlos VII.

"A burguesia, a nobreza, os príncipes reais, estavam então prestes a abandonar Carlos VII, já que eles viam que esse rei já havia abandonado a si mesmo. (...) ele volta a Chinon onde recomeça a viver na moleza da qual Joana d'Arc teve tanta dificuldade para tirá-lo."153

Joana acabou ocupando o papel do líder, o entusiasta que deveria estar à frente do seu exército, transmitindo a força e a coragem necessárias em uma guerra. Enquanto Joana estava convicta de sua missão venceu as batalhas e recuperou importantes regiões reintegrando-as às posses do Delfim. Após a coroação, como não tinha mais o mesmo entusiasmo, passa a sofrer derrotas, é capturada e presa. Já que Carlos VII não tinha esse sentimento, era incapaz de inflamar qualquer ajuda a seu favor, e pelo contrário, ao se entregar a "prazeres vergonhosos", causava um desencorajamento geral.

"os franceses sentiram que não tinham nem mais monarquia ou pátria já que o representante de uma e outra não havia mais sentimento francês. Com efeito, esse não é um dos menores inconvenientes das monarquias absolutas, a influência que elas dão aos vícios de um único homem, para aniquilar o efeito de todas as virtudes, de todo o heroísmo dos seus súditos." 154

Além disso, Sismondi insiste que o rei nada fez para salvar aquela que o tinha levado à coroação. Vemos que, apesar de não podermos separar os historiadores rigidamente em dois grupos opostos, não há um distanciamento em relação a interpretações sobre as atitudes de Carlos VII. Aqueles que escrevem sobre Joana d'Arc no período da Restauração, sendo monarquistas, como é o caso de Lebrun des

\footnotetext{
${ }^{153}$ SISMONDI, S. op. cit. p. 157. Tradução nossa.

${ }^{154}$ Idem, p. 164. Tradução nossa.
} 
Charmettes e Berriat Saint-Prix, vão encontrar todos os argumentos para defender, senão Carlos VII, a monarquia absoluta enquanto uma instituição. Nesse caso Joana defende a monarquia até o fim, mesmo presa defende o seu rei e liga a monarquia francesa definitivamente a uma proteção divina que desejava que os verdadeiros reis da França assumissem seu trono legítimo.

Em Sismondi a defesa do rei naquele período era a defesa da pátria. Joana, como alguém de seu tempo, ao desejar defender seu país contra o jugo estrangeiro, deveria lutar pela monarquia; não haveria outra forma. Mas ele aproveita para criticar a monarquia absoluta que solapa a manifestação do entusiasmo. Em outros momentos Sismondi critica a monarquia absolutista pelo fato dela causar disputas palacianas entre os nobres que são movidos por interesses pessoais se envolvendo em lutas mesquinhas, apaixonadas e inconsequentes. "A batalha de Bullégneville foi causada por uma dessas revoluções palacianas ou de toucador para as quais o historiador das monarquias é forçado a levar, com vergonha, a atenção dos leitores." "155

Sua visão a respeito da monarquia e da nobreza é a de que ambas estão presas a interesses individuais, não ao bem comum. Assim, o entusiasmo do líder e o heroísmo do povo não se manifestam. O duque de Borgonha, por exemplo, estava mais preocupado com as disputas entre os príncipes do que com a França: ele vê isso como característica intrínseca a essa forma de governo e não percebe nela nada que possa ser proveitoso para o país.

A epopeia de Joana foi útil para que Sismondi estabelecesse a ideia de que o entusiasmo deveria ter inflamado o chefe do governo francês, caso ele defendesse sua pátria e não seus próprios interesses. Além disso, mostra que o povo deve saber que o 
entusiasmo pode partir dele, como se vê no exemplo de Joana d'Arc. Naquele período tanto as pessoas à sua volta quanto ela mesma interpretaram essa devoção à pátria, capaz de provocar ações gloriosas, como ação do sobrenatural, já que o período apesar de contar com uma revolução nos espíritos trazidas pelas 'luzes renascentistas' ainda não oferecia explicação aos fenômenos fora do quadro do sagrado. Assim Sismondi abre as portas para a interpretação de Michelet, vista como original, mas que para nós é fruto da ressignificação operada pelos autores que o antecederam.

Michelet se propôs a responder a uma questão: o que existia de especial em Joana d'Arc, visto que em sua própria época muitas pessoas que diziam ouvir vozes, se autoproclamando enviadas de Deus? Para Michelet a peculiaridade de Joana encontra-se em sua capacidade de criação. E é a partir dessa ideia que devemos procurar compreender a interpretação que o autor faz da história da Donzela.

Não há como passar pela história de Joana d'Arc sem levar em conta o sentimento religioso que a impulsionava. Para ele a santidade de Joana se espalhava entre o povo de modo que todos que a ouviam falar ficavam certos de que ela tinha parte com Deus. Mas em que consiste essa santidade de Joana para Michelet? O poder de criação em Joana d'Arc foi o responsável por todo seu sucesso.

"A jovem menina, de sua parte, criou por assim dizer, e realizou suas próprias ideias, ela fez dela seres, ela lhes comunicava do tesouro de sua vida virginal, uma esplêndida existência.(...) A originalidade da Donzela, o que fez o seu sucesso, não foi tanto a sua bravura ou suas visões, foi o seu bom senso. Graças ao seu entusiasmo, essa moça do povo vislumbrou o problema e soube resolvê-lo. O nó que os políticos e os incrédulos não podiam desatar, ela cortou. Declarou, em nome de Deus, que Carlos VII era o herdeiro." 156

${ }^{156}$ MICHELET, Jules. Jeanne d'arc..., p. 27 
Como vemos, o tema do entusiasmo também é base para Michelet construir a imagem de Joana d'Arc. Ele retoma a ideia de um entusiasmo aliado a um bom senso, já existente na obra de Sismondi, e lhe dá novos contornos, pois, em Michelet, o entusiasmo de Joana relacionava-se ao fato de ela ser uma criança. "Uma criança de 12 anos, uma jovenzinha, confundindo a voz de seu coração com a voz do céu, concebe a ideia estranha, improvável, absurda, se preferirem, de executar aquilo que os homens não podem mais fazer: salvar seu país."157

Para entender essa característica peculiar de Joana devemos ter em mente que Michelet via a criança como um ser completo, ao mesmo tempo homem e mulher. Nessa completude o bom senso, vindo do lado masculino, unia-se ao entusiasmo, que predomina no seu lado feminino ${ }^{158}$. Ao ter Joana como uma criança, percebemos que o argumento da ausência do ciclo menstrual é retomado em outros termos, mas da mesma forma é uma característica particular que explica seu impacto no âmbito geral.

Em Michelet o tema do entusiasmo também é crucial para se entender as ações aparentemente miraculosas. No prefácio da edição da Histoire de France, de 1869, ele faz um apanhado de sua caminhada historiográfica, e sobre sua relação com Joana d'Arc esclarece:

"Admirando, amando essa personalidade sublime eu mostrei até que ponto ela é natural. O sublime não está fora do natural, a multidão é um herói. A personalidade encantadora dessa jovem camponesa era o centro e reunia tudo. Ela agiu justamente porque não possuía nenhuma arte, nenhuma taumaturgia, magia ou milagre. Seu encanto é sua humanidade. Ela não tinha asas, esse pobre anjo; é o povo, é fraca, ela somos nós, ela é todo mundo. $" 159$

\footnotetext{
${ }^{157}$ Idem.

${ }^{158}$ BARTHES, Roland. Michelet. São Paulo: Companhia das Letras, 1991.

${ }^{159}$ MICHELET, J. 'Prefácio de 1869 à l'Histoire de France'. In:
} 1839. Flammarion, 1996. T. IV. p. 23. Tradução nossa. Oeuvres Complétes. 1832- 
O tema do entusiasmo de Joana d'Arc em Michelet associa-se a um assunto de repercussão nas discussões políticas do século XIX, em que conservadores e até liberais sustentavam que as massas eram movidas por uma espécie de insanidade. Michelet defendia a insanidade heroica do povo, ao contrário de muitos intelectuais que viam nessa característica uma fraqueza perigosa que tornava necessária a presença de um guia para conter os excessos passionais da massa.

Uma característica básica da insanidade, segundo as pesquisas médicas do período, era seu caráter de contágio. As ideias não seriam meras predisposições, mas poderiam ser transmitidas de uma geração para a outra. A psicologia e a fisiologia do período diziam que as ideias saudáveis poderiam ser transmitidas entre as pessoas. Dessa forma Michelet vê a insanidade heroica do povo como contagiosa e Joana d'Arc torna-se o maior exemplo dessa associação: "Essas assim chamadas leis biológicas faziam parecer certo que o exemplo de Joana d'Arc, poderia se espalhar através da sociedade e então suceder às gerações."160

A originalidade de Michelet consiste em reavaliar a atuação daqueles que foram vistos como incompetentes pela sua insanidade. Ele redefine esse conceito afirmando que as massas estavam à frente dos processos históricos. O povo continua insano, mas o desejo monomaníaco por liberdade representava as paixões que poderiam trazer liberdade à França.

As discussões sobre o entusiasmo de Joana estavam como se vê, em consonância com a ciência do período. Ícones como Pinel, no contexto da Revolução Francesa,

\footnotetext{
${ }^{160}$ CHASE JR., Richard. "Jules Michelet and the Nineteenth-Century Concept of Insanity: A Romantic's Reinterpretation". In: French Historical Studies, Vol. 17, No. 3. (Spring, 1992), pp. 725-746. P. 726. Tradução nossa.
} 
fizeram pesquisas sobre a insanidade com grande preocupação em definir questões a respeito do contágio. Para os fisiologistas as ideias obsessivas eram transmitidas em momentos críticos do ciclo biológico feminino: a menstruação e a concepção. A monomania, porém, era contagiosa não só individualmente, mas também poderia ser transmitida a uma civilização inteira. A mulher tem papel importante dentro dessa perspectiva uma vez que é vista como veículo do progresso da humanidade. "O sofrimento feminino, físico e mental, era transformado em força, porque a mulher em última instância era responsável por transmitir as ideias de liberdade e sacrifício para seus filhos." 161

Alienistas do período como Pinel e Trélat se preocupavam também com a transmissão do que eles definiam como "ideias não saudáveis." Mas havia uma chance de se curar a sociedade francesa por um processo que eles definiam como "tratamento moral" com a substituição das obsessões perniciosas pelas saudáveis.

A partir dessas ideias Michelet define quatro momentos chave de transmissão da ideia de liberdade a partir da insanidade revolucionária do povo. Esse processo teria sido deflagrado na Guerra dos Cem Anos: "Joana d'Arc começou esse processo e sua rebelião se tornou contagiosa no século XIV."162 A transmissão geracional da ideia de fraternidade teria se dado ainda em outros momentos: nas guerras de religião, no período da regência durante a menoridade de Luís XV e na Revolução Francesa. A insanidade teria levado à superação da dor nesses momentos de dissolução através da fraternidade: a insanidade gerou uma revolta contra a dor da opressão. O desejo de fraternidade é por si só ilógico, é uma questão de fé, vindo a sabedoria da insanidade popular e sendo essa a causa da Revolução de 1789.

\footnotetext{
${ }^{161}$ Idem, p. 727.

${ }^{162}$ Idem. Tradução nossa.
} 
No contexto da Guerra dos Cem Anos

“(...) a disputa com a Inglaterra foi um grande favor para a França; as províncias encontraram entre si o povo. Foi vendo a si mesmos perto dos ingleses que eles sentiram estar na França. É com as nações que o individual sabe e distingue sua personalidade pela resistência daquilo que ele não é." 163

Essa identificação nacional foi sendo transmitida até culminar nos eventos de 1789. "A Revolução Francesa representava a culminância do despertar do povo, uma cura que começou na Guerra dos Cem Anos." ${ }^{164}$ Dessa forma, o raciocínio de Michelet vai na direção oposta a de Berriat Saint-Prix para quem o entusiasmo de Joana d'Arc não teria nenhuma relação com o sentimento iconoclasta dos eventos de 1789: não representaria o desejo de um rompimento, e sim de que as coisas retornassem para seus devidos lugares ${ }^{165}$.

Para Michelet a insanidade e a loucura manifestaram-se, no século XIV, na revolta contra as autoridades brutais, e assim o povo reconheceu que desejava a unidade da nação. Essa unidade é a referência emocional que conforta o indivíduo diante da ruptura com os velhos padrões. No século XIV a insanidade era espelhada no rei louco Charles VI e o sentimento geral de unidade se encerrava em Joana d'Arc. O progresso da França ocorreu precisamente devido a essa confrontação dolorosa da vontade saudável de Joana versus a vontade doente de Charles VI. A cura da França veio de uma combinação de um tratamento psicológico e físico iniciado por Joana d'Arc: “A

\footnotetext{
${ }^{163}$ MICHELET, J. Histoire de France. 15: 345. Tradução nossa.

${ }^{164}$ CHASE JR., op. cit. p. 742. Tradução nossa.

${ }^{165}$ Cf. discussão na página 59.
} 
Donzela sozinha, teve esse conselho e essa insanidade heroica, era a própria sabedoria."166

Michelet associa Joana definitivamente ao povo ao desenvolver o tema do entusiasmo em suas obras. Joana então não é tão somente um indivíduo já que é uma representante, ou melhor, manifesta uma qualidade inerente às massas. Assim Joana é o povo que assume, a partir do entusiasmo, seu potencial revolucionário. "Ocorre em nacionalidade o mesmo que ocorre em geologia: o calor está em baixo. Quanto mais se desce, mais ele aumenta; nas camadas inferiores é escaldante.”167. Ao contrário do que havia afirmado Saint-Prix, para quem a revolução operada por Joana foi a defesa do statuos quo, ou seja, da monarquia, para Michelet, a Donzela expressou o potencial revolucionário de um povo que desejava modificar a estrutura opressiva da sociedade.

A ideia de criação é, portanto uma ressignificação do entusiasmo. Assim se estabelece a relação Joana/entusiasmo/unificação. Em Michelet a questão individual versus geral é levada ao campo da história em termos de uma unicidade que viria do todo e não das partes. O individual é importante na medida em que é símbolo da unidade que todas as coisas querem ter. A individualidade das partes é apenas aparente e o historiador teria a missão de promover essa unidade, sendo que tudo o que aparece na história deve ser julgado em função de sua contribuição ou não para tal unidade.

Michelet, na medida em que fala de Joana como dotada de bom senso no entusiasmo, estabelece uma relação entre o entusiasmo e unidade nacional. E, para ele, esse entusiasmo é o mesmo da tomada da Bastilha, Joana se faz presente nessa hora, "momento de dissolução de todas as diferenças", enquanto na fogueira de Rouen se

\footnotetext{
${ }^{166}$ MICHELET, J. Histoire ... p. 249.

${ }^{167}$ MICHELET, Jules. O Povo. São Paulo: Martins Fontes, 1988. p. 103.
} 
estabelece a relação entre o entusiasmo e nação: pela força do coração o caos das províncias se tornou uma nação.

Enquanto a união de entusiasmo e o bom senso fazem de Joana uma encarnação da ideia de unicidade, a atitude de seu rei e da nobreza em relação a ela é contrária, dando uma ideia de fragmentação: "O bom Carlos VII nada fez por ela, o bom duque Filipe entregou-a. A casa de Anjou queria a Lorena, o duque de Borgonha, o Brabante; ele queria principalmente a continuação do comércio flamengo com a Inglaterra" ${ }^{\natural 68}$.

A interpretação de Michelet em relação à Joana d'Arc é sempre lembrada tendo em vista sua originalidade, mas como vimos, ela se baseou em uma ideia difundida na historiografia joânica do período que tem raízes no século XVIII.

\subsection{1 - A origem iluminista da discussão sobre o entusiasmo}

Ao analisar a forma como Joana d'Arc é apresentada pelos escritores do século iluminista, Jeroom Vercruysse percebe a constância do tema do entusiasmo e da persuasão interior que apareceu como uma explicação racional alternativa à crença na inspiração divina de Joana. De fato, a necessidade de se posicionar em torno do tema das vozes de São Miguel, Santa Margarida e Santa Catarina, às quais Joana se referia como uma presença constante em sua vida desde os 13 anos de idade, era sentida pelos autores do século das Luzes. Nem todos se contentavam em simplesmente desconsiderar e ironizar esse tema por completo, como o fez Voltaire, e para tanto buscaram uma via inteligível que pudesse explicar o fato de Joana insistir que ouvia tais vozes sem que isso concorresse para configurá-la como impostora ou significasse uma aceitação da intervenção sobrenatural naquele episódio da história francesa.

${ }^{168}$ MICHELET, J. Joana d'Arc. p. 55. 
Uma das argumentações mais pungentes a esse respeito partiu do abade, teólogo e doutor da Sorbonne, Nicolas Lenglet Dufresnoy:

"Acreditar que essa moça teve visões, aparições, revelações de santos e de santas (...) eu não acredito. (...) Mas essas aparições eu substituo por uma persuasão interior, uma meditação refletida que sacode, que anima, que agita fortemente a imaginação; e são os esforços dessa última faculdade que freqüentemente nos apresentam como reais objetos que nada são além de simples imagens que nós formamos em nós mesmos." 169

Sua introdução à vida de Joana nos esclarece sobre a importância do tema no XVIII - muitos heróis são afetados pelo entusiasmo. Ele dá assim uma explicação sobre o heroísmo em geral, não apenas o de Joana: "O que eu chamo aqui de persuasão ou esforço da imaginação, pode-se qualificar com um título mais honorável, o de heroísmo ou entusiasmo, pois ambos nos levam à grandeza e ao sublime em ações louváveis e virtuosas." 170

É possível verificar posteriormente como os autores vão de forma intercambiante apresentar o entusiasmo identificado ou não com a auto-sugestão ou por vezes admitindo que a Providência poderia atuar através de indivíduos com prédisposição a esse entusiasmo. Dessa forma é que Lenglet Dufresnoy via a possibilidade disso acontecer aos heróis. Muitas vezes se procurou uma origem psicológica para o fenômeno, como o fez Claude Villaret em sua Histoire de France de 1765, o que não excluiu a continuidade do tema da Providência divina associada a esse entusiasmo como se apresenta em Dufresnoy.

\footnotetext{
${ }^{169}$ DUFRESNOY, N. L. Histoire de Jeanne d'Arc, dite la Pucelle d'Orleans, vierge, hérö̈ne et martyre d'état: suscitée par la providence pour rétablir la monarchie française, Paris: Coutellier, 1753-1754. p. IX-X. Tradução nossa.

${ }^{170}$ Idem, p. XV.
} 
Em La France sous les cinque premiers Valois, de 1787, Pierre Charles

Levesque explica dessa forma o sucesso das ações de Joana:

"jovem entusiasta que mais contribuiu para restabelecer a fortuna do Estado, passando aos espíritos as ilusões as quais assaltavam sua alma... Como ela não sofria das enfermidades periódicas de seu sexo, seu sangue se mantinha com abundância em seu cérebro e lhe causava um tipo de loucura que levou à salvação de seu Estado."171

Vemos que mais uma questão debatida no século XIX - a ausência do ciclo menstrual - foi suscitada no século XVIII relacionada à questão do entusiasmo. Em Lebrun des Charmettes esse tema é também retomado para explicar o sucesso de Joana em seus empreendimentos. Nesse caso o âmbito privado se manifesta no público, de acordo com os ditames biográficos de Plutarco seguido por Lebrun des Charmettes. Também Michelet, ao ver Joana como uma criança, busca nessa mesma argumentação do século XVIII a explicação sobre o poder de criação de Joana d'Arc que faz dela a encarnação da França.

Em terras inglesas o tema do entusiasmo de Joana d'Arc também teve impacto. No prefácio de seu poema épico Joan of Arc de 1795 Robert Southley esclarece:

"Que ela se acreditava inspirada, poucos vão negar; que ela era de fato inspirada ninguém vai se aventurar a afirmar. (...) Entusiasmo, e não de qualquer tipo, era necessário para permitir a uma jovem donzela assumir a profissão das armas, lutar entre os demais e submeter com uma força inferior um inimigo até então tido como invencível." 172

\footnotetext{
${ }^{171}$ LEVESQUE, P. op. cit. apud VERCRUYSSE, J. op. cit. p. 1687. Tradução nossa.

${ }^{172}$ SOUTHEY, R. Joan of Arc. An epic poem. Longman: Londres, 1812. P. VII-VIII. Existem ainda outros autores como William Guthrie que em A general history of England desenvolve esse tema vendo em Joana "Nada além de entusiasmo, que é uma sincera, calorosa e desinteressada operação da mente.”apud VERCRUYSSE, op. cit. p. 1688. Tradução nossa.
} 
Mas o autor inglês mais influente para os autores do século XIX francês foi sem dúvida David Hume, cuja obra foi usada como fonte de informações para a história de Joana d'Arc por muitos autores que o citam de forma insistente. Em The History of England de 1762 ele também identifica o entusiasmo gerado pela auto-sugestão na trajetória de Joana:

"ela imaginava que tinha visões e ouvia vozes que a exortavam a restabelecer o trono da França e expulsar os invasores estrangeiros. Uma coragem incomum em seu temperamento fez com que ela se esquecesse de todos os perigos que poderia enfrentar em tal caminho e, acreditando estar destinada pelos céus a realizar esse trabalho, deixou de lado o pudor e a timidez característicos de seu sexo, sua idade e sua baixa condição social." 173

Em Hume, esse entusiasmo fez com que ela ultrapassasse todas as barreiras sociais às quais estava submetida. É a capacidade do entusiasmo de levar o herói a subverter a ordem, tema que aparece no século XIX na historiografia francesa, porém, como vimos, associado à nova atribuição que o herói passa a receber na medida em que se relaciona ao ideal da coletividade.

" e todos os sentimentos de amor e cavalaria foram unidos ao do entusiasmo para inflamar o gosto do povo pela fantasia com propensões a seu favor [de Joana]" Para Hume a fantasia em torno de Joana foi alimentada pelo rei e pela nobreza contra o inimigo. Depois dos acontecimentos em Orléans todos estavam convencidos da missão divina de Joana: “Após esse sucesso nada parecia impossível para a Donzela e seus entusiásticos companheiros."

\footnotetext{
${ }^{173}$ HUME, D. op. cit. p. 77. Tradução nossa.

${ }^{174}$ Idem, p. 125. Tradução nossa.
} 
Segundo Hume, Joana desejou voltar para casa depois da coroação de Charles VII, mas os nobres interessados nos efeitos que ela causava no exército pediram que ela continuasse as batalhas para expulsar os ingleses.

O tema do entusiasmo foi alvo das reflexões de David Hume em um escrito específico, parte de seus Ensaios morais, políticos e literários, elaborados entre 1742 e 1754. No décimo ensaio "Da superstição e do entusiasmo" o autor traça uma comparação entre essas duas formas de "falsa religião" concentrando-se em analisar os diferentes efeitos que elas causam na sociedade. "Fraqueza, medo, melancolia unidos à ignorância são as verdadeiras fontes da superstição. (...) Esperança, orgulho, presunção, imaginação fértil unidas à ignorância são as verdadeiras fontes do entusiasmo." 175

Preocupado, sobretudo em mensurar a importância da atuação dessas duas tendências da mente humana ao longo do processo revolucionário inglês, Hume se preocupa em definir que seitas ou grupos religiosos estavam sob a influência da superstição e quais eram regidas pelo entusiasmo. Ora, para Hume a superstição é perniciosa para a vida civil na medida em que coloca as pessoas sob o jugo do clero, já que o indivíduo se vê refém do medo causado pelas explicações sobrenaturais dos eventos e sente a necessidade de se colocar sob a proteção daquele que supostamente está em contato com o poder divino. Dessa forma o povo não se vê como agente do seu futuro e a vida social livre é cerceada pela dominação dos sacerdotes.

No caso do entusiasmo, uma vez que nasce da presunção, vinda do sucesso, gera uma auto-confiança a ponto de a pessoa se ver como escolhida de Deus. Dessa forma os grupos regidos pelo entusiasmo não veem a necessidade de intermediários no contato

${ }^{175}$ HUME, David. Essays Moral, Political, and Literary (1742-1754) ESSAY X: OF SUPERSTITION AND ENTHUSIASM. On line: http://www.english.upenn.edu/ mgamer/Etexts/hume.superstition.html acesso em março de 2011. p. 1. Tradução nossa. 
com o Ser Supremo e dessa forma não está sob o comando de um grupo de sacerdotes que poderiam definir seu destino. O entusiasmo dessa forma levaria à liberdade civil, pois gera a revolta contra a tirania do autoritarismo político.

"Como o entusiasmo vem do orgulho presunçoso e da confiança, a pessoa se julga suficientemente qualificada para se aproximar da Divindade sem nenhum mediador humano. ${ }^{, 176}$ Dessa forma o entusiasmo atua para destruir o poder eclesiástico. A superstição faz o homem temeroso e submisso, tornando o clero tirano e perturbador da sociedade, enquanto o entusiasmo é naturalmente acompanhado do espírito de liberdade.

As raízes dessa discussão, contudo, são ainda mais profundas do que aparentam, tocando o próprio âmago das preocupações dos iluministas na Inglaterra do século XVIII. Como lembra Pocock, nesse país, em particular, travou-se entre os intelectuais um longo debate sobre o entusiasmo vindo das reflexões do período que eram parte do ramo do Iluminismo que se manifestou na Inglaterra: o Iluminismo Protestante.

"muito do que chamamos Iluminismo na Inglaterra, como Margaret Jacob efetivamente demonstrou, foi uma estratégia clerical para manter uma via media, e o panteísmo iluminista que ela chama de Iluminismo Radical foi parte do que foi atacado com o nome de spinozismo e entusiasmo."177

O Iluminismo Protestante continha de forma potencial em seu pensamento a descrença a partir da qual se buscava uma explicação histórica para o surgimento da superstição e do entusiasmo: ambos foram produtos da substituição da teogonia pela religião natural. "A superstição de muitos era manipulada pela sabedoria de poucos que

\footnotetext{
${ }^{176}$ HUME, David. op. cit. P. 2. Tradução nossa.

177 POCOCK, J. G. A. Edward Gibbon in History: Aspects of the Text in The History of the Decline and Fall of the Roman Empire. THE TANNER LECTURES ON HUMAN VALUES. Delivered at Yale University March 1-3, 1989. p. 344. Tradução nossa.
} 
vieram no papel de sacerdotes." 178 Aqueles que se reuniam para venerar o princípio essencial de cada um aparecem no papel de entusiastas.

Para a Igreja Anglicana, a doutrina da transubstanciação seria a última superstição. Ao mesmo tempo, os anglicanos querem se defender contra as seitas radicais.

"A Igreja Restaurada então colocou de um lado a superstição e o sacerdócio e de outro o entusiasmo e o fanatismo; por entusiasmo, significando primeiro a falsa atribuição à inspiração pessoal ou congregacional, e em segundo lugar o erro psicopatológico de tomar as ideias ou fantasias sobre Deus pela ação ou presença de Deus na mente."

O que muda com a interpretação de Hume é que há a possibilidade de uma visão mais positiva acerca do entusiasmo, ele rompe, de certa forma, com os meios eclesiásticos e clericais nos quais essa visão foi formada. Em Hume a religião está ligada à natureza. A superstição torna possível a ordem civil em que seres humanos podem ser governados e o consentem. Já no entusiasmo, a mente venera a si própria. Hume desloca a superstição e o entusiasmo da relação com a História da Religião e caracteriza-os como atividades próprias da mente humana.

Quando Pocock analisa a importante discussão a respeito do entusiasmo no século XVIII, que teve papel fundamental na construção dos argumentos de Gibbon em Declínio e queda do Império Romano, ele enumera todas as contradições presentes nessa discussão. O autor lembra ainda a importância do ambiente intelectual pós Revolução Francesa para a ressignificação dessa ideia:

\footnotetext{
${ }^{178}$ Idem, p. P. 348. Tradução nossa.

${ }^{179}$ Idem. p. 342. Tradução nossa.
} 
"Tentei mostrar que o Iluminismo a partir do qual Declínio e Queda toma forma, era conservador, em seu início, no sentido de que foi direcionado não apenas contra a ortodoxia e a tradição eclesiástica, mas contra o Iluminismo e a espiritualidade populista ao mesmo tempo; e uma vez que o entusiasmo que foi denunciado como racionalista e ao mesmo tempo místico, materialista e ao mesmo tempo espiritual, a denúncia estava bem colocada para continuar, na era da revolução e redefinir entusiasmo, como Burke fez, como energia direcionada contra tudo o que dá sentido à sociedade. Os volumes conclusivos de Declínio e Queda apareceram em maio de 1788 no último momento possível antes da grande transmutação da crítica eclesiástica e filosófica ao entusiasmo, em crítica conservadora e liberal daquilo que um estudioso moderno chamou de 'fogo que ataca as mentes dos homens.",180

A partir dessa linha de raciocínio o entusiasmo popular era visto como insanidade, porém, como afirma Pocock, a interpretação acerca da influência do entusiasmo oscilava, pois enquanto muitos viam nesse fenômeno um excesso destrutivo, outros vão interpretá-lo como fundamental na busca pela liberdade. O que nos importa nessa discussão é compreender o quanto ela foi fundamental para que no século XIX a relação entre Joana e o povo, e/ou o Terceiro Estado, ficasse bem sedimentada nos textos dos historiadores franceses.

A palavra entusiasmo tem origem grega: en + theos, literalmente, 'em Deus', “possuído por Deus”. As várias referências ao entusiasmo mostram que, de fato, foi um tema discutido por muitos. Mas, de acordo com Claire Oliveira, ${ }^{181}$ ainda que o sentido primeiro do termo seja o de inspiração divina ele foi sofrendo alterações semânticas ao longo do tempo. Estando presente em Platão e posteriormente em Plotino, chega a Giordano Bruno para quem o entusiasmo significava o eroico furore que nada tinha a

\footnotetext{
${ }^{180}$ Idem, p. 361. Tradução nossa.

181 OLIVEIRA, Claire C. "Ser sóbrio e racional: os usos ambíguos da razão na literatura dietética dos primórdios das luzes inglesas". In: Scientiae Studia.. vol.4 no.1 São Paulo Jan./Mar. 2006. Disponível em: http://www.scielo.br/scielo.php?pid=S1678-31662006000100004\&script=sci_arttext.

Acesso:
} 23/10/2011. 
ver com influências divinas. Bruno entendia que o entusiasmo poderia levar o homem a desvendar os mistérios do universo. Posteriormente essa se torna uma questão central para o Iluminismo, como vimos.

Mesmo na literatura inglesa do século XIX o tema é recorrente e a presença do entusiasmo nos artistas é entendida em termos de uma estética discursiva. A "Poética do entusiasmo", vinda de um grande senso de liberdade, significava a completa absorção no divino, garantia de uma suprema liberdade de criação que levava ao âmago do sentido e significado de todas as coisas ${ }^{182}$.

No contexto iluminista, como vimos, o tema torna-se alvo de debates. Porém, como afirma Pocock, não houve um Iluminismo, mas "iluminismos", já que muitas vezes as discussões tiveram origens diversas com desdobramentos também diferentes. Para esse autor, o ceticismo de Gibbon ligava-se ao que ele chama de "Iluminismo Protestante". Voltando nosso olhar para o ambiente intelectual francês do mesmo período, essa mesma característica peculiar de Joana, sua insistência na audição das vozes e a certeza na inspiração divina gerou duras críticas, sendo a mais famosa a de Voltaire que em La Pucelle e no verbete "Joana d'Arc" no Dicionário Filosófico ${ }^{183}$, minimiza a importância de todas as ações de Joana e desqualifica a sua personalidade em nome também de um princípio racional, o que fez com que o fenômeno vivido por Joana não merecesse nem mesmo uma denominação diferente de crendice ou idiotice. Mas a reivindicação de uma relação direta com o divino e o sucesso nas ações que daí se origina, denominado de entusiasmo, tem uma interpretação muito diferente dentro das discussões do Iluminismo inglês. No caso de Joana, em particular, a influência de

\footnotetext{
${ }^{182}$ MEE, J. "Blake and the poetics of enthusiasm". In: MEE, J \& Keymer, orgs. The Cambridge companion to english literature: 1740-1830. Cambridge University Press, 2004. pp. 194-210.

${ }^{183}$ Ver nota 24, capítulo 1.
} 
Hume é definitiva, pois ele oferece uma interpretação que permitia associar o fenômeno a um tema caro ao período: a liberdade civil.

A nova visão sobre Joana d'Arc no século XIX, nesse aspecto, é tributária do Iluminismo Protestante e de sua influência entre os franceses. Não se optou pela interpretação voltairiana, que uma vez adotada, descartaria Joana d'Arc como uma heroína. Bem ao contrário, para Voltaire ela era apenas uma representante do fanatismo e ignorância em que viviam o povo francês do século XV. Prova disso foi sua ingenuidade ao lutar por um rei mesquinho e ingrato, ingenuidade que lhe custou a própria vida. Dessa forma os sentimentos que Voltaire demonstrava por Joana iam da compaixão ao desprezo, os mesmos que nutria pela Idade Média, período em que o obscurantismo impedia as pessoas de verem a verdade. Muito mais diversificada, como vimos, foi a via interpretativa para o mesmo fenômeno entre os intelectuais ingleses desse período.

Seria possível relacionar o entusiasmo de Joana à coragem (andreia), virtude típica dos herois da Antiguidade, de acordo com seus biógrafos? A questão é que o entusiasmo não é um atributo moral como a coragem, apesar dela ser o seu pressuposto. Como vemos nas discussões do século XVIII, o entusiasmo era visto como uma prédisposição da alma a partir da qual nem sempre as ações tinham resultados benéficos, segundo alguns autores. Quando, porém, há a descrição das batalhas, como a campanha de Orléans, o entusiasmo que guia Joana e seu exército ganha ares da andreia que movimentava Péricles e seus guerreiros, segundo Plutarco. A partir dessa coragem heroica ${ }^{184}$, tal como aparece no gênero biográfico, a importância da estratégia cede lugar

\footnotetext{
${ }^{184}$ Frazier não deixa de considerar a ambiguidade com a qual a virtude da coragem aparece nas Vidas Paralelas. Andreia é tanto a coragem propriamente guerreira no contexto militar (que nesse caso aparece sempre balanceada pela virtude da prudência) quanto a "força da alma" para enfrentar adversidades e
} 
à identificação da presença de andreia, atributo moral fundamental dos grandes líderes políticos-militares. Da forma como são descritas as batalhas lideradas por Joana d'Arc é inegável a recorrência a mais essa tópica retórica, o que não significa que ela tenha encoberto as nuances de significado que percebemos na discussão acerca do entusiasmo. Dizendo de outra forma: a presença de um topos típico do gênero biográfico não impediu que as obras sobre Joana d'Arc abordassem o tema do entusiasmo em consonância com os debates do período.

Como vimos, tanto em Michelet quanto nos outros autores, a vida de Joana d'Arc e a história da França se mesclam em uma unidade tal que não nos permite separar tais obras em gêneros textuais distintos: ao mesmo tempo em que há elementos do gênero biográfico,

Ao associar o entusiasmo à liberdade civil David Hume, referência fundamental para os historiadores franceses escreverem sobre Joana d'Arc, abre caminho para a interpretação de Joana como defensora das liberdades políticas, imagem cristalizada nos escritores liberais do século XIX. Na verdade, seu contemporêaneo Lenglet Dufresnoy, demonstrando sua conexão com os debates políticos de seu tempo, estabelece no prefácio de sua biografia de Joana d'Arc uma diferenciação entre o entusiasmo e o fanatismo, exaltando o primeiro exatamente por levar a resultados virtuosos.

No século XIX o tema foi ressignificado pelos historiadores franceses na dialética individualidade/coletividade, particular/geral relacionando Joana com o povo, o que pode ser visto nas obras de Michelet e Sismondi. Em Lebrun des Charmettes e

dominar as paixões. Essa nuance, porém, não anula sua presença angular como uma das quatro virtudes cardeais dos herois de Plutarco. FRAZIER, F. op. cit. 
Berriat Saint-Prix o entusiasmo também explica as ações de Joana movimentando-a através do laço que a ligava com a França, que se manifestava na sua devoção ao rei.

Para a maioria dos autores da primeira metade do século XIX o que fez com que Joana tivesse sucesso foi sem dúvida o entusiasmo. Porém eles vão encontrar uma explicação para a aceitação de Joana interpretando seu contexto histórico como obscuro e propenso à interpretação de todos os fenômenos como sobrenaturais. Os contemporâneos de Joana a aceitavam, mas não sabiam o que de fato estava acontecendo devido ao obscurantismo da época. Sismondi, como vimos, atribui ao clima de superstição generalizado a visão deturpada de que Joana d'Arc era encarregada de uma missão divina. Além disso, esse contexto supersticioso explicaria vários outros acontecimentos como o julgamento injusto, bem como o abandono de Joana pelo rei.

L'Averdy, no momento em que defende Carlos VII das acusações de ter abandonado Joana d'Arc, encontra nesse argumento a explicação: “Oh! Como calcular os efeitos funestos que poderiam resultar contra ele nesse tempo de profunda ignorância, em que a França e a Inglaterra só poderiam ser habitadas por homens do século XV?"185

Já Lebrun des Charmettes atribui o julgamento de Joana à barbárie do século XV: “A história desse tempo de ignorância e de barbárie oferece numerosos exemplos do esquecimento da benevolência na conduta dessa multidão de eclesiásticos." ${ }^{186}$

Também em Michelet, o contexto em que Joana viveu aparece como os últimos suspiros de uma agonizante Idade Média em que já se podiam ver rastros de um sentimento nacional. "Na fogueira de Rouen terminava a Idade Média e começavam os

\footnotetext{
${ }^{185}$ Idem, p. 170. Tradução nossa.

${ }^{186}$ CHARMETTES, L. p. 107. Tradução nossa.
} 
tempos modernos." ${ }^{187}$ É por isso que para Michelet a originalidade de Joana não estava em suas visões: "Quem não as tinha na Idade Média?"188

Michelet e Quicherat disseram que Joana d'Arc foi a última santa da Idade Média e a primeira mártir de uma modernidade que rompe com tais misticismos e superstições. Aqueles que não entenderam Joana pensavam que faziam isso por motivos religiosos ou supersticiosos, mas para Michelet se tratava de uma resistência contra a modernidade. O fato de Paris fechar as portas para a Donzela significava que eles estavam contra o progresso, ou seja, contra a nação, contra a unidade.

Em Augustin Thierry a Guerra dos Cem Anos também encontra seu sentido na unidade da nação. Chamando esse movimento de revolução, ele se pergunta de onde vem o socorro que coloca os ingleses para fora da França. Ele diz que não nasce das tropas, mas de um fanatismo patriótico dos soldados pobres e das milícias das vilas. "O aspecto religioso é apenas uma forma: esse era o sinal mais energético da inspiração popular" ${ }^{189}$. Trata-se de um exemplo da ressignificação do entusiasmo ligado à ideia de misticismo que seria naquela época a única forma possível da manifestação popular.

É uma visão da Idade Média muito difundida no século XIX. Mas porque não dizer que o argumento da superstição e ignorância ainda é usado como chave interpretativa para muitos aspectos da sociedade medieval? Ao se buscar uma explicação pelo contexto, fala-se da ignorância e superstição daquele momento. No caso de Joana, a contextualização a partir do misticismo ajuda no argumento em favor do entusiasmo, que naquele período só poderia ser interpretado como intervenção divina, até mesmo por Joana d'Arc.

\footnotetext{
${ }^{187}$ MICHELET, J. Conferência na Sorbonne de 1834-35. In: Oeuvres complètes... p. 300. Tradução nossa.

${ }^{188}$ MICHELET, J. Jeanne d'Arc... p. 13. Tradução nossa.

189 THIERRY, A. Lettres... p. 33. Tradução nossa.
} 
A ressignificação do entusiasmo faz com que essa noção seja colocada na relação entre particular e geral, relacionado à ideia de povo. Ela racionaliza a interpretação e ao mesmo tempo permite que Joana seja ligada à questão nacional sem que o sobrenatural tenha peso decisivo. A utilização dessa ideia faz com que os autores se vejam no uso de sua racionalidade e objetividade e, na medida em que associam a crença das pessoas na ação de Joana como fruto da superstição da época, cria uma ideia de infância da nação francesa localizada no período medieval em que não se tinha consciência do nacional, muito embora já agissem intuitivamente em defesa dessa ideia. Como vimos, a discussão a respeito do entusiasmo não surgiu no século XIX, sendo importante para as interpretações racionalistas do período iluminista. Mas foi uma ideia fundamental para que o século XIX não descartasse Joana d'Arc como heroína nacional em um período no qual a história precisava ressignificar o passado e estabelecer referências identitárias com a criação de heróis.

A tradição iluminista serviu de referência teórica para a construção da imagem de Joana, contribuindo para definir o caráter laico desejado pelos oitocentistas. Nesse sentido a universalidade preconizada pelos ilustrados encontrou espaço entre os historiadores que, influenciados pelo Romantismo, enfatizaram a importância das ações individuais nos processos históricos. A epopeia de Joana servia ainda às discussões sobre o papel revolucionário do povo que estavam submetidas à mesma dupla influência, iluminista e à romântica. No século XVIII a ideia de entusiasmo dá caráter positivo a essa particularidade de Joana. Na verdade a inovação de Michelet consiste em levar essa característica de Joana às massas.

David Hume deu o tom dessas discussões até mesmo na controvérsia sobre a missão de Joana, a respeito da qual Sismondi se mostra herdeiro da opinião humeana 
para reforçar o papel do entusiasmo. Ao relacionar esse tipo de "temperamento arrojado" à liberdade civil, ele lança as bases para uma interpretação que relacionasse a Guerra dos Cem Anos como momento primordial da luta pela liberdade na França, como afirmam Sismondi e Michelet.

Qual a necessidade de se atribuir o entusiasmo a Joana? Vemos que o tema se relaciona à questão do povo e da nação a partir da ideia de heroísmo. Mas a importância em se definir quem é povo e saber como deve ser sua atuação, relaciona-se com a interpretação da ruptura real reivindicada pelos jacobinos.

Não podemos deixar de lembrar que esse processo de ressignificação da imagem de Joana d'Arc na primeira metade do século XIX tem aspectos conservadores. Nasce em um ambiente conservador, o da Restauração Monárquica, já com elementos de ressignificação uma vez que Lebrun des Charmettes associa a causa de Joana d'Arc à defesa da nação.

A partir da década de 1830 a historiografia não só está mais ativa, como também os historiadores vão ter postos privilegiados na administração da Monarquia de Julho. Há algo a se conservar, a História é o discurso que vai convencer a todos disso ${ }^{190}$. Esses historiadores são liberais, mas não radicais. Cabe lembrar que a maior parte deles, além de participarem do governo monarquista iniciado pela Revolução de 30, vai ver nesse acontecimento o aprofundamento e a consolidação dos ideais de 89 , mas futuramente interpretarão a Revolução de 1848, mais radical e desejosa de rupturas, como um excesso desnecessário. Tal problemática é central para a definição de quem e o que é o povo, qual seu papel e o limite de sua atuação.

${ }^{190}$ Cf. discussão no capítulo 1. 
A historiografia percebe que há uma parte da conservação possível através de Joana d'Arc. Relacioná-la à nação foi um trabalho da Restauração. Mas a defesa da monarquia absolutista sai do argumento dos historiadores liberais, que mantêm a defesa da nação. Como isso estava presente na obra de Sismondi, ele será lembrado e valorizado pela geração de 1830, mas os outros autores como Saint-Prix e Charmettes serão criticados como parciais e sem método nesse ambiente em que se quer criar uma História Científica. No entanto, vimos que são importantes por tratar aquele momento como fundador de uma história nacional. Joana é heroína não por sua santidade, mas por reconhecer o legítimo governante e lutar por ele. Nos autores denominados como liberais, como Sismondi e Michelet, a ideia central vem da mesma origem dos autores da Restauração: uma Joana dessacralizada, movida pelo entusiasmo, uma heroína contextualizada e, sobretudo explicável e apreensível do ponto de vista nacional. A posição política dos autores se faz sentir no momento em que se posicionam diante da atitude de Carlos VII e no momento em que relacionam Joana ao povo, o qual no caso dos monarquistas só age com violência e revolta quando há um quadro de perda de autoridade da monarquia. Já em Michelet e Sismondi, quando abordam o tema do entusiasmo de Joana, querem exaltar o potencial revolucionário do povo, o verdadeiro soberano e fonte do poder que tem o legítimo direito de agir quando vê o país tomando um rumo indesejável.

Se no século XVIII há uma preocupação em explicar apenas racionalmente a atitude singular de Joana d'Arc, o século XIX parte dessa explicação para dar um novo significado às suas ações, que passam a ser relacionadas à defesa da nação, ao heroísmo popular e à sua capacidade de definir os rumos da história das sociedades. Tal reflexão leva-nos a reforçar o cuidado em relação a análises que tendem a interpretar o século 
XIX como um todo, e sua historiografia em particular, como um momento de total originalidade e ruptura, pois foram os homens oitocentistas que se esforçam em construir essa imagem para eles mesmos.

No século XVIII o entusiasmo foi uma alternativa à tese do sobrenatural e pôde dar um ar racional à história de Joana d'Arc. Na verdade contribuiu para minimizar ou mesmo anular as interpretações religiosas a respeito da Donzela. O apelo a uma interpretação racional do entusiasmo relaciona-se a uma tentativa de minimizar a importância da relação com o sobrenatural para os homens do XVIII o que, conforme análise de Claire Oliveira, seria o artifício da Razão como forma de controle social:

"Michael Heyd mostra que a escolha de uma explicação natural, médica (pela melancolia), do entusiasmo, ao invés das explicações sobrenaturais e demonológicas, obedece a uma vontade de reduzir ao silêncio os oponentes religiosos. O racionalismo anunciado por aqueles que criticam o entusiasmo mascara a sua vontade de controle das formas de dissidência religiosa (cf. Heyd, 1995, p. 1). Ser sóbrio e racional, para os defensores da ortodoxia anglicana, é conformar-se à doutrina estabelecida, é recusar qualquer divergência daquilo que é definido como norma em matéria de comportamento religioso. $\mathrm{O}$ apelo à razão, nos primórdios do Iluminismo inglês, é muito mais ambivalente do que parece à primeira vista e pode também ser compreendido como a manifestação de uma restrição social, pois "[...] a razão - mesmo após a época liberal - sempre simpatizou com o controle social" (Adorno \& Horkheimer, 1974, p. 30) que se exerce sobre os espíritos e também sobre os corpos." 191

Em nossa opinião a "racionalização" ou "laicização" da história de Joana d'Arc através da ressignificação do entusiasmo, a partir da qual ela foi associada definitivamente ao "povo francês", é o aspecto mais fundamental debatido pela historiografia joânica na primeira metade do século XIX. Ele explica em grande parte o

${ }^{191}$ OLIVEIRA, C. C. op. cit. p. 84. 
sucesso e a popularização definitiva de Joana d'Arc nas décadas seguintes. É curioso que o recente dicionário organizado por Philippe Contamine e Olivier Bouzy ${ }^{192}$ não possua a entrada "entusiasmo", conceito que não é discutido nem mesmo na primeira parte da obra que possui uma consistente discussão historiográfica. Nem ao menos no verbete "psiquiatria" o problema das vozes é associado ao entusiasmo. A referência vai direto ao século XIX trazendo apenas a informação de que, em 1845, o médico Louis-Florentin Calmeil escreveu um tratado chamado De la folie no qual dedicou um capítulo à teomania de Joana d'Arc. A partir de nossas pesquisas porém pudemos perceber que se trata de uma discussão muito anterior, mais ampla, tocando o próprio princípio iluminista do devotamento à razão, a qual é importante para compreender como o período medieval passou a ser interpretado pelos fundadores da Historia Moderna.

${ }^{192}$ BOUZY, Olivier, CONTAMINE, Philippe. \& HÉLARY, Xavier. Jeanne d'Arc: Histoire et dictionnaire. Bouquins, 2012. 
"De repente um chiqueiro envolto num redemoinho de névoa virou uma fonte de fascínio inesgotável." Graham Robb

\section{CAPÍTULO III - Os elementos da ressignificação: o povo e a nação}

Nesse capítulo, analisaremos de que forma o contexto intelectual da primeira metade do século XIX esteve marcado pela influência dos conceitos de povo e nação. Tais noções foram fundamentais para o processo de ressignificação de Joana d'Arc, uma vez que a Donzela foi definida pela historiografia do período como legítima representante do povo e ícone da união nacional.

\section{1 - Temas centrais de uma historiografia "liberal" e "romântica"}

“O povo é como Deus, está em toda parte e em arte alguma... Não é nas histórias de Thiers, nos discursos de Guizot, nas frases de nossos retóricos. Advinhamo-lo em Hugo e Lamartine, sentimolo em Chateaubriand. Vemo-lo no último livro de Michelet, esplendidamente intitulado $O$ povo. Não é um bom livro que se deve ler, é uma boa ação que é preciso sentir para compreendêla."

Charivari, resenhando O povo em 1846

Inúmeros nomes do século XIX, oriundos dos mais diversos nichos da sociedade francesa, referiram-se e valeram-se do termo "povo", sem se preocupar necessariamente em defini-lo com precisão. Mas ao contrário, por vezes se aproveitavam exatamente da generalidade que o encerra para fazer com o que o vocábulo contribuísse na argumentação de suas ideias. A partir disso, diferentes correntes políticas, econômicas, sociais e mesmo religiosas imprimiram ao termo seu tom particular, fazendo dele um dos pilares da ressignificação do passado realizado pela sociedade francesa oitocentista, 
pois não raro essas diferentes correntes e tendências projetaram para os séculos anteriores a entidade "povo" conferindo-lhe o significado que lhes era mais conveniente à medida que a historicizavam.

Concomitantemente à popularização desse termo, houve outros tão empregados quanto, tais como "massas", "multidão" e "nação" que, de acordo com muitos pesquisadores $^{193}$, fizeram sua fortuna graças ao Romantismo, pois estariam dentro desse "movimento", relacionados à ideia de processo, ação e constituição/construção da sociedade ao longo do tempo. Guinsburg, por exemplo, relaciona ao Romantismo vários conceitos que marcaram as discussões políticas do século XIX: nação, povo, massa, opinião pública, classe e outros agentes históricos, culturais, políticos, sociológicos, econômicos e ideológicos que passam a ser vistos como fonte dos processos, dos dinamismos, dos movimentos e das vontades coletivas. Tal premissa fez com que a historiografia da primeira metade do século XIX, especialmente após a Restauração, fosse denominada de "romântica". Ao entrarmos em contato com obras e autores que propõem essa expressão comprovamos que a raiz da explicação é sempre a mesma: a ruptura trazida pela Revolução Francesa modificou a relação com o passado, provocando uma nova sensibilidade expressa no movimento romântico.

Antes de nos aprofundarmos um pouco mais nessa discussão, vale voltar ao ponto central de nossa investigação, uma vez que se trata do processo idêntico verificado na construção de Joana d'Arc como heroína nacional da França. Na maioria das vezes ela é caracterizada como heroína "tipicamente romântica", expressão que denota toda a dependência do processo de sua popularização com o movimento

\footnotetext{
${ }^{193}$ Alguns exemplos: CROSSLEY, C. op. cit. GINSBURG, J. "Romantismo, historicismo e história". In: O Romantismo (org.) São Paulo: Perspectiva, 2005 e NUNES, B. "A visão romântica". In: GUINSBURG, J. op, cit.
} 
romântico. Ao mesmo tempo, definir Joana d'Arc como ícone da "historiografia romântica" aponta para a mesma ideia de dependência, o que nos leva a testar a validade do termo para a análise do processo que mais nos interessa nesse trabalho. Além disso, a profunda identificação de Joana d'Arc com os termos "povo", "pátria" e "nação", como pudemos verificar nas fontes ${ }^{194}$, caros ao movimento romântico, nos leva à mesma direção investigativa para que seja avaliado de que forma a ideia de ressignificação pode contribuir para a compreensão dessa identificação.

Tomemos, a princípio, a distinção proposta por Benedito Nunes, para quem o "Romantismo" pode ser compreendido em função de duas categorias:

1 - uma psicológica, refletindo um modo de sensibilidade que se expressa no amor pela irresolução e pela ambivalência que separa e une estados opostos. Referirse, portanto a um "estado psicológico romântico", significa reconhecer nele um caráter conflitivo, interiorizado, uma inquietude e insatisfação permanentes diante de situações-limite.

2 - e outra histórica que caracteriza um movimento literário e artístico datado de fins do século XVIII até o final da primeira metade do século XIX. Trata-se, assim, do movimento de ruptura com os padrões estéticos do classicismo, significando uma nova atitude em relação à literatura, um estado da poesia.

Ao contrário da tendência psicológica romântica, o contexto clássico e iluminista era avesso à "afirmação da originalidade pessoal e ao entusiasmo, estados espiritualmente afins." 195 Na visão iluminista haveria uma comunicação, uma correspondência entre o mundo exterior, da natureza, regido por leis gerais universais e

${ }^{194}$ Conf. discussão do capítulo 2.

${ }^{195}$ NUNES, B. “A visão romântica”. In. GUINSBURG, J. O Romantismo. São Paulo: Perspectiva, 2005, p. 57. 
racionalmente explicáveis e o mundo interno do ser humano que, da mesma forma, deveria buscar orientar-se segundo essas leis gerais.

Outra diferença entre o pensamento iluminista e o romântico, ainda de acordo com as definições de Nunes seria a forma de lidar com a relação entre o indivíduo e o todo social em que ele se insere:

"Ao cosmopolitismo abstrato do século XVIII, supressor das diferenças nacionais, o Romantismo opôs um nacionalismo completo, que foi preparado pela concepção herderiana da 'unidade orgânica de cada personalidade com a forma de vida que lhe corresponde ${ }^{196}$ : unidade expressiva quando florescente, dando-se a manifestar em tudo o que o homem faz. 'Num certo sentido, ' diz Herder, 'toda perfeição humana é nacional, secular, e estritamente considerada, individual'. "197

Dessa forma, Nunes argumenta em favor da hipótese de que o Romantismo seria um dos sustentáculos da ideia de nação por propor uma nova forma de pertencimento ao todo, que se baseava em características comuns compartilhadas por pessoas de determinado grupo, formado supostamente em um passado distante.

$\mathrm{Na}$ análise proposta por Guinsburg, o pensamento histórico gestado ao longo do século XIX é ainda mais tributário do Romantismo. Segundo esse autor, apesar da fluidez do termo, ele guarda profunda relação com a consciência histórica. Em que pese a existência de vários "romantismos" e vários "românticos" algo existe em comum: “(...) é um fato histórico que assinala, na história da consciência humana, a relevância

\footnotetext{
${ }^{196}$ BERLIN, Isaiah. Herder, Eco. Buchholz-Bogota. Dez. 1965.

${ }^{197}$ NUNES, B. "A visão romântica". In: GUINSBURG, op. cit. P. 59. HERDER, Filosofia de La historia para la educación de la humanidad. Ed. Nova, p. 55.
} 
da consciência histórica. É uma forma de pensar que pensou e se pensou historicamente." 198

Mais uma vez a explicação do que foi o Romantismo passa pela oposição ao pensamento iluminista. Com Montesquieu e Rousseau as normas e instituições eram vistas como produto de contratos entre os seres humanos. A história era vista como material para se narrar a vida dos homens ilustres, e não como uma área do conhecimento disposta a analisar processos ao longo do tempo, podendo assim contribuir para a compreensão da sociedade.

O Romantismo teria aprofundado a trilha aberta por Vico, a partir de quem o discurso histórico sofre uma mudança revolucionária: deixa de ser apenas descritivo e se

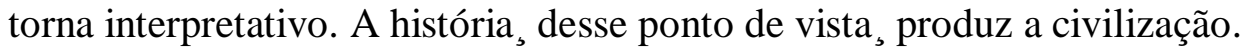

Trabalhando a partir dessa ideia, o Romantismo aglutina as sociedades em mundos, comunidades, raças. Há características peculiares, mas que, na verdade, refletem o grupo. Daí vem a ideia de um povo alemão, uma raça nórdica, etc, sendo as características, ao mesmo tempo, individuais e coletivas. A História passa a integrar o estudo do desenvolvimento dos povos e a cronologia dá significado às suas ocorrências; popularizam-se termos e expressões como povo, gênio do Cristianismo, Restauração, Contrarreforma, etc. “(...) talvez não seja exagero dizer que com o Romantismo e sua revolução historicista se enceta a era propriamente historiocêntrica da História"199

A proposição de uma relação quase simbiótica entre História e Romantismo, a favor da qual esses autores argumentam, tem seu ápice quando entramos em contato com os termos historiografia romântica e historiadores românticos. Façamos uma

\footnotetext{
${ }^{198}$ GUINSBURG, op. cit. p. 14.

${ }^{199}$ GINSBURG, op. cit. p 18.
} 
breve avaliação do significado desses termos e de como se pode defender sua validade a partir das considerações de Ceri Crossley ${ }^{200}$.

Para definir com maior precisão o objeto de sua investigação, o autor remonta ao século XVIII quando o pensamento político liberal clássico formulou os ditames da compreensão da sociedade e do indivíduo em sintonia com as discussões iluministas.

A corrente liberal clássica via os indivíduos isoladamente, como auto-suficientes sendo conduta humana explicada em termos de vontades individuais. As ações individuais, contudo, poderiam contribuir para a prosperidade geral e o progresso material. Essa tendência teria sofrido um grande abalo com a Revolução Francesa em 1789, momento que redefiniu a identidade coletiva como nação.

Crossley defende a ideia da Revolução Francesa como evento fundador de uma nova forma de se pensar a organização social e a ação individual em relação à coletividade. Assim, a Revolução, além de redefinir a identidade a coletiva, teria mostrado a importância da ação do povo para a mudança.

Entretanto, o surgimento de intelectuais preocupados em avaliar os processos históricos para uma maior compreensão da sociedade, não teria surgido de forma abrupta. Um período de transição teria sido operado pelo grupo de pensadores conhecidos como "Ideólogos." Defensores de um republicanismo moderado, esse grupo era formado por intelectuais, filósofos e cientistas como, por exemplo, Destutt de Tracy, Volney, Daunou, Garat, Gingené, Cabanis, Bichat e Broussais.“(...) eles representam uma forma de liberalismo que não possui foco no apelo à História." ${ }^{201}$ Os ideólogos não

\footnotetext{
${ }^{200}$ CROSSLEY, op. cit.

201 Idem, p. 12. Os ideólogos exerceram influência direta no governo, especialmente na reforma educacional, e suas ideias eram divulgadas pelo seu influente jornal La décade philosophique (17941807). Foram homens que sofreram durante e o período do terror: Daunou, Volney e Destutt de Tracy
} 
buscam referência na História para suas explicações. A garantia de direitos, liberdades e responsabilidades ocorreria na medida em que a sociedade se orientasse pela razão.

Após certa hegemonia dos Ideólogos os rumos do pensamento liberal se modificam e seu conteúdo passa a ter outra relação com a história, diferente da setecentista. Os liberais do século XIX propuseram uma substantiva revisão do liberalismo do século XVIII, uma revisão que evita o materialismo científico e em geral rejeita as teorias contratuais, valorizando a interioridade e a história. O pensamento liberal pós-revolucionário vai se diferenciar do liberalismo do XVIII por valorizar a consciência individual como importante para a construção do indivíduo e não apenas a influência do seu entorno, do que lhe é externo. "Essa preponderância da consciência como agente ativo, espiritualístico torna-se o fundamento filosófico do liberalismo político pós-revolucionário.”202

Nesse ponto da argumentação, Crossley busca reforçar sua hipótese de aproximação entre o pensamento liberal e o Romantismo apostando na convergência de ambos no que se refere a certas posições clássicas do século XVIII:

"Madame de Staël criticou a epistemologia iluminista e reabilitou as noções de dever e auto-sacrifício, devotando um famoso capítulo ao 'entusiasmo' entendido como o interior do espírito do homem. Sob a influência de Kant e Jacobi ela inferia se os seres humanos, voltando-se para o interior e ouvindo a voz da consciência, poderiam ter acesso à verdade. A ideia de infinito poderia ser aproveitada pelo sentimento e pela imaginação, assim como pela razão."203

\footnotetext{
foram presos. "O movimento da Ideologia ao Liberalismo da Restauração - de Destutt de Tracy a Cousin - corresponde a uma mudança significativa na sensibilidade e na epistemologia. Para que o discurso sobre o passado se tornasse central para a definição do que constituíam as ciências humanas uma ruptura teve de ser operada com modos de pensamento Iluministas, com as representações setecentistas da relação mente e corpo, com a lei natural e com os princípios fundamentais da teoria do contrato social". Ibdem. Tradução nossa.

${ }^{202}$ CROSSLEY, op. cit. p. 22. Tradução nossa.

${ }^{203}$ Idem.
} 
Tratar-se-ia de um mesmo e grande movimento pós-revolucionário perceptível em vários âmbitos da sociedade francesa oitocentista, e que estabeleceu com o pensamento histórico do período uma relação especial.

"O novo liberalismo estava comprometido com a defesa do interesse individual da mesma forma que o liberalismo do século XVIII. No entanto, essa defesa agora estava apoiada por um senso de história como um processo intencional de tornar-se. $\mathrm{O}$ conhecimento do passado era de vital importância porque a história oferecia um grau de valor, uma fundação de significado. A Revolução transformou as expectativas das pessoas e relação a elas mesmas. Ao invés de definir o indivíduo como separado e isolado, o liberalismo pós-revolucionário buscava superar o senso de desconectude, representando o sujeito como embutido em uma rede de relacionamentos, como participante de um processo de desdobramento."204

Crossley também utiliza o termo "historiografia liberal" para se referir aos historiadores românticos que menciona, dentre os quais se encontram aqueles cujas obras forma analisadas em seu livro como Thierry, Guizot, Quinet e Michelet. Para o autor, a década de 20 do século XIX na França testemunha a consolidação da história liberal, sendo seus principais representantes Thierry e Guizot. Não se tratava de um modismo, mas de uma resposta aos eventos de 89 e ao período napoleônico. Nessa década, a história se tornou um componente necessário de toda reflexão séria sobre a sociedade francesa, já que as liberdades deveriam estar embasadas em fundações históricas.

O interesse romântico pelo passado foi integrado, na década de 20, pelo liberalismo. "Em vez do domínio do sujeito cartesiano, o si adquiriu uma dimensão coletiva e uma profundidade interior. ${ }^{205 "}$ As ações individuais são definidas pelo seu papel e seu papel era definido pelas pressões externas da mudança social. As histórias nacionais da década de 1830 apresentam a descrição de revanche, da vingança dos

\footnotetext{
${ }^{204}$ Idem, p. 24.

${ }^{205}$ Idem, p. 42.
} 
oprimidos sobre os opressores, a história da ascensão do terceiro estado e a vingança de 1789. Thierry, por exemplo, associava o liberalismo com a recriação imaginativa da realidade do passado, com o espetáculo das massas forçando a mudança e fazendo a história.

É como se o Romantismo e o valor da história para a compreensão do homem e da sociedade, se confundissem. A historiografia romântica teria sido aquela que deu suporte à identidade pós-revolucionária:

"Os efeitos desestabilizantes da revolução política foram sentidos por terem tido férteis consequências intelectuais, pois abriram uma nova perspectiva sobre o passado. A História tal como concebida pelo Iluminismo foi considerada inadequada. Ela não poderia prover o apoio à identidade pós-revolucionária que (...) desejava estar embebida em um novo tipo de comunidade, que mostrava novos modelos e propósitos. A dimensão histórica era algo que a nova geração considerava como essencial." 206

Para Crossley alguns pontos definem o historiador romântico: em primeiro lugar a oposição à ideia de que o passado é um conjunto de erros quanto mais aquele período esteve alheio à razão. Estaria presente a noção de processo, da necessidade da compreensão do homem ao longo do tempo para se chegar a uma leitura da sociedade no tempo presente. A partir da influência romântica, a sociedade teria passado a se compreender, a se auto-analisar e a agir em função de processos anteriores. A mudança tornou-se passível de ser compreendida e a História se torna a verdadeira ciência do homem. Por fim, temos um dos pontos mais importantes, a ideia de ação do povo, da nação, verdadeiras entidades coletivas que expressavam as paixões e os desejos do ser.

${ }^{206}$ Idem, p. 251. 
A presença do romantismo nessa historiografia seria também perceptível na tentativa dos autores em verificar de que modo as forças vitais podem ser invadidas pelas forças eternas culminado na unificação entre elas.

"O historicismo romântico acomodava essa diversidade vendo as eras $\mathrm{e}$ as civilizações como momentos de grande desdobramento, como fragmentos de um grande todo, como estágios da vida da humanidade valorizada como um ser coletivo. A história deixou de ser vista em uma limitada perspectiva dinástica cronológica. Os agentes da mudança histórica se tornaram forças impessoais, povos, raças, nações entidades coletivas definidas primeiramente de forma intelectual ao invés de termos biológicos.",207

Mas como definir esse aspecto como "romântico" se o próprio Hume, em meados do século XVIII, aponta para essa relação entre "forças vitais" e "forças externas" ao se referir ao entusiasmo como uma disposição de espírito capaz de levar à liberdade civil? As discussões de David Hume nos leva a questionar a suposta originalidade do Romantismo em relação à atuação coletiva, pois ele viu no entusiasmo do grupo dos puritanos uma oportunidade para a construção de uma sociedade livre.

Outra questão que nos incomoda nessa definição de historiografia romântica é a total dependência apontada entre o evento revolucionário e o pensamento romântico. A ideia da ação coletiva estaria presente no movimento romântico em outros países? Em que medida isso teria influenciado a intelectualidade francesa? A reflexão de Crossley, porém, não nos permite sanar tais inquietações. Em que pesem todos os acertos de sua interpretação, alguns pontos nos levam a questionar a denominação de "historiografia romântica”.

${ }^{207}$ Idem, p. 44. 


\section{2 - Romantismo: os limites do termo}

Toda a argumentação de Crossley está concentrada na mudança de sensibilidade em relação ao passado. Uma obra sintomática a esse respeito seria Génie du Christianisme na qual Chateaubriand opera uma mistura de catolicismo, monarquismo e roussianismo apontando para a direção seguida pela intelectualidade pós-revolucionária. No entanto, essa mudança de perspectiva não é bem explicada. Por que houve essa opção pelo romantismo? Apenas a busca por uma identidade após os eventos revolucionários explicaria essa mudança? Em relação à literatura o autor refere-se à existência de indivíduos angustiados, dissociados do todo, graças à revolução e à política moderna. Mas o que dizer sobre a influência do romantismo inglês e alemão e a forma como se difundiram e popularizaram na França?

Ao apontar para a existência de uma "consciência romântica" que se definiria pela busca da liberdade e sentimento de pertencimento, Crossley lança mão de mais um termo vago, em consonância com uma generalização feita do termo "romantismo", que ao mesmo tempo abarca tudo sem se referir a nada especificamente: "O que é Romantismo? Uma escola, uma tendência, uma forma, um fenômeno histórico, um estado de espírito? Provavelmente, tudo isso junto e cada item separado.”208

Em relação à conexão entre o Romantismo e os sentimentos trazidos pela Revolução Francesa, Crossley, como vimos, aposta na historiografia como um testemunho privilegiado para a expressão dessas relações. Essa "historiografia romântica" seria representada por Guizot, Thierry, Quinet e Michelet, pois todos

${ }^{208}$ GINSBURG, J. "Romantismo, historicismo e história”. In: O Romantismo (org.) São 
viveram 1789 vendo esse momento como um limite que marcava a emergência de novas formas de consciência e novos arranjos políticos. Em nosso entendimento trata-se do mesmo problema para o qual apontamos no Capítulo I dessa tese, já que a Revolução foi vista como evento fundador do mundo moderno em primeiro lugar por esses autores. A nosso ver são os próprios historiadores que se colocam nessa posição, como grandes testemunhas da aurora da humanidade, momento como nenhum outro capaz de exprimir a força da ação coletiva. Crossley parece ter se deixado seduzir por seus argumentos, pois ao longo do livro ele busca provar que tal tese, ou seja, que esses eventos produziram uma historiografia romântica, composta por historiadores que viveram aquele momento e por isso melhor poderiam expressar seus efeitos na nova relação com o passado estabelecida a partir de então. Finalmente Crossley une os dois termos ao afirmar que o Romantismo Liberal valorizava a individualidade inserida no drama da vida coletiva. Crossley, porém, não define o que significa o romantismo nessa expressão.

Se nos deixarmos guiar por essa definição, no entanto, os autores da Restauração como Lebrun des Charmettes e Berriat Saint-Prix não poderiam ser incluídos nessa nova visão sobre o passado e sobre a força da ação coletiva. Sua interpretação acerca do entusiasmo que movia Joana d'Arc, porém, nos mostra o contrário. Ambos os autores são monarquistas-absolutistas, e esse fato já é suficiente para mostrar os limites dessa expressão para a historiografia do período. Reduzir seus objetivos a um partidarismo político, conforme sustentamos ao longo desse trabalho, pouco nos ajudaria na compreensão da nova imagem criada para Joana d'Arc no século XIX.

Outro limite do emprego desses termos é que ele ignora a filiação intelectual à qual cada um desses autores sentia-se ligado e as próprias reservas que eles tinham em 
relação ao movimento romântico. Apesar de Viallaneix dizer que $O$ povo "pertence em sua totalidade à biblioteca romântica" ${ }^{209}$ o próprio Michelet critica a estética do romantismo. Não lhe agrada o que ele define como "gosto pelo feio", nem o fato de alguns românticos voltarem seus olhos para o excepcional, o bizarro, o violento, o fantástico quando vão se referir ao povo. Em sua opinião o Romantismo desqualificava o povo decretando sem maiores análises: "o povo é assim”.

Apesar de nos negarmos a utilizar os termos "historiografia romântica" ou "historiadores românticos", não podemos negar que há alguns temas presentes no movimento literário romântico que podem ser associados à ressignificação da imagem de Joana d'Arc. A referência/discussão acera do entusiasmo é um deles.

O herói romântico seria o "supra-sumo da originalidade do indivíduo singular, e do estado de entusiasmo" 210 . De fato há uma mudança na visão do entusiasmo operada pelo Romantismo. Observa-se uma grande influência e presença da ideia de "gênio" o homem capaz de ligar o ideal e o real, estabelecendo um circuito de comunicação, diferente do proposto pelo pensamento iluminista. O que muda em primeiro lugar é a ideia de mediação, o que age entre o homem e aquilo que pode e deve ser mudado de acordo com a razão. Quando se admite um pouco de "loucura" nesse processo é que a ação das massas faz sentido.

Vimos que no Romantismo inglês do século XIX o tema é recorrente e a presença do entusiasmo nos artistas é entendida em termos de uma estética discursiva. A "Poética do entusiasmo" vinda de um grande senso de liberdade significava a completa absorção no divino, a garantia de uma suprema liberdade de criação que

\footnotetext{
${ }^{209}$ VIALLANEIX, op. Cit. p. XXIX.

${ }^{210}$ NUNES, op. cit.
} 
levava ao âmago do sentido e significado de todas as coisas ${ }^{211}$. Também na França o termo foi importante para vários ícones românticos como Madame de Staël, que como já mencionamos, dedicou um capítulo ao tema do entusiasmo na sua obra $D e$ l'Allemagne, de 1810.

Assim, não podemos negar que Joana d'Arc possui elementos de uma heroína romântica. É um exemplo dessa relação interior/exterior que no seu caso é mediada pelo entusiasmo. Em seu caso pode-se ver a correlação e harmonia perfeita que leva a resultados benéficos para o todo, o coletivo, o universal. Essa característica, própria do gênio, não vem de um planejamento racionalmente verossímil apesar de ser racionalmente explicável. Com o Romantismo, o entusiasmo deixa de ser visto apenas uma força potencialmente destruidora da sociedade; ele poderia também edificá-la.

O Romantismo abandona a ideia de que a sociedade é movida pela "ação" isolada do homem abstrato singularizado na sua ratio, e o substitui por um

"indivíduo fantasioso, imprevisível, de alta complexidade psicológica, centrado na sua imaginação e sensibilidade, gênio intuitivo, investido de uma missão por lance do destino ou impulso inerente à sua personalidade que é o herói romântico, encarnação antes social do que pessoal." 212

Como ignorar as semelhanças entre essa definição e a forma como Joana d'Arc aparece na historiografia do período? Ao analisar as obras de Thierry, Guizot, Quinet e Michelet, Crossley conclui que

\footnotetext{
${ }^{211}$ MEE, J. "Blake and the poetics of enthusiasm". In: MEE, J \& Keymer, orgs. The Cambridge companion to english literature: 1740-1830. Cambridge University Press, 2004. pp. 194-210.

${ }^{212}$ CROSSLEY, op. cit. p. 15.
} 
"Os pensadores que examinamos têm em comum, o ponto de vista de que a história foi o desenvolvimento, não apenas da individualidade e subjetividade, mas também das ideias de justiça e direito que definem as relações sociais. A história como o crescimento da individualidade era também parte de uma grande história de entidades coletivas." 213

Sem dúvida, essa observação contribui para a compreensão da transformação de Joana d'Arc em heroína nacional, que passou a ser vista como um símbolo do benefício que as características individuais podem trazer à coletividade. A questão a ser criticada é que ao utilizar o termo historiografia romântica Crossley limita o entendimento, especialmente em relação à historiografia de Joana d'Arc, de um processo mais amplo que se desenvolveu e moldou o pensamento do século XIX francês, processo esse que se deu além das divisões partidárias em uma escolha coletiva pela ressignificação do passado.

Ainda que possamos aproximar nossa interpretação de vários aspectos apontados pelos autores que defendem a utilização dos termos "historiografia romântica" e "historiografia liberal" as próprias fontes nos indicam a impropriedade desses termos. Como já mencionamos anteriormente, a existência de obras escritas por monarquistasabsolutistas no período da Restauração faz com que tenhamos de ver o processo em uma perspectiva mais ampla. Se não podemos negar a influência do Romantismo na utilização e definição dos termos povo, nação e pátria, por exemplo, ao menos temos de nos questionar a ligação exclusiva do movimento a grupos liberais da política oitocentista francesa. Portanto, ou incluímos Berriat Saint-Prix e Lebrun des Charmettes no grupo dos historiadores românticos/liberais ou abandonamos esse termo para 
compreendermos de forma mais satisfatória o processo de ressignificação de Joana d'Arc no século XIX.

Se podemos dizer que Joana tornou-se uma heroína romântica em seu processo de ressignificação, não se deve dizer que foi uma historiografia romântica a responsável por esse processo tampouco uma historiografia liberal, mas um momento histórico amplo no qual os processos de ressignificação não aconteciam por obra de um determinado grupo ou partido, mas como uma opção da sociedade francesa nesse momento em que a volta ao passado é vista como uma necessidade para a construção de sua identidade e pela definição das escolhas de um país que se via como novo. Não podemos também associar somente ao evento revolucionário francês uma nova visão sobre a atuação e o lugar das massas, já que o testemunho de Hume nos prova que essa se tratava de uma preocupação muito anterior.

\section{3 - Identificando e construindo o povo e a nação}

Na primeira metade do século XIX uma das mudanças mais significativas a serem observadas no discurso político e intelectual é o fato de as referências se tornarem as entidades coletivas, muitas vezes definidas em termos de povo e nação. O primeiro termo era mais perigoso e carecia de melhores definições. O segundo conheceu um campo fértil para sua popularização, e ainda que melhor definido era imediatamente dependente da delimitação de um povo. Esses dois termos tinham uma grande interdependência, afinal de contas um povo só se reconheceria na coletividade nacional. O século XIX atribui a ambos significados que transformaram esses termos em verdadeiras entidades que passaram a ser vistas como forças motrizes da mudança e do alcance da liberdade. A forma como Joana d'Arc foi associada a esses termos foi 
fundamental para que ela ocupasse um lugar definitivo no panteão dos heróis nacionais. Nesse tópico pretendemos acompanhar algumas discussões em torno da arbitrariedade desses dois conceitos e da forma como a Donzela pôde ser associada ao processo da definição de quem era o povo e o que era a nação francesa.

Abrindo um guia de turismo atual sobre a França, não nos surpreende que a estátua de Joana d'Arc em Orléans esteja ilustrando a contracapa (Figura 17). Afinal, parece um dado inquestionável que a Donzela represente a "alma" do povo cujo país o guia pretende apresentar. Abaixo dela uma foto composta por alguns senhores sentados em frente a uma escola em Languedoc-Roussilon, expressa uma simpática sintonia. No mesmo guia temos a impressão de que a unidade e identidade nacionais francesas são dados objetivos e indubitáveis. "Os franceses têm certeza de que seu modo de vida é o melhor e de que a França é o lugar mais civilizado do planeta. Dezenas de milhões de turistas concordam com eles." 214

${ }^{214}$ Guia Visual Folha de São Paulo - França. São Paulo: Publifolha, 2009. P. 19. 


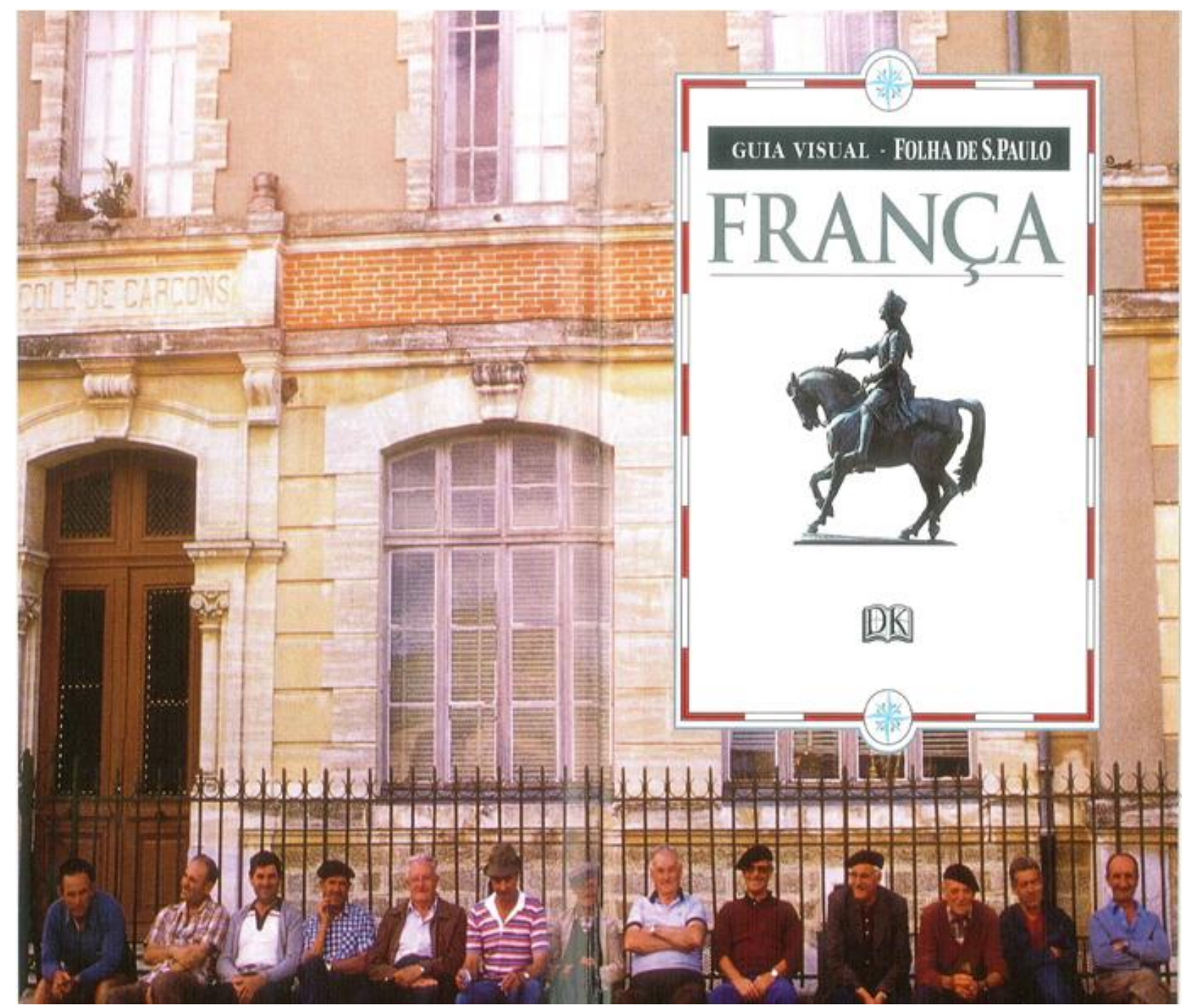

Figura 17 - Contracapa do Guia Visual Folha de São Paulo - França. São Paulo: Publifolha, 2009.

Mas como seria possível captar e identificar tal uniformidade? Jules Michelet foi em busca da identificação da unidade da França e de seu povo em suas viagens pelo interior do país. Partiu de Lyon em 1839 e com base em suas observações conseguiu relacionar o meio natural ao caráter do povo que habitava cada região. Através da paisagem ele reconheceu o camponês, percebendo uma simbiose entre ele e seu meio natural. Trata-se de uma categoria ideal, sem maiores particularidades a ponto de impedir que ele esteja à parte do grande projeto da união nacional. 
Seus esforços de reconhecimento foram publicados em $O$ povo de 1846. Ele remonta à Idade Média para identificar o surgimento do povo, um período em que já seria perceptível sua unidade em certos eventos como, por exemplo, as Cruzadas:

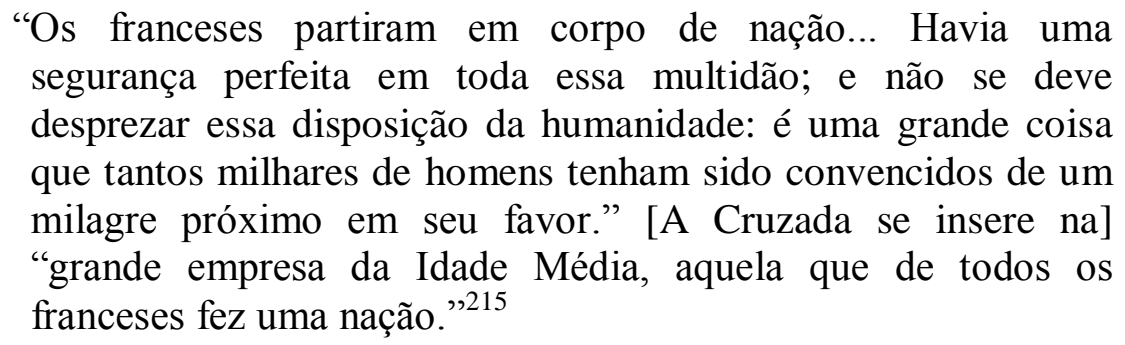

Nessa obra não há uma dissecação do termo "povo". Como lembra Viallaneix, Michelet prefere expor-se às contradições, ao mesmo tempo respeitando a unidade secular da nação e o antagonismo das classes. Por outro lado, sua definição de povo não era completamente vaga. A origem do povo francês estaria nos bárbaros a quem ele admira e seus herdeiros modernos seriam os camponeses, operários, funcionários. O que os unifica, tornando-os povo é o fato de estarem submetidos a diferentes tipos de servidões. O mais importante é que Michelet faz questão de eximi-los de toda culpa: “essa multidão não é má em si. Suas desordens derivam em grande parte de sua situação, de sua sujeição à ordem mecânica que para os corpos vivos é em si uma desordem, uma morte.",216

A aglutinação das pessoas na coletividade "povo" é uma tendência natural do homem que já nasce em busca do convívio social:

\footnotetext{
${ }^{215}$ MICHELET, Histoire de France. apud VIALLANEIX, P. Prefácio. In: MICHELET, O povo. São Paulo: Martins Fontes, 1988. P. XVI.

${ }^{216}$ VIALLANEIX, P. "Prefácio". ...P. XVIII.
} 
"Por pouco que eu o observe (o homem) em seu próprio nascimento, vejo-o sociável. Antes de abrir os olhos, ele ama a sociedade; chora quando é deixado só... Como admirar-se disso? No dia que se diz ser o primeiro, ele deixa uma sociedade já bem antiga, e tão doce! Foi por ela que ele começou; velho de nove meses, cumpre-lhe divorciar-se, entrar na solidão, procurar às cegas uma sombra da perdida união, que lhe era tão cara". ${ }^{217}$

Após o nascimento a pátria substitui o vínculo materno. Ela dá o sentido da vida humana e toda a sociedade é sua família, seus irmãos, unidos pela amizade natural do povo. Foi essa amizade, essa união fraternal, amorosa e natural que Michelet teria percebido em suas viagens pela França reconhecendo um verdadeiro povo, formador de uma grandiosa nação. Temos no testemunho de Michelet um exemplo claro da necessidade de identificação que passava pelo pertencimento ao corpo coletivo, nesse caso o da nação.

Aproximadamente um século e meio após a viagem de Michelet, o escritor inglês Graham Robb percorre 22.500 quilômetros de bicicleta pelo interior da França. Durante essa viagem o que ele pôde perceber foi um país muito diferente do que ele denominou como a "França de sempre", o que o levou a descobrir um país "em que até pouco mais de cem anos atrás o francês era uma língua estrangeira". ${ }^{218} \mathrm{O}$ resultado dessa viagem e de mais quatro anos em bibliotecas deu origem a um livro que no lugar de apresentar elementos que identifiquem os habitantes daquele território como um povo homogêneo, ou imagens da unidade daquela nação, demonstra o que ele denominou de uma verdadeira imprevisibilidade do país.

Em suas pesquisas Robb remonta ao final do século XVIII para investigar a validade da hipótese de que a popularização do discurso da unidade nacional francesa,

\footnotetext{
${ }^{217}$ MICHELET. Histoire... p. 174.

${ }^{218}$ ROBB, Graham. A Descoberta da França - uma jornada histórico geográfica da Revolução à Primeira Guerra Mundial. Rio de Janeiro: Record, 2007. P. 25.
} 
naquele momento, teria sido seguida de um projeto de nacionalização do país particularmente eficaz ao longo de século XIX. Esse projeto nacionalizante buscou se efetivar, sobretudo, a partir de medidas estatais. Mas no decorrer desse processo o autor observa que "É possível que houvesse algo chamado sociedade francesa, mas seus traços são difíceis de discernir na história do Estado." 219

Algo que pode dar ideia da imprecisão do que seria a França era o efetivo desconhecimento do seu território. Em 1799, o mapa da França ainda não estava publicado na íntegra. "Até meados do século XIX pouca gente vira o mapa da França ou ouvia falar em Carlos Magno ou Joana d'Arc." ${ }^{, 20}$ Robb descreve as dificuldades dos membros das expedições que deveriam fazer o mapeamento do território francês com as populações locais, desde o século XVIII. Há o caso pitoresco de um geômetra da equipe de Cassini, cuja expedição instalou as bases para o primeiro mapa completo e confiável da França. O rapaz, em 1740, após pernoitar em Les Etables para continuar sua jornada de reconhecimento e mapeamento da região da cordilheira do Mézenc, foi assassinado pelos moradores locais que viram nele um forasteiro com estranhos e perigosos instrumentos de trabalho. O que dificultava ainda mais o trabalho era o fato de que nessas regiões não se falava o francês, o que na verdade era mais comum na "grande bacia parisiense".

Por volta da década de 80 do século XVIII "Mesmo antes de estar concluído, era óbvio que o mapa da França, com sua ortografia padronizada e símbolos homogêneos, era muito mais coerente do que o país em si." ${ }^{221}$ A equipe de Cassini havia colocado no mapa mais de 500 mil lugarejos obscuros. Apesar dos muitos erros

\footnotetext{
${ }^{219}$ Idem, p. 124.

${ }^{220}$ Idem, p. 48.

${ }^{221}$ Idem, p. 237.
} 
desse trabalho, essas localidades abriram a imaginação dos parisienses que criaram a noção idealizada de "França profunda." Uma nova expedição cartográfica foi realizada entre 1818 e 1841 culminado na elaboração da "Carte de l'état-major" publicado em 1841. Essa necessidade vinha também da nova configuração administrativa implantada no território após a Revolução. A divisão do país em "departamentos" tinha como um dos objetivos suprimir a divisão norte-sul. As barreiras linguísticas foram ignoradas, os nomes departamentais se referiam em sua maioria, acidentes geográficos e os nomes anteriores de regiões e seus habitantes - como burgúndios, bretões, normandos - foram abandonados em nome da identificação com a identidade nacional.

A diversidade linguística era considerada uma das principais barreiras à construção dessa nacionalidade. No final do século XIX

"havia cerca de 55 dialetos e centenas de subdialetos
identificados, que pertenciam a quatro grupos linguísticos
distintos - românico (francês, occitano, franco-provençal,
catalão e línguas itálicas faladas na Corse e na fronteira
italiana); germânico (flamengo, frâncico e alsaciano); celta
(bretão); e euscárico (basco) um grupo isolado. Os inúmeros
outros eram ou desconhecidos, ou não eram reconhecidos.",222

Uma preocupação de longa duração já que, em 1972, o presidente Pompidou declarou que "não há espaço para línguas regionais em uma França destinada a deixar sua marca na Europa."223 Dois séculos antes, o abade Henri Grégoire, o mesmo que criou o termo vandalismo, havia mandado às prefeituras um questionamento sobre os patois - dialetos locais que não eram variantes regionais do idioma vigente. Tratava-se de um termo depreciativo. Em seu relatório "Sobre a necessidade e os meios para se

\footnotetext{
${ }^{222}$ Idem, p. 88.

223 apud ROBB, op. cit. p. 94.
} 
exterminar o patois e universalizar o uso da língua francesa", o abade deixava claro que o patois era símbolo do despotismo, superstição, subserviência e ignorância medieval.

Robb chama a atenção para o fato de que a França moderna foi construída tendo como base um processo de supressão das memórias, sendo que a data do aniversário nacional, por exemplo, pode ser vista como uma obliteração de acontecimentos e culturas. Não há dúvidas de que esse processo não se deu de forma pacífica, sem reações por parte dos habitantes do interior. Como afirma Christian Amalvi em algumas províncias, a memória da Revolução era nefasta, fato decorrente, na maior parte das vezes, das tentativas de uniformização que se seguiram à mudança de governo.

No caso da língua Robb lembra que, segundo os próprios falantes, quase ninguém falava corretamente o francês. "Na terra de mil línguas, o monolingüismo tornou-se a marca do indivíduo instruído." ${ }^{224}$ A elite francófona via os dialetos como desvios da língua oficial.

O autor sustenta a hipótese de que a visão republicana de um país unido era fantasia de uma pequena elite parisiense. Uma questão de centralização geográfica alimentava essa ideia, já que era muito difícil viajar pela França sem passar por Paris. As estradas que partiam da cidade eram, na verdade, grandes avenidas que contribuíram para que o "império parisiense" se propagasse por toda a França e o Império Francês para toda a Europa.

O interesse pela França interiorana foi acionado de tal forma que levou a um grande desenvolvimento do turismo impulsionado pela criação dos patrimônios 
nacionais. Foram de grande importância nesse processo as viagens de Prosper Merimée que entre 1834 e 1852 conseguiu o tombamento de quatro mil construções.

Sir Walter Scott suscitou grande interesse na França pelo Vale do Loire a partir de seus romances. Os turistas ingleses, com seus relatos de viagens, foram particularmente eficazes na construção do orgulho nacional francês. Ao mesmo tempo desenvolveu-se um "mercado negro" do qual faziam parte vendedores de quinquilharias e negociantes de antiguidades que ganhavam dinheiro com a venda de propriedades confiscadas da Igreja e da Aristocracia. Além disso, demoliam-se castelos e vendiam-se os entulhos. A "bande noire", como esse grupo ficou conhecido, tornou-se famosa pela devastação que causou. Ao mesmo tempo eles identificavam os tesouros arquitetônicos e quando descobriram que podiam ganhar dinheiro contribuíram para sua a preservação.

Através dessa ideia de patrimônio, do discurso de unidade, Paris produziu, inventou o interior da França. As chamadas "especialidades" que começaram a aparecer são fruto mais do talento publicitário do que a essência de uma região. "Foi a partir de Paris que muitos pratos 'da província' chegaram às províncias. (...) Grande parte do que passou a ser visto como francês ou era peculiar a Paris, ou imitava algumas coisas parisienses." 225 Os criadores da "cultura francesa" em sua maioria autores, pintores, músicos , nasceram ou trabalhavam há muitos anos na capital.

O paladar fora de Paris estava mais habituado ao pão duro e seco. Uma anedota pessoal elucida a força com a qual foi instituída e a importância que adquiriu a ideia de uma identidade do interior da França. Em uma das refeições no Castelo de Cerisy-laSalle, uma pequena vila na Normandia, onde aconteceu o colóquio "De herética à Santa - os processos de Joana d'Arc revisitados" em 2009 tive a oportunidade de me sentar ao 
lado do professor Philippe Conatamine. Ele, um grande especialista da Guerra dos Cem Anos e primeiro diretor do Centro Joana d'Arc em Orléans. Após ouvir minhas lamentações sobre o quanto eu tinha me alimentado mal em Paris por ter comido apenas baguete, crepes e paninis, Monsieur Contamine me tranquiliza: "Agora você está no coração da França; a França dos castelos e a França do campo.”

A crença em uma França "eterna", de identidade própria e bem definida parece ter ganhado até mesmo os espíritos mais argutos. Uma entidade viva, dotada de um coração que lhe dá as características mais definitivas. A "província” ao longo do século XIX foi sendo idealizada como um local privilegiado para entrar em contato com o povo e a cultura francesas, ao contrário da cosmopolita capital.

A chamada "literatura de província" se compunha de canções folclóricas e lendas. “(...) organizadas e enfeitadas para o mercado parisiense por escritores que já

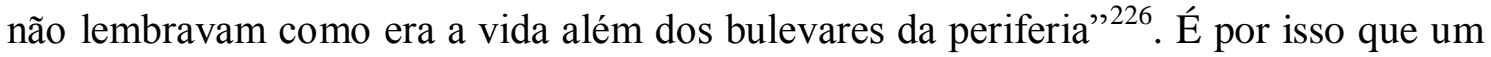
folclorista do final do século XIX, em visita à Bretanha, se espanta: ninguém havia ouvido falar em bardos ou druídas. Até mesmo as modas que pareciam vir da Bretanha eram de Paris. Nesse mesmo período o turismo de massa faz uma recriação do interior mostrando postais com atividades típicas do local que já haviam desaparecido. Enquanto há toda essa diversidade entre a população que habitava um mesmo país cujos componentes pouco se identificavam com as famílias do vilarejo ao lado, os irmãos Grimm estavam percorrendo a Europa para recolher "os folclores nacionais". As antiguidades nacionais se inscreviam num tesouro comum europeu. "Por consequência, nada de nacionalismo patriótico sem cosmopolitismo intelectual." ${ }^{227}$ Essa construção

\footnotetext{
${ }^{226}$ Idem, p. 358.

${ }^{227}$ THIESSE, A-M. op. cit. p. 66. Tradução nossa.
} 
se deu sem dúvida projetando a ideia de unidade sem levar em conta as particularidades regionais.

Faz parte desse processo, já anteriormente tão bem definido por Eric J. Hobsbawm, como a Invenção das Tradições ${ }^{228}$, a ressignificação de Joana d'Arc. De um culto regional, restrito a Orléans, a heroína passa a ser associada ao conjunto da nação francesa, não sendo ocasional o fato de terem partido de Paris grande parte dos esforços para enquadrá-la no panteão dos ícones da pátria. Um dos exemplos ilustrativos desse fenômeno é a constituição da casa natal de Joana d'Arc como centro de memória da heroína e de peregrinação a partir da iniciativa estatal.

\subsection{1 - Domrémy - a fronteira como local de peregrinação nacional}

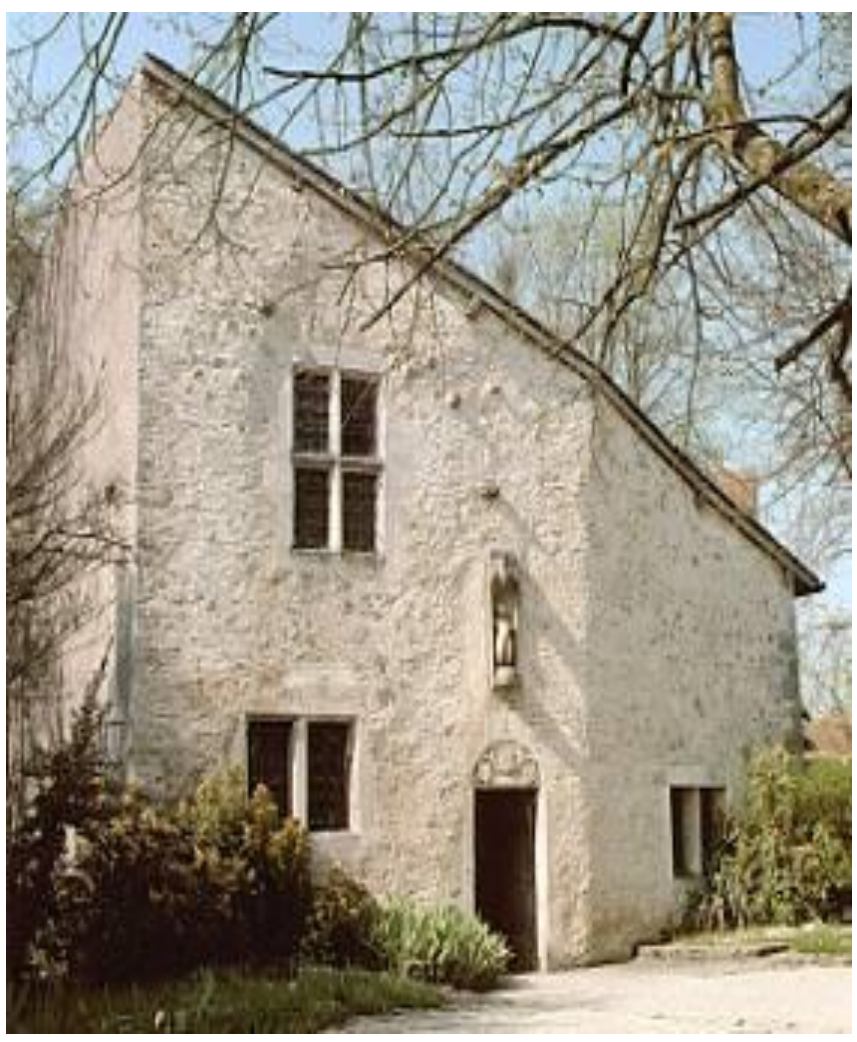

Figura 18 - A casa natal de Joana d'Arc em Domrémy. Disponível em http://www.vosges-etvacances.com/loisirs/details_20.html. Acesso em 04/09/10.

${ }^{228}$ HOBSBAWM, Eric J. \& RANGER, Terence (orgs.). Rio de Janeiro: Paz e Terra, 1984. 
Em 20 de junho de 1818, um descendente da família Gérard vende a casa onde nasceu Joana d'Arc em Domrémy ao departamento de Vosges. Conforme suas palavras ele agiu "determinado pelo desejo de fazer, em favor dos habitantes do departamento de Vosges, uma concessão que lhes será agradável, e mais ainda pelo amor de sua pátria e do rei de França". ${ }^{229}$ Em meio a uma solenidade para a qual várias canções foram especialmente compostas, o conjunto monumental em torno da casa da Donzela foi inaugurado em 1820. Ao longo do século XIX o sentido daquele local de culto mudou. Entre 1820 e 1840 a motivação era basicamente o nacionalismo anti-inglês, e a partir de 1840 a casa de Joana passa a adquirir um aspecto religioso e a visita a ela ganha uma conotação de peregrinação devocional ${ }^{230}$.

Domrémy é uma pequena cidade localizada muito próxima à fronteira da França com a atual Alemanha. Está claro que um dos propósitos do favorecimento do culto à Joana por meio da criação de um monumento à sua memória está relacionado às tentativas de união das diversas regiões francesas em torno do ideal da nação. Se consideramos, como afirma Robb, que a França é uma projeção de Paris, poderíamos afirmar que Paris une as memórias regionais, no caso de Joana memórias centenárias especialmente em Orléans e Rouen, transformando-as em repositórios da identidade nacional. $\mathrm{O}$ culto à Joana é uma projeção de Paris às províncias. Em Orléans, por exemplo, o culto secular fora interrompido pela Revolução, mas para a cidade a interrupção não fazia sentido. Já em Domrémy até a "inauguração" da casa de Joana como monumento nacional em 1820 não existia culto à Donzela. A preocupação parte

\footnotetext{
229 QUICHERAT, J. Procès de condamnation et de réhabilitation de Jeanne d'Arc, dite la Pucelle, publiés pour la première fois d'après les manucrits de la Bibliothèque Nationale, suivis de tous les documents historiques qu'on a pu réunir, et accompagnés de notes et d'éclaircissements; Volume 5. Paris, chez Jules Renouard. p. 38.

${ }^{230}$ COLIN, Marie-Helène. "Visiter Domrémy au XIXe siècle". In: MARTIN, Philippe (org). Jeanne d'Arc: les métamorphoses d'une hérö̈ne. Place Stanislas, 2009. pp. 37-45.
} 
do governo em Paris, com o objetivo de alcançar uma região de fronteira ligando-a a história de todo o povo francês. Joana mais uma vez é a heroína perfeita, pois era alguém da fronteira, de uma região onde se falava algum patois e é apresentada a todos como alguém que superou qualquer particularidade regional em nome da pátria.

As cidades por que passou como Vaucouleurs, Chinon, Orléans e Rouen desenham uma verdadeira peregrinação ao longo do território francês. Essa epopéia une, a partir das cidades por onde ela passa, pontos dispersos, locais muitos dos quais estavam dominados pelos ingleses na época de Joana. Em nossas fontes observamos a preocupação dos autores em começar a história específica de Joana d'Arc descrevendo a parte físico-geográfica de Domrémy, detendo-se nos rios e acidentes geográficos que delimitavam a fronteira, esclarecendo como se dava a administração da região como parte do território que pertencia ao reino da França. ${ }^{231}$

Quando a casa natal de Joana d'Arc foi aberta à visitação pública, a prefeitura de Orléans não só enviou uma delegação como também cunhou uma medalha comemorativa para marcar o evento em uma tentativa até então inédita de união da cidade que a libertou à cidade em que nasceu.

\footnotetext{
${ }^{231}$ Como vemos em Lebrun des Charmettes: "Une contrée fertile, abondante en bois, en rivières et en pâturages, s'ëtend entre les duchés de Bar et de Lorraine; et, resserrée par ces deux provinces, ne tient, pour ainsi dire, que par un point à la Champagne, dont elle fait cependant partie. Comprise dans le domaine immédiat de la couronne depuis le mariage de Phihppe le Bel avec l'héritière de Navarre et de Champagne, il semble que les liens qui rattachaient à la France avaient augmenté de force en raison des efforts des princes voisins pour les détruire. Presque isolée, placée à Fune des extrémités du royaume, entourée d'ennemis naturels, elle leur présentait sans cesse une proie facile à dévorer, et il n'était guère possible que cette facilité ne tentât souvent leur ambition. Elle ne pouvait remédier au danger de sa situation que par des efforts continuels de dévouement, de fidélité et de zèle; et l'on a généralement remarqué que l'esprit national, sujet, comme presque toutes les facultés morales et physiques, à s'éteindre dans le repos, ne s'accroît et ne se développe jamais davantage que dans les situations où il a le plus souvent l'occasion et la nécessité de s'exercer. Au milieu de cette contrée véritablement française, dans un riant vallon arrosé par la Meuse, à deux lieues au nord de Neufchâteau, à trois lieues au sud de Vaucouleurs, s'élèvent le village de Greux et le hameau de Domremy, qui, séparé de Greux par un faible intervalle, ne formait au quinzième siècle qu'une dépendance de ce village. Des pâtres, des laboureurs, quelques pêcheurs attirés en ce lieu par la proximité d'une rivière poissonneuse, étaient a peud'une rivière poissonneuse, étaient a peu près les seuls habitans de ce séjour champêtre”. Op. cit. vol 1. p. 237-238.
} 


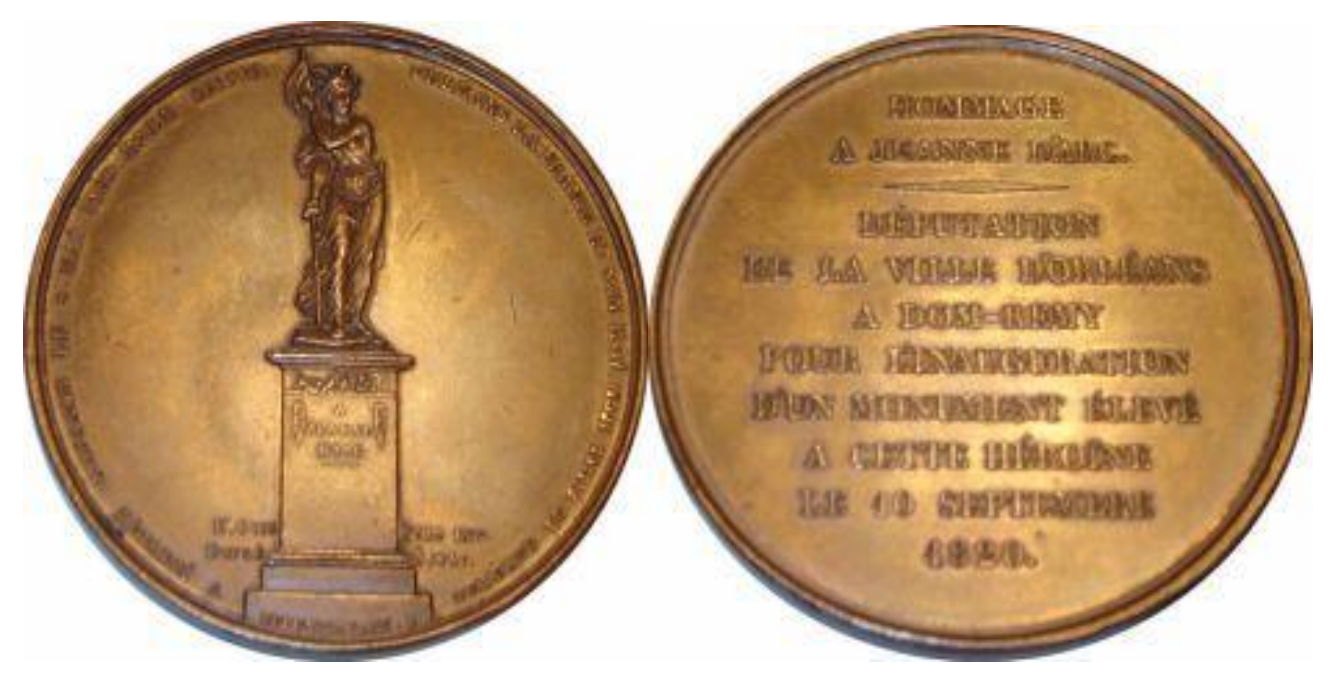

Figura 19: Jeanne d’ Arc - Députation Orléans - Domrémy - 1820 - Médaille n² disponível em: $\quad$ http://www.medailles-jeannedarc.fr/index.php?tag/Jeanne\%20d\%20Arc\%20\%20D\%C3\%A9putation\%20Orl\%C3\%A9ans\%20-\%20Domremy\%20-\%201820\%20\%20M\%C3\%A9daille\%20n\%C2\%B02 acesso: 18/04/12

A importância adquirida pela casa natal de Joana d'Arc no século XIX era cada vez maior. Ao lado da entrada foi colocada uma cópia de uma das estátuas mais conhecidas de Joana, feita pela princesa Marie de Orléans em 1831, denominada Jeanne d’Arc en prière (Figura 21). Em Domrémy há uma redução em bronze dessa estátua e chama a atenção o fato do rei, Luís Felipe, após a morte da princesa, ter mandado colocar exemplares da obra em quatro locais simbólicos: Domrémy, Orléans, Chinon e Eu. A estátua de Domrémy foi inaugurada em 1843 na presença de guardas e oficiais. Essas estátuas uniam claramente pontos diversos do território em um esforço partindo do governo central para transformar essa memória na identidade de todos os franceses. 


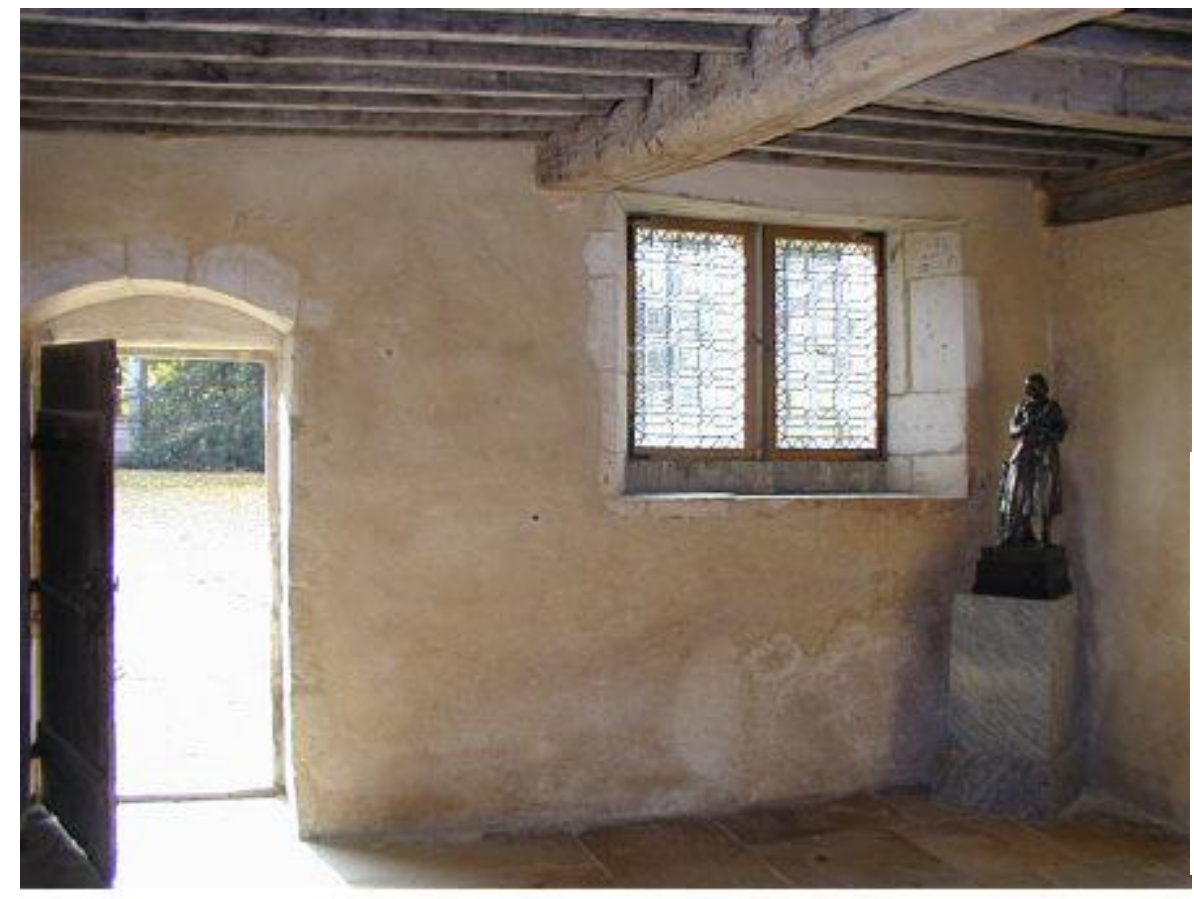

Figura 20: Foto do interior da casa natal de Joana d'Arc, onde foi colocada uma miniatura da estátua Jeanne d'Arc en prière.

Fonte:http://www.stejeannedarc. net/dossiers/maison natale.php

Domrèmy - maison natale, piece principale - aoūt 2004

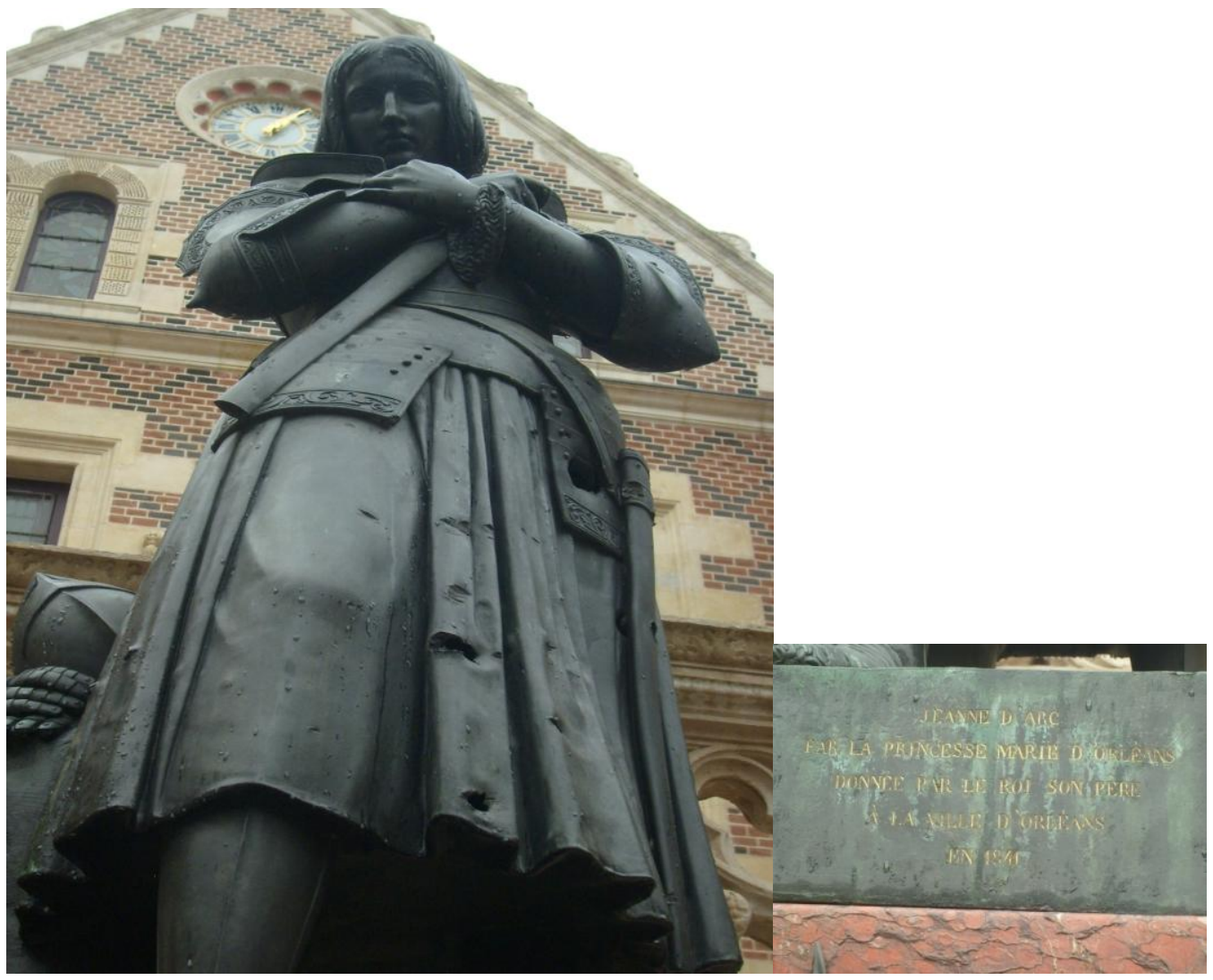

Figura 21: Jeanne d'Arc en priére. Marie d'Orléans, 1838. Orléans. Foto: arquivo pessoal, 2009. 
Os eruditos locais, durante o século XIX, vão buscar, em função de sua origem, fazer de Domrémy parte da Champanha ou da Lorena.

"A questão principal é a seguinte: Joana d'Arc se sentia mais lorena ou barroise ${ }^{232}$ ? Quem era para ela o duque de Bar? Seu 'príncipe territorial'? O mais claro é que ela se sentia sobretudo pertencente ao Reino da França, que sua devoção era ao rei da França."233

A atualidade dessa discussão para a política francesa é veemente. Vimos que por ocasião do $600^{\circ}$ aniversário de Joana d'Arc, o presidente da França, Nicolas Sarkozy visitou a casa de Joana em Domrémy, ato que desagradou enormemente a candidata ao Elisées, Marine Le Pen. A disputa que os dois travam por Joana d'Arc no cenário político não é recente. Em 2007 Sarkozy disse em um discurso que "Joana pertence a todos os franceses", em reação às investidas da Frente Nacional em fazer da Donzela seu ícone. O presidente chegou a se perguntar como a direita republicana e o centro puderam permitir que a extrema direita a "confiscasse".

Em reposta a essa visita, Marine Le Pen disse que fora seu pai, Jean-Marie Le Pen, o responsável por reabilitar a memória de Joana d'Arc nas últimas décadas, devolvendo-a seu lugar na vida política francesa. Graças à Frente Nacional e a homenagem prestada todos os anos que Joana ainda está viva. .

Nesse embate travado logo no início de 2012, Le Pen disse algo de grande repercussão na imprensa francesa:

\footnotetext{
${ }^{232}$ Do condado de Bar.

${ }^{233}$ Verbete "Domrémy". In: BOUZY, O. , CONTAMINE, P. \& HÉLARY, X. Jeanne d'Arc: Histoire et dictionnaire. Bouquins, 2012. p. 666.
} 
“Joana d'Arc pertence a todos os franceses, isso é a primeira coisa. (...) Vejo que Sarkozy está correndo atrás de mim, mas eu tenho convicções mais fortes, um coração mais puro e pernas mais longas... Portanto, vai ter muitas dificuldades para me apanhar. " 234

Essa frase de Marine Le Pen causou a reação da opinião pública e percebem-se nela referências a partir das quais ela propõe sua superioridade em relação à Sarcozy fazendo, logo de início, uma projeção da pureza do coração de Joana d'Arc e suas supostas convicções nacionalistas em sua própria personalidade. Trata-se de uma referência cristã à pureza do coração, virtude básica para se ganhar o Reino dos Céus segundo a mensagem de Cristo e com tal analogia Marine alcança ainda mais os eleitores católicos. Trata-se ainda de uma forma sutil de expressar sua visão a respeito da imigração que descaracterizaria a verdadeira França e uma forma de relembrar as origens estrangeiras de Sarcozy; o "coração mais puro" remete à ideia de que Le Pen é mais francesa de que seu oponente.

A Frente Nacional usa Joana d'Arc como ícone de um discurso que se opõe ao que eles denominam a "defesa e subserviência ao mundialismo", uma tendência que estaria em voga nas práticas e discussões dos seus opositores sendo a responsável pelo abandono da França e de sua população. O "mundialismo" refere-se basicamente à extinção das fronteiras nacionais em nome da livre circulação de mercadorias. Os efeitos nefastos do fenômeno, no entanto, não estariam restritos ao aspecto econômico, como veremos mais adiante.

\footnotetext{
${ }^{234}$ Disponível em: http://tempsreel.nouvelobs.com/le-reveil-politique/20120106.OBS8201/les-jambes-dele-pen-et-la-bombe-de-boutin.html. Acesso em 20/01/2012. Tradução nossa.
} 
A discussão acerca dos problemas econômicos vindos da mundialização da economia está marcada pela ideia de que a justiça social só seria possível no quadro nacional. O Estado, neutralizado pelo mercado mundial, não pode cumprir seu papel de árbitro em favor da justiça social ${ }^{235}$.

A mundialização, no entanto, traz outras conseqüências terríveis, segundo os partidários da Frente Nacional. Ela é vista como a causa do declínio da França que começou a perder sua independência, seus valores e o mais importante sua IDENTIDADE, já que à livre circulação de mercadorias seguiu-se a livre circulação de pessoas, levando a deslocamentos populacionais e obrigando a França a confrontar-se com o problema dos imigrantes, acusados de descaracterizar os valores e princípios fundamentais da República Francesa.

A Frente Nacional apela, a partir de suas propostas eleitorais, para a reconstrução da verdadeira França e nesse contexto a necessidade de que alguém com o coração "mais puro" esteja à frente da República é urgente, a única possibilidade de salvação para o país. Nesse quadro argumentativo Joana d'Arc foi o símbolo escolhido pela Frente Nacional, pois sua "luta contra o estrangeiro e pela França" é reatualizada no discurso anti-imigracionsta em uma verdadeira Cruzada contra a mundialização e seus efeitos nefastos para a sociedade francesa. Jean-Marie Le Pen discursando à frente da estátua de Joana d'Arc na Place des Piramides em Paris, no dia em que a Frente Nacional comemorou o $600^{\circ}$ aniversário de nascimento da Donzela, disse que sim, Joana pertence a todos os franceses, mas

\footnotetext{
${ }^{235}$ Cf. La mondialisation, ennemie de la justice sociale. Texto de Maurice Allais, disponível em: http://www.missionboutin.fr/pdf/contribution front national.pdf. Acesso: 20/02/12. Tradução nossa.
} 
"com certeza ela não pertence aos partidos que só falam dela em períodos eleitorais. Aos partidos que entregaram a França ao europeísmo e ao mundialismo, que querem dissolvê-la em uma Europa federal, que abandonaram a guarda milenar das fronteiras, que negam a legítima prioridade nacional, que organizaram uma imigração estrangeira massiva, a qual não respeita nenhum dos princípios que fizeram agir Joana e que a levaram à morte." 236

Le Pen, a filha, apesar de não ter discursado nesse dia, deixou também seu recado ao ser entrevistada. Não se tratava apenas de homenagear Joana, mas, sobretudo de compartilhar de seus valores. Seria incoerente, portanto a homenagem de Sarcozy, cujo mandato representou "o abandono da soberania nacional, o desaparecimento da liberdade do povo, e a islamização progressiva do nosso país." 237

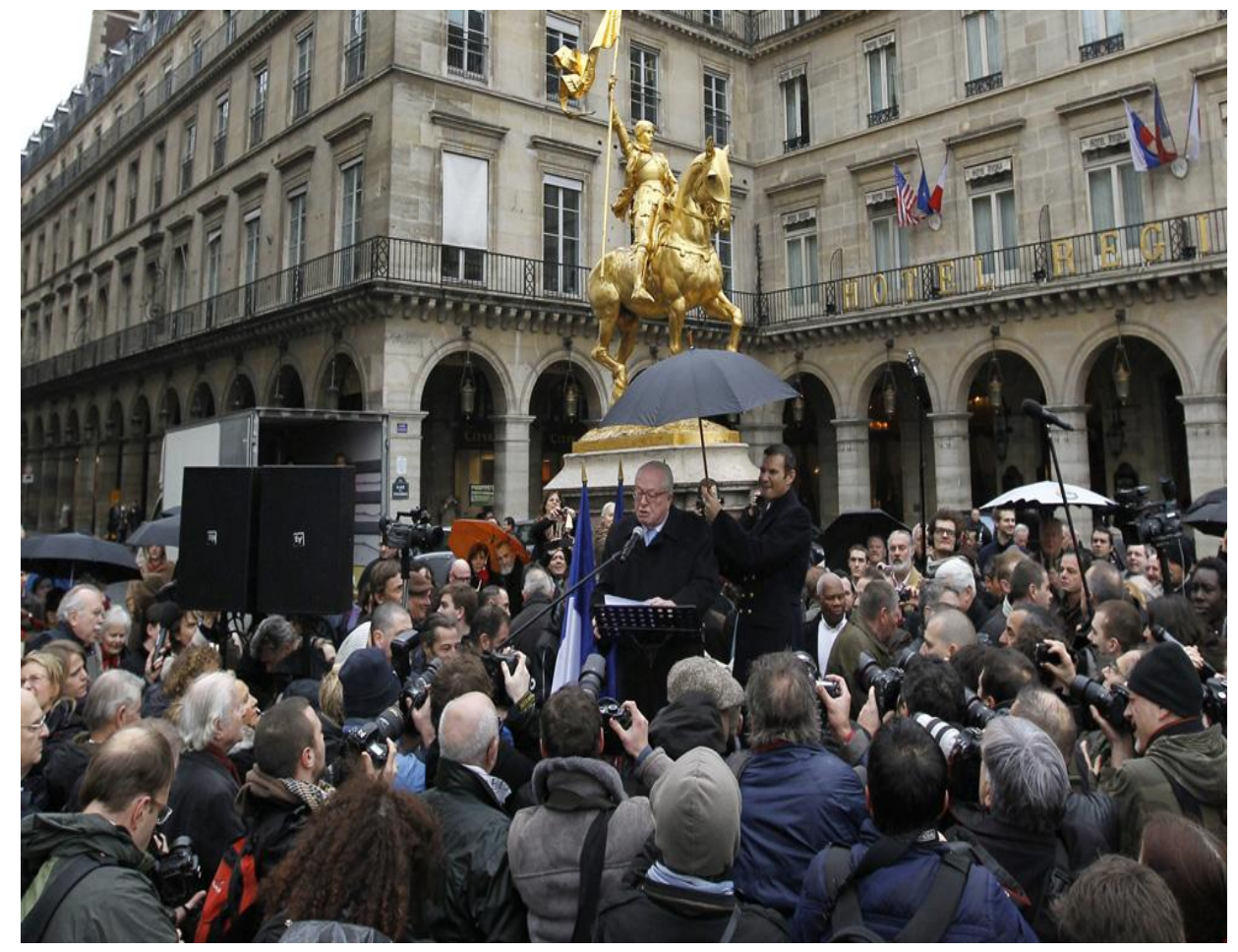

Figura 22: Jean Marie Le Pen discursa em frente a estátua de Joana d'Arc na "Place des Pyramides" em Paris, na comemoração pelos 600 anos de nascimento de Joana d'Arc. A festividade foi organizada pela Frente Nacional no dia 07 de janeiro de 2012.

Disponível em: http://pasidupes.blogspot.co $\mathrm{m} / 2012 / 01 / 600 \mathrm{e}-$ anniversaire-jeanne-darcsarrache.html. acesso em 20/02/12.

\footnotetext{
${ }^{236}$ Disponível em: http://tempsreel.nouvelobs.com/election-presidentielle-2012/20120107.OBS8295/lefn-exalte-jeanne-d-arc-symbole-de-nationalisme.html. Acesso em 20/01/12. Tradução nossa.

${ }^{237}$ Disponível em: http://www.letelegramme.com/ig/generales/france-monde/france/jeanne-d-arc-marineet-jean-marie-le-pen-repliquent-a-sarkozy-07-01-2012-1557832.php. Acesso em 10/01/12. Tradução nossa.
} 


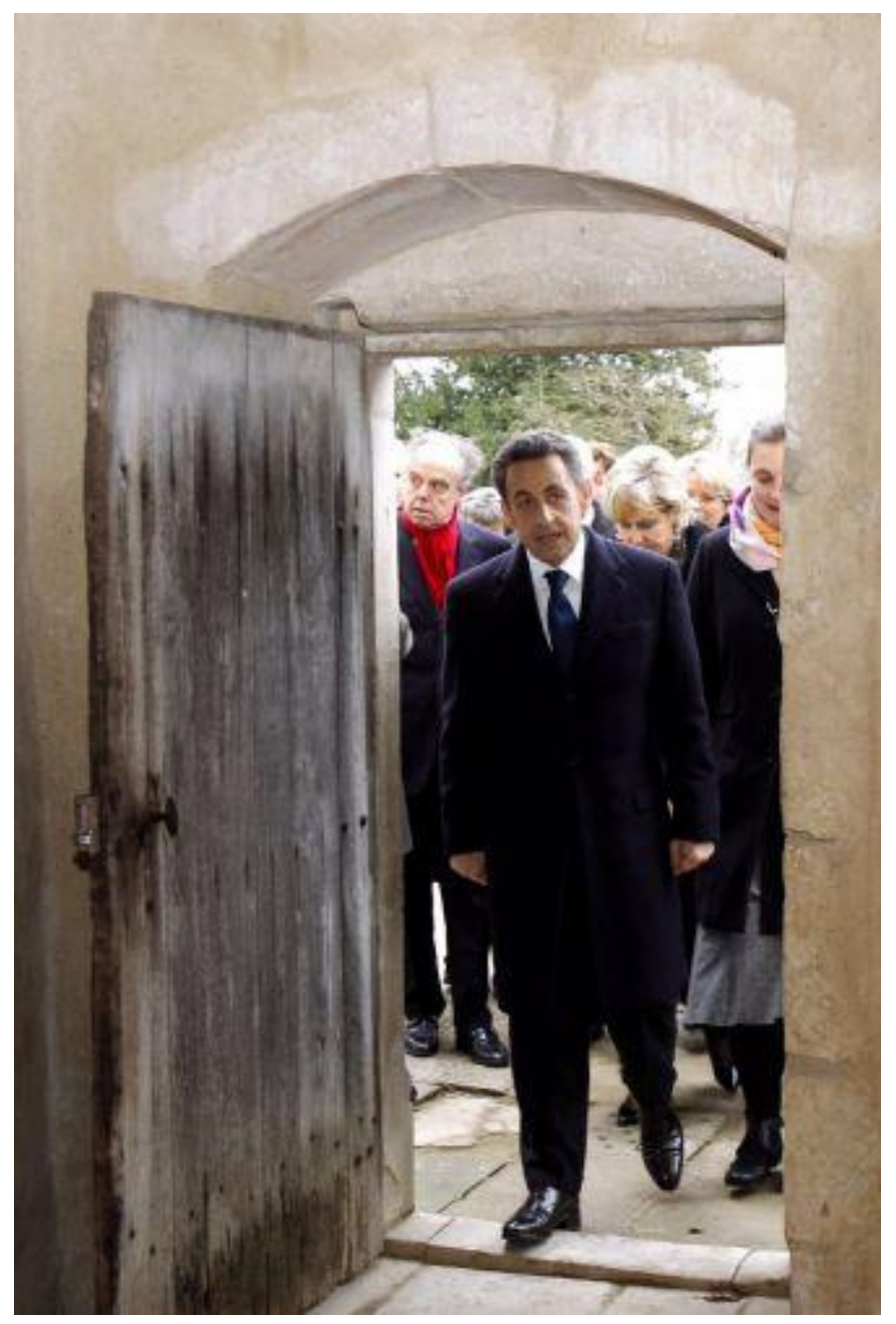

Figura 23: Nicolas Sarkozy entrando na casa natal de Joana d'Arc em Domrémy; 6 de janeiro de 2012.

Disponível em: http://noticias.uol.com.br/blogs-ecolunas/coluna/luiz-felipealencastro/2012/01/11/sextocentenario-do-nascimento-dejoana-darc-mexe-com-as-eleicoesna-franca.htm 15/01/12.

Esse fenômeno atual da política francesa em relação à Joana d'Arc demonstra o quão profunda é a identificação da França com a heroína. Sua memória é capaz de suscitar debates relacionados às questões centrais enfrentadas pelos franceses atualmente, que passam pela definição de sua identidade em relação à nacionalidade. Uma discussão que desponta no momento de uma grave crise econômica, através da procura de bodes expiatórios que seriam responsáveis pelo declínio da França ao afastála de sua real identidade e posição no mundo. É importante observar que o momento responsável por tecer essa identificação o fez a partir de um projeto estatal que visava unificar as regiões e seus habitantes em um único e mesmo ideal identitário. 
As fontes que analisamos do período da Restauração, o mesmo em que há a institucionalização do culto à Joana em sua casa natal, escritas, não por acaso por parisienses unem-se a esses esforços. Como vimos, não se trata de um fenômeno específico desse período e nem podemos separá-lo em termos de "posição partidária" em relação às fontes das décadas posteriores. Tudo faz parte de um mesmo processo da ressignificação do passado que não se fez a partir de um discurso homogêneo. Para Lebrun des Charmettes, escrever sobre Joana é escrever sobre a nação que não pode ser feita sem heróis. Como poderíamos ignorar que esse autor evoca esses pilares da construção de uma identidade nacional ainda que seja sub-prefeito de Calais durante o período da Restauração no momento em que escreve essa obra? A historiografia ao taxar Lebrun de monarquista e restaurador, permite levar à frente a distinção clássica escritores monarquistas versus escritores liberais e dar a esses últimos o mérito de evocar pela primeira vez a relação entre Joana d'Arc e nação francesa.

Analisar a imagem construída para Joana nessa primeira metade do século XIX nos faz questionar o próprio advento do nacionalismo, que não foi necessariamente obra de um liberalismo republicano. Lebrun des Charmettes, fascinado pelos épicos clássicos de fundação, como a Eneida de Virgílio, começa a escrever em 1805 Orléanide, publicado em 1819, poema em 28 cantos que narra a libertação de Orléans por Joana d'Arc, obra em que compara os orleanenses aos espartanos de Leônidas. Para ele, assim como Roma tem Rômulo e Remo, a França tem Joana d'Arc, com a vantagem de que sua história é totalmente comprovada através de documentos. Ele faz uma comparação com os heróis clássicos, e não com as mulheres bíblicas, já que para ele a característica essencial de Joana é o devotamento à nação. Há a busca de uma origem nacional na Idade Média a partir de um modelo clássico, de conteúdo amparado pela documentação 
da época a qual ela cita exaustivamente em notas de rodapé para comprovar os fatos narrados.

Esses exemplos nos mostram que mais do que a expressão de um partidarismo, a escrita desses autores era parte de um contexto intelectual mais amplo, que o gênero narrativo do qual lançam mão os impelia a expressar a visão mais geral da sociedade de que participavam. Por mais que defendam o poder absoluto do rei, mostram a força da ação coletiva, por mais que condenem o liberalismo ${ }^{238}$, mostram Joana como exemplo do indivíduo excepcional. Não estamos afirmando, porém, que esses autores eram românticos e liberais sem terem consciência disso. Mas ao contrário, questionamos a condição do evento revolucionário francês e a defesa de seus ideais supostamente originais para que esses temas fossem explorados.

Ao mesmo tempo, devemos ao período da Restauração os esforços para levar o culto de Joana à fronteira numa tentativa de nacionalizar sua imagem, ainda que estivesse associada à defesa do rei. Mas o projeto de uniformização não se deve apenas aos partidários da Revolução. E essa projeção a toda a França foi fundamental para que hoje ela ilustre a contracapa do mesmo guia turístico que se esforça para conceder uma unidade àquele país que vai apresentar aos leitores; com as palavras refere-se à sofisticação. Com a imagem, essa estátua de Joana d'Arc basta para definir o que é a França.

\footnotetext{
${ }^{238}$ Charmettes escreveu uma obra intitulada "Epístolas políticas sobre nossas extravagâncias" em que condena os exageros do liberalismo.

"Et qui dit liberté, dit désordre et pillage.

Tu rêvas une aimable et douce égalité

Et c'est une impossible et folle iniquité.

Enfin tu crus trouver un appui tutélaire

Dans la vertu du nombre et le droit populaire;

Et ce dogme imprudent, de cahots en cahots,

Nous conduit dans l'abîme, et nous mène au chaos."
}

Epîtres politiques sur nos extravagances. Paris, 1831. p. 28. 

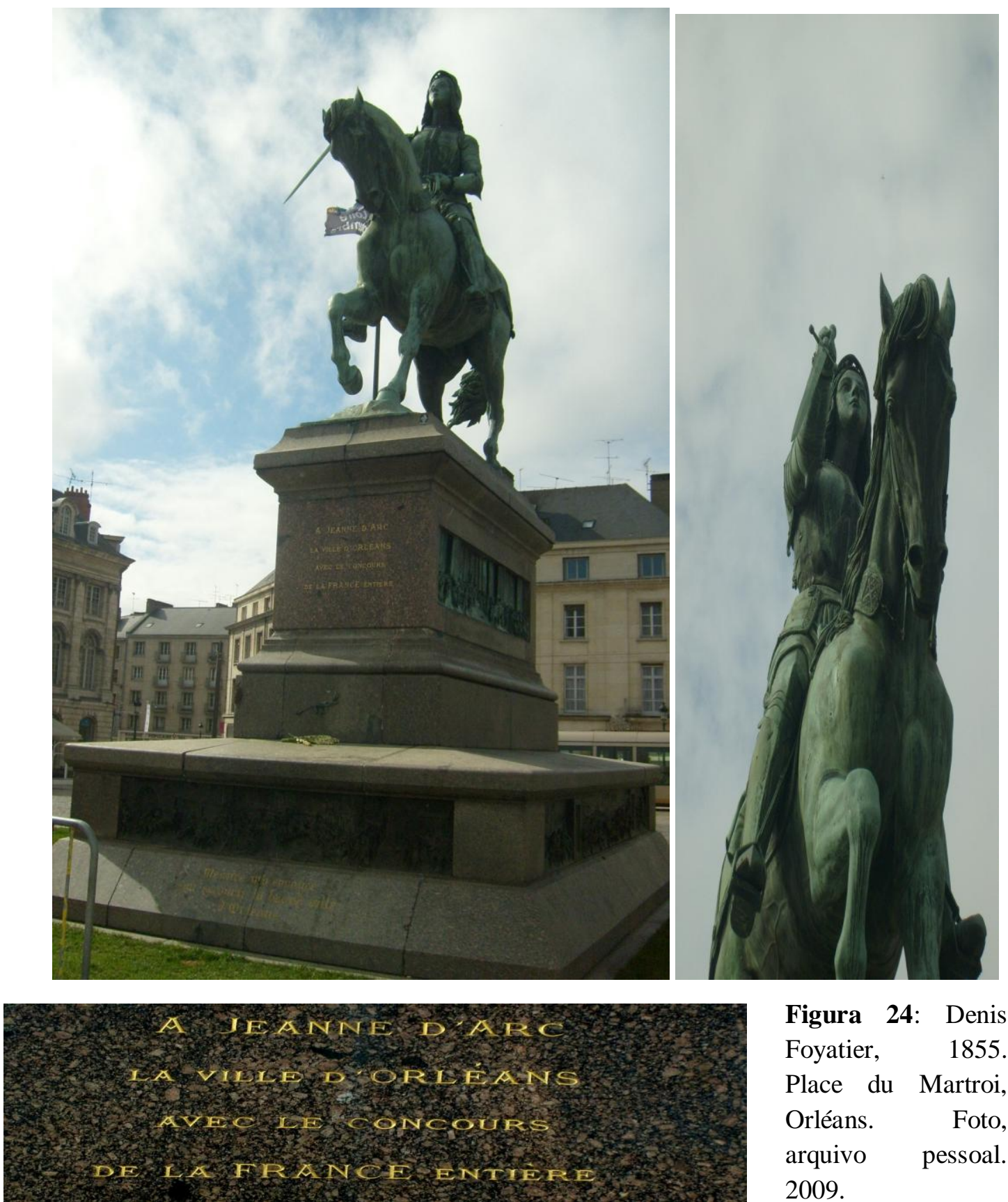

Figura 24: Denis

Foyatier, 1855.

Place du Martroi,

Orléans. Foto, arquivo pessoal. 2009.

A construção de um povo e uma nação francesas, bem como a defesa de sua existência objetiva carecia de um discurso convincente. Como provar, além disso, que a história de Joana d'Arc tem elementos suficientes para exemplificar a essência e o potencial do povo francês? A História assume a responsabilidade. E é a partir de um discurso científico que essas verdades serão construídas. 


\section{Capítulo IV - A História científica e a "verdade" sobre Joana d'Arc}

Como vimos no primeiro capítulo dessa tese, grande parte dos historiadores que se dedicaram a escrever sobre Joana d'Arc o fizeram no momento da profissionalização da História que passa a ganhar espaço privilegiado no campo do conhecimento almejando o status de ciência. Nesse contexto, destacou-se a edição dos processos de condenação e de anulação da condenação da Donzela realizada por Jules Quicherat, entre 1841 e 1850. Pela primeira vez esses documentos têm sua publicação integral, seguidos de três tomos dedicados a outras fontes concernentes à história de Joana, como crónicas e poesias.

De fato, a forma como essas fontes foram editadas há mais de 150 anos não trazem estranhamento ao pesquisador de hoje. Isso significa que as regras de erudição seguidas fazem parte de uma tradição da qual somos herdeiros. Mas qual seria a dívida da historiografia joânica com a suposta originalidade da História Científica no século XIX? Nesse capítulo pretendemos verificar em que medida o nascimento da pesquisa histórica moderna sobre Joana d'Arc está atrelado a esse processo e à constituição do campo histórico como produtor de verdades convenientes às demandas do período em questão.

\section{1 - A "Edição Quicherat"}

A história da publicação dos processos de Joana d'Arc tem por si só dados importantes para nossa reflexão. Não seria Jules Quicherat o responsável pela edição, mas como tudo indicava o alemão Guido Görres. Ele havia publicado no ano de $1834 \mathrm{em}$ Ratisbonne a obra Die Geschichte der Jungfrau von Orleans nach den Prozessakten und 
gleichzeitigen Croniken, baseada na maioria das fontes até então conhecidas a respeito de Joana d'Arc. A Sociedade de História da França havia reconhecido a importância de sua pesquisa:

\begin{abstract}
"Nós duvidamos que o zelo do erudito alemão deixe muito a fazer àqueles que vierem depois dele. M. Görres deu-se à bela missão de fazer um retrato acabado de Joana d'Arc, e não mediu esforços para encontrar até os traços mais sutis dessa grande figura. Após uma peregrinação histórica aos lugares que viram nascer a Donzela, àqueles que foram sucessivamente o teatro de sua glória, de seus sofrimentos e de sua morte, M. Görres dedicou-se ardentemente a examinar os grandes depósitos literários que poderiam lhe fornecer material para o monumento que prepara. Ele próprio já visitou os arquivos dos duques de Bourgogne em Dijon, as bibliotecas de Orleans, Tours, Angers, Mans, Chartres, Rouen, e finalmente a Biblioteca Real de Paris, e o sábio doutor se mostra disposto a seguir com o mesmo zelo suas longínquas e laboriosas pesquisas enquanto conservar a esperança em adicionar a menor novidade à imponente massa de documentos que ele já recolheu." 239
\end{abstract}

Nas atas das sessões seguintes da Societé, porém, fica cada vez mais claro o interesse pela publicação do processo de anulação da condenação de Joana d'Arc o qual não era contemplado na obra de Guido Görres. Além disso, chega-se à conclusão de que mesmo que Görres tivesse publicado tão completo material, seria importante à glória nacional proceder à edição dos dois processos em conjunto, pois para os membros da instituição, um era o complemento necessário do outro. Tratava-se também de um não declarado patriotismo, perceptível na crença da necessidade de ser a Sociedade de História da França o órgão responsável pela publicação de todas as fontes concernentes à história de Joana d'Arc, uma vez que a instituição havia sido criada para publicar os documentos originais relativos à História Nacional francesa. Por que permitir que um

\footnotetext{
${ }^{239}$ Bulletin de Ia Societé de l'Histoire de France, ano 1840, p. 12. Tradução nossa.
} 
alemão recebesse o reconhecimento por um trabalho que caberia à França realizar? Dessa forma, na sessão de seis de abril de 1840, Jules Quicherat, ex-aluno de Jules Michelet e formado pela École de Chartres, é escolhido como editor científico da futura publicação.

Quicherat recebe instruções em relação aos manuscritos a serem consultados, sendo que a ênfase é dada ao processo de anulação, que para a Societé era mais importante do que o de condenação. A fonte que anulava a condenação de Joana devia, na opinião daquela instituição, sua originalidade e merecia maior interesse do historiador devido ao grande número de depoimentos vindos de pessoas que estiveram com Joana d'Arc nas mais variadas épocas de sua vida. Dessa forma esse processo revelaria maiores detalhes da Donzela. A orientação é também que se publique, em seguida, "todos os textos originais contemporâneos relativos à Donzela, e próprios para esclarecer os testemunhos conservados nas peças justificativas dos dois processos". Por outro lado, deveriam ser descartados
"essa multidão de escritos de controversa teológica, de memórias consultivas que foram então publicadas pelos doutores de diferentes países, seja para apoiar as reclamações da família de Joana d'Arc, seja para fortificar a consciência indecisa do rei Charles VII, ou para esclarecer e encorajar os juizes e preparar a opinião pública para receber uma invalidação do julgamento da Igreja pela própria Igreja". ${ }^{240}$

Escolhas e métodos definidos, Quicherat se lança ao trabalho. Os processos são editados em três volumes e as demais fontes são assim separadas: no tomo IV estão as Crônicas e historiadores do XV e no tomo V os Poetas do XV.

A documentação do Processo de Condenação é constituída das atas que 
compunham o processo, desde a causae expositio et praeparatoria até as actae posterii, dos anexos que estruturaram a argumentação da acusação e dos interrogatórios dos meses de fevereiro e março, além de outras questões levantadas contra Joana nos meses de abril e maio de 1431. Até o dia 27 de março parte das acusações tinha sido enviada aos doutores da Universidade de Paris que redigiram uma ata contendo as 70 principais causas de culpa da ré. Após a análise de toda a documentação, em 2 de abril os doutores de Paris responderam às questões dos juizes e produziram uma versão condensada das acusações, que ficou conhecida como "Os 12 artigos".

Já a edição do Processo de Reabilitação ${ }^{241}$ apresenta os preliminares, não incluídos no processo original, mas analisados e publicados por Quicherat, e o processo propriamente dito desde os pedidos da família de Joana para sua realização até os depoimentos de mais de 120 testemunhas.

A folha de rosto da publicação enfatiza a originalidade da obra: "Publicados pela primeira vez a partir dos manuscritos da Biblioteca Real, seguidos dos documentos históricos que puderam ser reunidos e acompanhados de notas e esclarecimentos por Jules Quicherat.”

\footnotetext{
${ }^{241}$ A palavra "reabilitação" para se referir a esse processo foi utilizada pela primeira vez por Quicherat. Nos manuscritos mais antigos encontramos os termos "revisão", "anulação", "justificação" e até mesmo "absolvição". Cf. DUPARC, Pierre. "Le troisième procès de Jeanne d'Arc". In: Comptes-rendus des séances de l'Académie des Inscriptions et Belles-Lettres, 122e année, N. 1, 1978. pp. 28-41.
} 


\title{
PROCÈS
}

DE CONDAMNATION ET DE RÉHABILITATION

\author{
DE \\ JEANNE D'ARC \\ DITE \\ LA PUCELLE

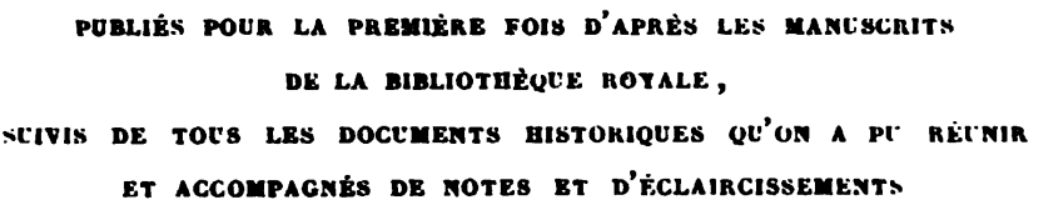

Par JULES QUicherat.

Figura 25: Folha de rosto da edição dos Processos de Condenação e Reabilitação de Joana d'Arc.QUICHERAT, op. cit.

Havia toda uma burocracia para se publicar em nome e pela Societé. Como vimos, tudo tinha de passar pelo crivo do conselho, que deveria propor as publicações e designar as pessoas mais aptas para isso. Trata-se do desejo dessa instituição de firmar-se como autoridade reconhecida a respeito do que deveria ser dito sobre o passado da França. Seria como um selo de procedência que garantia a confiabilidade do conteúdo da obra que tinha que ser "digna de ser publicada pela sociedade." Essa intenção era exposta na primeira página de todas as obras publicadas pela Societé que reproduzia o artigo 14 de seu regimento interno: ${ }^{242}$

\footnotetext{
242 "O Conselho designa as obras a serem publicadas e escolhe as pessoas mais capazes para preparar e acompanhar a publicação. Ele nomeia, para cada obra a ser publicada, um comissário responsável, encarregado de supervisionar a execução. O nome do editor será colocado à frente de
} 


\begin{abstract}
Art. 14. Le Conseil désigne les ouvrages à publier, et choisit les personnes les plus capables d'en préparer et d'en suivre la publication.

Il nomme, pour chaque ouvrage à publier, un Commissaire responsable, chargé d'en surveiller l'exécution.

Le nom de l'Editeur sera placé à la tête de chaque volume.

Aucun volume ne pourra paraitre sous le nom de la Société sans l'autorisation du Conseil, et s'il n'est accompagné d'une déclaration du Commissaire responsable, portant que le travail lui a paru mériter d'être publié.
\end{abstract}

\begin{abstract}
Le Commissaire responsable soussigné déclare que le travail de M. Jules Quicherat-sur les Prociss de Condamnation et de Rḱbabilitation de Jeanne i'Arc, lui a paru digne d'étre publié par la Sociḱtí de r'Historke de France.
\end{abstract}

Faic d̀ Paris, le 1 er aont 1841.

\title{
Signé JOLLOIS.
}

Figura 26: artigo 14 do regimento interno da Sociedade de História da França. In: QUICHERAT, op. cit.

Essas obras eram ainda agraciadas pelo selo de garantia:

cada volume. Nenhum volume poderá aparecer sob o nome da Sociedade sem a autorização do Conselho e se não for acompanhado de uma declaração do comissário responsável, dizendo que o trabalho lhe pareceu merecer ser publicado. O Comissário responsável abaixo assinado declara que o trabalho do M. Jules Quicherat sobre o Processo de Condenação e de Reabilitação de Joana d'Arc lhe pareceu digno de ser publicado pela Sociedade de História da França." Tradução nossa. 


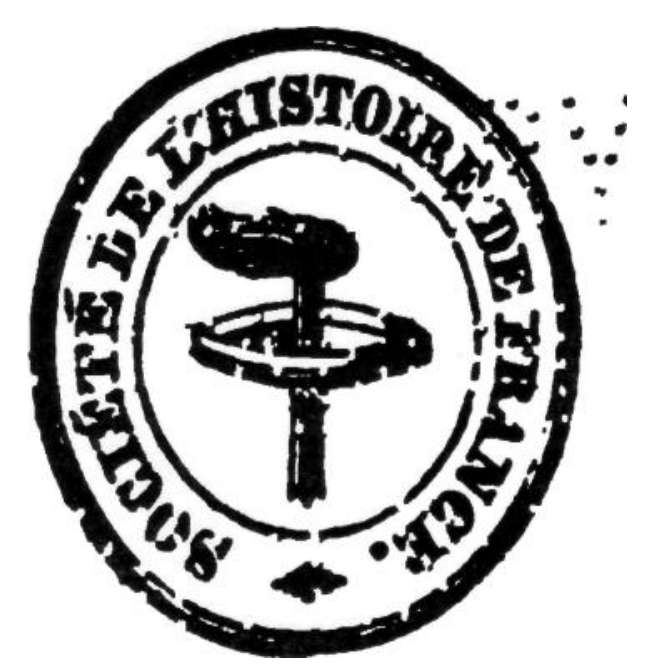

Figura 27: Selo da Sociedade de História da França.

De fato, Quicherat submete a uma revisão criteriosa as publicações anteriores a respeito dos processos de Joana d'Arc. Na obra de 1'Averdy ${ }^{243}$ ele aponta erros de datação, nomes, locais, sem deixar de reconhecer seu esforço para encontrar documentos que comprovassem questões apontadas no processo. No entanto, como não pôde suprir todas as lacunas, 1'Averdy chegou a algumas conclusões que Quicherat considerou imaginárias.

Além disso, Quicherat estabelece comparações entre os processos e fontes contemporâneas para precisar lugares e questionar alguns mitos em relação à história de Joana como, por exemplo, o de que todos os participantes de seu processo de condenação morreram de forma trágica ou tiveram destinos funestos. Suas notas de pé de página servem para apresentar não apenas sua visão sobre os fatos, como também as divergências entre as crônicas, informações sobre o contexto histórico, análises filológicas, etc. Essa

\footnotetext{
${ }^{243}$ Memorial lu au comité des manuscrits concernant la recherche à faire des minutes originales des différentes affaires qui ont eu lieu par rapport à Jeanne d'Arc, appelée communément la Pucelle d'Orléans de 1787 e o Notices et extraits des manuscrits de Ia Bibliothèque du roi, lus au comité établi par sa Majesté dans 1'Académie royale des Inscriptions et Belles Lettres de 1790.
} 
seria a melhor forma, em sua opinião, de manifestar seu intenso amor pela verdade, conforme ele afirma na introdução de Aperçus nouveaux sur l'histoire de Jeanne d'Arc, obra dedicada a relatar sua experiência de pesquisa com os processos da Donzela:

"É para expor essas percepções que empenhei todo meu estudo sem visar nenhuma outra coisa: nem o interesse de uma narrativa contínua, nem o apego ao lado dramático das situações. Já que não tenho como objetivo emocionar, mas somente fazer refletir, serei recompensado segundo o que desejo, se for encontrado nesse escrito alguma oportunidade de reflexão e um reflexo do amor infinito que

tenho

pela

verdade. ${ }^{, 244}$

Nessa obra ele tem a oportunidade de se posicionar diante de várias questões que giram em torno da história de Joana d'Arc. A respeito da polêmica em relação à missão da Donzela, Quicherat acredita que não foi pela perda de suas convicções que Joana começou a fracassar nas batalhas, mas pela falta de apoio da nobreza francesa. Para Quicherat, a Donzela tinha o projeto de tirar os ingleses de toda a França. "Assim se consumou o primeiro revés da Donzela não por sua culpa, nem pelo abandono da fortuna ou a diminuição de sua inspiração, mas pelas manobras daqueles em proveito dos quais ela realizou tantos milagres." 245

Outra polêmica discutida por Quicherat refere-se às vozes dos santos ouvidas por Joana d'Arc. Para ele não há solução para determinar se a Donzela realmente as escutava. Sua contribuição seria apenas apresentar da forma mais precisa possível as "particularidades da vida de Joana que parecem sair do círculo das faculdades humanas" ${ }^{246}$. Ele pretendia, portanto, guiar-se pela neutralidade baseando-se nos dados apresentados pelos documentos.

\footnotetext{
${ }^{244}$ QUICHERAT, J. Aperçus nouveaux sur l'histoire de Jeanne d'Arc. Paris, 1850.p. II. Tradução nossa.

${ }^{245}$ Idem, p. 35. Tradução nossa.

${ }^{246}$ Idem, p. 45. Tradução nossa.
} 
Apesar dos processos de Joana d'Arc nunca terem sido arrolados sem nenhum critério, com Quicherat temos pela primeira vez a edição completa de ambos, a partir da confrontação de todos os manuscritos, além da publicação de crônicas e poesias contemporâneas a ela em um esforço até então desconhecido por disponibilizar o maior número de fontes em relação à Donzela. Além disso, sabemos que a publicação ao trazer à tona detalhes mais precisos da aparência de Joana d'Arc, como o fato de se vestir como homem e possuir penteado masculino, teve grande impacto na iconografia joânica a partir de então ${ }^{247}$. Mas como apreendermos o verdadeiro significado da publicação? Trata-se de uma ruptura com uma tradição anterior, ou a expressão de esforços semelhantes há muito iniciados? Até que ponto pode ser mensurada uma originalidade? Seria o seu método tão inovador a ponto de trazer uma visão mais científica, mais neutra para a história de Joana d'Arc?

\section{2 - O século XIX e a originalidade da História Científica}

Muito da originalidade da visão histórica oitocentista e da profissionalização da área são atribuídas à influência das pesquisas de Leopold von Ranke, que a partir de seus critérios e métodos de investigação teria fundado uma verdadeira escola historiográfica. De acordo com essa perspectiva a partir da linguagem histórica seria possível pôr ordem ao caos do mundo moderno, dando-lhe inteligibilidade. Além disso, Ranke teria inaugurado o prazer em lidar com os documentos primários levando a uma verdadeira glamurização dos arquivos.

No entanto,

${ }^{247}$ HEIMANN, Nora M. "The art of politics in early nineteenth century France: E.-É.-F. Gois's Jeanne d'Arc pendant le combat as a metaphor". In: Gazette des Beaux-Arts. Tome CXXXII - 1554-55e livraisons. 1998. PP. 29-45. 
"Uma pesquisa recente mostrou que muitas das técnicas críticas utilizadas por Ranke - comparação sistemática de todas as fontes para um dado acontecimento, identificação das que foram produzidas mais proximamente a ele ou se apoiaram em documentação oficial, eliminação de fontes posteriores cujas informações são herdadas - surgiram na Renascença." 248

É a esse respeito que Anthony Grafton discute em As origens trágicas da erudição.

Segundo o autor a combinação de narrativa e reflexão provavelmente estabeleceu-se na historiografia muito antes da aurora do século XIX - ou de Ranke. Gibbon posteriormente teria unido a ironia e perspectiva ampla dos filósofos à erudição rigorosa dos antiquários a qual esses filósofos costumavam ridicularizar. "Muito antes de Ranke ou de Gibbon, nascera a história crítica - o tipo de história na qual o autor se angustiava com um engano de poucos meses na cronologia, assim como a atribuição de motivos e a identificação de causas" 249 .

Dentro dessa perspectiva é possível encontrar tal rigor ainda antes. Os antiquários dos séculos XVI e XVII liam e comparavam os textos, pesavam e mediam moedas antigas. “Outros reconstruíam a história da Europa Medieval, editando e avaliando crônicas e começando a sondar as profundezas dos arquivos nacionais e locais. ${ }^{250}$ Mas essa não teria sido sua única contribuição, uma vez que também foram responsáveis pela coleta, avaliação e análise desses manuscritos. Na opinião de Grafton

"Gibbon e seus colegas puderam, desse modo, apoiar-se em modelos de crítica de fontes e de citação de fontes obtidos de uma tradição de erudição secular que remontava à Renascença e até mesmo a épocas anteriores. (...) As compilações de fontes dos historiadores eclesiásticos e antiquários seculares forneceram a matéria-prima que os historiadores iluministas serraram, trabalharam e poliram; (...) contudo, os antiquários não forneceram nada semelhante a um modelo literário acabado para

\footnotetext{
${ }^{248}$ GRAFTON, Anthony. As origens trágicas da erudição. Campinas: Papirus, 1998.P. 72

${ }^{249}$ Idem, p. 121.

${ }^{250}$ Idem, p. 147.
} 
seus sucessores seculares."251

A questão que diferenciava, portanto, o trabalho erudito anterior da produção historiográfica moderna, seria exatamente a criação de um discurso, de uma linguagem que, ao mesmo tempo, possuía um sentido e criava um valor para o passado enquanto forma de leitura e compreensão da realidade humana. Além desse ponto fundamental, o contexto da criação da identidade nacional, no qual o papel da História é também o de justificar e reconhecer a origem de um determinado povo, levou à adoção de uma conduta apaixonada à medida que a identificação com o passado se consolidava:

"Gibbon e Möser, Robertson e Wolf repetiram em narrativas longas as estruturas que Bayle havia construído em pequena escala em cada verbete, lembrando as orientações de Leclerc para usuários de compilações eruditas. Ranke teve apenas dois ingredientes a acrescentar - porém ambos foram decisivos. Ele dramatizou o processo de pesquisa e de crítica, fazendo da nota de rodapé e do apêndice crítico uma fonte de prazer, mais do que uma ocasião para apologia. Os eruditos escrupulosos dos séculos XVII e XVIII criaram muitos aspectos da moderna prática histórica. Porém, raramente anteciparam o entusiasmo de Ranke, sua habilidade em terminar o dia na poeira de registros abandonados ainda excitado diante da aventura da descoberta e da interpretação. (...) Ranke, (...), tornou a pesquisa e a crítica glamurosas e dramáticas." 252

Na opinião de Grafton encontra-se nesse aspecto a principal diferença entre Ranke e seus antecessores. Se não podemos afirmar que foi o século XIX o responsável pela criação das regras de erudição e dos critérios meticulosos de pesquisa, devemos reconhecer o esforço dos oitocentistas para, a partir disso, desenvolver uma forma literária que unisse os dois pontos do empreendimento historiográfico: a pesquisa e a elaboração de um discurso coerente e explicativo a partir dela. Dessa forma chegaríamos à "fórmula" da

\footnotetext{
${ }^{251}$ Idem, p. 150; 155.

${ }^{252}$ Idem, p. 183, 184.
} 
História Moderna uma "mistura indispensável e confusa de arte e ciência." 253

Em relação à historiografia joânica a questão das regras de erudição aplicadas às fontes, sobretudo aos processos, sempre foi notável. Desde a anulação da condenação da Donzela o esforço para se conservar os manuscritos e o cuidado para analisá-los, identificar os personagens e lugares sempre foi enorme, apesar das frequentes incorreções.

Obras fundadas nos processos ou tentativas de edições são frequentes desde o século XVII. Entre 1625 et 1630, Edmond Richer, doutor da Universidade de Paris escreve Histoire de Ia Pucelle d'Orléans, minuciosamente baseada nos processos. No século XVIII temos os esforços de Lenglet-Dufresnoy com a obra Histoire de Jeanne d'Arc, vierge, héroine et martyre d'Êtat, suscitée par Ia Providence pour rétablir la monarchie française, tirée dês procès et autres pièces originales du temps, que deram origem a três volumes publicados entre 1753 e 1754 . Após três décadas ocorre, como já vimos, a publicação dos trabalhos de M. de l'Averdy. No século XIX, obras importantes baseadas nos processos, algumas por nós analisadas, como as de Berriat Saint-Prix e Lebrun des Charmettes antecedem a "Edição Quicherat". Charmettes, por exemplo, concede ao processo de condenação o status de "testemunha ocular" do evento ao escrever uma história de Joana d'Arc "a partir de suas próprias palavras" ${ }^{254}$, como vimos no capítulo 2 dessa tese. Caberia, portanto questionar: em que consiste a originalidade da obra de Quicherat?

\section{3 - A construção de uma verdade nacional e política}

Os processos de Joana d'Arc sempre foram, como vimos, fontes privilegiadas de

\footnotetext{
${ }^{253}$ Idem, p. 188.

${ }^{254}$ Histoire de Jeanne d'Arc, surnommée la Pucelle d'Orléans, tirée de ses propres déclarations, de cent quarante-quatre dépositions de témoins oculaires, et des manuscrits de la Bibliothèque du Roi et de la Tour de Londres.
} 
sua história, mesmo antes da edição crítica de Quicherat entre 1841 e 1850. Quicherat, porém, assume o lugar do discurso da verdade que a História reivindica com sua profissionalização e essa definição passava pela negação da tradição anterior bem como pela necessidade em assumir uma postura diferenciada através dos signos da ciência.

Conforme a análise de Ph. Contamine,

"no total, mesmo de forma precipitada, imperfeita, fragmentada, numerosos textos, antes de 1840, já haviam sido relatados, analisados, editados, publicados, o que permitiu por três ou quatro vezes a redação das histórias de Joana d'Arc às quais faltavam sem dúvida a nossos olhos, perspectiva e fôlego, mas que eram incontestavelmente detalhadas e documentadas. "255

O discurso corrente na primeira metade do século XIX de que aquele momento representava uma ruptura em relação aos mais variados aspectos do Antigo Regime fez com que alguns historiadores do passado fossem menosprezados e até ignorados mesmo pelos estudiosos mais criteriosos como Quicherat. Sua indiferença em relação a alguns de seus antecessores deveu-se à sua preocupação com o conteúdo monarquista e a defesa do absolutismo presente em algumas dessas obras como foi frequente no período da Restauração. Dessa forma ele deixa de valorizar e reconhecer muito do espírito crítico presente nas obras que o precederam. Le Brun des Charmetes, por exemplo, se enfurece com erros de dias na cronologia, mas foi desqualificado por ser monarquista. Não devemos nos esquecer, no entanto, de que eles forneceram material para que Quicherat fizesse suas escolhas, ressignificando esse trabalho. Além disso, através de sua preocupação com o tema do entusiasmo os antecessores de Quicherat foram responsáveis pela identificação de Joana d'Arc com o povo e a nação, estabelecendo-a definitivamente

\footnotetext{
${ }^{255}$ CONTAMINE, Ph. "Jules Quicherat historien de Jeanne d'Arc". In: Bulletin de l'association des Amis du Centre Jeanne d'Arc, n 14, 1990, p. 7-19. P. 8. Tradução nossa.
} 
como heroína nacional. Se há uma Joana d'Arc, digamos "laicizada”' a qual Quicherat consegue identificar sem apelo às emoções, como ele próprio afirma, ele deve muito a essa historiografia joânica anterior e a seus trabalhos que lhe ofereceram material para uma postura científica em relação ao tema.

Na opinião de P. Garcia, a reação científica da História foi a admissão de uma nova postura dos historiadores mediante a incapacidade da historiografia anterior, dita romântica, em criar um espaço propriamente científico, uma demarcação entre opinião e prova - um espaço profissional. Assim essa mudança de perspectiva teria se concretizado através da

$$
\begin{aligned}
& \text { "pretensão de uma cientificidade para o conhecimento } \\
& \text { histórico com a emergência da figura do historiador, a } \\
& \text { formação de uma comunidade científica de historiadores, a } \\
& \text { entrada da História para o rol das disciplinas } \\
& \text { universitárias, a construção de um método e um sistema de } \\
& \text { regras específicas para a produção do saber historiográfico } \\
& \text { e a emergência dos primeiros paradigmas historiográficos } \\
& \text { - o Positivismo e o Historicismo." 256 }
\end{aligned}
$$

Mas será que a busca por uma postura científica se trata tão somente, como afirma Garcia, de uma reação à influência da paixão política na História, observada por ele na postura dos historiadores das décadas de 20 e 30 do século XIX? Em nossa opinião essa paixão pelas questões políticas não abandona a História ainda que ela tenha se tornado “mais científica". O que se pode perceber, por exemplo na "Edição Quicherat", é a busca por uma postura científica, sendo a Societé um órgão capaz de autenticar o que seria digno ou não de confiança em relação às fontes. O passado torna-se um alvo de investigação que teria no campo científico as pessoas autorizadas para falar a seu respeito. A questão de crítica às fontes, no entanto, vem de uma tradição. Quicherat é herdeiro não só dessa tradição, como de L'Averdy e de outros monarquistas da Restauração.

${ }^{256}$ BARROS, José d'Assunção. Teoria da História. Vol. II. Os primeiros paradigmas: o positivismo e o historicismo. Petrópolis: Vozes, 2011. p. 24. 
Finalmente há a construção de um campo investigativo a partir do qual se pode falar em nome da ciência: qual era a verdade sobre Joana d'Arc? Isso, porém, não significa que estivessem livres de paixões.

No fundo percebemos uma restrita "liberdade científica" para os trabalhos de Quicherat, já que ele estava engajado no projeto de uma instituição que estava a serviço de outra: a Societé a serviço do Estado Francês. O descarte de certos documentos está baseado em uma suposta pouca importância para a compreensão da história de Joana d'Arc, na ideia de que para encontrar a verdade sobre a heroína francesa aqueles documentos não contribuiriam. Trata-se da produção de uma verdade, supostamente neutra, que dá a ideia de imparcialidade e amor desinteressado pela ciência, mas feita através de escolhas, nem sempre objetivas, que visam decidir o que merece ou não ser pesquisado de acordo com o interesse da Sociedade de História da França em relação à própria história de Joana d'Arc.

\section{4 - A História Científica a serviço da Nação}

Patrick Geary afirma que a constituição da disciplina histórica enquanto científica deu-se, sobretudo, dentro da gestação das ideias nacionalistas e dos projetos políticos que se lhe seguiram. François Dosse, ao falar da sobreposição da consciência nacional e discurso historiográfico no século XIX francês, lembra que:

"A precocidade da constituição de um Estado-Nação, confrontada com 0 caráter radical da ruptura revolucionária de 1789, constitui o húmus sobre o qual essa autoridade [da história] pôde ser exercida. A nação pôde então beneficiar-se de uma verdadeira transferência 
de sacralidade, e o historiador encarregou-se de enraizar o sentimento nacional da população."257

Naquele momento, o período medieval serviu como base para definição das origens dos povos, o que foi usado para estabelecer direitos e justificar uma série de processos de dominação e disputas ao longo dos séculos XIX e XX. Os estudos históricos e arqueológicos do período serviam para atestar um momento de "aquisição primária"258 que teria estabelecido limites originários, primordiais de um povo sobre determinado território. De acordo com tais estudos, todas as invasões e migrações posteriores seriam ilegítimas.

A obra de Kostas Vlassopoulos, Unthinking the Greek polis ${ }^{259}$, mostra uma perspectiva interessante em que o autor remonta ao contexto historiográfico do século XIX no qual se forjou de forma eurocêntrica o conceito de polis, utilizado a partir de então como uma entidade política dada o que, de certa forma, ajudou a criar uma narrativa nacional homogeneizante. Seu livro aponta para uma direção atual das pesquisas históricas que é a de repensar como seus meios e métodos de análises foram constituídos e de que forma eles podem ter engessado determinadas visões sobre sociedades passadas.

O debate aqui proposto objetiva contribuir para a discussão não só da retomada da Idade Média como momento original, mas também para uma reflexão sobre a própria História, sua constituição como campo atrelado a interesses políticos e sobre como devemos nos posicionar em relação ao conhecimento histórico cujos métodos foram criados, como lembra Geary, em uma "paisagem envenenada".

${ }^{257}$ DOSSE, F. A História à prova do tempo. Da história em migalhas ao resgate do sentido. São Paulo: Unesp, 2001. p. 11.

258 “(...) o século I para os alemães, o século V para os francos, os séculos VI e VII para os croatas, os séculos IX e X para os húngaros e assim por diante.”GEARY, P. op. cit. P. 23.

${ }^{259}$ VLASSOPOULOS, K. Unthinking the Greek polis. Ancient Greek History beyond Eurocentrism. Cambridge University Press, 2007. 
"A história moderna nasceu no século XIX, concebida e desenvolvida como um instrumento do nacionalismo europeu. Sendo assim, a história das nações européias foi um grande sucesso, mas transformou nossa compreensão do passado em um depósito de lixo tóxico impregnado do veneno do nacionalismo étnico, que penetrou fundo na consciência popular. A limpeza desse lixo é o mais intimidante dos desafios enfrentados atualmente pelos historiadores. $" 260$

Geary continua esse raciocínio fazendo a seguinte advertência:

“as próprias ferramentas de análise com a qual temos a pretensão de praticar a história científica foram inventadas e aperfeiçoadas em um ambiente mais amplo de inquietações nacionalistas. Os métodos modernos de pesquisa e escrita da história não são instrumentos neutros da academia, mas ferramentas desenvolvidas especificamente para favorecer os propósitos nacionalistas." 261

Nesse contexto, em especial no caso francês, espera-se da História uma pacificação do passado nacional. A ciência é chamada para definir o que é a França, o que e quem é o povo. A História Científica deve também definir quem é Joana d'Arc.

No caso de Quicherat, vemos que estava totalmente comprometido com o projeto do estado nacional em que pese toda sua originalidade. Por isso o autor é parte da consolidação de um processo que vem da necessidade de se ressignificar o passado da França, sendo o testemunho da forma como esse discurso alcançou o status de verdade.

Quando esclarece sua opinião acerca do problema da missão de Joana d'Arc, Quicherat demonstra de que forma a ciência poderia estar a serviço da construção da nação. Na parte V dos Aperçus o autor começa dando o testemunho da Chronique de la Pucelle, o único documento em que a Donzela aparece falando que já tinha cumprido sua

\footnotetext{
${ }^{260}$ GEARY, P. op. cit. p. 28.

${ }^{261}$ Idem.
} 
missão após a coroação do rei e que desejava voltar à casa de seus pais.

Para Quicherat trata-se de uma interpolação a partir do depoimento de Dunois no processo de anulação, quando ele relata uma conversa com Joana em que ela diz que não sabe onde e como vai morrer e que gostaria de voltar à sua região e ajudar seus pais seus irmãos.

A partir da análise de vários documentos o autor afirma que a missão de Joana ficou pela metade. Usa depoimentos, crônicas e até uma obra em versos, o Ditié de Jeanne d'Arc de Christine de Pisan, para provar que seu objetivo era tirar todos os ingleses da França e libertar o duque de Orléans. Não foi pelo abandono da fortuna nem a diminuição de sua inspiração, que seus desejos não se realizaram, mas pelas manobras políticas. Dessa forma o apelo à literacidade do documento presta ao objetivo de consolidar a imagem de Joana d'Arc como inquestionável heroína nacional uma vez que as questões que a impulsionavam tinham origens políticas e visavam a expulsão de um povo estrangeiro da pátria francesa.

O questionamento do discurso de ruptura, do qual Quicherat é um dos grandes expoentes, nos permitiria afirmar que mesmo sem a Revolução Francesa teria surgido a História Científica? O exemplo de 1'Averdy mostra que a capacidade de erudição, de crítica às fontes se pronunciava com destaque. A última geração do século XVIII contou com mais de um tipo de historiografia assistindo à convivência entre colecionadores eruditos de textos e críticos iconoclastas com historiadores filosóficos, ambas fontes nas quais beberam os historiadores científicos.

"A moderna historiografia científica nasce, portanto, deste entremeado bastante complexo, tecido e entretecido a partir de pequenas e grandes coisas: das esperanças e utopias iluministas às decepções e pessimismos românticos, das técnicas de crítica documental desenvolvidas pelos filólogos da Igreja com vistas a desmascarar uns aos outros ao emblemático tempo retilíneo do 
cristianismo por vezes já secularizado pela filosofia neoclássica; do desejo de encontrar a unidade da natureza humana ao encantamento diante da extrema diversidade de todos os homens."262

Mas se essa Historia Ciência se configura como discurso de uma burguesia que busca no passado nacional as raízes da legitimação do seu poder, a Revolução foi fundamental, uma vez que a necessidade desse discurso teve sua origem a partir das discussões do contexto pós-revolucionário. Houve uma mudança no grupo responsável pela união da reflexão à crítica dos eventos que saiu das mãos da nobreza, e passou às mãos dos que verdadeiramente eram capazes de compreender o que significavam aqueles testemunhos do passado, nas palavras de Thierry, "somos os únicos a entender o passado". Tudo isso, como vimos, passa pela definição de quem era o povo e do que era a França.

Estamos em um período no qual a questão da santidade de Joana d' Arc ainda não tinha sido aventada com grande fôlego. À parte algumas menções anteriores ${ }^{263}$, nunca havia sido feita uma tentativa sistemática para a canonização de Joana d' Arc, o que só vai ocorrer na segunda metade do século XIX. O sucesso desse processo a médio prazo deve-se ao trabalho dos historiadores anteriores que, ao sedimentar seu heroísmo articulando-o principalmente em torno do entusiasmo e sua relação com as ações coletivas na construção da liberdade civil, pôde fazer com que Joana d' Arc se tornasse cada vez mais torna alvo de projeções coletivas.

Ao mesmo tempo, a edição dos processos tornou acessível a muitas pessoas

\footnotetext{
${ }^{262}$ BARROS, José d'Assunção. op. cit. p. 16-17.

263 No século XVII, o dia 30 de maio, data da morte de Joana d'Arc, aparece no Martyrologium gallicarum como dia do martírio da Donzela. Em La Pucelle ou la France delivreé , também do século XVII, Chapelain usa o epíteto "santa" para se referir à Joana d'Arc em 87 dos 218 versos de sua obra. Em apenas três versos ele a qualifica como heroína. Cfr. MICHAUD-FRÉJAVILLE, F. "Personne, personnage, Jeanne d'Arc en France au XVII ${ }^{\mathrm{e}}$ siècle", dans D. Goy-Blanquet (sous la direction de), Jeanne d'Arc en garde à vue, Bruxelles, 1999, p. 55-77.
} 
documentos confiáveis sobre a história de Joana a partir dos quais puderam ser criadas outras verdades a respeito da Donzela. Esse foi o caminho trilhado na segunda metade do século XIX pela Igreja Católica francesa que, no século seguinte, conseguiu fazer de Joana não apenas santa como também a segunda padroeira da França. Ao estabelecer que a verdade dependia da consulta aos processos, a História Científica abre um campo de possibilidades para que o processo de ressignificação de Joana d' Arc estivesse ao alcance de diferentes grupos que passam a se referir à Donzela de acordo com seus propósitos específicos.

A busca pela verdade atrelada à análise dos processos leva a uma hierarquização dessas fontes que são comparadas em função de sua suposta proximidade com a realidade dos fatos. Alguns autores assinalam uma preferência pelo processo de condenação uma vez que nele Joana responde com suas próprias palavras - ela está inteira e verdadeiramente nas fontes. Outros, ao defenderem a proeminência do processo de anulação da condenação, afirmam que o número de testemunhos acerca da vida de Joana e o fato de terem sido pessoas que conviveram com a Donzela em momentos distintos garantem uma maior veracidade das informações, já que, enquanto ré no processo que a condenou, Joana estava acuada. A recusa e desconfiança em relação ao processo de condenação também estão ligados ao fato da fonte ser considerada uma vergonha jurídica, sendo seus erros e desvios uma verdadeira afronta mesmo à tão criticada justiça medieval e inquisitorial. A sensação de que através dos processos estamos mais próximos da verdadeira Donzela de Orléans jamais abandonou a historiografia joânica. A Societé há muito postulou que mesmo as crônicas, fontes literárias e outros documentos a respeito de Joana serviriam para esclarecer pontos obscuros dos processos. A instituição exigiu que só deveriam ser publicados naquela oportunidade os documentos "próprios para esclarecer os 
testemunhos conservados nas peças justificativas dos dois processos". O último congresso internacional dedicado exclusivamente à Joana d'Arc ${ }^{264}$ mostra, pelo título escolhido e nas diferentes abordagens e discussões acerca dos processos de Joana, que essa verdade em relação à Donzela a qual essas fontes supostamente dão acesso é reconstruída a cada geração e não deixou de ser o fio condutor das pesquisas joânicas até o momento.

Uma visão de História apropriada de formas cada vez mais diversificadas. As interpretações a respeito da história de Joana d'Arc sofrem ainda a influência da projeção de princípios das instituições modernas para o passado, em nosso caso o medieval, período condenado por confundir as instituições políticas e religiosas. A realidade da divisão dos poderes, da necessidade da criação do estado laico, todas discussões fundamentais na agenda política oitocentista francesa são projetados ao passado, são projetados à epopeia de Joana d'Arc.

Nos Aperçus Quicherat ressalta as questões fundamentalmente políticas por trás das ações de Joana d'Arc. Ele analisa uma fonte alemã que compara Joana às sibilas que faziam previsões em prol do seu país. Quicherat tenta precisar a especificidade de Joana em relação a outras profetizas e visionárias: suas visões eram apenas em relação à França e seu alcance de curto prazo. Outra questão que Quicherat observa é que, retirada sua aura mística, as previsões de Joana aproximam-se mais a estratégias ligadas à questão política. Se suas visões nos impressionam é porque nos lembramos apenas das que deram certo, mas, como o autor lembra, muitas profecias não se concretizaram:

“Observando a natureza de suas previsões, a razão poderá ver apenas eventos anunciados por um gênio que, sem admitir, tinha em si a forma de produzi-los. Aliviadas de sua expressão mística, elas se tornavam efetivamente prognósticos políticos ou de estratégia, como fizeram o tempo todo os homens de Estado superiores e os grandes

264 "De herética à Santa - os processos de Joana d'Arc revisitados". Centro Cultural Internacional de Cerisy-la-Salle, outubro de 2009. 
capitães. Se elas se apresentam na história com um caráter de infalibilidade que ultrapassa a medida humana é porque só se registrou aquelas que aconteceram; mas conforme demonstrei anteriormente, Joana previu coisas que não aconteceram, daí se conclui que o maravilhoso de seu instinto profético é corrigido pela diversidade de seus efeitos." 265

A forma como Quicherat se posiciona em relação ao tema das vozes também merece destaque. Ao analisar essa questão tão polêmica o autor se apega às próprias fontes, ou seja, aos depoimentos de Joana e ao processo de anulação, sobretudo. A partir das fontes ele descreve como elas se manifestavam: através de vozes, luzes, visões. Quicherat percebe nas respostas de Joana a respeito das vozes uma tentativa de escapar das más intenções dos juizes no que diz respeito à aparência e/ou atributos dos santos. O autor diz que Joana se esforçava para fazer com que eles se parecessem com as imagens já cristalizadas desses santos, e que em algumas ocasiões ela tinha dificuldade em descrever alguns de seus atributos. Ele ainda afirma que os testemunhos são vagos e insuficientes para classificar Joana em algum caso patológico.

“Teólogos, psicólogos, físiologistas, não tenho solução a lhes indicar: que eles encontrem se puderem, cada um com seu ponto de vista, os elementos de uma apreciação que desafia toda contradição. A única coisa de que me sinto capaz de fazer na direção em que se exercerá uma semelhante pesquisa, é de apresentar sob a forma mais precisa as particularidades da vida de Joana que parecem sair do círculo das faculdades humanas."

Quando Quicherat conclui que a perda de convicção não foi responsável pelas derrotas de Joana d'Arc ele rompe com a tradição que atribuía suas ações ao entusiasmo. A partir dessa objeção à tendência anterior, da forma como ele abandona a ideia de que foi uma força interna a responsável pelo sucesso das batalhas de Joana d'Arc, Quicherat inaugura

\footnotetext{
${ }^{265}$ QUICHERAT, J. Aperçus... p. 75.

${ }^{266}$ Idem, p. 45.
} 
uma postura que se cristaliza na análise dos processos. Não cabe ao historiador julgar se a Donzela ouvia ou não as vozes dos santos. Mas ainda assim é possível perceber que foi o processo de ressignificação do entusiasmo, ao identificá-la com o povo, ao laicizar seu comportamento, que abriu essa possibilidade de ruptura. Quicheat viu motivações e manobras políticas por trás de toda a história de Joana d'Arc. A explicação vai em direção ao contexto para estabelecer uma racionalidade na compreensão daqueles eventos. O autor explica a missão de Joana d'Arc como fruto de uma infância marcada pela presença da guerra e pelo nascimento do sentimento de revanche contra um inimigo que assolava a região em que nasceu:

"A partir do dia em que o inimigo leva ao vale a morte e o incêndio, sua inspiração foi iluminando tudo que havia nela de piedade e religião pelo seu solo natal. Sensibilizada pelos sofrimentos dos homens no espetáculo da guerra, confirmada na lei de que uma justa causa deve ser defendida às custas de todos os sacrifícios, ela conheceu seu dever". ${ }^{267}$

A forma religiosa seria apenas uma linguagem para expressar as motivações políticas. A História Científica politiza ainda mais a história de Joana d'Arc e Quicherat define o que seria objeto da historiografia excluindo, por exemplo, a possibilidade de se saber sobre a questão das vozes. Delega-se esse assunto para a via religiosa que vai percorrer o caminho da canonização na segunda metade do século XIX, curiosamente a partir dos mesmos documentos editados por Quicherat.

$\overline{{ }^{267} \text { QUICHERAT, J. Aperçus... p. } 9}$ - 10. 


\section{CONCLUSÃO}

De persona a personagem(s)

Nosso trabalho procurou demonstrar o caminho intelectual percorrido pela historiografia francesa na primeira metade do século XIX para enquadrar Joana d'Arc, heroína há muito honrada pelo reino da França, nos padrões da sociedade pósrevolucionária. Longe de desqualificá-la como figura incompatível com a modernidade pretendida por aquele país, tal como proposto no contexto revolucionário, Joana foi alçada ao panteão dos heróis nacionais tendo sua imagem amalgamada aos ideais de 1789. Buscamos desvendar o processo que tornou possível a popularização e mesmo a universalização de uma nova Joana d'Arc naquele período, processo intimamente ligado aos valores burgueses então difundidos: a nação, o povo, a pátria, o indivíduo. Não por acaso sua aproximação de temas da literatura romântica, que naquele momento se configurava como expressão artística do novo grupo social que ascendia ao poder. As novas características atribuídas à Joana correspondiam às expectativas burguesas a partir de um discurso ligado a uma nova visão da História que passou a ser considerada como potencial produtora de verdades e justificativas que embasassem a configuração social que se anunciava.

Nesse contexto, ao encontrarem a Donzela de Orléans nos documentos disponíveis, os autores escreviam a história de sua vida, intimamente atrelada aos acontecimentos que definiram a sorte da França na Guerra dos Cem Anos. Fizeram-no na esteira de uma tradição biográfica a qual marcou profundamente suas obras superando, ao mesmo tempo, o papel que esse gênero ocupava no contexto literário de então. Victor Cousin havia comentado com desdém que a biografia e as memórias tratavam adequadamente dos aspectos superficiais da personalidade, e que seria 
responsabilidade da Historia e da Filosofia tratar dos temas gerais. Portanto, para ele, a verdade e o propósito da História não poderiam ser expressos por um gênero que tratava dos detalhes, do que era apenas aparente. Os biógrafos de Joana d'Arc ultrapassaram esse obstáculo, esforçando-se para relacionar cada aspecto de sua vida aos mais gerais e universalizantes ideais. Mas não se deve ao acaso ou aos seus esforços localizados o sucesso de tal empreitada. Para que houvesse a possibilidade de tal associação foi necessária uma mudança que tocasse a própria noção de indivíduo na sua relação com o todo, modificação essa que segundo a historiadora Françoise Michaud-Fréjaville ${ }^{268}$ já havia afetado a imagem da Donzela ainda no século XVII.

Em artigo no qual aborda a forma como os autores se referem à Joana d'Arc no Antigo Regime, a autora observa que há uma mudança de suas atribuições, que inicialmente estavam relacionadas a um modelo arquetípico, das mulheres virtuosas, das heroínas bíblicas ou gregas, indo em direção a uma maior historicização dos eventos de sua vida, o que fez com que ela fosse vista como um personagem, um ser humano de características individualizadas. "Está claro que (...) no período clássico Joana torna-se universalmente um personagem, não era mais uma persona."269

A preocupação com o seu "eu" interior passa a existir com mais clareza e isso se reflete na atenção progressiva direcionada ao tema das vozes, que passam a ser associadas a uma disposição do espírito - o entusiasmo - apelando para a ideia de consciência do sujeito. Procuramos discutir ao longo desse trabalho como o tema do entusiasmo é fundamental para compreender o significado de Joana d'Arc para a

\footnotetext{
${ }^{268}$ MICHAUD-FRÉJAVILLE, Françoise. "Personne, personnage: Jeanne d'Arc en France au XVIIe siècle." In : Jeanne d'Arc en garde à vue, sous la direction de Dominique Goy-Blanquet, Bruxelles, 1999, p. 55-77. p. 64.

${ }^{269}$ Idem, p. 64.
} 
sociedade francesa pós-revolucionária. No entanto, não se trata do entusiasmo tal como visto pelo século XVIII, nossa tese é a de que esse atributo da personalidade de Joana passou por um fundamental processo de ressignificação, que teve como produto a associação definitiva de Joana d'Arc às demandas do Terceiro Estado. Victor Cousin havia sinalizado com lucidez a via que lhe parecia percorrer a sociedade francesa oitocentista: "O século XVIII foi a era do criticismo e das destruições; o século XIX deve ser a era das reabilitações inteligentes." ${ }^{270}$ Vimos que esse processo de longo alcance na sociedade francesa, não se limitou à figura de Joana e teve início tão logo se anunciaram os primeiros arroubos iconoclastas da Revolução, tendo se mostrado com clareza na Era Napoleônica.

Conforme analisamos no primeiro capítulo da tese, Napoleão Bonaparte cumpre papel importante no processo de ressignificação do passado. Ao analisar a fortuna da estátua de Gois Jeanne d'Arc pendant le combat, Nora Heimann lembra que a intervenção de Bonaparte foi fundamental para que fosse erguido o monumento feito para substituir a estátua da Donzela destruída pelos revolucionários em 1792. A autora nos ajuda a compreender de que forma essa obra contribui para o culto moderno de Joana d'Arc na França ${ }^{271}$. Heimann lembra que mais do que o período da Restauração foi a Era Napoleônica, incluindo a inauguração dessa estátua, a responsável por apresentar ao século XIX a nova Donzela de Orléans, afastando-a na medida do possível das associações anteriores de sua imagem à causa religiosa e monarquista, uma vez que o erguimento do monumento fora patrocinado pelo próprio Cônsul da República Francesa. Seu aspecto bélico é o que mais chama a atenção (figura 28), apesar de a

\footnotetext{
${ }^{270}$ COUSIN, Victor. Du vrai, du beau et du bien. Paris, Didier, 1881. P. 9

${ }^{271}$ HEIMANN, Nora. "The art of politics in Early Nineteenth Century France: E. -É. - F. Gois's Jeanne d'Arc pendant le combat as a metaphor." In: Gazette des Beaux-Arts. T. CXXXII - 1554-55e livraisons. 1998. P. 29-46.
} 
imagem ainda ser adornada pelo chapéu de penachos, alegoria cristalizada pelo retrato “dos Échevins” ainda no século XVII (Figura 2, Introdução).

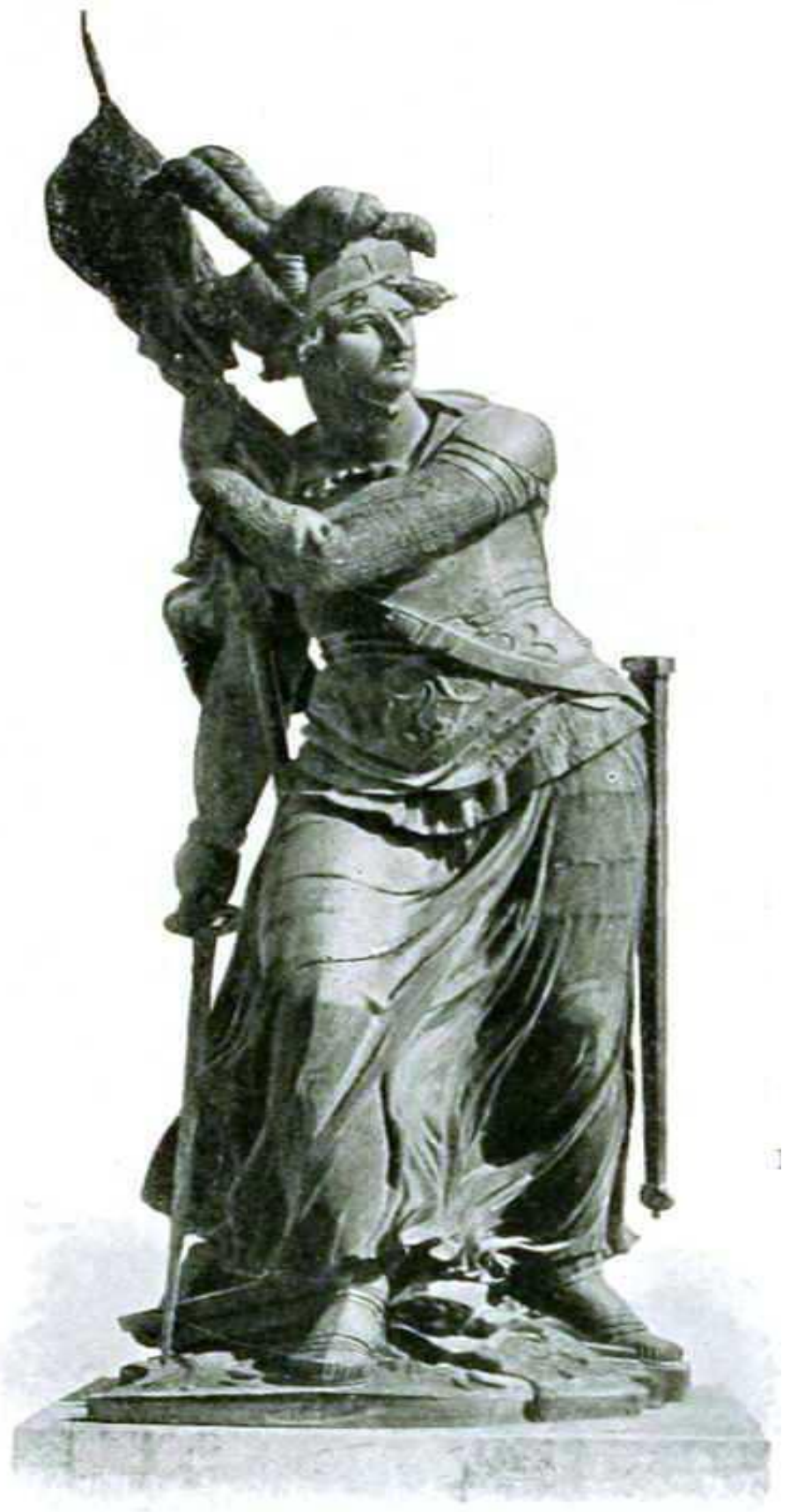

Figura 28: Jeanne d'Arc pendant le combat. Estátua de Gois, inaugurada em 1804. Disponível em:

http://education.environnement.ec oles.over-blog.com/45-categorie11565659.html Acesso: 18/04/12

Cunhou-se até mesmo uma medalha comemorativa pela inauguração da estátua em Orléans na qual temos de um lado o busto do Primeiro Cônsul e do outro a 
reprodução da obra de Gois cuja data de inauguração está marcada de acordo com a nova contagem do tempo iniciada pela Revolução: $\mathrm{XI}^{\mathrm{o}}$ ano da República:
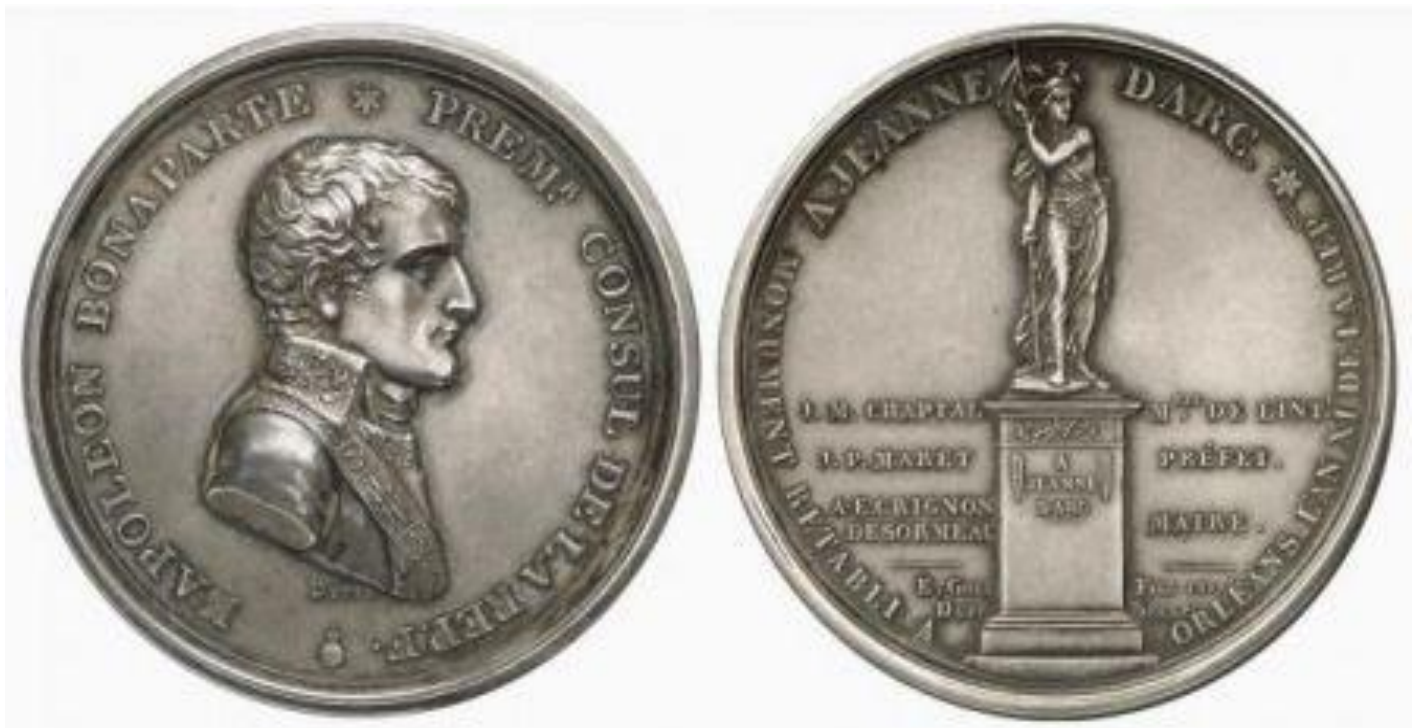

Figura 29: Medalha comemorativa pela inauguração do monumento de Gois, onde se lê: "Napoleão Bonaparte, Primeiro Cônsul da República Francesa; À Joana d'Arc, monumento restabelecido em Orléans, $\mathrm{XI}^{\mathrm{o}}$ Ano da República" disponível em: http://www.medaillesjeannedarc.fr/index.php?/page/6 acesso em 18/04/12

A argumentação de Heimann vai além. Ela diz que Joana seria a heroína perfeita para Napoleão uma vez que sua associação à belicosidade e à defesa dos ideais da pátria poderiam ser usados para suscitar tais valores nos franceses sem a necessidade de apelar à figura de Marianne, a alegoria francesa popularizada no contexto da Revolução, imagem feminina que aparece usando o gorro frígio, símbolo republicano e revolucionário por excelência. O aspecto radical de Marianne seria dessa forma evitado e substituído pela imagem guerreira de Joana d'Arc tão libertária quanto, porém menos associada ao perigoso radicalismo revolucionário ${ }^{272}$.

\footnotetext{
${ }^{272}$ Yan Rigolet chama a atenção para a associação entre Joana d'Arc e Marianne no período revolucionário: “(...) a heroína suscitou o interesse dos revolucionários, ao mesmo tempo como símbolo da libertação e resistência, assim como modelo possível da alegoria da Liberdade que se tornará nossa Marianne nacional." RIGOLET, Yann. "De la messagère de Dieu à Marianne". In: Religions \& Histoire $n^{\circ} 25$, 2009. Page: 51-53. Tradução nossa.
} 


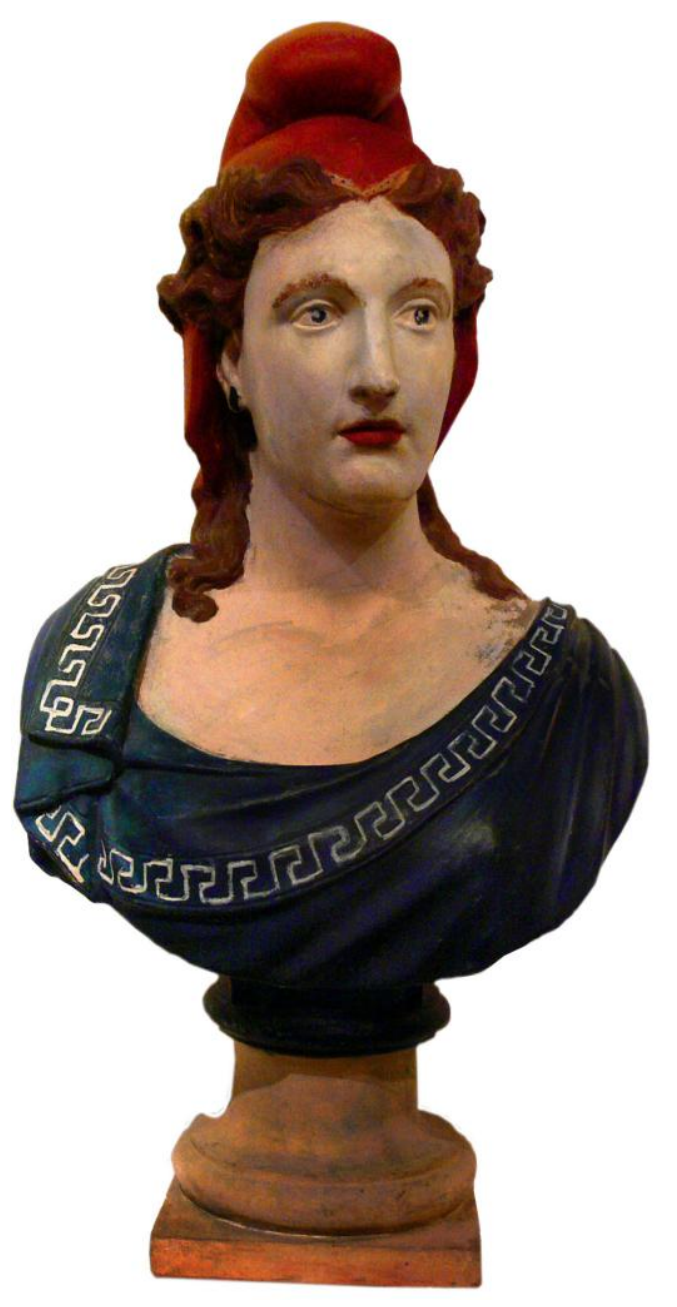

Figura 30 - Busto de Marianne, representação simbólica da República Francesa. (anônimo) Exposta no Senado em Paris. Foto de F. Lamiot 2006. 


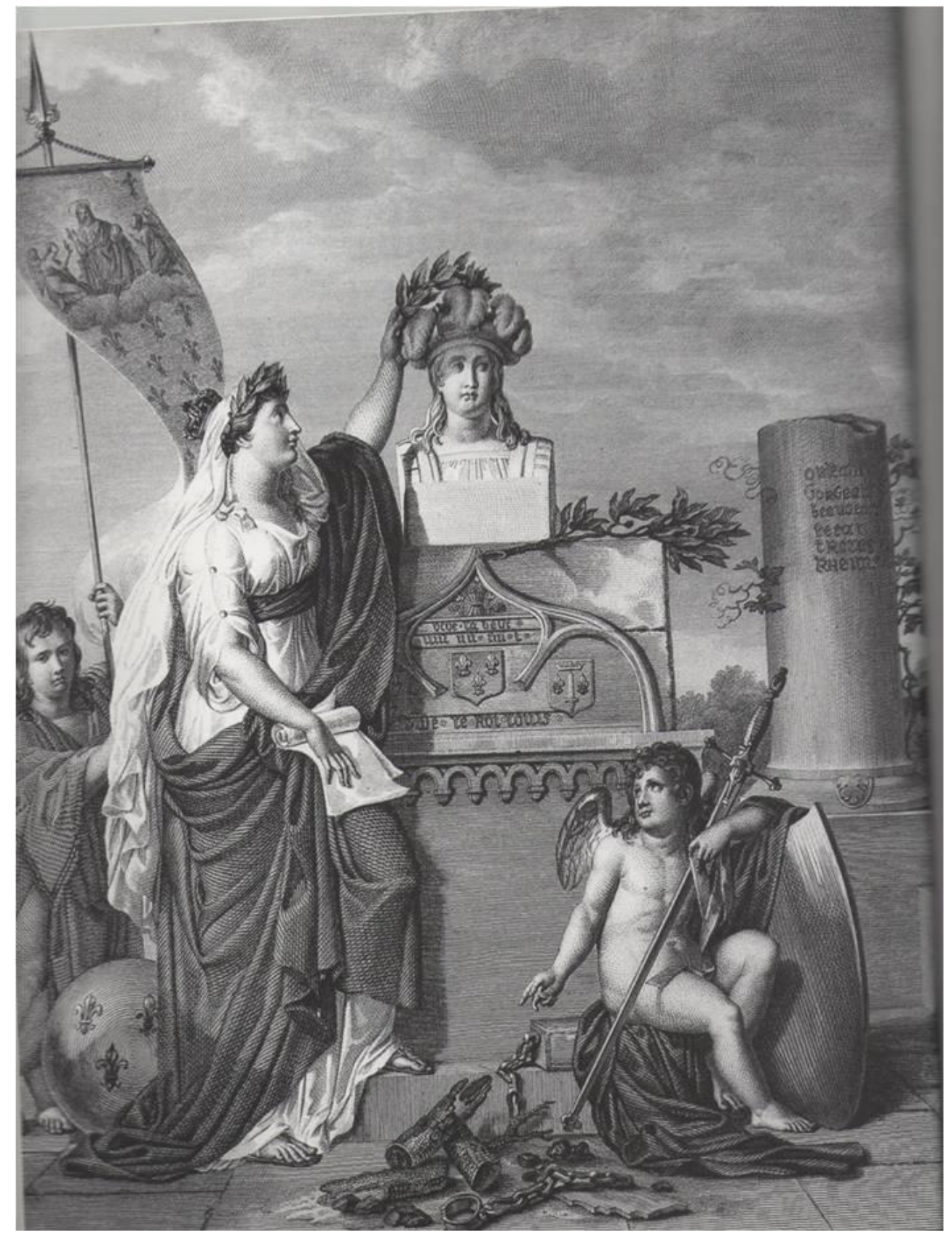

Figura 31 - "Busto de Joana d'Arc coroado pela França" - 1830. Desenho de Lafitte.(Centre Jeanne d'Arc, inv. 74.12.2649) 
A associação de Bonaparte à renovação do culto à Joana por meio do erguimento da estátua de Gois é tanto mais convincente quanto nos damos conta de que o mesmo grupo que apoiava o governo napoleônico foi o responsável pelo patrocínio da obra. Os nomes de proprietários, advogados e grandes comerciantes figuram na lista dos doadores para a construção da estátua, nos levando a considerar a validade do argumento de que Napoleão Bonaparte foi uma peça-chave no processo de ressignificação do passado pelo qual passou a sociedade francesa após a Revolução. Os grupos sociais os quais apoiaram tanto o Golpe do 18 do Brumário, quanto o regime imperial estabelecido por Bonaparte eram exatamente os que viam a necessidade de frear o carro revolucionário garantindo os ganhos da burguesia e, ao mesmo tempo, combatendo a radicalização.

“(...) em menos de 16 meses desde a aparição da escultura de Gois na abertura do Salão de Belas Artes de 1802 em Paris, 'Jeanne d'Arc pendant le combat' foi celebrada como um monumento nacionalmente reconhecido, abençoado pelo bispo, festejado pelo prefeito, pago por Napoleão e pelo povo da França." 27

A argumentação da autora em defesa da importância da relação entre a estátua de Gois e o governo napoleônico vai ainda mais longe. Ela atribui a perda de interesse pela estátua e as críticas a ela dirigidas como fruto da queda de prestígio do período imperial, visto que tais críticas se dirigiam não só à estética propriamente dita da obra, ou melhor dizendo, as críticas associavam o monumento ao período napoleônico e tal relação parecia suficiente para rejeitar aquela imagem da Donzela. Eis a opinião de um anônimo na publicação do Jornal do Loiret em 1845: "Essa desagradável caricatura do Império, espécie de Murat de anáguas, esse esgrimista fêmea o qual nós temos o mal 
hábito de nomear 'A Donzela.' "274 Ao associar aquela aparência de Joana d'Arc a Murat, cunhado de Napoleão e peça fundamental do exército e das invasões do período imperial, a frase reflete ainda uma recusa ao aspecto masculino e violento da estátua; qualidades que, apesar de serem passíveis de identificação em grande parte do acervo iconográfico concernente à Joana d'Arc foram naquele momento oportunamente associados a uma manipulação por parte do império dos verdadeiros valores e da aparência da Donzela.

Trata-se apenas de um dos testemunhos dentre a avalanche de críticas que a obra sofreu. Esse processo culminou na sua substituição, primeiro por uma cópia da obra Jeanne d'Arc en prière (Figura 21, capítulo III) em 1837 e mais tarde, em 1853, pela estátua equestre que é o marco central da cidade de Orléans, localizada na Place $d u$ Martroi (Figura 24, capítulo III), não por acaso inaugurada por Napoleão III no exato momento em que, mais uma vez, o conservadorismo francês buscava a contenção de ideais políticos radicais que naquela ocasião eram expressos pelos objetivos sociais e políticos preconizados pela Revolução de 1848. Esse conservadorismo político a nosso ver foi o responsável pela ressignificação do passado em um contexto mais amplo e mais especificamente pelas novas atribuições associadas a Joana d'Arc no século XIX. Napoleão, a nosso ver, é um dos personagens mais emblemáticos desse processo. Ele tomou para si a responsabilidade de não permitir a destruição de uma certa tradição francesa vinda ainda dos tempos absolutistas. Tal decisão se expressa também tanto na restauração de Saint Denis, quanto em sua aproximação com a Igreja Católica, sinalizando que não era objetivo da França perder seu posto de "Filha mais velha da Igreja Católica.” A Concordata assinada com o Papa Pio VII em 1801, expressa não apenas esse desejo, mas também revela que essa relação deveria se estabelecer em ${ }^{274}$ APUD HEIMANN op. cit. p. 41. Tradução nossa. 
outras bases a partir das quais haveria uma aliança, mas de forma alguma uma submissão dessa filha que se tornara independente e soberana. Assim se atribui um novo significado à relação com a Igreja Católica passado e/ou submetido o desejo revolucionário de fazer "tábula" rasa do passado instituindo uma nova sociedade.

Não se trata de atribuir somente a Napoleão a responsabilidade pelo início e solidificação de um profundo e amplo processo como foi a ressignificação do passado. Mas Bonaparte expressa sem dúvida, em relação à Joana d'Arc e outros personagens e instituições, que agia em consonância com um movimento de conservação que mobilizava grande parte da sociedade francesa atingindo a área política, social e cultural, fenômeno que não passou desapercebido pela intelectualidade do período:

"A maioria dos Ideólogos que se interessavam pela História estavam intelectualmente e temperamentalmente em desacordo com a reavaliação da Idade Média que caracterizou o início do século dezenove; estavam igualmente em desacordo com a estética do Romantismo a qual em sua opinião expressava uma política cultural reacionária e intransigente." 275

Essa virada conservadora atingiu a intelectualidade no exato momento em que a História passa a ser vista, conforme já discutimos, como área do conhecimento oportuna para se pensar e justificar as estruturas e projetos da sociedade em questão. "A transformação do burguês em um revolucionário que lutou pela liberdade de todo o Terceiro Estado é, por sua vez, uma invenção burguesa, desenvolvida pelos historiadores da Restauração e, especialmente, por Guizot."276

\footnotetext{
${ }^{275}$ CROSSLEY, C. op. cit. p. 17. Tradução nossa.

${ }^{276}$ FONTANA, J. A história dos homens. Bauru: Edusc, 2004. P. 364.
} 
José d'Assunção Barros lembra que a História Moderna recebeu no século XIX uma dupla influência conservadora: do historicismo e do positivismo ${ }^{277}$. O historicismo alemão apresentava uma relação direta com a afirmação dos Estados Nacionais, prestando-se também, de inicio, a um discurso conservador. Nesse caso, não representaria exatamente os interesses de uma classe, mas dos grandes estados, da burocracia estatal que financiava seus projetos historiográficos. Por outro lado, a influência positivista no saber histórico traz uma reconfiguração conservadora da herança iluminista ao atacar os arroubos revolucionários que impediriam a descoberta das leis sociológicas que asseguram uma harmoniosa estabilidade social.

Assim, a primeira metade do século XIX era o momento para provar que uma ruptura radical não se sustentava na prática. As revoluções liberais são um reajuste às conquistas burguesas com a inclusão de concessões monárquicas. A História ganha muito espaço, como vimos, nesse contexto. O desejo em conhecer os antepassados na forma como se apresenta se apresenta a partir de então, é parte de um processo de reorganização do mundo de acordo com os projetos e aspirações da burguesia. Trata-se do momento do imperialismo, em que também nasce a Antropologia cujo foco passa a ser o conhecimento das populações a serem dominadas. Paralelamente a essa empreitada defende-se que o mesmo esforço deveria ter uma correspondência nos limites do Estado Nacional, conforme advoga Ranke:

"O que precisamos é de um homem equipado com um conhecimento razoável, cartas de recomendação pomposa e boa saúde, que cruzaria a Alemanha de ponta a ponta para caçar os restos deste mundo que está imerso e, no entanto, tão próximo de nós. Perseguimos pastos desconhecidos nos desertos da

\footnotetext{
${ }^{277}$ BARROS, José d'Assunção. Teoria da História. Vol. II. Os primeiros paradigmas: o positivismo e o historicismo. Petrópoles: Vozes, 2011.
} 
Líbia: não deveria a vida dos nossos antepassados, em nosso próprio país, merecer o mesmo entusiasmo?" 278

Em complemento a todo o processo anteriormente descrito, cabe uma última observação que nos permite compreender ainda mais as novas atribuições recebidas por Joana d'Arc no século XIX. Como vimos, Joana d'Arc deixa de ser um caso particular, localizado em Orléans e ligado a Carlos VII tornando-se um símbolo nacional e universal, o terceiro estado em busca da liberdade. Assim há um deslocamento dos fatores religiosos de sua missão, realizado pela laicização trazida pela ideia de entusiasmo, o que só é possível quando se analisa o período medieval com a intenção de se separar as esferas política e religiosa.

Sem dúvida para compreender a ressignificação da imagem de Joana d'Arc no século XIX temos de levar em conta o quanto a proposição de uma sociedade constituída de esferas que não deveriam se cruzar, como Religião e Estado, discussão fundamental no período em questão, foi definitiva nesse processo. A separação dessas esferas projetada ao período medieval trouxe consequências analíticas substanciais, algumas das quais abordadas por Alain Guerreau ${ }^{279}$. Nesse artigo o autor aponta para a impossibilidade de se dividir em diversos nichos de significação o que o homem medieval entendia como realidade. Quando ocorre uma discussão sobre a necessidade da divisão das várias esferas sociais para uma melhor organização da sociedade na modernidade ocidental, tais como a religiosa, a jurídica, a política e a econômica, há uma projeção dessa opção social para outras épocas e povos. No caso da história de Joana d'Arc os séculos XVIII e XIX vão proceder a essa interpretação para que Joana possa ser mantida como referência para os franceses. Tal projeção foi fundamental para

\footnotetext{
${ }^{278}$ RANKE, L. Zur Kritik. P. 181. apud GRAFTON, op. cit.

${ }^{279}$ GUERREAU, Alain. "Política / Derecho / Economía / Religión: ¿Cómo eliminar el obstáculo?” In: DE TOGNERY, Reyna Pastor (org.). Relaciones de poder, de producción y de parentesco en la Edad Media y Moderna: aproximación a su estudio. Madri: Consejo Superior de Investigaciones Científicas, 1990 p.459-465.
} 
que se pudesse dar uma interpretação singular ao entusiasmo de Joana d'Arc, que foi transformada em uma heroína, e apesar de sua história ser inseparável das questões de fé, laica. Autores como Sismondi e Michelet vão usar o entusiasmo para fazer essa separação que é própria da modernidade.

Também na obra de Quicherat é possível perceber a importância dessa projeção. Em sua opinião as respostas de Joana d'Arc no Processo de Condenação mostram uma mistura “(...) de religião e patriotismo que fermentava em seu pensamento infantil. Ela olhava a França como o reino de Jesus, e assim os inimigos desse santo reino eram para ela, os inimigos de Deus. ${ }^{280}$ Para o autor tratava-se de uma confusão, mas na verdade quem estabelece essa separação é a modernidade; no contexto em questão, tal diferenciação não faria algum sentido.

Quicherat denuncia que as acusações contra Joana tiveram origem em questões políticas no que aparentemente deveria ser um processo restrito à conduta religiosa da ré:

"A ata de acusação, em que somos tentados a acreditar que os elementos foram cuidadosamente colocados, alega apenas questões de significado político. Só se detém em propósitos maliciosos, obra de loucura e superstição, para estabelecer que Joana se dava desde a infância a práticas reprovadas pela fé. Só tenho como prova uma artigo em que se usa o tom de terror, para dizer que ela dependurava em certa árvore, próximo da vila, guirlandas de folhagem e flores que desapareciam durante a noite." 281

O processo de ressignificação da imagem de Joana d'Arc passou pela politização de sua trajetória ligando-a às questões políticas da França do XIX. Assim ela foi

\footnotetext{
${ }^{280}$ Idem, p. 3.

${ }^{281}$ QUICHERAT, J. Aperçus nouveaux... p. 4.
} 
associada ao Terceiro Estado que segundo o pensamento político liberal do período, foi o que mais sofreu pela mistura ou confusão entre as esferas política e religiosa.

De onde viria a necessidade de pontuar se os reais motivos de sua atuação tinham origem religiosa ou não uma vez que tal questão não se colocava em sua época? Como afirma Guerreau não se tratava de uma liberdade de escolha, já que não havia o entendimento moderno da opção por uma religião, mas a ideia de participação de uma comunidade de fieis na qual a defesa da fé e a defesa do Estado não se colocava de forma distinta.

Entendemos que até mesmo o processo que levou à canonização de Joana d'Arc é fruto dessa interpretação que projetava uma separação entre as esferas sociais para o período medieval, ao propor uma separação do que é santo (religião) e do que é político. Quando a historiografia aponta para essa heroína como "do povo", abre-se o caminho para que a Igreja Católica explorasse maiores detalhes de sua personalidade relacionando-os definitivamente à causa divina. Por outro lado, a politização de sua epopeia permitiu que a Igreja se livrasse da culpa por sua morte que passa a ser responsabilidade exclusiva, segundo o discurso católico, do clero inglês, que havia corrompido suas atribuições misturando questões políticas a um assunto da fé. Assim, a Igreja Católica pode eximir-se de tamanho erro, lançando-se de forma aberta e engajada na campanha pela canonização. Não por acaso essa campanha só ganha força na segunda metade do século XIX com os esforços do Monsenhor Félix Dupanloup, bispo de Orléans.

O caminho para a canonização só pôde ser percorrido quando foi possível associar a causa e a vida de Joana d'Arc unicamente ao propósito divino, posição que ganha cada vez mais espaço quando se constrói essa imagem em oposição a uma Joana 
laica e revolucionária, traída pelo rei e queimada pela Igreja. Tal oposição chega ao ápice no final do século XIX quando há uma luta protagonizada pelo deputado republicano Joseph Fabre por tornar a festa de Joana d'Arc um feriado nacional, celebrado de forma laica, sem apelos religiosos ${ }^{282}$. Ele consegue a aprovação da câmara em 1884, mas sua proposta não é aceita no Senado. Dez anos mais tarde a Igreja Católica responde a essa empreitada republicana com a ascensão de Joana d'Arc à condição de "Venerável", proclamada pelo Papa Leão XIII que ficou conhecido por marcar a posição da Igreja em relação a essa disputa ao proclamar: Johanna notra est.

A partir dessa distinção da modernidade houve a possibilidade de se construir uma imagem de Joana d'Arc que passa a ser associada a inúmeros valores e situações. Quanto mais núcleos identitários, de formas mais diversas Joana pode ser ressignificada. Com a valorização dos aspectos históricos, os particularismos são valorizados e cada item de sua personalidade pode ser explorado. Assim temos uma diversidade de "Joanas", várias personagens a serem associadas às mais diversas demandas sociais. Existe a Joana laica, a santa, a celta, a protestante, a feminista, a esquerdista, a de extrema direita, a druida, etc.

Por fim nosso trabalho buscou mostrar acima de tudo os cuidados a serem tomados com a ideia da construção de uma verdade histórica. A suposta neutralidade e imparcialidade de nossas pesquisas sofre, além das pressões dos meios acadêmicos e editorial, a influência daquilo que a sociedade imagina ser o compromisso do discurso histórico. Como negar que nosso campo de trabalho ainda seja visto por grande parte da sociedade e mesmo dos poderes instituídos como área de produção de verdades que tem

\footnotetext{
282 SANSON, R. "La fête de Jeanne d'Arc en 1894, controverse et célébration". Revue d'Histoire moderne et contemporaine, 20 (1973), p. 444-463.
} 
por objetivo criar identidades, valorizar grupos sociais, justificar suas demandas e até mesmo reparar injustiças do passado?

Além disso, o passado, matéria prima de nossas investigações, é usado como um terreno em que se podem encontrar as mais desvairadas justificativas para se cometer atrocidades. Anders Behring Breivik, de 33 anos, que se dizia "Comandante Chefe de Justiça dos Templários”, assassinou em julho de 2011, na cidade de Oslo, 72 pessoas em nome do que ele chamou de uma Cruzada em favor dos "direitos dos povos autóctones da Europa", segundo seu manifesto de 1700 páginas que disponibilizou na internet $^{283}$ e cujo símbolo é a Cruz Templária. (Figura 32). Ele espantosamente usa o título da obra de Bernardo de Claraval, escrita no século XII, como forma de mostrar que suas ideias fazem parte de uma tradição e se justificam pela gloriosa missão de combater os infiéis mulçumanos, conteúdo constante em seu Manifesto que conta com citações de outras autoridades como o próprio Heródoto.

\footnotetext{
${ }^{283}$ www.kevinislaughter.com/wp-content/uploads/2083+A+ European+Declaration+of+Independence.pdf
} Acesso em 26/04/12. 


\section{3}

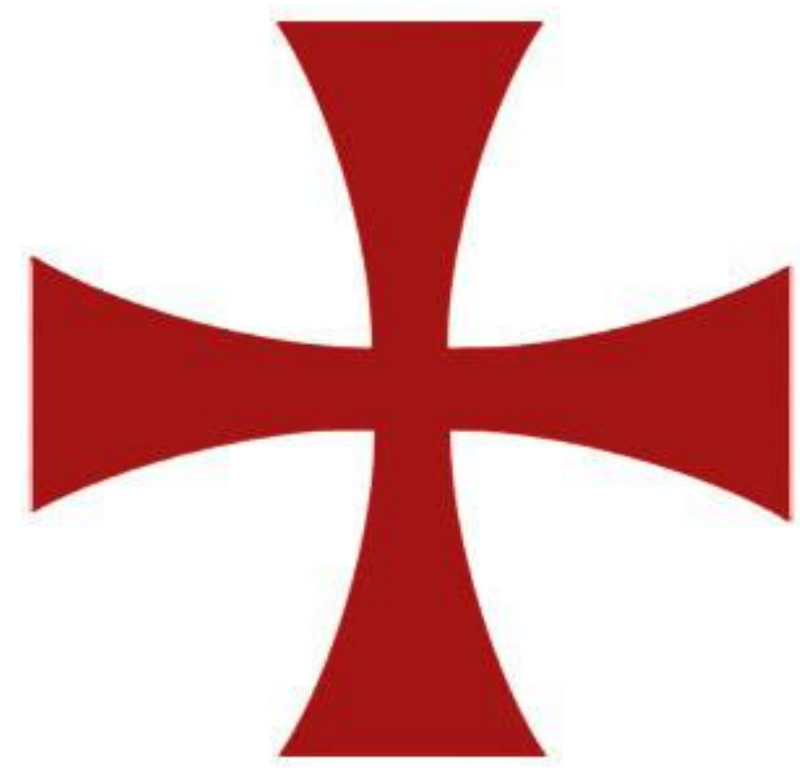

Figura 32: Primeira página do Manifesto "2083: A European Declaration of Independence" do terrorista norueguês Anders Behring Breivik. Disponível em:

\section{A European Declaration of Independence}

De Laude Novae Militiae

Pauperes commilitones Christi Templique Solomonici www.kevinislaughter.com/ wp-

content/uploads/2083+A+ European+Declaration+of+ Independence.pdf

Qual a responsabilidade do historiador na construção dessas verdades perigosas? A crença em uma história nacional ainda orienta certas pesquisas, como sabemos, fato que mesmo sendo válido como opção metodológica, deve ser alvo de constante reflexão pela forma como os princípios, métodos e objetivos dessa orientação historiográfica foram criados no passado.

É indispensável repensar os métodos históricos dos quais somos herdeiros e que foram gestados em uma "paisagem envenenada". Se essa tese teve o mérito de 
contribuir para a reflexão sobre nosso ofício e para repensar qual é o compromisso do historiador com a sociedade a partir do exemplo de Joana d'Arc tomo minha tarefa por cumprida. 


\section{REFERÊNCIAS BIBLIOGRÁFICAS}

Fontes Primárias:

BARANTE, P. "Jacques Bonhomme”. In: Mélanges historiques et littéraires II .1835.

BERRIAT SAINT-PRIX. Jeanne d'Arc ou coup d'oeil sur le revolutions de France au temps de Charles VI et Charles VII et surtout de la Pucelle d'Orléans. À Paris, Chez Pillet, imprimeur-libraire; Éditeur de la collection des moeurs françaises, 1817.

CHAMPION, Pierre. Procés de condamnation de Jeanne d'Arc. Texte, traducion et notes de Pierre Champion. Paris : Honoré Champion, 1920.

DUFRESNOY, Nicolas Lenglet. Histoire de Jeanne d'Arc, dite la Pucelle d'Orleans, vierge, hérö̈ne et martyre d'état: suscitée par la providence pour rétablir la monarchie française, Paris: Coutellier, 1753-1754.

GUILLERMIN (abeé). Choix de panégyriques et plans de discours de plus célèbres orateurs contemporains en l'honneur de la vénérable Jeanne d'Arc. Paris, 1895.

GUIZOT, François. Cours de Histoire Moderne. Paris: Pichon et Didier, 1828.

. Histoire de la civilization en France. Paris, 1856.

GRÉGOIRE. Rapport sur les inscriptions des monuments publics. 22 Nivôse an II. (10/01/1794.) Disponível em: http://gallica.bnf.fr/ark:/12148/bpt6k484940/f3.image.

HUME, David. Essays Moral, Political, and Literary (1742-1754) ESSAY X: OF SUPERSTITION AND ENTHUSIASM. On line: http://www.english.upenn.edu/ mgamer/Etexts/hume.superstition.html acesso em março de 2011.

The History of England from the Invasion of Julius Caesar to the Revolution in 1688, Foreword by William B. Todd, 6 vols. (Indianapolis: Liberty Fund 1983). Vol. 2. Chapter: XX: HENRY VI. Accessed from http://oll.libertyfund.org/title/789/67294 on 2010-10-25. 
L'AVERDY, C. Mémorial lu au comité des manuscrits concernant la recherche à faire des minutes originales des différentes affaires qui ont eu lieu par rapport à Jeanne d'Arc, appelée communément la Pucelle d'Orléans. Paris, Imprimerie Royale, 1787.

- Notices et extraits des manuscrits de la Bibliothèque du roi, lus au comité établi par sa Majesté dans l'Académie royale des Inscriptions et Belles Lettres. Paris, Imprimerie Royale, 1790.

LEBRUN DES CHARMETTES. Epîtres politiques sur nos extravagances. Paris, 1831.

Histoire de Jeanne d'Arc, surnommée la Pucelle

d'Orléans, tirée de ses propres déclarations, de cent quarante-quatre dépositions de témoins oculaires, et des manuscrits de la Bibliothèque du roi et de la la Tour de Londres. 4 volumes. Á Paris, chez Arthur Bertrand, Libraire, Rue Hautefeuilie, n. 23. 1819.

MICHELET, Jules. Histoire de France . Anot. de Charles Marc des Granges. Paris: Hatier, 1946.

Histoire de la Révolution française. Gallimard, 1952.

. Jeanne d'Arc. Avec une introd. et un répertoire explicatif des notes de Michelet par Émile Bourgeois. Paris : Librairie Hachette. 1909.

. Oeuvres Complétes. 1832-1839. Flammarion, 1996.

O Povo. São Paulo: Martins Fontes, 1988.

. "Sur l'histoire des Français de Sismondi". In:

Ouevres

Completes. Flammarion, 1996.

Journal d'un Bourgeois de Paris à la fin de la Guerre de Cent Ans. Editado por Colette Beaune. Paris, 1990. 
PETITOT. Mémoires concernant la Pucelle d'Orléans, dans lesquels se trouvent plusieurs particularités du régne de Charles VII. Paris, 1819.

PISAN, C. Ditié de Jehanne d'Arc. Ed. Angus J. Kennedy and KennethVarty.Oxford : Society for the Study of Mediaeval Languages and Literature, 1977.

QUICHERAT, Jules. Aperçus nouveaux sur l'histoire de Jeanne d'Arc. : Paris: Jules Renouard 1850. . Mélanges d'archeologie et d'histoire. 2 t. Paris, 1885

Procès de condamnation et de réhabilitation de Jeanne d'Arc, dite la Pucelle, publiés pour la première fois d'après les manucrits de la Bibliothèque nationale, suivis de tous les documents historiques qu'on a pu réunir, et accompagnés de notes et d'éclaircissements; 5 vol. in- $8^{\circ}$, 1841-1849. Paris, chez Jules Renouard.

SISMONDI, Sismonde. Histoire des Français. T. 13. Paris, 1821.

THIERRY, Augustin. "Histoire véritable de Jacques Bonhomme d'aprés les documents autentiques". In: . Oeuvres completes. T. 3. Paris, 1851.

Paris, 1852. Lettres sur l'histoire de France. Dix ans d'études historiques. Ouevres complétes. Paris: Garnier: 1867. Récit des temps mérovingiens. Delort Robert: Paris, 1981.

Livros e artigos:

AGULHON, Maurice. "La statuomanie et l'histoire”. In: Ethnologie française, 1978.

ALLEN, John Smith. "Toward a social history of French Romanticism: authors, readers and the Book Trade in Paris". 1820-1840. In: Journal of Social History. 1979. 253-276. 
AMALVI, Christian. Le goût du Moyen Âge. Paris: La Boutique de L'Histoire, 2002.

L'image d'Étienne Marcel dans l'historiographie du XIXe siécle.

Thèse. Paris. École de Chartes, 1983. Manuscrit.

ANDERSON, Benedict. Comunidades imaginadas: reflexiones sobre el origen y la difusion del nacionalismo. Mexico : Fondo de Cultura Economica, 1993.

AULARD, Alphonse. "Émules et prédécesseurs du pére Loriquet”. In: Révolution Française. 77. 1924. P. 5-44.

Le patriotisme français de la Renaissance à la Révolution. Paris, 1921.

BARROS, José d'Assunção. Teoria da História. Vol. II. Os primeiros paradigmas: o positivismo e o historicismo. Petrópoles: Vozes, 2011.

BARTHES, Roland. Michelet. São Paulo: Companhia das Letras, 1991.

BARZUN, Jacques. "Romantic historiography as a political force in France". In: Journal of the History of ideas. 2. 1941. P. 318-329.

BAUCHY, Jacques-Henry. Une fête pas comme les autres. Orléans, 1979.

BEAUNE, Colette. Joana d'Arc. Trad. Marcos Flamínio Peres. São Paulo: Globo, 2006.

BERTIER DE SAUVIGNY, Guillaume. La restauration. Paris, 1963.

BELL, David A. The Cult of the Nation in France: Inventing Nationalism, 1680-1800. Cambridge, MA: Harvard University Press, 2001. 
BEURET. Canonisation de Jeanne d'Arc. Charleville, 1855.

BORDAS, Éric. "De l'historicisation des discours romanesques»". Revue d'histoire du XIXe siècle, 2002-25, Le temps et les historiens. [En ligne], mis en ligne le 29 juin 2005. URL : http://rh19.revues.org/document420.html. Consulté le 17 octobre 2008.

BORMAN, Frank. "Michelet et les metamorphoses du Christ". In: Revue d'histoire de la France. 1974. p. 824-851.

BOSTOCK, J. Knight. "The Maid of Orleans in German Literature". In: The Modern Language Review, Vol. 22, No. 3. (Jul., 1927), pp. 298-309.

BOUZY, Olivier. "Manuscrits inutiles et auteurs inconnus : la transmission du souvenir de Jeanne d'Arc du XVe au XVIIIe siècle", Bulletin des Amis du Centre Jeanne d'Arc, $n^{\circ} 26,2002$, p. 23-52 .

BOUZY, Olivier, CONTAMINE, Philippe. \& HÉLARY, Xavier. Jeanne d'Arc : Histoire et dictionnaire. Bouquins, 2012.

CARBONELL, Charles Olivier. "Guizot homme d'Étar et le mouvement historiographique français du XIXe siécle”. Actes du Colloque Guizot. 1974. Paris, 1976. P. 239-272.

CARLYLE. Les héros. Maisnoneuve et Larose, 1998.

CARON, Jean-Claude. "Jules Michelet, Correspondance générale. Tome X : 18621865, Textes réunis, classés et annotés par Louis Le Guillou". Paris, Honoré Champion, 1999. Revue d'histoire du XIXe siècle, 1999-19, Aspects de la production culturelle au XIXe siècle, [En ligne], mis en ligne le 26 août 2008. URL : http://rh19.revues.org/document164.html. Consulté le 17 octobre 2008.

CARON, Jean-Claude. "Un siècle de science et de militance: pour une histoire savante et engage". Revue d'histoire du XIXe siècle, 2005-31. La "Société de 48" a cent ans, [En ligne], mis en ligne le 18 février 2006. URL: http://rh19.revues.org/document940.html. Consulté le 17 octobre 2008.

CHASE JR., Richard. "Jules Michelet and the Nineteenth-Century Concept of Insanity: A Romantic's Reinterpretation". In: French Historical Studies, Vol. 17, No. 3. (Spring, 1992), pp. 725-746. 
CLAUDEL, P. Joana d'Arc entre as chamas. Rio de Janeiro: Agir, 1963.

CLARK, Linda L. "Approaching the History of modern French Education. Recent surveys and research guides". In: French historical studies. 15/1. Pritemps, 1987. P. 157-166.

CLUZEL, Jean. Jeanne d'Arc. La politique par d'autres moyens. Economica, 2006.

. "Wallon, Jeanne d'Arc et la République". [on line] Séance en hommage à Alexandre-Henri Wallon. Académie des sciences morales et politiques. Paris, 2004. Disponível em: http://www.asmp.fr/travaux/exceptionnelles/cluzel_wallon.pdf. Consultado em 25/03/2008.

CONTAMINE, Phillipe. "L'action et la persone de Jeanne d'Arc. Remarque sur l'attitude des princes français à son egard". In: Bulletin de La Societé Historique de Compiégne. 28. 1982. P. 63-80.

- De Jeanne d'Ac aux guerres d'Italie. Figures, images et problèmes du XVe siécle. Orléans: Paradigme, 1994.

- 'Naissance d'historiogaphie. Le souvenir de Jeanne d'Arc en France et hors de France depuis le 'procés de son innocence' jusqu'au début du XVIe siècle". In: Francia 15, 1987.

COORNAERT, E. Les destins de Clio em France depuis 1800. Paris, 1977.

CROSSLEY, Ceri. French historians and romanticism : Thierry, Guizot, the SaintSimonians, Quinet, Michelet. London; New York : Routledge, 1993.

COUSIN, Victor. Du vrai, du beau et du bien. Paris, Didier, 1881.

COUSIN, Victor. Introduction à l'histoire de la philosophie. 1828. 
DE LASTEYRE, Robert. "Notice sur la vie et les travaux de Jules Quicherat". In: QUICHERTAT, Jules. Mélange d'archeologie et d'histoire. 2 t. Paris, 1885.

DIGEON, Claude. La crise allemand de la pensée française. 1870-1914. Paris, 1959.

DONCTUR, P. Le mystère de la passion de Jeanne d'Arc. Paris: L'Orante, 1948.

DOSSE, François. A história à prova do tempo: da história em migalhas ao resgate do sentido. São Paulo : Editora da Unesp, 2001.

O desafio biográfico - escrever uma vida. São Paulo: Edusp, 2009.

DUPARC, Pierre. "Le troisième procès de Jeanne d'Arc". In: Comptes-rendus des séances de l'Académie des Inscriptions et Belles-Lettres, 122e année, N. 1, 1978. pp. $28-41$.

FABRE, Daniel. L'atelier des héros. In: CENTILIVRES, Pierre; FABRE, Daniel;

ZONABEND, Françoise (orgs.). La fabrique des héros. Paris: Éditions de la Mason des sciences de l'homme, 1998.

FEBVRE, Lucien. Michelet e a Renascença. São Paulo: Scritta, 1995.

FONTANA, J. A história dos homens. Bauru: Edusc, 2004.

FRAIOLI, D. "The literary image of Joan of Arc: Prior influences". Speculum, Vol. 56, n. 4 (Oct., 1981), pp. 811-830.

FUETER, E. Histoire de l'historiographie moderne. Félix Alcan: Paris, 1914.

FURET, François. A Revolução em debate. Bauru: Edusc, 2001. Galimard. 1984.

“Ancien Régime”. In: NORA, Pierre. Les lieux de mémoire. Paris: 
Pensar a Revolução Francesa. Edições 70, 1998.

. L'atelier de l'histoire. Paris: Flamarion, 1981.

FRAZIER, Françoise. Histoire et morale dans le Vies Parallèles de Plutarque. Paris: Les Belles Lettres, 1996.

GARCIA, P. et AL. Les courants historiques en France. XIXe-XXe siècle. Paris: Armand Colin, 2005.

GAUCHET, M. "Les" Lettres sur l'histoire de France" d'Augustin Thierry. L'alliance austere du patriotism et de la science". In: NORA, Pierre. Les lieux de mémoire. Paris: Galimard. 1984. P. 787-850.

GEARY, Patrick. O mito das nações. A invenção do Nacionalismo. São Paulo: Conrad Editora, 2005.

GELLNER, Ernest. Encuentros con el nacionalismo. Alianza, 1985.

Nacionalismo e democracia. Brasília : Universidade de Brasília.

1981.

GERARD, Alice. La révolution française. Mythes et interpretations. Paris, 1970.

GINSBURG, J. O Romantismo (org.) São Paulo: Perspectiva, 2005.

GUERREAU, Alain. "Política / Derecho / Economía / Religión: ¿Cómo eliminar el obstáculo?" In: DE TOGNERY, Reyna Pastor (org.). Relaciones de poder, de producción y de parentesco en la Edad Media y Moderna: aproximación a su estudio. Madri: Consejo Superior de Investigaciones Científicas, 1990. p.459-465.

GRAFTON, Anthony. As origens trágicas da erudição. Campinas: Papirus, 1998. 
GREW, R. ; HARRIGAN, P. / WHITNEY, J. “La scolarisation en France”. In: Annales. ESC. 39. 1984. P. 117-158.

GOYAN, G. "Jeanne d'Arc devant la opinion allemande". In: Mémoires de la Societé Archeologique et Historique de l'Orléanais. 31. 1907. P. 1-36.

GRUNER, Shirley. "Political historiography in Restoration France". In: History and Theory. 8. 1969. P. 346-365.

GUIBERT, Pierre. Histoire mythologique des Français. Paris, 1976.

GUILLEMIN, Henri. Jeanne, dit Jeanne d'Arc. Paris, 1970.

Guia Visual Folha de São Paulo - França. São Paulo: Publifolha, 2009

GURY, Jacques. "L'historien et les mythes de Jeanne d'Arc des Lumières au Romantisme”. In: Jeanne d'Arc. Une époque, um rayonnement. Colloque d'histoire médiévale. Orléans, 1979.

HARTOG, F. Le XIXe siècle et l'histoire. Le cas Fustel de Coulanges, Paris: Presses Universitaires de France, 1988.

HEIMANN, Nora. "The art of politics in Early Nineteenth Century France: E. -É. - F. Gois's Jeanne d'Arc pendant le combat as a metaphor." In: Gazette des Beaux-Arts. T. CXXXII - 1554-55e livraisons. 1998. P. 29-46.

HERMET, Guy. História das nações e do nacionalismo na Europa. Lisboa: Estampa, 1997.

HOBSBAWN, Eric J \& RANGER, Terence (orgs.) A invenção das tradições. Rio de Janeiro: Paz e Terra, 1984.

Rio de Janeiro : Paz e Terra, 1991.

Nações e nacionalismo desde 1780: programa, mito e realidade. 
HOFFMAN, Stanley. Essai sur La France. Déclin ou renouveau? Paris, 1974.

Sur La France. Paris, 1976.

HUGO, V. Guerre aux démolisseurs! Artigo inicialmente publicado em 1829 na Revue de Paris e republicado em 1832 na Revue des deux mondes, t. V. Nossa Senhora de Paris. Porto: Lelo, 1952.

HUPPERTE, George. L'ídeé de l'histoire parfeite. Paris, 1972.

JARDIN, A. e A-J TUDESCQ. La France des notables. 1815-1848. Paris, 1973.

JAURÉS, Jean. Histoire socialiste de la Révolution Française. Paris.1968.

JEANEÉ, Egide. L'image de la Pucelle dans la littérature historique française depuis Voltaire. Paris, 1935.

JENNINGS, E. "Reinventing Jeanne': the iconology of Joan of Arc in Vichy Schollbooks, 1940-44". Journal of contemporary History, vol. 29, n. 4. (Oct., 1994), pp. 711-734.

JOHNSON, Mary-Elisabeth. Michelet et le christianisme . Paris : Nizet, 1951.

JOHNSON, Douglas. "The two Frances: the historical debate". In: WRIGHT, Vincent (ed.). Conflict and Consensus in France. Londres, 1979. P. 3-10.

JOUIN, Henri."La fête de Jeanne d'Arc“. In: Jehanne, La Pucelle. 2. 1911.

JULLIAN, Camille. Extraits des historiens français du XIXe siécle. Genéve, 1977.

KEYLOR, Willian R. Academy and Community. The foundation of the French Historical Profession. Cambridge, 1975. 
KRUMEICH, Gerd. Armaments and Politics in France on the eve of the first World War. Leamington, 1985.

. "Controverses historiographiques autour de la mission de Jeanne

d'Arc au XIXe siècle", Bulletin des Amis du Centre Jeanne d'Arc, n 10, 1986, p. 33-40.

. Jeanne d'Arc à travers l'histoire. Albin Michel, 1993.

. "Jeanne d'Arc dans les encyclopedies françaises du XIXe siécle".

Bulletin de l'Association des amis du centre Jeanne d'Arc, n. 5, 1982.

Jeanne d'Arc dans l'Histoires de France ao XIXe siécle.

Conference dactylographiée. Institut philosophique allemand, 1982.

KRUMEICH, Gerd. Jeanne d'Arc. Geschichte der Jungfrau von Orleans (= C.H. Beck Wissen; 2396), München: C.H.Beck 2006.

KSELMAN, Thomas A. Miracles and prophecies in Nineteenth Century France. Brunswick, 1983.

LANERY D'ARC, Pierre. Le livre d'or de Jeanne d'Arc. Bibliographie raisonnée et analytique. Paris, 1894.

LAVISSE, E. "L'enseignement historique en Sorbonne et l'éducation nationale". In: Revue des deux mondes. 49. 1882. P. 870-897.

LE POTTIER, Jean. Histoire et erudition. Recherches et documents sur l'histoire et le rôle de l'érudition médiévale dans la historiographie française au XIXe siécle. Tese. École des Chartres, 1979.

LEDUC, Jean. "Quelques aspects de l'écriture du temps chez les historiens français de la seconde moitié du XX ${ }^{\mathrm{e}}$ siècle“", Revue d'histoire du XIXe siècle, 2002-25, Le temps et 
les historiens, $[\mathrm{En}$ ligne], mis en ligne le 7 mars 2008. URL: http://rh19.revues.org/document416.html. Consulté le 17 octobre 2008.

LEFEBVRE, Georges. La naissance de l'historiographie moderne. Paris, 1971.

LENIAUD, J. M. "O patrimônio recuperado. O exemplo de Saint-Denis.” In: RIOUX, J- P e SIRINELLI, J-F. Para uma história cultural. Lisboa: Estampa, 1998. p. 335-348.

LIGTHBODY, Charles W. The judgements of Joan. Joan of Arc. A study in cultural history. Cambridge, 1961.

MAROT, Pierre. "De la réhabilitation à la glorifiction de Jeanne d'Arc. Essai sur le culte de l'heroine en France pendante cinq siècles". In: Mémorial Du Ve centenaire de la réhabilitation de Jeanne d'Arc. Paris, 1958.

MARSAN, Jules. La bataille romantique. Paris, 1912.

MARTIN, Philippe (org). Jeanne d'Arc: les métamorphoses d'une hérö̈ne. Place Stanislas, 2009.

MAURAIN, J. La politique ecclésiastique du Second Empire. Paris, 1930.

MAURICE, J. \& COUTY, D. Images de Jeanne d'Arc. Actes du colloque de Rouen. Presses Universitaires de France: Paris, 2000.

MAUROIS, A. Aspects de la biographie. Grasset, 1932.

McMILLAN, J. "Clericals, anticlericals and the women's movement in France under the Third Republic". The Historical Journal, Vol. 24, n. 2 , (Jun., 1981), pp. 361-376.

MEE, J \& Keymer, orgs. The Cambridge companion to english literature: 1740-1830. Cambridge University Press, 2004. 
Mgr. BRUN. "La fête de la délivrance de la ville à la veille de la grande Révolution". In: Bulletin de l'association des amis du Centre Jeanne d'Arc. 5. Fev. 1982, p. 30-43.

MICHAUD-FRÉJAVILLE, Françoise. "Autour du bûcher de Jeanne". In: Cahiers de recherches médiévales et humanistes [Em ligne], 3. 1997, mis en ligne le 06 août 2008. URL : http://crm.revues.org/2473. 2002, p. 3-18.

France au XVIIe siècle." In : Jeanne d'Arc en garde à vue, sous la direction de Dominique Goy-Blanquet, Bruxelles, 1999, p. 55-77.

MICHAUD-FRÉJAVILLE, Françoise. "Le «médiévalisme » de la Jeanne d'Arc de Péguy (1897)". Cahiers de Recherches Médiévales (XIIe-XVe s.), 12spé, 2005. p. 273283. MIQUEL, Pierre. Lettre ouvert aux bradeurs de l'histoire. Paris, 1981.

MORSEL, Joseph. L'Histoire (du Moyen Âge) est un sport de combat... réflexions sur les finalités de l'histoire du moyen âge destinées à une société dans laquelle même les étudiants d'histoire s'interrogent. LAMOP - PARIS I. 2007. Disponível em: http://lamop.univ-paris1.fr/IMG/pdf/SportdecombatMac.pdf. Acesso: agosto de 2009.

MUSSET, A. La confession d'un enfant du siècle. Paris: Charpentier, 1867.

NETTEMENT, A. "La mission de Jeanne d'Arc". In: Revue des questions historiques. Oc. 1866. p. 526-561.

NORA, Pierre. Les lieux de mémoire. Paris: Galimard. 1984. (3 volumes.)

OLIVEIRA, Claire C. "Ser sóbrio e racional: os usos ambíguos da razão na literatura dietética dos primórdios das luzes inglesas". In: Scientiae Studia.. vol.4 no.1 São Paulo Jan./Mar. 2006. Disponível em: http://www.scielo.br/scielo.php?pid=S1678$\underline{31662006000100004 \& \text { script=sci arttext. Acesso: } 23 / 10 / 2011 .}$

PAVIÉ, R. A propos de la beatification de Jeanne d'Arc. 1914.

PERNOUD, Régine. Jeanne d'Arc. Paris, 1959. 
$\overline{\text { Jeanne d'Arc. } 1983 .}$.

"La Jeanne". In: Bulletin de l'Association des amis du Centre

PLUTARCO. Vies paraléles. I. Garnier-Flamarion, 1995.

POCOCK, J. G. A. "Edward Gibbon in History: Aspects of the Text in The History of the Decline and Fall of the Roman Empire". THE TANNER LECTURES ON HUMAN VALUES. Delivered at Yale University March 1-3, 1989.

POIDEVIN, Raymond \& BARIÉTY, Jacques. Les relations franco-allemands. 1815 1975. Paris, 1977.

RAKNEM, Ingvald. Joan of Arc in History. Legend and literature. Oslo, 1971.

REARIC, Charles. "Henri Martin: from druidic traditions to republican politics". In: LAQUEUR, Walter \& MOSSE, G.W. L. Historians and politics. Londres, 1974.

REICHEL, Peter. "Les guerres franco-françaises". In: Vingtiéme siècle. Revue d'histoire. 5. (1985).

REIZOV, B. L'historiographie romantique française. (1815-1830) Moscou, 1963.

RIBERA-PERVILLÉ, Cl. "Jeanne d'Arc au pays des images". In: L'Histoire, 15. Set.1979.

RIGNOL, Loïc. "Augustin Thierry et la politique de l'histoire. Genèse et principes d'un système de pensée.", Revue d'histoire du XIXe siècle, 2002-25, Le temps et les historiens , [En ligne], mis en ligne le 29 juin 2005. URL : http://rh19.revues.org/document423.html. Consulté le 17 octobre 2008.

RIGOLET, Yann. “De la messagère de Dieu à Marianne". In: Religions \& Histoire $\mathrm{n}^{\circ}$ 25, 2009. Page : 51-53.

RIOT-SARCEY, Michèle. "Comment relire le XIX siècle ? La Revue d'histoire du XIX ${ }^{e}$ siècle au milieu du gué", Revue d'histoire du XIXe siècle, 2005-31, La "Société de 
48" a cent ans, [En ligne], mis en ligne le 18 février 2006. URL : http://rh19.revues.org/document950.html. Consulté le 17 octobre 2008.

ROBB, Graham. A Descoberta da França - uma jornada histórico geográfica da Revolução à Primeira Guerra Mundial. Rio de Janeiro: Record, 2007.

ROUSSEAU, J-J. A origem da Desigualdade entre os homens. São Paulo: Escala, 2007.

RUDLER, G. Michelet : historien de Jeanne d'Arc. Paris : PUF, 1925.

SANSON, R. "La fête de Jeanne d'Arc en 1894, controverse et célébration". Revue d'Histoire moderne et contemporaine, 20 (1973), p. 444-463.

SARAMAN, Charles. "Le centenaire de notre revue. La Bibliotéque de l'École des Chartes depuis un siécle“. In: Bibliotéque de Chartes 100. 1939. P. 237-280.

SCHNEIDER, E. Jeanne d'Arc et ses lys: la légende et l'histoire. Paris : Grasset, 1952.

SEGAL, Lester A. "Nicolas Lenglet Du Fresnoy: Tradition and change in French Historiographical thought on the early Eighteenth Century". In: Studies on Voltaire and the eighteenth Century. 98. 1972. p. 69-117.

SCHMITT, Jean-Claude e OEXLE, Otto-Gerhard. [Dir.], Tendances (Les) actuelles de l'histoire du Moyen Âge en France et en Allemagne. Paris: Publications de la Sorbone, 2003.

SNIPES-HOYT, Carolyn. "Jeanne d'Arc Visits Paris in 1912: Dramatis personae and Personification”. In: The French Review, Vol. 73, No. 6. (May, 2000), pp. 1141-1154.

STERNBACH, R. "Coleridge, Joan of Arc and the Idea of Progress". ELH, Vol. 46, n. 2 (Summer, 1979), pp. 248-261.

STERNHELL, Zeev. Maurice Barrés et le nationalism français. Paris, 1972. 
TEUTEBERG, René. Prosper de Barante. 1782-1866. Ein Romantisher Historiker des Liberalismus. Bâle, 1945.

THICKETT, Dorothy. Estienne Pasquier (1529-1615). The versatile Barrister of the $16^{\text {th }}$ century. Londres, 1979.

THIESSE, Anne-Marie. La création des identités nationales. Editions du Seuil, 2001.

VERCRUYSSE, Jeroom. Jeanne d'Arc au Siècle des Lumières. In: Studies on Voltaire and the Eighteenth Century. 90. 1972. P. 1659-1729.

La Pucelle d'Orléans. Oxford, 1970.

VERGNAUD-ROMAGNESE. Mémoires et documents curieux inédites sur les anciens et sur les nouveaux monuments eleves à la mémoire de Jeanne d'Arc. Paris, 1862.

VOLTAIRE. Dictionaire Philosophique. Cosse et Gaultier-Laguionie, 1838.

VIALLANEIX, Paul. "La Jeanne d'Arc de Jules Michelet, légende romantique". In: Travaux de linguistique et de literature, $\mathrm{t}$. XVII, $\mathrm{n}^{\mathrm{o}} 2$, Études litteraires. Strasbourg. 1979, p. 05-114.

Flamarion, 1971.

La voie royale. Essai sur le peuple chez Michelet. Paris:

VLASSOPOULOS, K. Unthinking the Greek polis. Ancient Greek History beyond Eurocentrism. Cambridge University Press, 2007.

WAQUET, Françoise. Les fêtes royales sous la Restauration. Paris, 1982.

WARNER, Marina. Joan of Arc. The image of female heroism. New York: Alfred A. Knopf, 1981. 
WELLWEK, René. “The concept of romanticism”. In: Comparative literature. 1. 1949.

WHITE, Hyden. Meta-história. A imaginação histórica do século XIX. São Paulo: Edusp: 1995.

WILLIAMS, R. Palavras-Chave. Um Vocabulário de Cultura e Sociedade. São Paulo: Boitempo Editorial, 2007. 